\title{
THE UNITED STATES GEOLOGICAL SURVEY
}

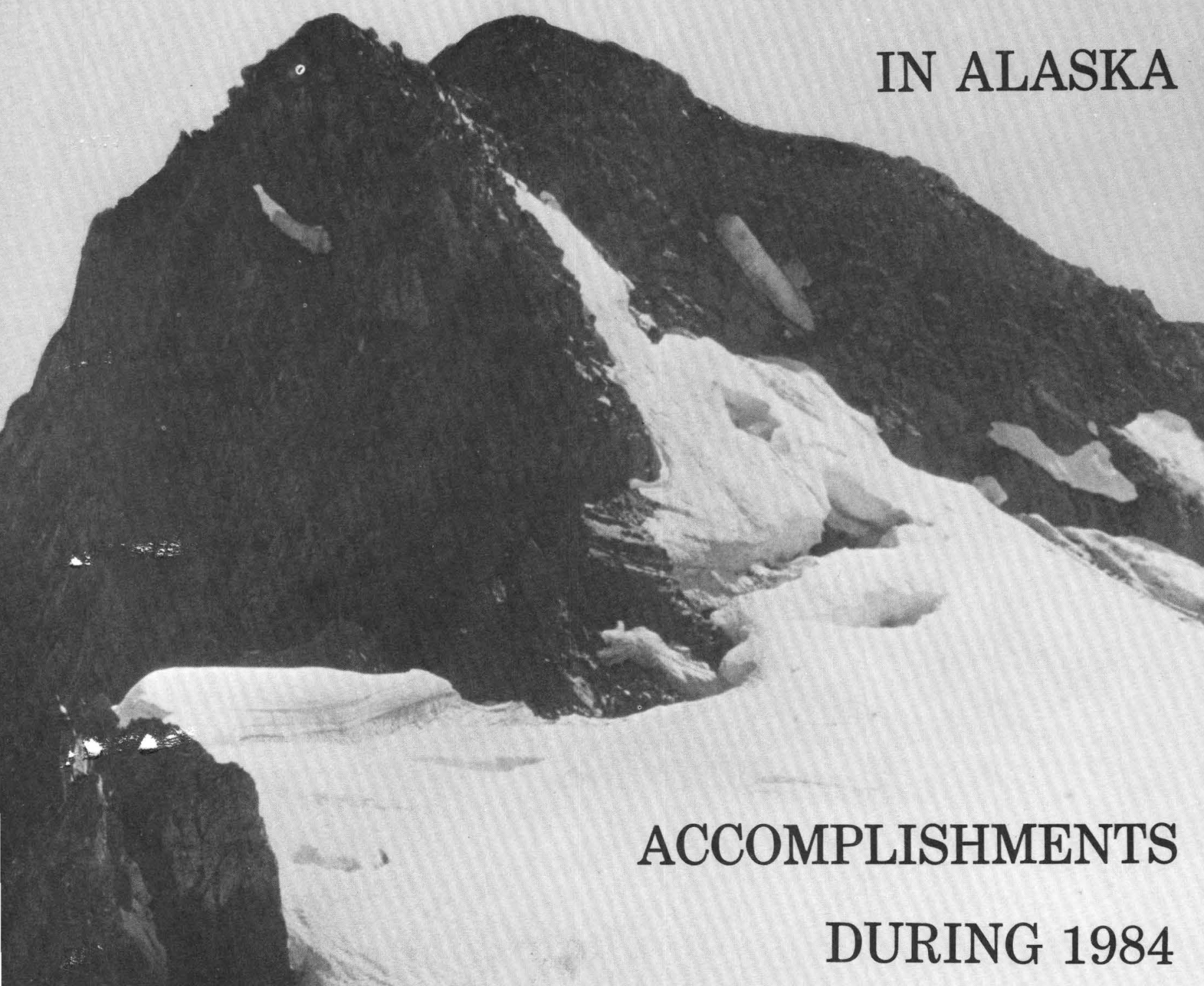

U. S. GEOLOGICAL SURVEY CIRCULAR 967

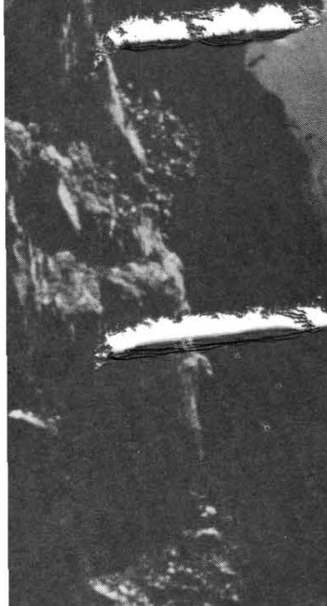




\section{Front Cover}

-Evaluating exposures on Divider Mountain near the crest of the Chugach Mountains in southern Alaska for the Trans-Alaska Crustal Transect (TACT) project. TACT is a geological and geophysical study to examine crustal features along the route of the TransAlaska oil pipeline. The transect extends from the tectonically active convergent margin in the Gulf of Alaska to the passive trailing margin of arctic Alaska near Prudhoe Bay. In 1984, detailed geologic mapping was conducted and seismic refraction lines were established near the southern end of the corridor in the Chugach Mountains and the southern Copper River basin. Articles by Fuis, Ambos, Mooney, Page, and Campbell (p. 56), and Plafker, Nokleberg, and Lull (p. 76), report preliminary findings of this project. 


\title{
THE \\ UNITED STATES GEOLOGICAL SURVEY \\ IN ALASKA:
}

\section{ACCOMPLISHMENTS DURING 1984}

\author{
Susan Bartsch-Winkler, \\ Editor
}

U.S. Geological Survey Circular 967

SHORT PAPERS DESCRIBING RESULTS OF

RECENT GEOLOGICAL INVESTIGATIONS 


\section{DEPARTMENT OF THE INTERIOR DONALD PAUL HODEL, Secretary \\ U.S. GEOLOGICAL SURVEY \\ Dallas L. Peck, Director}

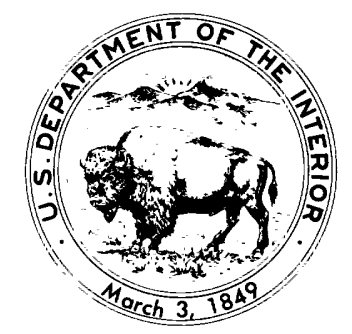

Library of Congress Catalog Card Number 76-608093

Free on application to Distribution Branch, Text Products Section, U.S. Geological Survey, 604 South Pickett Street, Alexandria, VA 22304 


\section{CONTENTS}

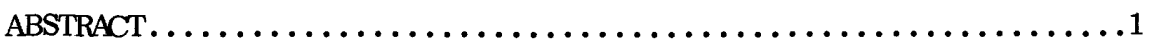

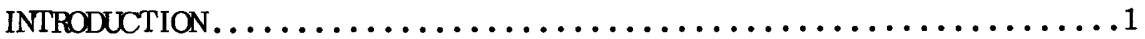

NORTHERN ALASKA

Gravity lows may indicate Pleistocene deposits beneath Glacial Lake Noatak,

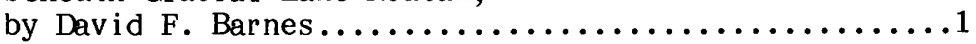

Use of stream-sediment insoluble residues in geochemical exploration for carbonate-hosted mineral deposits in the Baird Mountains, by Peter F. Folger, Richard J. Goldfarb, Elizabeth A. Bailey, Ri chard M. O'Leary, and Stephen J. Sut ley........................

Selected anomalous rock and sediment samples from central and northwestern Baird Mountains quadrangle, by Susan M. Kar 1, Jean ine M. Schmidt, and

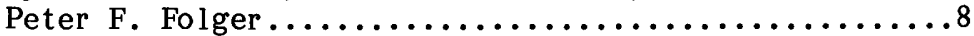

Ophiolitic ultramafic rocks of the Jade MountainsCosmos Hills area, southwestern Brooks Range, by Robert A. Loney and Glen R. Himmelberg...........13

Sedimentology of meandering-stream cycles, upper part of the Ear Peak Member of the Kanayut Conglamerate, central Brooks Range, by Thomas E. Moore and Tor H. Nilsen.............15

\section{WEST-CENTRAL ALASKA}

Greenschist-facies metamorphic rocks of the northcentral Iditarod quadrangle, by Linda M. Angeloni and Marti L. Miller..........19

Early Cretaceous evolution of the northeastern Yukon-Koyukuk Basin, west-central Alaska, by Stephen E. Box, William W. Patton, Jr.,

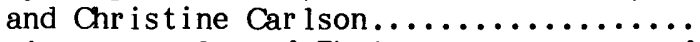

Preliminary results of $\mathrm{Pb}$-i sotope analyses of deposits from the Seward Peninsula, by Stanley E. Church, Joseph A. Briskey, Maryse H. Delevaux, and Anne P. LeHuray...........24

Preliminary study of lode gold deposits, Seward Peninsula, by Bruce M. Gamble, Roger P. Ashley, and

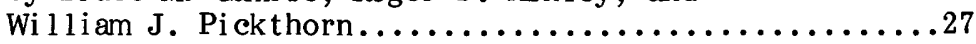

\section{EAST-CENTRAL ALASKA}

Preliminary study of shear sense in mylonites, eastern Ray Mountains, Tanana quadrangle, by Ronny $\mathrm{T}$. Mi yaoka and James H. Dover 
SOUTHWESTERN ALASKA

Terrane analysis, northern Bristol Bay region, southwestern Alaska,

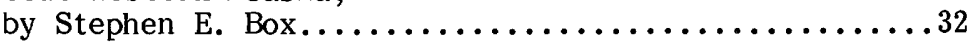

Geologic setting of high-pressure metamorphic rocks, Cape Newenham area, southwestern Alaska, by Stephen E. Box...........................

Late Quaternary glaciation of the Pavlof Bay and Port Moller areas, Alaska Peninsula, by Florence R. Weber ...................... 42

SOUTHERN ALASKA

Age of Devonian igneous-arc terranes in the northern Mount Hayes quadrangle, eastern Alaska Range by John N. Aleinikoff and Warren J. Nokleberg.......44

Reconnaissance hydrology and suspended sediment analysis, Turnaga in Arm estuary, Upper Cook Inlet, by Susan Bartsch-Winkler, Ri chard P. Emanue 1, and Gary R. Winkler......................... 49

Gravity and magnetic model of part of the 1984 TACT line, Chugach Mountains and southern Copper River basin, by David L. Campbell and David F. Barnes..........52

Bedrock mapping of remote areas using medial moraine debris from active glaciers, Mount Hayes and Healy quadrangles, by Edward B. Evenson, George C. Stephens, and

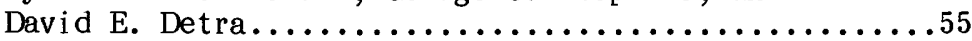

Preliminary results of TACT 1984 seismic-refraction survey of southern Alaska, by Gary S. Fuis, Elizabeth L. Ambos, Walter D. Mooney, Robert A. Page, and David L. Campbe11.......56

Paleomagnetism of sedimentary rocks in the Prince William and Yakutat terranes, by John W. Hi llhouse and C. Sherman Gromme........660

New evidence for activity of the Talkeetna segment of the Castle Mountain-Caribou fault system-The 1984 Sutton earthquake, by John C. Lahr, Robert A. Page, Kent A. Fogleman, and $\mathrm{Ch}$ is topher D. Stephens ...................62

Preliminary interpretation of factor analysis of geochemical data from the Healy quadrangle, by Thomas $\mathrm{D}$. Light.......................... 64

Sumary of stratigraphy, structure, and metamorphism of Devonian igneous-arc terranes, northeastern Mount Hayes quadrangle, eastern Alaska Range, by Warren J. Nokleberg and John N. Aleinikoff.......66

Early Pennsylvanian conodonts from the Strelna Formation, Chitina Valley area, by George Plafker, Anita G. Harris, and Kather ine M. Reed.........................71 
SOUTHERN ALASKA (cont inued) Page

Summary of data on the age of the Orca Group, by George Plafker, Gerta Keller, Steven W.

Nelson, Julie A. Dumoulin, and Marti L. Miller......74

Summary of the 1984 TACT geologic studies in the nor thern Chugach Mountains and southern

Copper River basin, by George Plafker, Warren J. Nokleberg, and John S. Lull............................. 76

Seismicity in southern Alaska, October 1983September 1984, by Chr istopher D. Stephens, Kent A. Fog leman, John C. Lahr, and Robert A. Page................79

\section{SOUTHEASTERN ALASKA}

Southeastern Alaska coincident zone, by David A. Brew and Arthur B. Ford............. 82

Fossiliferous Middle and(or) Upper Triassic rocks within the Coast plutonic-metamorphic complex southeast of Skagway, by David A. Brew, Arthur B. Ford,

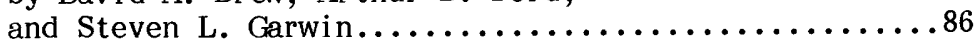

Polymetamorphism in the eastern Petersburg quadrangle, by Susan L. Douglass and David A. Brew........... 89

Ultramafic bodies in the Coast plutonic-metamorphic complex near Skagway, by Glen R. Himmelberg, David A. Brew, and

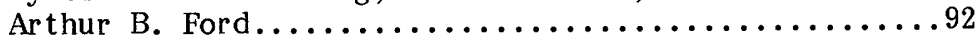

LISTING OF REFERENCES BY SUBJHCT MATTER. ..............93

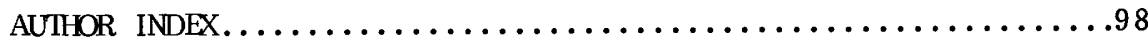

\section{ILLUSTRATIONS}

Page

Figure 1. Map showing regions of Alaska used in this circular.......2

2. Map showing areas in northern Alaska discussed in this

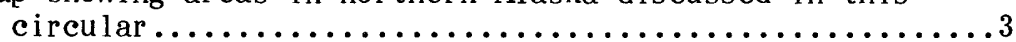

3. Relation between Bouguer gravity data contours, the major present $\mathrm{river}$ drainage system, the Pleistocene (Itkillik glaciation) extent of Lake Noatak, former lake outlet channels, and the major Itkillik valley

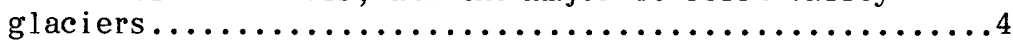

4. Schematic index mao showing approximate locations of the three drainage areas within the Baird Mountains

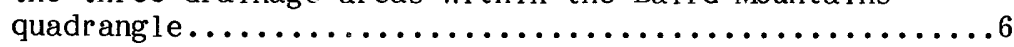

5. Schematic diagram of drainages and sample sites for the three study areas shown in figure $4 \ldots \ldots \ldots \ldots \ldots \ldots$ 


\section{ILLUSTRATIONS--continued}

Figure 6. Comparison of results of analyses on very fine sand samples that have been leached (insoluble residue samples--solid line) with samples that have been left untreated (dashed line) from the Omar drainage.....7

7. Comparison of results of analyses on very fine sand samples that have been leached (solid line) with untreated samples (dashed line) from the Frost drainage....7

8. Area of anomalous samples in the central and northwestern portions of the Baird Mountains quadrangle, and locations of figures 9 and $10 \ldots \ldots \ldots \ldots \ldots \ldots$

9. Location of anomalous rock and stream sediment samples in the central Baird Mountains quadrangle...........11

10. Location of anomalous rock and stream sediment samples in the northwestern Baird Mountains quadrangle....11

11. Generalized geology of the Jade Mountains-Cosmos Hills area, modified from Patton and others (1968).....14

12. Measured sections in the upper part of the Ear Peak Member of the Kanayut Conglomerate and index map (inset), west of the Itkillik River, Chandler Lake A-1 quadrangle...........................

13. Aerial photograph looking west of measured sections $\mathrm{A}, \mathrm{B}, \mathrm{C}, \mathrm{D}$, and $\mathrm{E}$ west of the Itkillik River. Abbreviations: Dkep, Ear Peak Member, Kanayut Conglamerate; Dks 1, Sha in in Lake Member, Kanayut Conglomerate.........18

14. Map showing areas in west-central Alaska discussed in this circular................................ 19

15. Schematic geologic map of the central Ophir and

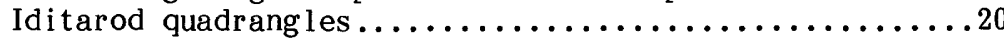

16. Generalized map of Lower and middle Cretaceous rocks of the Yukon-Koyukuk basin (with locations of two stratigraphic sections shown in fig. 17); concurrent uplift of the schistose Brookian orogenic belt is suggested by predominance of Early Cretaceous K-Ar cooling ages from metamorphic rocks....................

17. Generalized stratigraphic sections from northeastern Yukon-Koyukuk basin; correlation between sections is based on abrupt upward disappearance of distinctive potassium feldspar-rich tuff beds in each section......22

18. Trace element data from Neocomi an basalts $\left(\mathrm{SiO}_{2}=53 \%\right.$; CaO+MgO $=11-20 \%$ ) from Hughes Creek area, plotted on three discriminant diagrams of Pearce and Cann

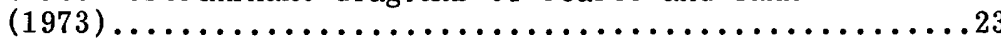

19. Localities of samples discussed in this study: R, Red Dog; D, Drenchwater Creek; H, Hannum Creek; L, Lost Ri ver Mine; W, Wheeler; I, Independence Mine; P,

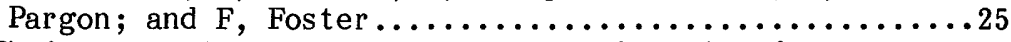

20. $\mathrm{Pb}$ isotope diagram showing the relationship of various deposits. The SEDEX growth curve, der ived from the deposits of the Selwyn Basin (Godwin and Sinclair, 1982), the growth curve of Stacey and Kramers (1975), and the mid-ocean ridge line (MORB) are shown for reference. The range of $\mathrm{Pb}$-isotopic data from SEDEX-type deposits from the Selwyn Basin (Godwin and Sinclair, 1982) is shown by the stip-

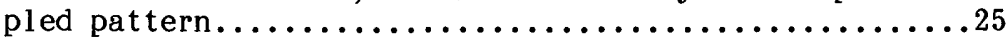




\section{ILLUSTRATIONS--continued}

Figure 21. Distribution of lode gold occurrences (circles), placer gold regions (line pattern) and Nome Group rocks (dot pattern) on the Seward Peninsula. Numbers indicate lodes discussed in text: 1, Koyana Creek; 2, Bluff; 3, Big Hurrah; 4, Sliscovitch; 5, McDuffee; 6, California; 7, Stipec \& Kotovic, and Sophie

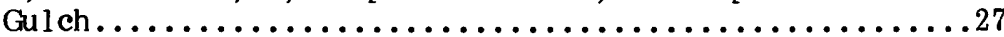

22. Map showing areas in east-central Alaska discussed in

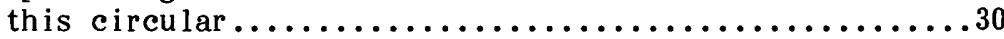

23. Geology of the eastern Ray Mountains area, showing

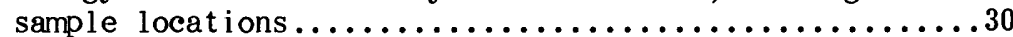

24. Sketches of thin section observations illustrating criteria, and depicting sinistral shear. The number of observations for each shear sense is denoted........31

25. Sketch of sample 28c showing stretching lineation, strike and dip of mylonitic foliation, and lines (marked $\mathrm{x}$ and $\mathrm{y}$ ) drawn to indicate where thin sections were to be cut. Only the sections cut parallel to the stretching lineation (y sections) were studied

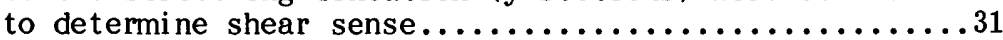

26. Map showing areas in southwestern Alaska discussed

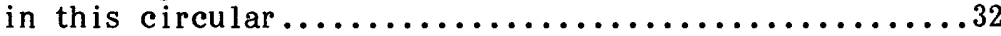

27. Terranes and subterranes of the northern Bristol Bay region of southwestern Alaska (modified from Jones

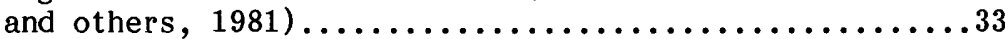

28. Stratigraphic columns of terranes and subterranes shown in figure 27. Timing of terrane linkages shown by bold horizontal lines; numbers keyed to table 8 . (Geologic time scale from Palmer, 1983.)..............34

29. Generalized geologic map and cross sections of the Cape Newenham region, southwestern Alaska (modified fram Box, 1985a). High pressure metamorphic minerals are known only from the Cape Peirce-Security Cove exposure of the Cape Peirce subterrane...........38

30. Equal area steronet plots of schistose rocks of the the Cape Peirce subterrane (unit 2) of the Goodnews terrane. (A), $\mathrm{D}_{2}$ lineations from Cape PeirceSecurity Cove window. Separation of fold axes of opposite asymmetries across N. $18^{\circ}$ E. line suggests rotation of fold axes into transport direction during overthrusting. (B), Poles to $D_{3}$ crenulation cleavage from Osviak River window, with arrows indicating vergence direction of erenulation microfolds. Inset illustrates conjugate relationship and inferred compressive stress direction........41

31. Extent and possible correlation of glacial moraines in the Pavlof Bay-Port Moller area................43

32. Map showing areas in southern Alaska discussed in this circular ................................45

33. Concordia plots of U-Pb data from zircons from metaigneous rocks in the northern Mount Hayes quadrangle, eastern Alaska Range (A), Metaigneous rocks in the Macomb, Jarvis Creek Glacier, and Hayes Glacier terranes. (B), Metarhyolite samples (81ANK233A and 82ANK031A) from the Jarvis Creek Glacier terrane.......47 


\section{ILLUSTRATIONS--continued}

Figure 34. Index map of Turnaga in Arm showing the Anchorage tidal station location, current measurement site of the Alaska Department of Highways (1969), and tide observation, water level, and suspended sediment

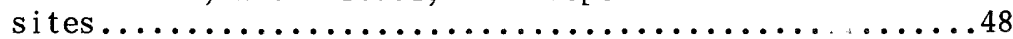

35. Plot of water level height versus time at sample

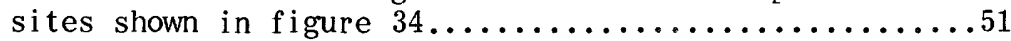

36. Measurements of specific conductance taken throughout the tidal cycle at various sites st on in

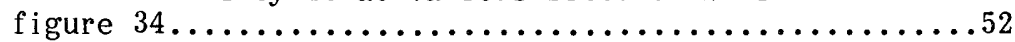

37. Gravity and magnetic models of possible bodies in the Chugach Mountains and souther ${ }^{\circ}$ Copper River basin along the southern part of the 1984 TACT line..........53

38. Index map of southern Alaska showing locat ion of terranes (Chugach, Peninsular, and Wrangellia) and

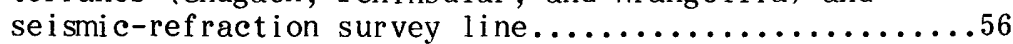

39. Seismic refraction data from the Chugach line. (A), Record section for shot point 20 (SP20) with travel-time curves superimposed indicating reflected (dashed) and refracted (solid) arrivals. Amplitudes are normalized trace by trace; reducing velocity is $6 \mathrm{~km} / \mathrm{sec}$. (B), One-dimensi onal P-velocity-depth

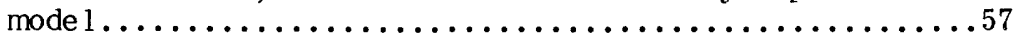

40. Tutorial model of arrivals associated with a lowvelocity zone. (A), Hypothet ical travel-time curve. (B), Hypothetical model wi th low-velocity

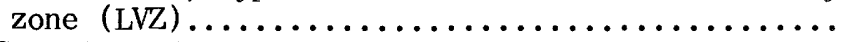

41. Seismic refraction data from the South Richardson line. (A), Record section for shot point 8 and

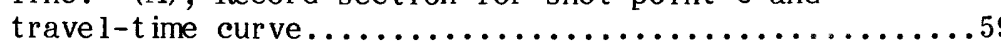

42. Geologic map of the study area (modified from Plafker, 1967). Paleomagnetic sample localities: 1-4, Orca Group; 5, Kulthieth Formation at Watson Glacier; 6,8, Poul Creek Formation at Watson Glacier; 7, Kulthieth Formation at Kulthieth Lake type section; 9, Poul Creek Formation at Yakataga Glacier; 10, Poul Creek Formation at Wingham Island....61

43. Equal-area plot of mean magnetic field directions (with 95 percent confidence circles) after AF treatment of pilot specimens from the Yakutat terrane. Arrows indicate changes in directions caused by correcting for tilt of the bedding..................

44. Castle Mountain-Caribou fault system after Detterman and others (1976) and epicenter (star) of the 1984 Sutton earthquake. Heavy lines denote sections with Holocene breaks...............63

45. Generalized tectonostratigraphic terrane map of the Healy quadrangle, after Jones and others (1981, 1983). 1, Anderson Mountain; 2, Caribou Pass; 3 , Clearwater Mountains; 4, Deadman Mountain; 5, Dora Peak; 6, Double Mountain; 7, Lookout Mountain; 8, Mount Pendleton; 9, Nenana Mounta in; 10, Pyramid Peak; 11, West Fork Glacier ; 12, Wyoming

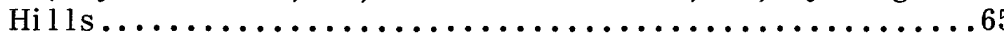




\section{ILLUSTRATIONS--continued}

Figure 46. Simplified bedrock geologic map of the nor theastern

Mount Hayes quadrangle, eastern Alaska Range..........67

47. Location of conodont sample 84APr67 (arrow, black

dot) in the southeastern part of the Valdez quadrangle, distribution of the Strelna Formation ( $\mathrm{s}$ ) and possibly equivalent rocks of the Haley Creek terrane ( $\mathrm{s}$ ?), thicker marble beds in the $\mathrm{s}$ and $\mathrm{s}$ ? units $(\mathrm{m})$, undifferentiated Triassic Nikolai Greenstone and Chitistone Limestone (Trn), undifferentiated Mesozoic flysch and melange of the Chugach terrane (Mzu), and the Border Ranges fault system (BRFS) .............................

48. Scanning-electron photographs of biostratigraphically diagnostic Ear ly Pennsylvanian (early Morrowan) conodonts from USGS collection 29342-PC, Strelna Formation (scale bar $=0.1 \mathrm{~mm}$ ). Most of the conodonts in the collection are juveni le elements. A, B; upper views of left and right $\mathrm{Pa}$ elements of Declinognathodus noduliferus (Ellison and Graves), 70x magnif ication. A, USNM 295835; B, USNM 295836, abraded.

C, D; upper views of two juvenile left Pa elements of the Rhach istognathus muricatus Dunn)-R. primus (Dunn) plexus (D is broken anteriorly and posterior ly); C, USNM 295837, 90X magn if ication; D, USNM $295235,135 \mathrm{X}$ magnif i cat ion.................

49. Distribution of the Tertiary Orca Group (To, Tov) and Tertiary intrusive granitic rocks ( $\mathrm{Tg}$ ) in the Prince William Sound and Katalla areas. Solid dots and numerals indicate fossil localities and sample numbers. (M) =megafossils, (C)=coccoliths, (D) =di a toms and si li cof lagel lates, $(D F)=$ dinoflagellates, $(P)=$ pollen, $(R)=$ radiolarians; all other are foraminifers. Solid triangles are K/Ardated samples from plutons and the numerals are apparent ages in Ma (From Winkler and Plafker, 1981

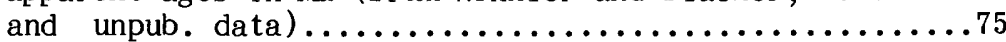

50. Age ranges of fossil collections from the Tertiary Orca Group (numerals in parentheses indicate number of assemblages) and $\mathrm{K}-\mathrm{Ar}$ ages of mineral separates from plutons intrusive into the Orca Group. Dashed bars indicate questionable age assigments. Locations of samples and plutons shown on figure 49. Time scale after Berggren and others (1984)..............76

51. Location and geologic setting of the Border Ranges fault system (BRFS), the suture zone between the Chugach and Wrangellia-Peninsular (composite) terranes along the TACT route. Revised after Metz (1975), Winkler and others (1981), and Wallace (1981). Generalized section (A- $A^{\prime}$ ) showing structural style and relationship between major geologic units in

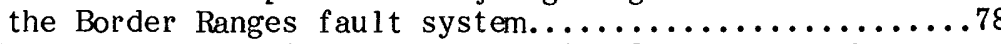

52. Epicenters determined from the U S G S seismograph network in southern Alaska for 201 earthquakes with coda-duration magnitude 3 and larger that occurred 


\section{ILLUSTRATIONS--continued}

in the period October 1983-September 1984. Six heavy symbols indicate events of magnitude $5 \mathrm{mb}$ and larger as determined by NEIS. Non-shaded area indicates approximate extent of network of seismograph stations most frequently used to locate earthquakes; hypocenters located outside of the network tend to be less reliable. Stars

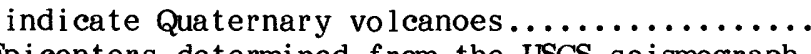

Figure 53. Epicenters determined from the USGS sei smograph network in southern Alaska for 1,598 earthquakes wi th coda-duration magnitude 1 and larger and depths less than $30 \mathrm{~km}$ that occurred in the period October 1983-September 1984. Symbol size varies with magni-

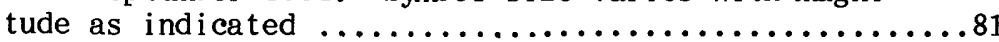

54. Map showing areas in southeastern Alaska discussed in this circular..............................

55. The coincident zone of southeastern Alaska and part of British Columbia, Canada. (A), Juxtaposi$t i o n$ of $f i v e$ of the eight major geologic features in the coincident zone. (B) The -50 malal gravity contour, crest of the persistent aeromagnetic high, and Coast Range megalineament, in the southeastern

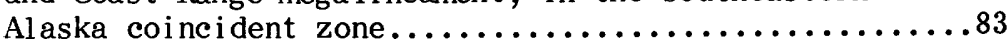

56. Location of the fossiliferous section near the Meade Glacier, of the ultramafic mass to the west, and the major geologic features. Base map from USGS $1: 250,000$ series At lin quadrangle..............

57. Diagrammatic stratigraphic column for fossiliferous section, upper Meade Glacier area, At lin A-8 quadrangle. Thi cknesses est imated; thicknesses of thinner units exaggerated........... 87

58. Distribution of metamorphic effects in the eastern Petersburg quadrangle...................90 


\section{TABLES}

Table 1. Percent (by weight) of each stream sediment sample that was dissolved in dilute $\mathrm{HCl}$ during preparation of insoluble residues.............................

2. Selected anomalous rock samples from the central and northwestern Baird Mountains quadrangle. Results are of semiquantitative emission spectrography, except for An and selected elements (marked by asterisk), which were analyzed by atomic absorption............9

3. Selected anomalous stream-sediment samples from the central and northwestern Baird Mountains quadrangle. Results are of semiquantitative emission spectro-

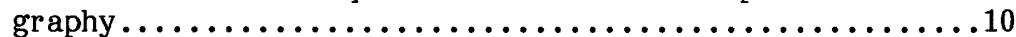

4. Previously reported geochemi cal anomalies.............10

5. Sumary of sedimentologic characteristics of channelized lower parts of thinning- and fining-upward

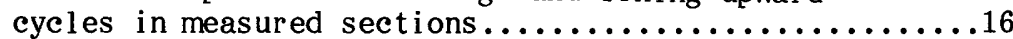

6. Results of analyses of gold-quartz veins from the

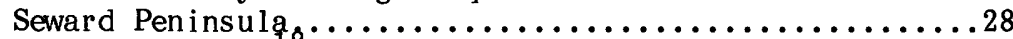

7. Oxygen-isotope $\left(\delta^{18} \mathrm{O}\right)$ values for quartz from boudins and gold-bearing veins, Seward Peninsula; values are reported in permil relative to Standard Mean

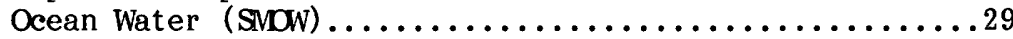

8. Southwestern Alaska terrane/subterrane linkages showing the ir characteristics and constraints....................

9. Characteristics of the dismembered Newenham ophiolite

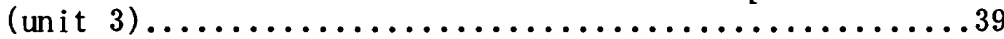

10. Characteristics of schistose nappe units of Cape Peirce

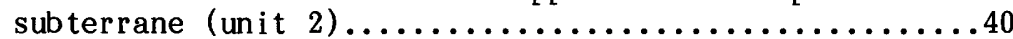

11. Uranium-lead isotopic data for metaigneous rocks in the Macomb, Jarvis Creek Glacier, and Hayes Glacier terranes, nor theastern Mount Hayes quadrangle, eastern

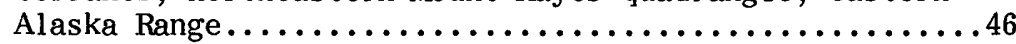

12. Difference in time of arrival of low and high tides at selected sites in Turnaga in Arm from the published low and high tide times at the Anchorage tidal station.....49

13. Maximum and minimum values of suspended sediment and specific conductance measurements from sites in Turnagain Arm at various times during a tidal cycle, May-Sep tember, 1981-1982. * $*$ samples taken during

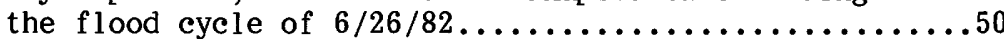

14. Parameters for interpreted bodies shown in figure 37 . $\mathrm{Y} 1$ and $\mathrm{Y} 2$ are distances the bodies are assumed to extend in front of and behind the plane of the figure, respectively. Listed density values represent differences from densities of a reference section supposed here to hagve $2.67 \mathrm{~g} / \mathrm{cm}^{3}$ density to $8.8 \mathrm{~km}$ depth, and $2.90 \mathrm{~g} / \mathrm{cm}^{3}$ density from $8.8 \mathrm{~km}$ to $34 \mathrm{~km}$ depth.........54

15. Var imax rotation factor loadings for stream-sediment (S) and heavy-mineral concentrate (C) data. Loadings less than 0.40 have been omitted. aa, atomic absorption analysis; all other analyses by semiquantitative emission spectrography..........................64

16. Stratigraphy and petrology of Devonian igneous-arc terranes, northeastern Mount Hayes quadrangle, eastern Al aska Range.................................68 



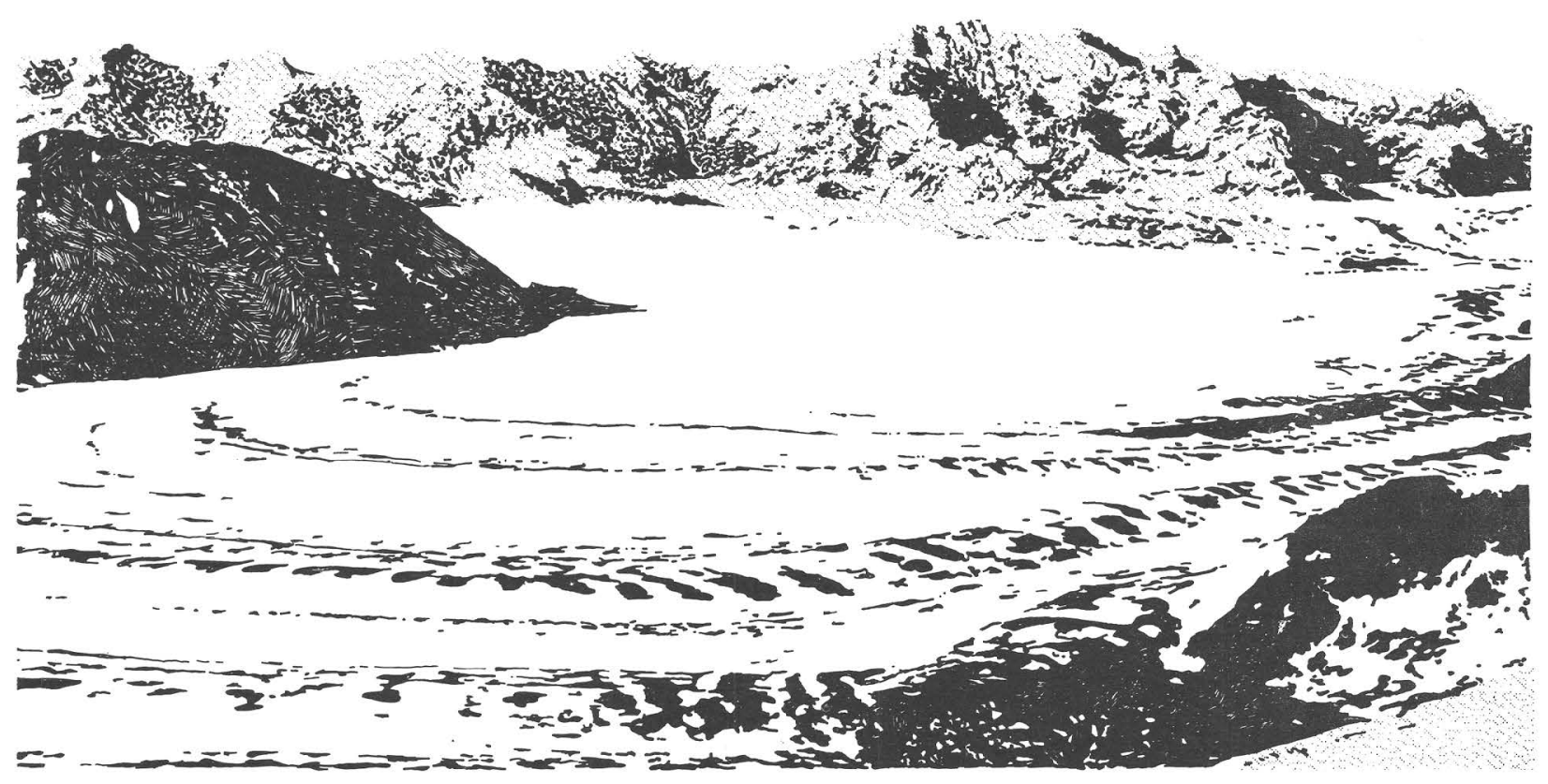

\section{THE UNITED STATES GEOLOGICAL SURVEY IN ALASKA: ACCOMPLISHMENTS DURING 1984}

\section{Susan Bartsch-Winkler, Editor}

\begin{abstract}
This circular contains short reports about many of the geologic studies carried out in Alaska by the U.S. Geological Survey and cooperating agencies during 1984. The topics cover a wide range in scientific and economic interest.

\section{INTRODUCTION}

The U.S. Geological Survey investigates various geological aspects of the onshore and offshore areas of Alaska. These studies range in scope from topical investigations to statewide and reconnaissance regional assessments and include a variety of topics. This circular contains short reports derived from some of these studies carried out by the U.S. Geological Survey and cooperating agencies or organizations during 1984. An author index of included reports and a topical crossreference are appended at the back of the volume. These will assist the reader in locating work by specific authors or about a particular topic. A complete listing of published reports about Alaska produced in 1984 can be found in Publications of the U.S. Geological Survey, 1984.
\end{abstract}

Single copies of this listing are distributed free by application to the Branch of Distribution, U.S. Geological Survey, 604 South Pickett Street, Alexandria, VA 22034.

The reports are presented in the order of their occurrence from north to south in each of the six regional subdivisions of Alaska shown in figure 1. Index maps showing the individual study areas are included near the beginning of each section.

\section{NORTHERN ALASKA}

(Figure 2 shows study areas described.)

\section{GRAVITY LOWS MAY INDICATE PLEISTOCENE DEPOSITS \\ BENEATH GLACIAL LAKE NOATAK}

\section{David F. Barnes}

For nearly 20 years, gravity maps (for example, Barnes, 1967, 1977) have shown a distinct gravity low near the west-central Brooks Range. The gravity feature occupies much of the physiographic depression identified as the Aniuk Lowland (Wahrhaftig, 1965), and its minimum Bouguer anomaly was measured along the Noatak River about 


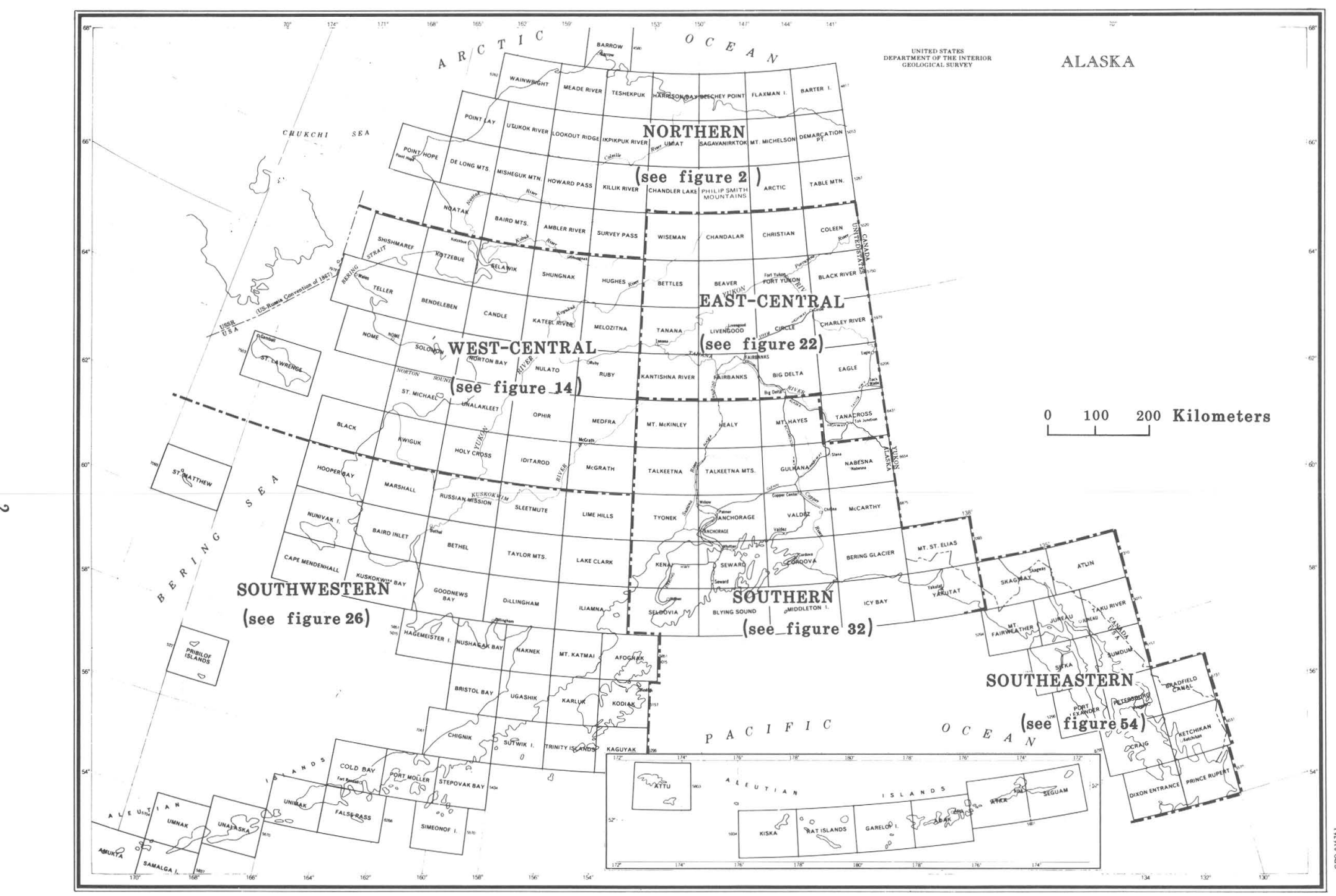

Figure 1.--Regions of Alaska used in this circular. Referenced figures indicate regional index maps that show areas discussed. 


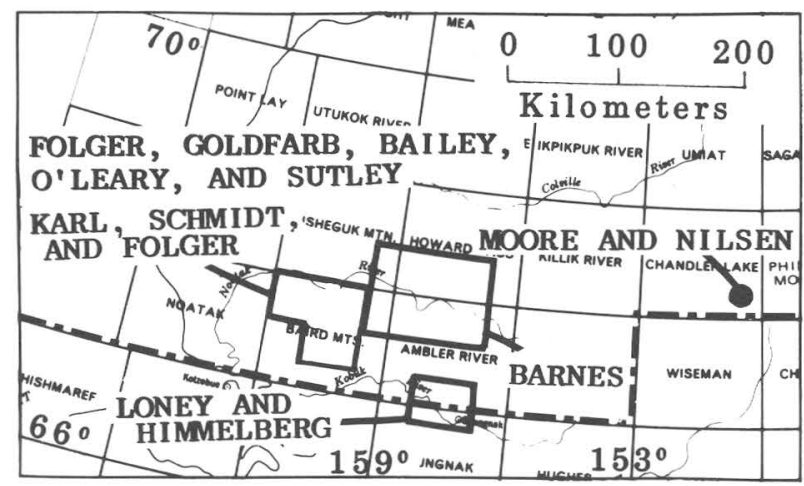

Figure 2.--Map showing areas in northern Alaska discussed in this circular.

$15 \mathrm{~km}$ upstream (east) of its junction with the Aniuk River. Bedrock outcrops within or near the lowlands consist primarily of Paleozoic sedimentary and volcanic rocks (Mayfield and Tailleur, 1978; I. L. Tailleur, USGS, oral commun., March 8, 1985). Neither geologic nor aeromagnetic maps (Hackett, 1980) suggest that low-density plutons, vesicular volcanic rocks, or other bedrock features can explain the 40-mGal gravity low. Correlations between this and similar physiographic and gravitational features in Alaska (Barnes, 1961, 1976) and the Colorado Rockies (Behrendt and others, 1969) suggest the cause of the gravity low to be a structural depression, in which lower portions are composed of Tertiary sedimentary rocks. A similar explanation was given to such a gravitational feature at the Mission Lowland near the mouth of the Noatak River (Barnes and Tailleur, 1970) and later was partly supported by discovery of a small nearby Tertiary outcrop (Ellersieck and others, 1979).

Surficial geologic maps at the Aniuk anomaly (Hamilton, 1984 a,b; Hamilton and Ashley, 1983; Hamilton and Van Etten, 1984) reveal evidence for a large lake dammed repeatedly by glacier ice issuing from the DeLong Mountains during middle and late Pleistocene time. Close correlation between the gravity anomaly and glacial features suggests that the entire anomaly could result from sculpture and later sediment filling of the Aniuk Lowland by Pleistocene processes. Figure 3 compares the geographic distribution of the existing gravity data with a simplified version of a map by Hamilton and Van Etten (1984) showing the lake and contemporaneous glaciers during the Itkillik glaciation of inferred early Wisconsin age (Hamilton and Hopkins, 1982) when it reached its greatest areal extent $\left(>4,000 \mathrm{~km}^{2}\right)$. The gravity contouring is interpretive and locally may not justify refined modelling or thickness calculations.

Recent surficial maps and descriptions define the shape and history of Lake Noatak and its glacial dams (Hamilton, 1984 a,b; Hamilton and Van Etten, 1984). Lake and glacier outlines used in figure 3 are modified from the published map (T. D. Hamilton, USGS, written commun., March 7, 1985). The glacier system that flowed southeastward from the DeLong Mountains (fig. 2) dammed the lower valley creating Lake Noatak. The size, depth, and outlet locations of the lake varied with glacier position, size of the glacial dam, and amount of isostatic flexure of the basin. The primary outlet at stages of reduced glacier size was westward along the margin of the damming valley glacier and down the valley of Aklamayak Creek (fig. 3); at higher stages, the lake drained north through Howard Pass or southward into the Hunt and Kobuk Rivers. Another valley glacier flowed into the eastern margin of the lake, away from the high peaks of the western Brooks Range.

Four relations between gravity contours and lake configuration at the Itkillik stage should be noted: (1) A slight correlation exists between closure of the $-80 \mathrm{mGal}$ contour and the shape of the lake and location of the glaciers flowing into it, suggesting that part of this gravity low could represent low-density sediment covering the lake bottom. Infinite-slab calculations using a sediment density of $2.00 \mathrm{gm} / \mathrm{cm}^{3}$ suggest that a $10-\mathrm{mGal}$ anomaly might represent about 350 mof sediment. This result would imply a lake bottom close to present sea level and much buried bedrock topography. Of course, the sediments could be less dense and the lake bottom somewhat higher. (2) The location of the western $-90 \mathrm{mGal}$ closure near the foot of the primary damming DeLong Mountain ice lobe could represent a deep excavation near the glacier terminus. (3) The elongate SW - NE gravity low extending from the southern Hunt River outlet of the lake to the older Howard Pass outlet could represent a former flow direction and lake bottom channel, but the $20-\mathrm{mGal}$ amplitude is very large and would represent a channel filled by an additional $400 \mathrm{~m}$ of low-density (about $1.5 \mathrm{gm} / \mathrm{cm}^{3}$ ) sediment. (4) The $-120 \mathrm{mGal}$ low to the east suggests an even thicker section of sediment at the terminus of the valley glacier that flowed into the lake's eastern margin.

Before further discussion, it is worth summarizing the total thickness of material that this $\mathbf{5 0}$ mGal anomaly could represent for materials of different density by infinite-slab approximation. If the sediment has a density of $2.00 \mathrm{~g} / \mathrm{cm}^{3}$, typical of most valley fill, the $50 \mathrm{mGal}$ anomaly would represent a sediment thickness of about $1,900 \mathrm{~m}$; if the density is $1.4 \mathrm{~g} / \mathrm{cm}^{3}$, as determined for some of the ice-wedge-filled Gubik Formation on the North Slope (Woolson, 1962), the thickness could be only $900 \mathrm{~m}$; if the fill were pure ice with a veneer of sediments, the thickness could be less than $700 \mathrm{~m}$. All suppositions suggest basin depths below present sea level. The presence of large proportions of ice seems unlikely, unless there was rapid drainage of the lake and ensuing sediments were deposited over a large ice body. In such an event, normal geother- 


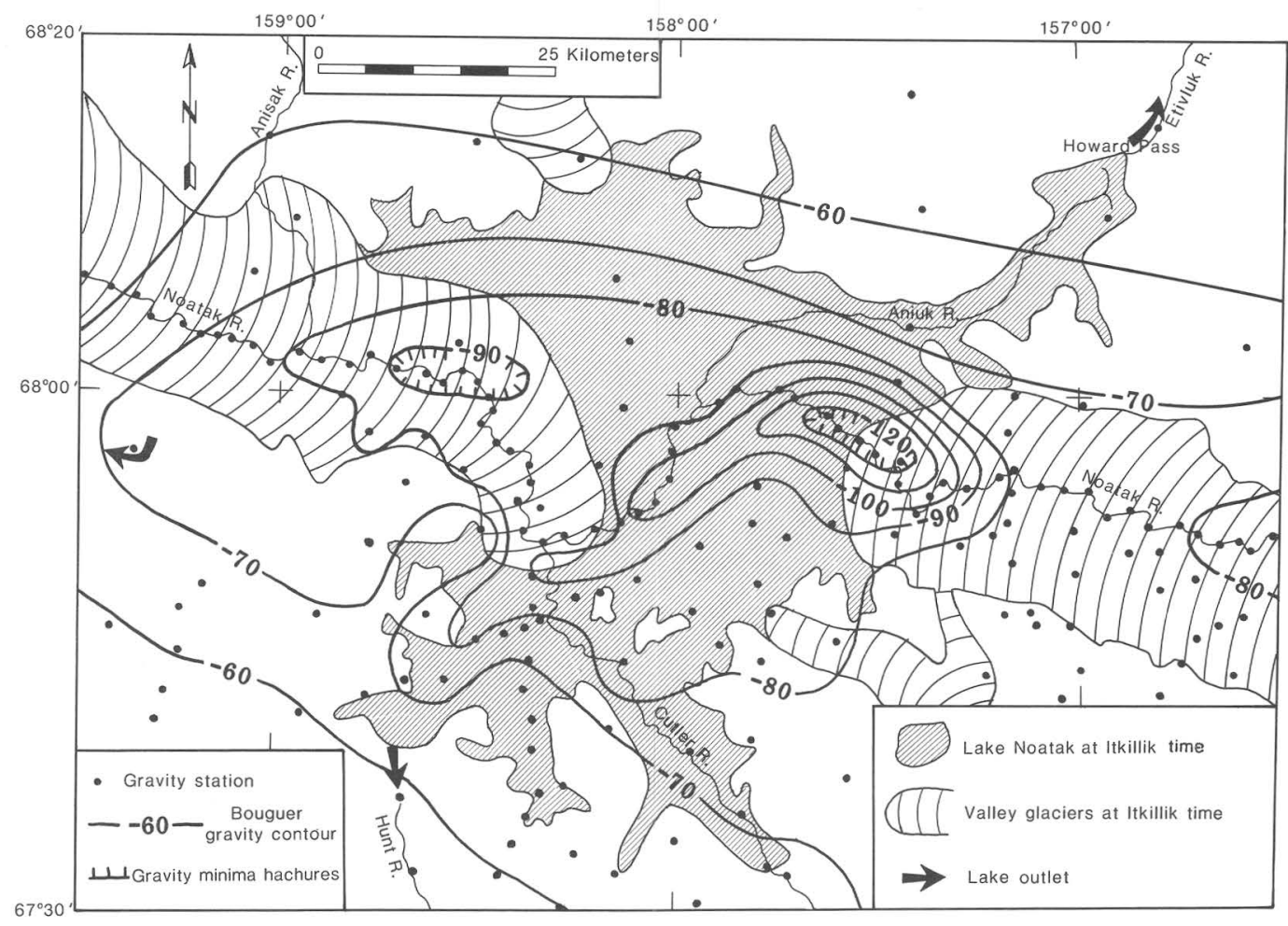

Figure 3.--Relation between Bouguer gravity data contours, the major present river drainage system, the Pleistocene (Itkillik glaciation) extent of Lake Noatak, former lake outlet channels, and major Itkillik valley glaciers. Complete Bouguer anomalies are based on a standard density of $2.67 \mathrm{~g} / \mathrm{cm}^{3}$, the IGSN-74 datum, and the 1967 Geodetic Reference System (Barnes, 1977), and the terrain corrections were derived from a digital elevation model (DEM) (Barnes, 1984). Contour interval is $10 \mathrm{mGal}$.

mal heat flow would have melted at least a few hundred meters of ice since formation of the body in early Wisconsin time.

Regardless of the type of basin fill, the estimated thicknesses do not exceed reported depths of some fiords and glacially excavated lakes (Flint, 1971; Hutchinson, 1957). Perhaps the world's deepest fiord, Skelton Inlet, Antaretica, has a depth of $1,933 \mathrm{~m}$ near the junction of a valley glacier (of comparable width to Lake Noatak glacier) and the floating Ross Ice Shelf (Crary, 1966). It is likely that excavation is highly efficient at the location where the grounded glacier thins to a floating ice sheet (Crary, 1966). Such features are probably rare in mountain-lake settings, but lacustrine floating glacier tongues have been reported at perennially frozen lakes in the Angiussaq Mountains of northern Greenland (Barnes, 1960) and in Antaretica (Lyon, 1979).

Several factors make present-day Lake Angiussaq and Pleistocene Lake Noatak comparable. Both had large glacier dams at their deepest margins, enabling water temperature to remain near freezing throughout lake depth. Both had outlets in shallower, restricted arms, where open water could form during the Arctic summer without disturbing the larger expanse of perennial ice cover. The mountain setting and surface elevations of the two lakes are comparable. Furthermore, several factors suggest that Pleistocene air temperatures may have been $4-6{ }^{\circ} \mathrm{C}$ cooler than present air temperatures (Flint, 1971), making the mean annual temperature of Pleistocene Arctic Alaska similar to that of present-day northern Greenland.

Hamilton's surficial mapping (1984 a, b) clearly records evidence of annual open water and terminal moraines of grounded valley glaciers, but the thick cover of lacustrine sediment could conceal evidence for earlier ice conditions capable of deep excavation. A Tertiary structural depression or felsic intrusion may still provide the most logical explanation for this Noatak Valley gravity minimum. However, the possible Pleistocene fiord-like excavation and later sedimentation (perhaps with abundant ice) of an ancient perennially frozen lake basin deserves this brief documentation. 


\section{REFERENCES CITED}

Barnes, D. F., 1960, An investigation of a perennially frozen lake: Air Force Surveys in Geophysies no. 129, Air Force Cambridge Research Laboratories, 134 p.

Barnes, D. F., 1961, Gravity low at Minto Flats, Alaska; in Geological Survey research 1961: U.S. Geological Survey Professional Paper 424-D, p. 254-257.

Barnes, D. F., 1967, Four preliminary gravity maps of Alaska: U.S. Geological Survey Open-File Report, 4 sheets.

Barnes, D. F., 1976, Gravitational evidence for more Alaskan sedimentary basins (abs.): American Association of Petroleum Geologists Bulletin, v. 60, n. 12, p. 2174-2175.

Barnes, D. F., 1977, Bouguer gravity map of Alaska: U.S. Geological Survey Geophysical Investigations Map GP-913, 1 sheet, scale $1: 2,500,000$.

Barnes, D. F., 1984, Digital elevation models improve processing of Alaskan gravity data, in Coonrad, W. L., and Elliott, R. L., eds., U.S. Geological Survey in Alaska-Accomplishments during 1981: U.S. Geological Survey Circular 868 p. 5-7.

Barnes, D. F., and Tailleur, I. L., 1970, Preliminary interpretation of geophysical data from the lower Noatak River Basin, Alaska: U.S. Geological Survey Open-File Report, 15 p., 3 maps.

Behrendt, J. C., Popenoe, Peter, and Mattick, R. E., 1969, A geophysical study of North Park and the surrounding ranges, Colorado: Geological Society of American Bulletin, v. 80, n. 8, p. 1523-1538.

Crary, A. P., 1966, Mechanism for fiord formation indicated by studies of an ice covered inlet: Geological Society of America Bulletin, v. 77, no. 9, p. 911-930.

Ellersieck, Inyo, Tailleur, I. L., Mayfield, C. F., and Curtis, S. M., 1979, A new find of Upper Cretaceous or Tertiary sedimentary rocks in the Noatak Valley, in Johnson, K.M., and Williams, J. R., eds., U.S. Geological Survey in Alaska-Accomplishments during 1978: U.S. Geological Survey Circular 804B, p. B13.

Flint, R. F., 1971, Glacial and Quaternary Geology: New York, John Wiley, 892 p.

Hackett, S. W., 1980, Aeromagnetic interpretation maps of the Ambler River quadrangle, Alaska: U.S. Geological Survey Open-File Report 78-120K, 19 p., 3 maps, scale $1: 250,000$.

Hamilton, T. D., 1984a, Surficial geologic map, Howard Pass quadrangle, Alaska: U.S. Geological Survey Miscellaneous Field Studies Map MF 1677, 1 sheet, scale 1:250,000.

Hamilton, T. D., 1984b, Surficial geologic map, Ambler River quadrangle, Alaska: U.S. Geo- logical Survey Miscellaneous Field studies Map MF 1678, 1 sheet, scale 1:250,( $) 0$.

Hamilton, T. D. and Ashley, G. M., 1983, Glacial Lake Noatak, northwestern Alaska-Paleogeography, history and environmental implications (abs.): Geological Scciety of America Abstracts with Programs, v. 15, p. 590 .

Hamilton, T. D. and Hopkins, D. M., 1982, Correlation of northern Alaskan glacial deposits - A provisional stratigraphic framerork, in Coonrad, W. L., ed., The United States Geological Survey in Alaska-Accomplishments during 1980: U.S. Geological Survey Circular 844 , p. $15-18$.

Hamilton, T. D. and Van Etten, D. P., 1984, Late Pleistocene glacial dams in the Noatak Valley, in Coonrad, W. L. and Elliott, R. L., eds.: The United States Geological Survey in Alaska-Accomplishments during 1981: U.S. Geological Survey Circular 868, p. 21-23.

Hutchinson, G. E., 1957, A Treatise on Limnology, New York, John Wiley, 1015 p.

Lyon, G. L., 1979, Some aspects of ice topography of Trough Lake, southern Victoria Land, Antarctica: New Zealand Journal of Geology and Geophysics, v. 22, n.2., p. 281-284.

Mayfield, C. F. and Tailleur, I. L., 1978, Bedrock geologic map of the Ambler River quadrangle, Alaska: U.S. Geologicnl Survey Open-File Report 78-120A, scale 1:250,000.

Wahrhaftig, Clyde, 1965, Physiographic divisions of Alaska: U.S. Geological Survey Professional Paper 482, 52 p., 6 plates.

Woolson, J. R., 1962, Seismic and gravity surveys of Naval Petroleum Reserve no. 4, and adjoining areas, Alaska: U.S. Geological Survey Professional Paper 304-A, 25 p., 19 plates.

Reviewers: Andrew Griscom and T. D. Hamilton

USE OF STREAM-SEDIMENT INSOLUBLE RESIDUES IN GEOCHEMICAL EXPLORATION FOR CARBONATE-HOSTED MINERAL DEPOSITS IN THE BAIRD MOUNTAINS

\author{
Peter F. Folger, Richard J. Goldfarb, \\ Elizabeth A. Bailey, Richard M. O'Leqry \\ and Stephen J. Sutley
}

The purpose of this study is to determine whether insoluble residues of stream-sediment samples can be used as an effective means of detecting carbonate-hosted mineral deposits. Viets $\varepsilon$ nd others (1983) outlined mineralized trends in southeast Missouri using insoluble residues of drill core samples. By dissolving all the carbonate material in weak acid, values for many elements were significantly enhanced, showing that mineralization ex- 


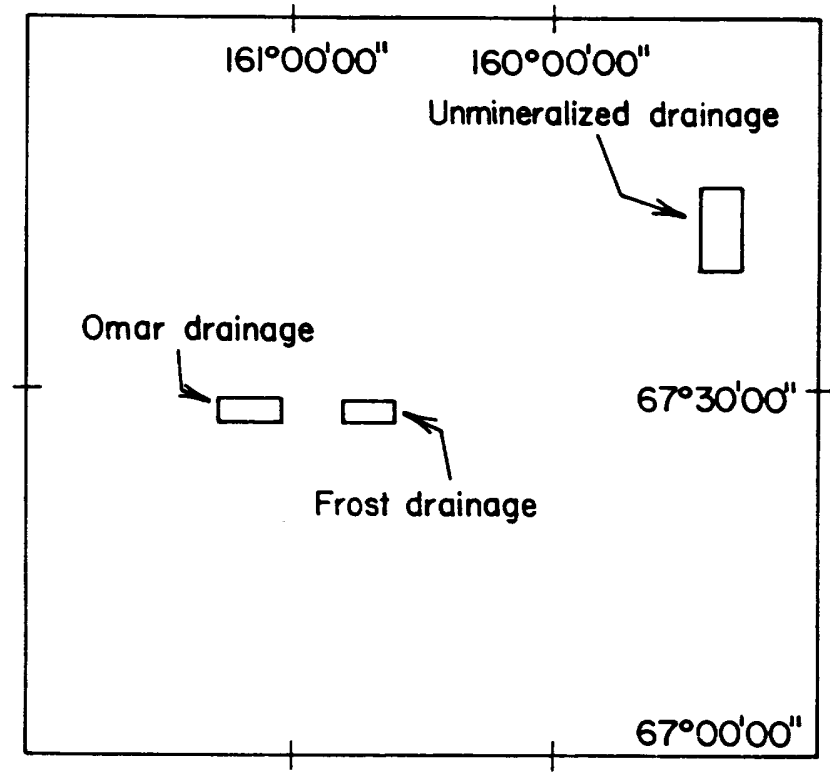

Figure 4.--Schematic index map showing approximate locations of the three drainage areas within the Baird Mountains quadrangle. Drainage area dimensions are not to scale.

tended into rocks previously thought barren (Erickson and others, 1978, 1979). We used a similar leaching process with stream-sediment samples collected from creeks draining the Omar copper deposit, the Frost lead-zinc-barite occurrence, and an unmineralized area within the Baird Mountains quadrangle (fig. 4).

The catchment areas for these drainages are underlain by Paleozoic limestones and dolostones, though the lithologies at the Frost occurrence and the unmineralized area also contain significant amounts of phyllitic rocks. Mineralization at the Omar deposit consists of chalcopyrite and bornite, lesser tennantite-tetrahedrite, pyrite, and minor chalcocite. Anomalous zinc, lead, and cobalt values accompany the copper mineralization at Omar. Mineralization at the Frost occurrence is less well known, but includes sphalerite, galena, barite, and pyrite. Secondary copper carbonates and iron oxides occur at Omar, and iron oxides predominate at the Frost occurrence.

Stream-sediment samples and heavy-mineral concentrates were collected from the three drainage systems (fig. 5). Splits of the very-fine-sand

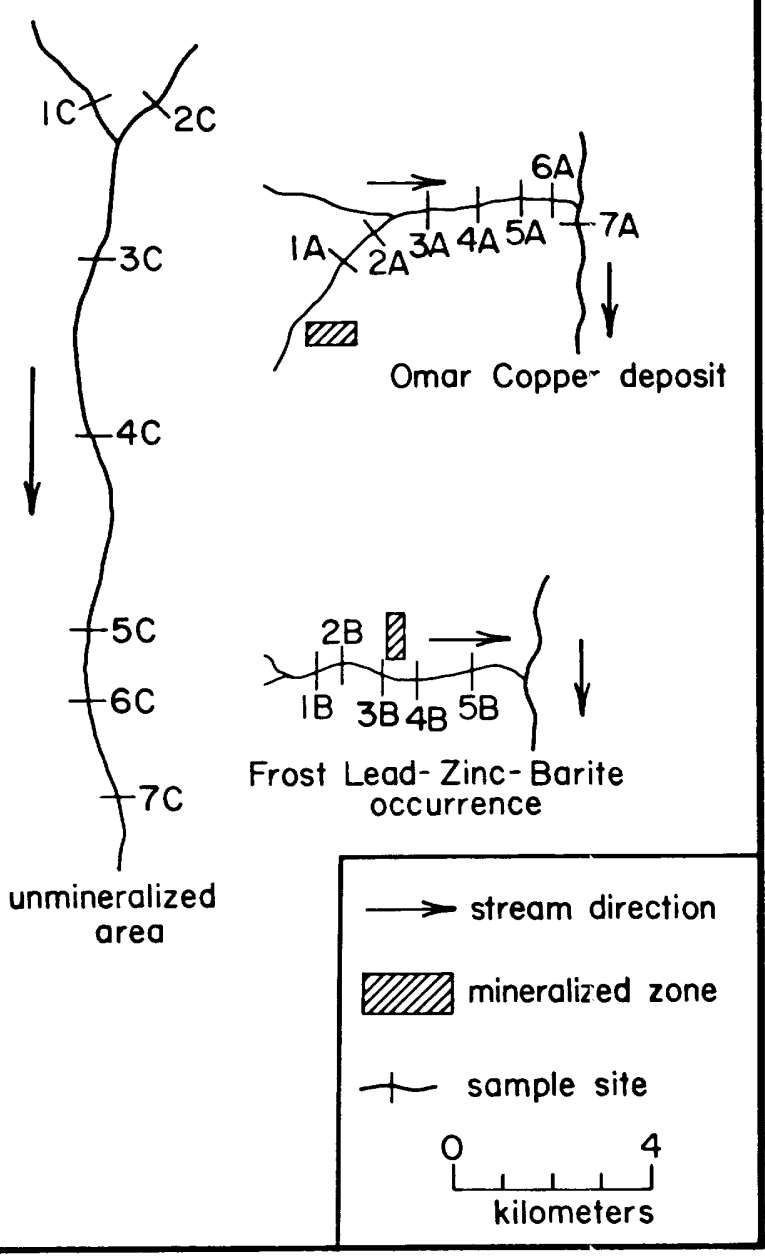

Figure 5.--Schematic diagram of drainages and sample sites for the three study areas shown in figure 4.

size fraction (62.5-125 microns) of the stream-sediment samples were treated with a cold 5:1 mixture of deionized $\mathrm{H}_{2} \mathrm{O}$ and concentrated $\mathrm{HCl}$ until all visible reactions ceased. Insoluble residues and untreated splits were analyzed for 31 elements by semiquantitative emission spectrography and for As, $\mathrm{Zn}, \mathrm{Cd}, \mathrm{Bi}$, and $\mathrm{Sb}$ by atomic absorption analysis. The nonmagnetic fraction of the heavy-mineral concentrates was analyzed by emission spectrography.

Table 1.--Percent (by weight) of each stream sediment sample that was dissolved in dilute $\mathrm{HCl}$ during preparation of insoluble residues

\begin{tabular}{|c|c|c|c|c|c|c|c|c|c|c|c|c|c|c|c|c|c|c|c|}
\hline & \multicolumn{7}{|c|}{ OMAR DEPOSIT } & \multicolumn{5}{|c|}{ FROST OCCURRENCE } & \multicolumn{7}{|c|}{ UNMINERALIZED AREA } \\
\hline $\mathrm{am}$ & $1 \mathrm{~A}$ & $2 \mathrm{~A}$ & $3 \mathrm{~A}$ & $4 \mathrm{~A}$ & $5 \mathrm{~A}$ & $6 \mathrm{~A}$ & $7 \mathrm{~A}$ & $1 \mathrm{~B}$ & $2 B$ & $3 \mathrm{~B}$ & $4 \mathrm{~B}$ & $5 \mathrm{~B}$ & $1 \mathrm{C}$ & $2 \mathrm{C}$ & $3 \mathrm{C}$ & $4 \mathrm{C}$ & $5 \mathrm{C}$ & $6 \mathrm{C}$ & $7 \mathrm{C}$ \\
\hline $\begin{array}{l}\text { Percent } \\
\text { Dissolved }\end{array}$ & 78 & 92 & 80 & 77 & 76 & 77 & - & 20 & 45 & 35 & 38 & 38 & 19 & 4 & 12 & 33 & 14 & $5 ?$ & 57 \\
\hline
\end{tabular}




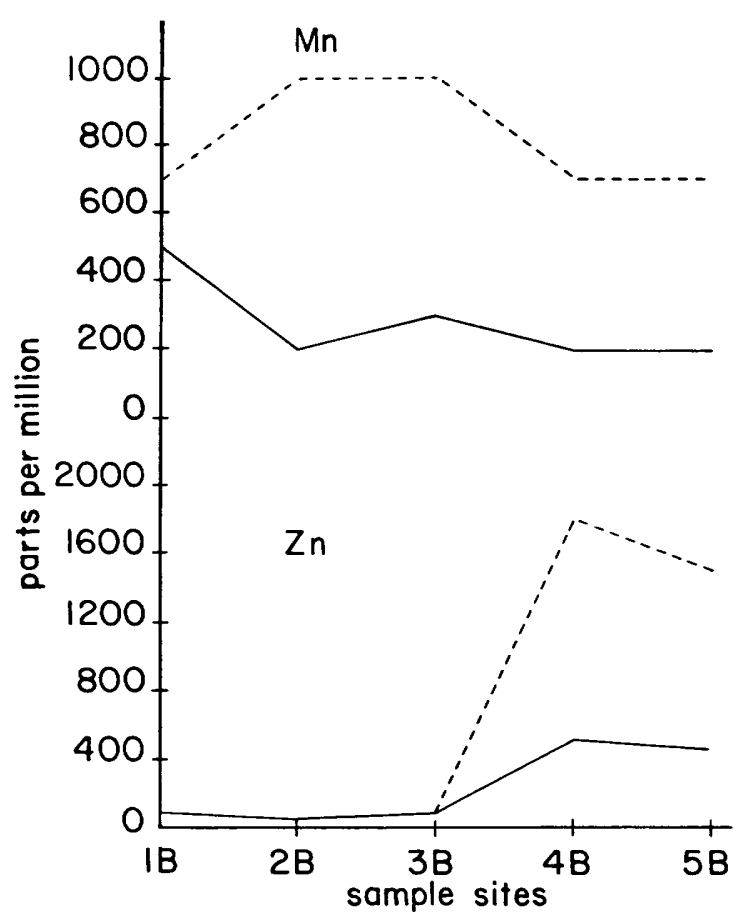

Figure 6.--Comparison of results of analyses of very fine sand samples that have been leached (insoluble residue samples-solid line) with untreated samples (dashed line) from the Omar drainage. Cu was analyzed spectrographically; As was analyzed by the atomic absorption method.

Insoluble residues from the Omar drainage show consistently higher values for $\mathrm{Cu}$ and $\mathrm{As}$ when compared to untreated samples (fig. 6). Co, Fe, and $\mathrm{Zn}$ are also enhanced, though less significantly, in the leached samples. Values for all five elements show no consistent difference between treated and untreated samples from the unmineralized area, suggesting that the leaching process does not enhance background concentrations.

It is important to note that untreated samples at Omar are anomalous in $\mathrm{Cu}$ and As proximal to the source but that values become progressively indistinguishable from background $3-4 \mathrm{~km}$ downstream. In insoluble residues, these elements occur at anomalous levels as far as 5-6 km downstream from the source. The leaching process increased the contrast between background values for the elements and the values associated with mineralization at Omar. We suggest that insoluble residues of carbonate-dominated stream sediments could help distinguish mineralization similar to that at Omar more readily than untreated stream sediments. Furthermore, a reconnaissance stream-sediment survey using the residues would detect this type of mineralization further downstream than would the untreated stream-sediment samples.

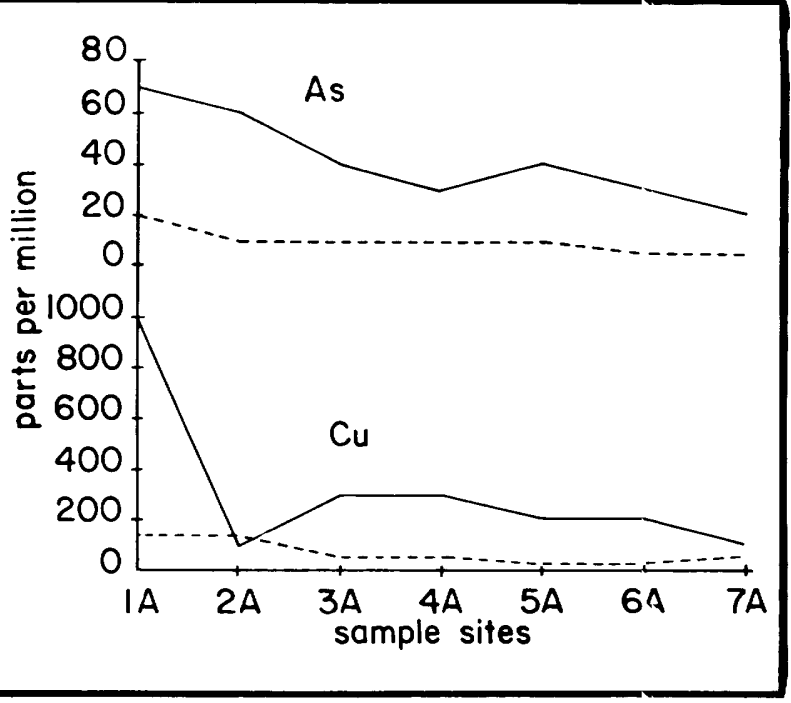

Figure 7.--Comparison of results of analyse : of very fine sand samples that have been leached (s?lid line) with untreated samples (dashed line) from the Frost drainage. Mn was analyzed spectrographically; Zn was analyzed by the atomic absorption metl ad.

Microscopic examination of heavy-mineral concentrate samples from the Omar deposit indicates that chalcopyrite, bornite, pyrite, and possibly other sulfides have moved mechanically downstream from the source. Concentrate analyses als? show a significant enhancement of values for $\mathrm{Cu}$ and $\mathrm{As}$ closest to the mineralization. However, the nonmagnetic fractions of samples $4 \mathrm{~A}-6 \mathrm{~A}$ were too small for analysis. Heavy-mineral concentrnte samples from carbonate-dominated stream sadiments (table 1) could potentially be insufficient ir size for analysis when heavy minerals representative of mineralization diminish rapidly downstream. In this case, both untreated stream-sediment samples and heavy-mineral concentrate samples would not be as effective a sample medium as insoluble residues. During preparation of insoluble residues, the diluting effects of carbonate material woulc be removed, and the remaining minerals prese"ved for analysis.

Results from samples at the Frost oc?urrence suggest that $\mathrm{Pb}, \mathrm{Zn}$, and $\mathrm{Cd}$ travel both in detrital sulfide minerals and as a water-soluble phase. Metal values from insoluble residue samples are lower than those from corresponding untreated samples downstream from mineralization. Microscopic examination of heavy-mineral concentrates reveals that while galena and sphalerite are prosent as detrital minerals, Fe-oxides, and possi-ly $\mathrm{Mn}$ oxides, are present as grain coatings and might have scavenged elements released during chemical weathering (Chao and Theobald, 1976). These coatings would be released with the carbonate material during acid treatment, resulting in diminished values 
for many metallic elements (fig. 7). Also, Viets and others (1983) mention that very-fine grained galena is partially soluble in dilute acid. Possibly 6-12 percent of the overall $\mathrm{Pb}$ content from the Frost samples might have been lost during preparation of the insoluble residues.

The presence of both primary and secondary mineral phases, various rock types, and the combination of physical and chemical weathering in the stream environment, complicates the use of insoluble residues as an exploration tool. However, in areas underlain predominantly by carbonate rocks and where collection of heavy-mineral concentrate samples might not prove effective, analysis of insoluble residues of stream-sediment samples could be a valuable technique for detecting mineralization.

\section{REFERENCES CITED}

Chao, T. T., and Theobald, P. K., 1976, The significance of secondary iron and manganese oxides in geochemical exploration: Economic Geology, v. 71, p. 1560-1569.

Erickson, R. L., Mosier, E. L., and Viets, J. G., 1978, Generalized geologic and summary maps of Rolla 1 × 2 degree quadrangle, Missouri: U.S. Geological Survey Miscellaneous Field Studies Map MF-1004-A, scale 1:250,000.

Erickson, R. L., Mosier, E. L., Viets, J. G., and King, S. C., 1979, Generalized geologic and geochemical maps of the Cambrian Bonneterre Formation, Rolla 1 x 2 degree quadrangle, Missouri: U.S. Geological Survey Miscellaneous Field Studies Map MF-1004-B, scale $1: 250,000$.

Viets, J. G., Mosier, E. L., and Erickson, M. S., 1983, Geochemical variations of major, minor, and trace elements in samples of the

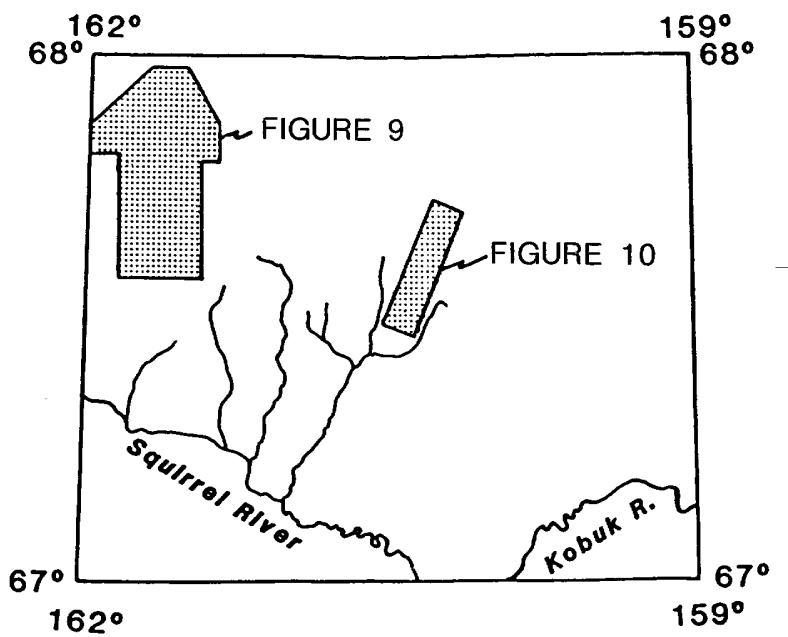

Figure 8.--Area of anomalous samples in the central and northwestern portions of the Baird Mountains quadrangle, and locations of figures 9 it and 10.
Bonneterre Formation from drill holes transecting the Viburnum Trend $\mathrm{Pb}-\mathrm{Zn}$ district of southeast Missouri: in Kisvarsanyi and others, eds., International Conference on Mississippi Valley Type Lead-Zinc Deposits, Rolla, University of Missouri, p. 174-186.

Reviewers: M. S. Erickson and H. D. King:

\section{SELECTED ANOMALOUS ROCK AND SEDIMENT SAMPLES FROM CENTRAL AND NORTHWESTERN BAIRD MOUNTAINS QUADRANGLE}

\author{
Susan M. Karl, Jeanine M. Schmidt, \\ and Peter F. Folger
}

(with contributions by

Bill Thompson, Randy Baker, Inyo Ellersieck, Richard O'Leary, Steven Sutley, Elizabeth Bailey, and David Siems)

The Baird Mountains quadrangle ras been an area of recognized mineral potential since the early 1900's (Smith, 1911; 1913). Significant base- and precious-metal deposits (Red Dog, Arctic, and others) occur in adjacent quadrangles in rock units along regional strike with, or lithologically similar to, unnamed rock units in the Baird Mountains quadrangle (Degenhart and others, 1978; Plahuta, 1978). Systematic stream-sediment and rock geochemical studies are being conducted as part of the Alaska Mineral Resource Assessment Program (AMRAP) in the Baird Mountains quadrangle. Known mineral occurrences are being reevaluated on the basis of on new reconnaissance geologic mapping, local detailed mapping, and statistical analyses of regional geochemical data.

Presented here are 23 rock samples (table 2) and 23 stream-sediment samples (table 3 ) with high metal values collected in 1983-84. All samples are from localities (figs. 8-10) not previously reported, except those from a tributary of Kivivik Creek in the Kilyaktalik Peaks area (Ellersieck and others, 1984). It is of interest that the 46 samples cluster in the areas of figures 9 and 10 , and have metal values greater than twice background val'es. Background values for the rocks were determined based on work done in a nearby quadrangle (Grybeck and others, 1982), and on univariate statistics performed on rock samples collected in 1983-84. Background values for stream-sediment samples wer? determined from univariate statistics performed on streamsediment samples collected in the Baird Mountains quadrangle between 1976 and 1981 (Inyc Ellersieck, USGS, unpublished data), and on stream-sediment samples collected in 1983-84. Values for rock and stream-sediment samples that are greater than twice background fall above the 95th pe ${ }^{\text {r centile for }}$ the elements of interest here, and are considered anomalously high for the area. 
Table 2.--Selected anomalous rock samples from the central and northwestern Baird Mountains Quadrangle. Results are of semiquantitative emission spectrography, except for $\mathrm{Zn}$ and selected elements (marked by asterisk), which were analyzed by atomic absorbtion. All elements reported in parts per million. G, Greater than the value shown; L, Detected, but below the level of determination;

$\mathrm{N}$, Not detected at limit of detection (limits given in parentheses at column heading)

\begin{tabular}{|c|c|c|c|c|c|c|c|c|c|c|c|c|c|}
\hline $\begin{array}{c}\text { Loca- } \\
\text { tion }\end{array}$ & Sample & Latitude & Longitude & Rock Type & $\begin{array}{c}\mathrm{Ag} \\
(0.5)\end{array}$ & $\begin{array}{r}\mathrm{Ba} \\
(10)\end{array}$ & $\begin{array}{r}\mathrm{Cr} \\
(10)\end{array}$ & $\begin{array}{l}\mathrm{Cu} \\
(5)\end{array}$ & $\begin{array}{l}\text { Mo } \\
\text { (5) }\end{array}$ & $\begin{array}{l}\mathrm{Ni} \\
(5)\end{array}$ & $\begin{array}{c}\mathrm{Pb} \\
(10)\end{array}$ & $\begin{array}{c}\mathrm{Zn} \\
(200)\end{array}$ & Other \\
\hline R1 & 83JS103B & $67^{\circ} 43^{\prime} 50^{\prime \prime}$ & $160^{\circ} 01^{\prime} 32^{\prime \prime}$ & Fe-oxide stained marble & 0.5 & 1,000 & 200 & 7 & 20 & 3,000 & 30 & 650 & $1,000 \mathrm{As}, 7 \mathrm{Be}, \mathrm{G} 1,000 \mathrm{Zr}$ \\
\hline $\mathrm{R} 2$ & 83SK312A & $67^{\circ} 38^{\prime} 30^{\prime \prime}$ & $160^{\circ} 14^{\prime} 30^{\prime \prime}$ & Siliceous slate w/pyrite & 0.5 & 1,500 & 100 & 20 & 5 & 70 & 20 & 300 & $2,000 \mathrm{~V}$ \\
\hline R3 & 84JS031D & $67^{\circ} 37^{\prime} 44^{\prime \prime}$ & $160^{\circ} 18^{\prime} 40^{\prime \prime}$ & Blk phyllite $w / \mathrm{Fe}$-oxides & $\mathrm{L}$ & 500 & 50 & 300 & 10 & 700 & 20 & 5,000 & $230 \mathrm{As}^{*}, 150 \mathrm{Co}, 20 \mathrm{Sb}^{*}$ \\
\hline R4 & 83JS093A & $67^{\circ} 33^{\prime} 50^{\prime \prime}$ & $160^{\circ} 25^{\prime} 25^{\prime \prime}$ & Feldspathic gtz-chlorite schist & $\mathrm{L}$ & $\mathrm{N}$ & 200 & 500 & $\mathrm{~N}$ & 150 & $\mathrm{~L}$ & 15 & $10 \% \mathrm{Fe}, 700 \mathrm{~V}, 2,000 \mathrm{Mn}$ \\
\hline R5 & 84SK $107 \mathrm{~A}$ & $67^{\circ} 33^{\prime} 40^{\prime \prime}$ & $160^{\circ} 15^{\prime} 40^{\prime \prime}$ & Black siliceous slate/quartzite & 0.7 & 100 & 70 & 30 & 70 & 50 & 15 & 85 & $30 \mathrm{As}^{*}, 4 \mathrm{Sb}^{*}, 2,000$ \\
\hline R5 & $84 \mathrm{SK} 107 \mathrm{~B}$ & $67^{\circ} 33^{\prime} 40^{\prime \prime}$ & $160^{\circ} 15^{\prime} 40^{\prime \prime}$ & Brecciated black siliceous slate & 0.5 & 1,000 & 50 & 50 & 70 & 200 & 20 & 750 & $40 \mathrm{As}^{*}, 6 \mathrm{Sb}^{*}, 3.4 \mathrm{Cd}^{*}$ \\
\hline R6 & 83SK $273 \mathrm{C}$ & $67^{\circ} 31^{\prime} 50^{\prime \prime}$ & $160^{\circ} 25^{\prime} 30^{\prime \prime}$ & Chloritic layer in phyllite & 1 & G5,000 & 150 & 70 & $\mathrm{~N}$ & 100 & 70 & 200 & $2,000 \mathrm{Mn}, 100 \mathrm{Nb}, 5,000 \mathrm{Sr}$ \\
\hline R7 & $84 \mathrm{EK} 063$ & $67^{\circ} 42^{\prime} 54^{\prime \prime}$ & $161^{\circ} 41^{\prime} 03^{\prime \prime}$ & Vein quartz in phyllite & 0.7 & 20 & $\mathrm{~N}$ & 1,500 & $\mathrm{~N}$ & $\mathrm{~N}$ & $\mathrm{~N}$ & 75 & \\
\hline R8 & $84 \mathrm{EK} 053$ & $67^{\circ} 53^{\prime} 08^{\prime \prime}$ & $161^{\circ} 41^{\prime} 25^{\prime \prime}$ & Serpentinite & $\mathrm{N}$ & $\mathrm{N}$ & 1,500 & 5 & $\mathrm{~N}$ & 2,000 & $\mathrm{~N}$ & 130 & $\mathrm{G} 10 \% \mathrm{Mg}, 1,000 \mathrm{Mn}$ \\
\hline R9 & 84 SK055B & $67^{\circ} 54^{\prime} 28^{\prime \prime}$ & $161^{\circ} 35^{\prime} 45^{\prime \prime}$ & Serpentinite & $\mathrm{N}$ & $\mathrm{N}$ & 3,000 & 20 & $\mathrm{~N}$ & 2,000 & $\mathrm{~N}$ & 15 & $7 \% \mathrm{Fe}, \mathrm{G} 10 \% \mathrm{Mg}, 700 \mathrm{Mn}$ \\
\hline R 10 & 84SK 057A & $67^{\circ} 54^{\prime} 12^{\prime \prime}$ & $161^{\circ} 36^{\prime} 10^{\prime \prime}$ & Serpentinite & $\mathrm{N}$ & $\mathrm{N}$ & 3,000 & 7 & $\mathrm{~N}$ & 1,500 & $\mathrm{~N}$ & 10 & $10 \% \mathrm{Mg}, 300 \mathrm{Mn}$ \\
\hline R11 & 84 SK059A & $67^{\circ} 53^{\prime} 50^{\prime \prime}$ & $161^{\circ} 36^{\prime} 35^{\prime \prime}$ & Limonitic cherty limestone & 1.5 & $\mathrm{~L}$ & 20 & 100 & 100 & 300 & $\mathrm{~L}$ & 1,000 & $20 \% \mathrm{Fe}, 360 \mathrm{As}^{*}, 3.9 \mathrm{Cd} *$ \\
\hline $\mathrm{R} 12$ & $84 \mathrm{PF} 070 \mathrm{R}$ & $67^{\circ} 53^{\prime} 16^{\prime \prime}$ & $161^{\circ} 45^{\prime} 36^{\prime \prime}$ & Basalt w/pyrite and chalcopyrite & 2 & 100 & 10 & 500 & $\mathrm{~N}$ & 20 & 20 & 65 & $20 \% \mathrm{Fe}, 1,000 \mathrm{Mn}$ \\
\hline R13 & 84SK033A & $67^{\circ} 48^{\prime} 45^{\prime \prime}$ & $161^{\circ} 40^{\prime} 45^{\prime \prime}$ & Black shale & 5 & 700 & 300 & 70 & 30 & 70 & $\mathrm{~N}$ & 170 & $60 \mathrm{As}^{*}, 1.5 \mathrm{Be}$ \\
\hline R 14 & $84 \mathrm{JS} 006$ & $67^{\circ} 48^{\prime} 20^{\prime \prime}$ & $161^{\circ} 37^{\prime} 00^{\prime \prime}$ & Black shale & 3 & 700 & 300 & 50 & $\mathrm{~L}$ & 70 & 30 & $\mathrm{~N}$ & $1.5 \mathrm{Be}, 200 \mathrm{~V}$ \\
\hline R15 & 84JS014B & $67^{\circ} 47^{\prime} 20^{\prime \prime}$ & $161^{\circ} 17^{\prime} 30^{\prime \prime}$ & Carbonaceous shale w/ Fe-oxides & 3 & 500 & 200 & 50 & 10 & 30 & 10 & $\mathrm{~N}$ & $10 \mathrm{~B}, 1.5 \mathrm{Be}$ \\
\hline R16 & 84JS030B & $67^{\circ} 43^{\prime} 50^{\prime \prime}$ & $161^{\circ} 44^{\prime} 00^{\prime \prime}$ & Silica-pyrite alteration & 5 & 700 & 20 & 200 & 30 & 50 & 50 & 100 & $20 \% \mathrm{Fe}, 200 \mathrm{As}$ \\
\hline R16 & $84 \mathrm{RB} 103 \mathrm{~B}$ & $67^{\circ} 43^{\prime} 50^{\prime \prime}$ & $161^{\circ} 44^{\prime} 00^{\prime \prime}$ & Massive pyrite in shale & 2 & 300 & 50 & 100 & $\mathrm{~N}$ & 100 & 50 & 10 & $\mathrm{G} 20 \% \mathrm{Fe}$ \\
\hline R17 & 84SK089A & $67^{\circ} 41^{\prime} 40^{\prime \prime}$ & $161^{\circ} 45^{\prime} 00^{\prime \prime}$ & Black phyllite with ironstone & $\mathrm{L}$ & 300 & 50 & 50 & $\mathrm{~N}$ & 70 & 200 & 180 & 50 As*, $10 \% \mathrm{Fe}, 1,500 \mathrm{Mn}$ \\
\hline R18 & $84 \mathrm{EK} 055$ & $67^{\circ} 38^{\prime} 38^{\prime \prime}$ & $161^{\circ} 25^{\prime} 20^{\prime \prime}$ & Vein quartz with pyrite & 3 & 100 & 20 & 3,000 & $\mathrm{~N}$ & 300 & 30 & 20 & $100 \mathrm{As}^{*}$ \\
\hline R19 & $84 \mathrm{JS} 028 \mathrm{E}$ & $67^{\circ} 38^{\prime} 00^{\prime \prime}$ & $161^{\circ} 24^{\prime} 45^{\prime \prime}$ & Quartz vein in limestone & 3 & 30 & 10 & 50 & $\mathrm{~N}$ & 15 & 500 & 46,000 & $420 \mathrm{Cd}^{*}$ \\
\hline $\mathrm{R} 20$ & $84 \mathrm{RB} 308$ & $67^{\circ} 36^{\prime} 17^{\prime \prime}$ & $161^{\circ} 30^{\prime} 14^{\prime \prime}$ & Copper-stained carbonate & 0.5 & 30 & $\mathrm{~N}$ & 20,000 & $\mathrm{~N}$ & 20 & 10 & 25 & $2 \mathrm{Be}, 500 \mathrm{Mn}$ \\
\hline R 21 & 84SK 092B & $67^{\circ} 35^{\prime} 58^{\prime \prime}$ & $161^{\circ} 43^{\prime} 00^{\prime \prime}$ & Quartz-pyrite veins in phyllite & 3 & $\mathrm{~L}$ & $\mathrm{~N}$ & 100 & $\mathrm{~N}$ & 70 & 150 & 5 & $190 \mathrm{As}^{*}, 30 \mathrm{Sb} *$ \\
\hline
\end{tabular}


Table 3.--Selected anomalous stream sediment samples from the central and northwestern Baird Mountains quadrangle. Results are of semiquantitative emission spectrography. All elements reported in parts per million, except as noted. G, greater than the value shown; L, detected, but below the level of determination; $\mathrm{N}$, not detected at limit of detection (limits given in parentheses at column heading)

\begin{tabular}{|c|c|c|c|c|c|c|c|c|c|c|c|c|}
\hline $\begin{array}{l}\text { Loc- } \\
\text { ation }\end{array}$ & Sample & Latitude & Longitude & $\begin{array}{c}\mathrm{Ag} \\
(.5)\end{array}$ & $\begin{array}{c}\mathrm{Ba} \\
(10)\end{array}$ & $\begin{array}{c}\mathrm{Cr} \\
(10)\end{array}$ & $\begin{array}{l}\mathrm{Cu} \\
(5)\end{array}$ & $\begin{array}{l}\text { Mo } \\
\text { (5) }\end{array}$ & $\begin{array}{l}\mathrm{Ni} \\
(5)\end{array}$ & $\begin{array}{c}\mathrm{Pb} \\
(10)\end{array}$ & $\underset{(200)}{\mathrm{Zn}}$ & Other \\
\hline S1 & 83 ЕК093 & $67^{\circ} 42^{\prime} 40^{\prime \prime}$ & $160^{\circ} 07^{\prime} 45^{\prime \prime}$ & 0.5 & 1,000 & 100 & 70 & 10 & 100 & 30 & 500 & $5 \% \mathrm{Fe}$. \\
\hline S2 & 83 ЕК 089 & $67^{\circ} 40^{\prime} 40^{\prime \prime}$ & $160^{\circ} 07^{\prime} 55^{\prime \prime}$ & $\mathrm{N}$ & 1,000 & 70 & 30 & 15 & 150 & 15 & 300 & $5 \% \mathrm{Fe}, 2,000 \mathrm{Mn}$. \\
\hline S3 & 83 EK086 & $67^{\circ} 39^{\prime} 03^{\prime \prime}$ & $160^{\circ} 13^{\prime} 10^{\prime \prime}$ & $\mathrm{N}$ & 700 & 70 & 70 & 10 & 70 & 20 & 200 & $3 \% \mathrm{Fe}, 300 \mathrm{~B}$. \\
\hline S4 & $83 \mathrm{EK} 058$ & $67^{\circ} 33^{\prime} 35^{\prime \prime}$ & $160^{\circ} 21^{\prime} 45^{\prime \prime}$ & 0.5 & 1,000 & 70 & 50 & 15 & 70 & 15 & 200 & $3 \% \mathrm{Fe}, 150 \mathrm{Y}$ \\
\hline S5 & 83 EK 060 & $67^{\circ} 33^{\prime} 25^{\prime \prime}$ & $160^{\circ} 22^{\prime} 50^{\prime \prime}$ & 3 & 1,000 & 70 & 50 & 10 & 70 & 15 & $\mathrm{~L}$ & $3 \% \mathrm{Fe}$ \\
\hline $\mathrm{S} 6$ & 83PF 105 & $67^{\circ} 32^{\prime} 20^{\prime \prime}$ & $160^{\circ} 24^{\prime} 26^{\prime \prime}$ & 5 & 1,000 & 70 & 50 & 15 & 70 & 500 & $\mathrm{~N}$ & $5 \% \mathrm{Fe}$. \\
\hline S7 & 83 EK055 & $67^{\circ} 31^{\prime} 50^{\prime \prime}$ & $160^{\circ} 24^{\prime} 30^{\prime \prime}$ & 1 & 2,000 & 70 & 70 & 20 & 100 & 30 & 500 & $5 \% \mathrm{Fe}$. \\
\hline S8 & 83PF 108 & $67^{\circ} 31^{\prime} 20^{\prime \prime}$ & $160^{\circ} 22^{\prime} 20^{\prime \prime}$ & $\mathrm{L}$ & 500 & 200 & 50 & $\mathrm{~N}$ & 100 & 200 & 300 & $7 \% \mathrm{Fe}$. \\
\hline S9 & 84PF161 & $67^{\circ} 30^{\prime} 32^{\prime \prime}$ & $161^{\circ} 29^{\prime} 24^{\prime \prime}$ & $\mathrm{L}$ & 2,000 & 100 & 70 & 15 & 70 & 30 & $\mathrm{~L}$ & $3 \% \mathrm{Fe}, 70 \mathrm{Y}$. \\
\hline S10 & 84PF061 & $67^{\circ} 57^{\prime} 26^{\prime \prime}$ & $161^{\circ} 43^{\prime} 18^{\prime \prime}$ & 2 & 1,000 & 700 & 20 & $\mathrm{~N}$ & 70 & 20 & $\mathrm{~N}$ & $100 \mathrm{~B}$. \\
\hline S11 & 84 PF063 & $67^{\circ} 54^{\prime} 45^{\prime \prime}$ & $161^{\circ} 26^{\prime} 40^{\prime \prime}$ & 2 & 700 & 200 & 50 & $\mathrm{~N}$ & 100 & 10 & 300 & \\
\hline $\mathrm{S} 12$ & 84PF 070 & $67^{\circ} 53^{\prime} 16^{\prime \prime}$ & $161^{\circ} 45^{\prime} 36^{\prime \prime}$ & 1 & 300 & 150 & 700 & L & $\mathrm{L}$ & 20 & $\mathrm{~N}$ & $15 \% \mathrm{Fe}$. \\
\hline S13 & 84 ВT028 & $67^{\circ} 53^{\prime} 46^{\prime \prime}$ & $161^{\circ} 46^{\prime} 34^{\prime \prime}$ & $\mathrm{N}$ & 300 & G,5000 & 30 & $\mathrm{~N}$ & 200 & 10 & $\mathrm{~N}$ & $30 \mathrm{Co}, 3 \% \mathrm{Fe}, 700 \mathrm{Mn}$ \\
\hline S14 & $84 \mathrm{PF} 001$ & $67^{\circ} 48^{\prime} 34^{\prime \prime}$ & $161^{\circ} 38^{\prime} 54^{\prime \prime}$ & 1 & 2,000 & 150 & 50 & 15 & 70 & 70 & 300 & $1,500 \mathrm{Mn}$. \\
\hline S15 & $84 \mathrm{RB} 003$ & $67^{\circ} 49^{\prime} 13^{\prime \prime}$ & $161^{\circ} 34^{\prime} 44^{\prime \prime}$ & 1 & 1,500 & 150 & 50 & 10 & 70 & 70 & 500 & $1,500 \mathrm{Mn}$. \\
\hline S16 & $84 \mathrm{PF} 002$ & $67^{\circ} 50^{\prime} 06^{\prime \prime}$ & $161^{\circ} 38^{\prime} 40^{\prime \prime}$ & 1.5 & 700 & 150 & 20 & 7 & 50 & 50 & $\mathbf{N}$ & $1.5 \mathrm{Be}$. \\
\hline S17 & $84 \mathrm{RB} 002$ & $67^{\circ} 48^{\prime} 12^{\prime \prime}$ & $161^{\circ} 39^{\prime} 36^{\prime \prime}$ & 3 & 700 & 200 & 30 & 10 & 70 & 50 & $\mathrm{~N}$ & $100 \mathrm{Nb}$. \\
\hline S18 & 84PF 082 & $67^{\circ} 48^{\prime} 00^{\prime \prime}$ & $161^{\circ} 42^{\prime} 48^{\prime \prime}$ & 1 & 500 & 200 & 50 & 10 & 150 & 30 & 500 & $1,500 \mathrm{Mn}, 10 \mathrm{C} \mathrm{Nb}$ \\
\hline S19 & 84 PF076 & $67^{\circ} 48^{\prime} 39^{\prime \prime}$ & $161^{\circ} 58^{\prime} 54^{\prime \prime}$ & $\mathrm{N}$ & 300 & 700 & 200 & $\mathrm{~N}$ & 50 & 20 & 500 & $1,500 \mathrm{Mn}$ \\
\hline $\mathrm{S} 20$ & $84 \mathrm{EK} 024$ & $67^{\circ} 45^{\prime} 36^{\prime \prime}$ & $161^{\circ} 22^{\prime} 36^{\prime \prime}$ & 0.5 & 700 & 100 & 70 & $\mathrm{~N}$ & 300 & 20 & 1,000 & $2 \mathrm{Be}, 70 \mathrm{Co}, 1,500 \mathrm{Mn}$ \\
\hline S21 & $84 \mathrm{RB} 103$ & $67^{\circ} 43^{\prime} 56^{\prime \prime}$ & $161^{\circ} 44^{\prime} 05^{\prime \prime}$ & $\mathrm{L}$ & 2,000 & 100 & 50 & 10 & 50 & 30 & 200 & $3 \% \mathrm{Fe}, 500 \mathrm{Mn}$. \\
\hline S22 & $84 \mathrm{RB} 036$ & $67^{\circ} 36^{\prime} 39^{\prime \prime}$ & $161^{\circ} 23^{\prime} 36^{\prime \prime}$ & $\mathrm{N}$ & 70 & 70 & 200 & $\mathbf{N}$ & 30 & 100 & $\mathrm{~N}$ & G10\% Mg. \\
\hline S23 & 84 PF017 & $67^{\circ} 44^{\prime} 12^{\prime \prime}$ & $161^{\circ} 34^{\prime} 44^{\prime \prime}$ & $\mathbf{N}$ & 300 & 150 & 20 & $\mathrm{~N}$ & 50 & 200 & $\mathrm{~N}$ & $3 \% \mathrm{Fe}, 300 \mathrm{Mn}$. \\
\hline
\end{tabular}

Table 2 is a list of rock grab samples collected as representative of dominant lithologies at a sample site or because of visible sulfides, oxidation, or alteration (as noted). Table 3 is a list of streamsediment samples that are composites of $3-4 \mathrm{~kg}$ of -80 mesh material collected from sites along a $10-$ $\mathrm{m}$-stretch of stream. Sediment samples represent small drainage basins only a few square $\mathrm{km}$ in area. All rock and stream-sediment samples were analyzed by 31-element-semiquan titative-emission spectrography, and atomic-absorption spectroscopy for $\mathrm{As}, \mathrm{Zn}, \mathrm{Cd} \mathrm{Bi}$, and $\mathrm{Sb}$. Table 4 lists previously reported geochemical anomalies.

The geology consists of sequences of Paleozoic marine carbonate and pelitic rocks, and marine and nonmarine clastic rocks variably metamorphosed to marble, phyllite and schist (Brosge and others, 1967; Mayfield and others, 1983), and juxtaposed by thrust faulting. Mafic and felsic volcanic and vol- caniclastic rocks are locally intercalated in parts of some Paleozoic rock sequences (Tailleur and others, 1977). Intermediate igneous rocks of Precambrian age (Mayfield and others, 1980) undorlie the Paleozoic sedimentary rocks at Hub Mountain. Mesozoic marine sedimentary rocks and mafic volcanic rocks have been tectonically emplared above the Paleozoic rocks (Tailleur and others, 1967; Mayfield and others, 1983).

In the central part of the quadrangle (fig. 9), Paleozoic rocks consist of interlayered gray, black, and silvery-green phyllites, siliceous gray to black phyllite and slate, quartzose sandstone, feldspathic quartz-chlorite semischist, marble, and dolostone. No rock units have been formally named in this area, but many of the sandstones and phyllites are lithologically similar to components of the Endicott Group (Tailleur and others, 1967). Rock samples from locations R2, R3, and R5 (fig. 9) $\varepsilon^{\text {ree from a }}$

Table 4.--Previously reported geochemical anomalies

\begin{tabular}{|c|c|c|c|}
\hline Locatio & $\begin{array}{l}\text { Sample } \\
\text { type }\end{array}$ & Element & Reference \\
\hline 1 & Stream-s & $\mathrm{Cu}$ & Dege \\
\hline 2 & Stream-sediment & $\mathrm{Ag}, \mathrm{Zn}$ & eck and others, 1984. \\
\hline 3 & Stream-sediment & $\begin{array}{l}\mathrm{Ag}, \mathrm{Cu}, \\
\mathrm{Pb}, \mathrm{Zn}\end{array}$ & eck and others, 1984. \\
\hline 4 & Stream- & $\mathrm{Ag}, \mathrm{Zn}$ & Elle \\
\hline 5 & Stream-sediment & $\mathrm{Ag}, \mathrm{Cu}$ & Elle \\
\hline 6 & Stream-sediment & $\mathrm{Cu}$ & s, 1984. \\
\hline 7 & Rock & $\mathrm{Cu}$ & Degenhart and others, 1978. \\
\hline 8 & Rock & $\mathrm{Cu}$ & Brosge and others, 1967. \\
\hline
\end{tabular}




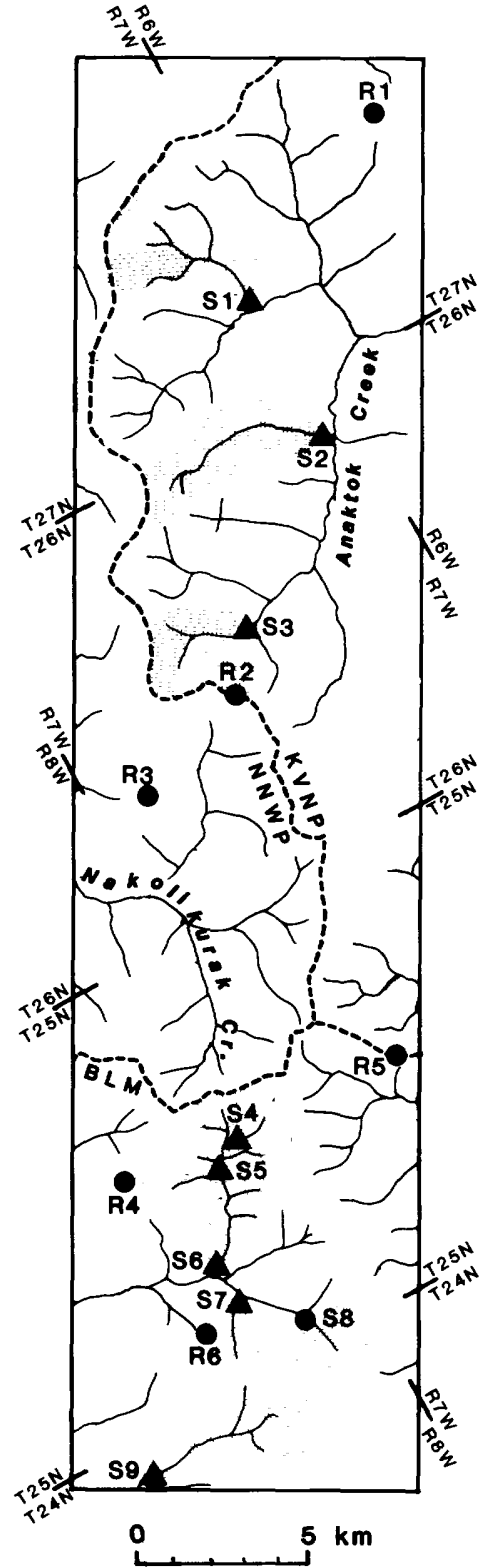

Figure 9.--Location of anomalous rock and stream sediment samples in the central Baird Mountains quadrangle. Shaded areas are basins drained by each sampled stream. Rock sample locations shown by solid circles; stream sediment sample locations shown by solid triangles.

distinctive black siliceous slate or siliceous phyllite and contain anomalous values of $\mathrm{Zn}, \mathrm{Mo}, \mathrm{As}, \mathrm{Sb}, \mathrm{Ag}$, $\mathrm{V}$, and $\mathrm{Ba}$. Many contain high values of $\mathrm{Cu}, \mathrm{Ni}, \mathrm{Cd}$, and Co. Also in this trend, gray marble intercalated with gray quartz-mica schist, and two varieties of chloritic feldspathic and calcareous semischist yielded anomalous values for some elements. Nine stream-sediment samples in this area contained high . values of $\mathrm{Ag}, \mathrm{Ba}, \mathrm{Cu}, \mathrm{Mo}, \mathrm{Mn}, \mathrm{Pb}$, and $\mathrm{Zn}$. The only

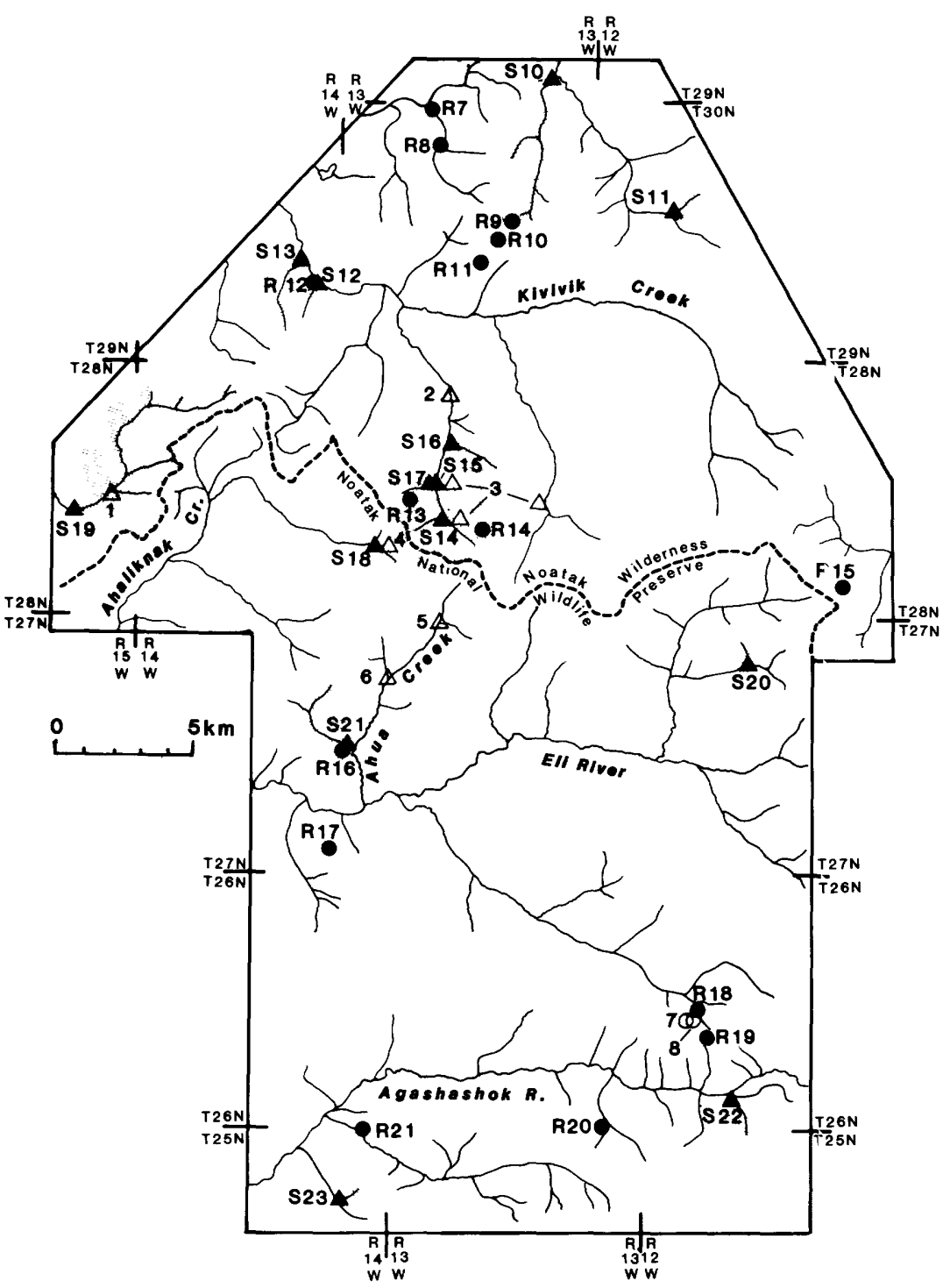

Figure 10.--Location of anomalous rock ard stream sediment samples in the northwestern Baird Mountains quadrangle. Rock and stream-sediment samples and drainage basins shown as indicated in figure 9. Previously reported rock anomalies shown by open circles; previously reported stream sediment samples shown by open triangles.

previously reported mineral occurrence from this area was a quartz-chalcopyrite vein in groenstone (Brosge and others, 1967; Cobb, 1972), which could not be relocated in 1984 .

In the northwestern part of the quadrangle (fig. 10), the rocks consist of structurally jux taposed sequences of Paleozoic silvery-green pelitic and gray quartzose marine and nonmarine clastic rocks, black carbonaceous and siliceous shales, gieen tuff- 
aceous rocks, gray, bedded, fossiliferous, and (or) cherty limestones and dolostones, and Mesozoic mafic volcanic rocks. Sixteen rock samples and 13 stream-sediment samples from this area contained anomalously high values in various elements. Six rock samples are black carbonaceous shale or phyllite with high $\mathrm{Ag}, \mathrm{As}, \mathrm{Ba}, \mathrm{Be}$, and $\mathrm{Fe}$ values, and moderate $\mathrm{Pb}$ and $\mathrm{Zn}$ values. Samples from localities $\mathrm{R} 13$, R14, and R15, and stream-sediment samples from localities S14-S18 are from the Kilyaktalik Peaks area south of Kivivik Creek, where high geochemical values for stream-sediment samples were reported by Ellersieck and others (1984). Black phyllite with ironstone nodules (locality R17) from the Eli River area contains high $\mathrm{Pb}, \mathrm{Fe}, \mathrm{Mn}$, and $\mathrm{As}$ values.

Pyritic massive sulfide was found at locality R16, informally named the Ahua occurrence. This occurrence consists of a few small exposures of very-fine grained to botryoidal massive pyrite and silica-pyrite alteration in an area up to several hundred meters in width containing Fe-oxide stained, bleached, or carbonaceous shale. A sample of massive pyrite (84RB103B) contains anomalous Ag values with moderate $\mathrm{Cu}$ and $\mathrm{Pb}$ values. Another sample, consisting of gray silica-pyrite-altered rock (84JS30 B), contains higher $\mathrm{Ag}, \mathrm{As}, \mathrm{Ba}$, and $\mathrm{Zn}$ values with similar amounts of other metals as those in sample 84RB103B. Downstream from this occurrence, sample $\mathrm{S} 21$ contains high $\mathrm{Ba}$, and moderate $\mathrm{Zn}$ and $\mathrm{Fe}$ values, but little other indication of mineralization. Stream-sediment samples from localities S11 and S20 contain anomalous values of Ag, $\mathrm{Ni}$, and $\mathrm{Zn}$, and drain similar carbonaceous black shales. These black shales are unnamed and of unknown age in the Baird Mountains quadrangle but are lithologically similar to the Kuna Formation of Carboniferous age, which hosts massive $\mathrm{Zn}-\mathrm{Pb}-\mathrm{Ag}$ mineralization in the Noatak district, approximately $80-100 \mathrm{~km}$ to the northwest.

Samples from the Kivivik Creek area (locality R12; fig. 10) include mafic volcanic rocks with high values of $\mathrm{Cu}, \mathrm{Fe}$, and $\mathrm{Ag}$, marked by a prominent orange- and red-stained zone (approximately $50 \mathrm{~m} \mathrm{X}$ $100 \mathrm{~m}$ ) containing clay, Fe-oxide, and epidote alteration of basalt, as well as disseminated pyrite and chalcopyrite. A stream-sediment sample (S12) from the creek draining the occurrence has anomalous $\mathrm{Ag}, \mathrm{Cu}$, and $\mathrm{Fe}$ values. Nearby stream-sediment samples ( $\mathrm{S} 13$ and S19) are also from drainages underlain by basalt, and have high $\mathrm{Co}, \mathrm{Cr}, \mathrm{Cu}, \mathrm{Mn}$, and $\mathrm{Zn}$ values.

Some carbonate rocks from this area (fig. 10) also yielded high metal values. One sample of limonitic limestone with chert nodules and crinoid and coral fragments (locality R11), lithologically similar to the Mississippian Kogruk Formation, contains high $\mathrm{Ag}, \mathrm{As}, \mathrm{Cd}$, and Mo values, as well as 0.1 percent $\mathrm{Zn}$. Malachite- and azurite-stained limestone (locality R20) contains 2 percent $\mathrm{Cu}$. One stream-sediment sample (locality S22) with high $\mathrm{Cu}$ and $\mathrm{Pb}$ values drains an area of carbonate rocks.

Serpentinites occurring along faults yielded high $\mathrm{Cr}, \mathrm{Ni}$, and $\mathrm{Mn}$ values. At locality $\mathrm{R} 8$, they occur in a zone of gray limestone, and at localities $\mathrm{R} 9$ and R10, they occur between mafic greenstones and calcareous crinoid-bearing sandstone.

Rock samples from localities R7, R18, R19, and R21 are from quartz lenses and veins in gray and green phyllite probably correlative with the Devonian Hunt Fork Shale. The phyllites contain up to 10 percent quartz in lenses and discontinuous veins, which may be sulfide-bearing (dorninantly pyrite). The samples have high $\mathrm{Ag}, \mathrm{As}, \mathrm{Cd}, \mathrm{Mn}, \mathrm{Pb}$, and $\mathrm{Zn}$ values; galena and sphalerite were identified in the sample from locality $\mathrm{R} 19$, which contained 4.6 percent $\mathrm{Zn}, 420 \mathrm{ppm} \mathrm{Cd}$, and $500 \mathrm{ppm} \mathrm{Pb}$.

Sediment samples S10 and S23 are from streams draining mixed marine clastic and carbonate rocks; the source of anomalous metal values has not been identified.

Localities listed in this report are interesting because they are clustered and because of lithologic affinities with rocks from known mineral deposits and occurrences nearby in the Noatak district. Detailed mapping and sampling are planned for 1985 .

\section{REFERENCES CITED}

Brosge, W. P., Reiser, H. N., and Tailleur, I. L., 1967, Copper analysis of selected samples, southwestern Brooks Range, Aleska: U.S. Geological Survey Open-File Report 274, 1 sheet, scale 1:1,000,000.

Cobb, E. H., 1972, Metallic mineral reso'rces of the Baird Mountains quadrangle, Aleska: U.S. Geological Survey Miscellaneous Field Studies Map MF 386, 1 sheet, scale 1:250,000.

Degenhart, C. E., Griffis, R. J., McOuat, J. F., and Bigelow, C. G., 1978, Mineral studies of certain ANCSA 17 (d)(2) lands in Alaska, volume 1: U.S. Bureau of Mines Open-File Report 103-78, 546 p.

Ellersieck, Inyo, Blanchaid, D. C., Mayfield, C. F., and Tailleur, I. L., 1984, Kivivik Creek: a possible zinc-lead-silver occurrence in the Kuna Formation, western Baird Mountains, Alaska, in Coonrad, W. L., ed., U.S. Geological Survey in Alaska-Accomplishments during 1981: U.S. Geological Survey Circular 868, p. 16-17

Grybeck, Donald, McDanal, S. K., Cooley', E. F., and O'Leary, R. M., 1982, Map of anomalous rock samples and histograms of trace metals in rocks of the Survey Pass quadranrle, Brooks Range, Alaska: U.S. Geological S'urvey Miscellaneous Field Studies Map MF 1176-E, scale $1: 250,000$.

Mayfield, C. F., Silberman, M. L., ard Tailleur, I. L., 1982, Precambrian metamorphic rocks from the Hub Mountain terrane, Baird Mountains, Alaska; in Coonrad, W. L., The 
United States Geological Survey in AlaskaAccomplishments during 1980: U. S. Geological Survey Circular 844, p. 18-22.

Mayfield, C. F., Tailleur, I. L., Ellersieck, Inyo, 1983, Stratigraphy, structure and palinspastic synthesis of the western Brooks Range, northwestern Alaska: U.S. Geological Survey OpenFile Report 83-779, 53 p.

Plahuta, J. T., 1978, Geologic map and cross sections of the Red Dog Prospect, DeLong Mountains, northwestern Alaska: U.S. Bureau of Mines Open-File Report 65-68, 7 p.

Smith, P. S., 1911, The Squirrel River placers: U.S. Geological Survey Bulletin 480, p. 306-319.

Smith, P. S., 1913, The Noatak-Kobuk region, Alaska: U.S. Geological Survey Bulletin 536, p. 133-168.

Tailleur, I. L., Brosge, W. P., and Reiser, H. N., 1967, Palinspastic analysis of Devonian rocks in northwestern Alaska, in Oswald, D. H., ed., International symposium on the Devonian System: Alberta Society of Petroleum Geologists, v. 2, p. 1345-1361.

Tailleur, I. L., Mayfield, C. F., and Ellersieck, I. E., 1977, Late Paleozoic sedimentary sequence, southwestern Brooks Range, in Blean, K. M., ed., The United States Geological Survey in Alaska-Accomplishments during 1976: U.S. Geological Survey Circular 751-B, p. B24.

Reviewers: S. W. Nelson and F. H. Wilson

\section{OPHIOLITIC ULTRAMAFIC ROCKS OF THE JADE MOUNTAINS-COSMOS HILLS AREA, SOUTHWESTERN BROOKS RANGE}

\section{Robert A. Loney and Glen R. Himmelberg}

The scattered outcrops of ultramafic rocks in the Jade Mountains-Cosmos Hills area are the only exposures of the ultramafic part of the YukonKoyukuk ophiolite on the northern flank of the Yukon-Koyukuk Basin (fig. 11; Patton and others, 1977). The ophiolite, as defined by Patton and others (1977) and well exposed in the Kanuti River region on the southeast flank of the basin, typically consists of a mafic-ultramafic unit thrust over a pillow basalt-chert unit containing fossils of Mississippian to Triassic age. The thrust contact dips generally inward toward the center of the Yukon-Koyukuk Basin (that is, southward on the north flank and northwestward on the southeast flank) (Patton and Miller, 1970; Loney and Himmelberg, 1985). Although the pillow basaltchert unit crops out widely on the north flank of the basin, the structurally higher mafic-ultramafic unit is exposed only in a few scattered outcrops near the west end, in the Jade Mountains-Cosmos Hills area (fig. 11). A prominent, linear, gravity high, located along the northern edge of the Yukon-Koyukuk Basin east of the Cosmos Hills, suggests that the mafic-ultramafic unit may be buried benoath the Cretaceous sedimentary rocks (Barnes, 1970; W. W. Patton, Jr., USGS, written commun., 1985).

The ultramafic rocks of the Jade Mountains are in contact on the north with metamorphosed pillow basalt along a south-dipping thrust fault, and in contact on the south with surficial deposits and Cretaceous sedimentary rocks (fig. 11). This relationship is typical of the Yukon-Koyukuk ophiolite, except for the absence of the cumulus gabbro-ultramafic unit (the upper part of the mafic-ultramafic unit) that may be buried beneath the Cretaceous sedimentary rocks and surficial deposits to the south. Although the ultramafic rocks are extensively serpentinized, especially along the fault zones, enough of the primary mineral assemblages and fabric survive to identify the dominant rock type as harzburgite tectonite. The ultramafic rocks, therefore, represent the lower part and mantle suite of the mafic-ultramafic unit of the ophiolite (Loney and Himmelberg, 1984, 1985).

In contrast to the Jade Mountains, tre occurrence of the ultramafic rocks in the Cosmos Hills area is not typical of the Yukon-Koyuku' ophiolite. Here, the mafic-ultramafic unit is represented by tabular bodies of serpentinite as much as $130 \mathrm{~m}$ thick and $8 \mathrm{~km}$ long, distributed around tre metamorphic core of the Cosmos Hills anticline. Asbestos Mountain, a tabular body of serpentinite resting on the schist along the axis of the Cosmos Hills anticline, is interpreted as a klippe or remnant of a thrust sheet of ultramafic rocks that once covered the core of the anticline (Patton and others, 1968; Hitzman and others, 1982). No primary minerals have been found, except fine, scattered grains of chromite, which suggests the original rocks were either dunite or harzburgite, or both. A likel." source for these rocks would be the ophiolite. In addition to serpentinization, the ultramafic rocks of the Cosmos Hills have undergone considerable ceformation and recrystallization. Thin bodies of sheared serpentinite included in the limbs of folds ard thrust planes indicate much plastic muvement of the original rocks, making it difficult to interpret their present setting. The serpentinite body at Asbestos Mountain is a hard, massive, antigorite rock that apparently recrystallized from sheared serpentinite.

The occurrence of nephrite jade in the Kobuk River area was reported as early as 1884 (Cantwell, 1884). This area is one of three sources for nephrite jade in the United States; the other occurrences are in California and Wyoming. Most of the nephrite at Kobuk River occurs as pebbles, cobbles, and boulders in the tributaries to the north, such as Jade Creek, Shungnak River, and Dahl Creek (Anderson, 1944). Howev's, lode deposits of nephrite jede have been found only at Jade Mountain. 


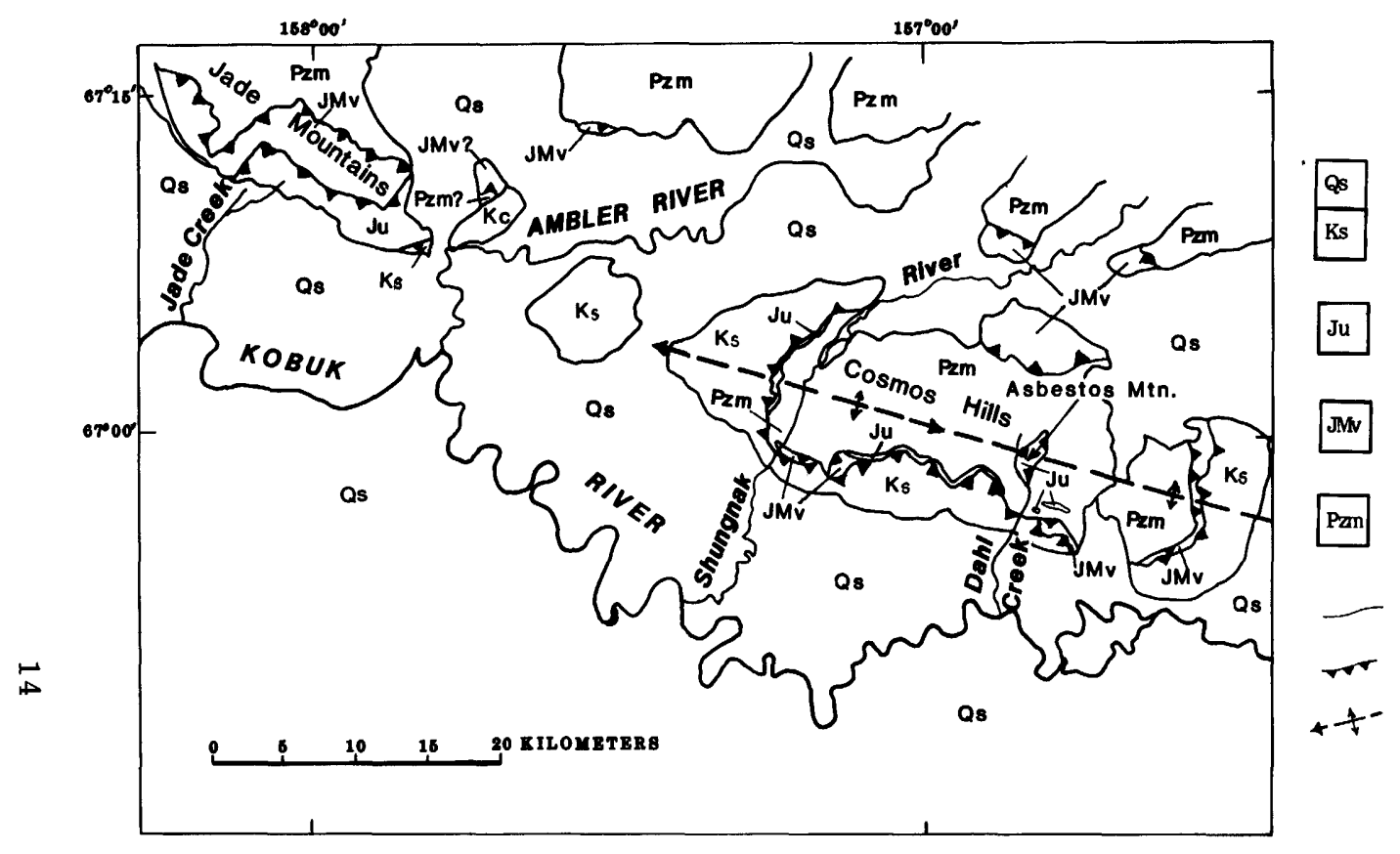

EXPLANATION

Surficial deposits (Quaternary)

Sedimentary rocks (Cretaceous)--Inc lude conglamerate, sandstone, and mudstone

Ul tramafic rocks (Jurassic)--Include harzburgite and serpentinite

Volcanic rocks (Jurassic to Mississippian)--Inelude pillow basalt and associated radiolarian chert

Metamorphic rocks (Paleozoic)--Inelude phyllite, schist and metal imestone

Contact

Thrust fault; teeth on upper plate

Trace of anticline showing direction of plunge

(Cosmos Hills)

Figure 11.--Generalized geology of the Jade Mountains-Cosmos Hills area, modified from Patton and others (1968). 
The lode nephrite jade deposits at Jade Mountain occur in "rodingite" reaction zones in and around tectonic inclusions of country rock in sheared serpentinite. The deposits closely resemble the California nephrite jade deposits that occur as one of the products of low-temperature metasomatic reaction between serpentinite and more silicic rock during serpentinization (Chesterman, 1951; Crippen, 1951; Coleman, 1967). According to Coleman (1967), the metasomatic alteration involves loss of silica in serpentinite and accompanying enrichment of calcium and magnesium in the reaction zone. Preliminary work indicates that Jade Mountain nephrite was probably derived from alteration of tectonic inclusions of pelitic schist or similar metasedimentary rock. This is in agreement with Coleman (1967) that tremolite-actinolite (nephrite) is a product of metasomatism of sedimentary and igneous rocks more silicic than the mafic igneous rocks that are the protoliths of classic rodingites.

\section{REFERENCES CITED}

Anderson, Eskil, 1944, Mineral occurrences other than gold deposits in northwestern Alaska: Territory of Alaska, Department of Mines Pamphlet 5-R, $48 \mathrm{p}$.

Barnes, D. F., 1970, Gravity and other geophysical data from northern Alaska, in Proceedings of the Geological Seminar on the North Slope of Alaska: American Association of Petroleum Geologists, Pacific Section, p. I 1-I 19.

Cantwell, J. C., 1884, A narrative account of the exploration of the Kowak (Kobuk) River, Alaska, in Healy, M. A., 1889, Report of the cruise of the revenue marine steamer Corwin in the Arctic Ocean in the year 1884: Washington, D.C., Government Printing Office, p. 47-74.

Chesterman, C. W., 1951, Nephrite in Marin County, California: State of California, Division of Mines Special Report 10-B, 11 p.

Coleman, R. G., 1967, Low-temperature reaction zones and alpine ultramafic rocks in California, Oregon, and Washington: U.S. Geological Survey Bulletin 1247, 49 p.

Crippen, R. A., Jr., 1951, Nephrite jade and associated rocks of the Cape San Martin region, Monterey County, California: State of California, Division of Mines Special Report 10-A, $14 \mathrm{p}$.

Hitzman, M. W., Smith, T. E., and Proffett, J. M., 1982, Bedrock geology of the Ambler district, southwestern Brooks Range, Alaska: State of Alaska, Division of Geological and Geophysical Surveys Geologic Report 75, map.

Loney, R. A., and Himmelberg, G. R., 1984, Distribution and character of the peridotite-layered gabbro complex of the southeastern YukonKoyukuk ophiolite belt, Alaska (abs.): Geological Society of America, Cordilleran
Section, Annual Meeting, Anchorroge, Abstracts with Programs 1984, v. 16, no. 5, p. 319.

Loney, R. A., and Himmelberg, G. R., 1985, Distribution and character of the peridotite-layered gabbro complex of the southeastern YukonKoyukuk ophiolite belt, Alaska, in BartschWinkler, Susan, and Reed, K. M., eds., The United States Geological Survey in AlaskaAccomplishments during 1983: U.S. Geological Survey Circular 945, p. 46-48.

Patton, W. W., Jr., and Miller, T. P., 1970, Preliminary geologic investigations in the Kanuti River region, Alaska: U.S. Geological Survey Bulletin 1312-J, p. J1-J10.

Patton, W. W., Jr., Miller, T. P., and Tailleur, I. L., 1968, Regional geologic map of the Shungnak and southern part of the Ambler River quadrangles, Alaska: U.S. Geological Survey Miscellaneous Geologic Investigations Map I554.

Patton, W. W., Jr., Tailleur, I. L., Brosgé, W. P., and Lanphere, M. A., 1977, Preliminary report on the ophiolites of northern and western Alaska, in Coleman, R. G., and Irwin, W. P., eds., North American Ophiolites: State of Oregon, Department of Geology and Mineral Industries Bulletin 95, p. 51-57.

Reviewers: A. B. Ford and W. W. Patton, J?.

\section{SEDIMENTOLOGY OF MEANDERING-STREAM CYCLES. UPPER PART OF THE EAR PEAK MEMBER OF THE KANAYUT CONGLOMERATE, CENTRAL BROOKS RANGE}

\section{Thomas E. Moore and Tor H. Nilsen}

The Upper Devonian and Lower Mississippian(?) Kanayut Conglomerate, one of the most extensive fluvial units in North America, crops out along the crest of the Brooks Range over an eastwest distance of $950 \mathrm{~km}$ and a north-south distance of $65 \mathrm{~km}$. In the central Brooks Range, the. Kanayut Conglomerate is as thick as $2,624 \mathrm{~m}$ and is divided into three members (Nilsen and Moore, 1984). These are, in ascending order, the Ear Peal- Member (meandering-stream deposits), Shainin Lake Member (braided-stream deposits), and Stuver Member (meandering-stream deposits). A coars?-grained delta, of which the Kanayut Conglorrerate is interpreted to be the middle nonmarine cart, prograded southwestward during the Late Devonian and subsequently retreated during Late Devcnian and Early Mississippian time (Nilsen, 1981).

The distribution, depositional facies, tectonic significance, and regional sedimentologic variations within the Kanayut Conglomerate have been reported in Nilsen (1981), Nilsen and Moore (1982), and Moore and Nilsen (1984). The purpose of this report 
Table 5.--Summary of sedimentologic characteristics of channelized lower parts of eight thinning- and fining-upward cycles in measured sections. NM, Not measured; NP, Not present; N, number of measurements; m, mean value;

$\lambda$, standard deviation; $*$, except cycles $2-8$ in section $E$

\begin{tabular}{|c|c|c|c|c|c|c|}
\hline \multirow[t]{2}{*}{ CRITERIA } & \multicolumn{5}{|c|}{ SECTION } & \multirow[t]{2}{*}{$\begin{array}{l}\text { CUMULATIVE } \\
\text { PALEOCURRENT }\end{array}$} \\
\hline & A & B & C & $\mathrm{D}$ & $\mathbf{E}$ & \\
\hline \multicolumn{7}{|l|}{ CYCLE 8} \\
\hline Thickness & NP & $3.00 \mathrm{~m}$ & NP & NP & NP & \\
\hline Maximum clast size & NP & $6 \mathrm{~cm}$ & NP & NP & NP & \\
\hline Basal strata eroded into: & NP & shale & NP & NP & NP & \\
\hline Thickest bed & NP & $2.00 \mathrm{~m}$ & NP & NP & NP & \\
\hline Paleocurrent $m$ and $\lambda$ & NP & $138^{\circ} ; 1$ & NP & NP & NP & NM \\
\hline \multicolumn{7}{|l|}{ CYCLE 7} \\
\hline Thickness & NP & $7.90 \mathrm{~m}$ & $5.30 \mathrm{~m}$ & $1.10 \mathrm{~m}$ & NP & \\
\hline Maximum clast size & NP & $4 \mathrm{~cm}$ & $1 \mathrm{~cm}$ & $0.03 \mathrm{~cm}$ & NP & \\
\hline Basal strata eroded into: & NP & shale & shale & shale & NP & \\
\hline Thickest bed & NP & $3.00 \mathrm{~m}$ & $1.50 \mathrm{~m}$ & $0.70 \mathrm{~m}$ & NP & \\
\hline Paleocurrent $\bar{m}$ and $\lambda$ & NP & $121^{\circ} ; 2$ & $158^{\circ} ; 3$ & $176^{\circ} ; 1$ & NP & $149^{\circ} \pm 29^{\circ} ; 6$ \\
\hline \multicolumn{7}{|l|}{ CYCLE 6} \\
\hline Thickness & NP & $5.10 \mathrm{~m}$ & $9.82 \mathrm{~m}$ & $5.90 \mathrm{~m}$ & $9.55 \mathrm{~m}$ & \\
\hline Maximum clast size & NP & $4 \mathrm{~cm}$ & $4 \mathrm{~cm}$ & $8 \mathrm{~cm}$ & $4.5 \mathrm{~cm}$ & \\
\hline Basal strata eroded into: & NP & shale & shale & shale & shale & \\
\hline Thickest bed & NP & $3.10 \mathrm{~m}$ & $1.80 \mathrm{~m}$ & $1.20 \mathrm{~m}$ & $2.60 \mathrm{~m}$ & \\
\hline Paleocurrent $\overline{\mathrm{m}}$ and $\lambda$ & NP & NM & $176^{\circ} ; 1$ & $158^{\circ} ; 2$ & $184^{\circ} ; 1$ & $169^{\circ} \pm 38^{\circ} ; 4$ \\
\hline \multicolumn{7}{|l|}{ CYCLE 5} \\
\hline Thickness & $2.40 \mathrm{~m}$ & $4.90 \mathrm{~m}$ & $4.15 \mathrm{~m}$ & $3.40 \mathrm{~m}$ & NP & \\
\hline Maximum clast size & $4 \mathrm{~cm}$ & $6 \mathrm{~cm}$ & $2.5 \mathrm{~cm}$ & $2 \mathrm{~cm}$ & NP & \\
\hline Basal strata eroded into: & shale & shale & shale & sandst & NP & \\
\hline Thickest bed & $1.60 \mathrm{~m}$ & $3.00 \mathrm{~m}$ & $0.90 \mathrm{~m}$ & $1.00 \mathrm{~m}$ & NP & \\
\hline Paleocurrent $m$ and $\lambda$ & $111^{\circ} ; 1$ & $173^{\circ} ; 1$ & $140^{\circ} ; 3$ & NM & NP & $141^{\circ} \pm 66^{\circ} ; 5$ \\
\hline \multicolumn{7}{|l|}{ CYCLE 4} \\
\hline Thickness & $8.55 \mathrm{~m}$ & $6.30 \mathrm{~m}$ & $4.70 \mathrm{~m}$ & $7.00 \mathrm{~m}$ & $4.30 \mathrm{~m}$ & \\
\hline Maximum clast size & $7 \mathrm{~cm}$ & $4.5 \mathrm{~cm}$ & $4 \mathrm{~cm}$ & $2.5 \mathrm{~cm}$ & $6 \mathrm{~cm}$ & \\
\hline Basal strata eroded into: & shale & shale & shale & shale & shale & \\
\hline Thickest bed & $1.45 \mathrm{~m}$ & $2.00 \mathrm{~m}$ & $0.90 \mathrm{~m}$ & $3.10 \mathrm{~m}$ & $1.20 \mathrm{~m}$ & \\
\hline Paleocurrent $m$ and $\lambda$ & $182^{\circ} ; 2$ & $97^{\circ} ; 1$ & $128^{\circ} ; 2$ & $168^{\circ} ; 2$ & $173^{\circ} ; 2$ & $155^{\circ} \pm 31^{\circ} ; 9$ \\
\hline \multicolumn{7}{|l|}{ CYCLE 3} \\
\hline Thickness & $12.45 \mathrm{~m}$ & $14.15 \mathrm{~m}$ & $18.60 \mathrm{~m}$ & 10.43 & $17.00 \mathrm{~m}$ & \\
\hline Maximum clast size & $4 \mathrm{~cm}$ & $3 \mathrm{~cm}$ & $3 \mathrm{~cm}$ & $6 \mathrm{~cm}$ & $7 \mathrm{~cm}$ & \\
\hline Basal strata eroded into: & shale & shale & shale & shale & shale & \\
\hline Thickest bed & $6.20 \mathrm{~m}$ & $4.70 \mathrm{~m}$ & $2.20 \mathrm{~m}$ & $3.90 \mathrm{~m}$ & $1.90 \mathrm{~m}$ & \\
\hline Paleocurrent $\mathrm{m}$ and $\lambda$ & $181^{\circ} ; 1$ & $183^{\circ} ; 4$ & $165^{\circ} ; 1$ & $146^{\circ} ; 4$ & $212^{\circ} ; 2$ & $174^{\circ} \pm 35^{\circ} ; 12$ \\
\hline \multicolumn{7}{|l|}{ CYCLE 2} \\
\hline Thickness & $10.60 \mathrm{~m}$ & $11.20 \mathrm{~m}$ & $18.17 \mathrm{~m}$ & $6.35 \mathrm{~m}$ & $7.55 \mathrm{~m}$ & \\
\hline Maximum clast size & $5 \mathrm{~cm}$ & $5 \mathrm{~cm}$ & $3 \mathrm{~cm}$ & $3 \mathrm{~cm}$ & $5 \mathrm{~cm}$ & \\
\hline Basal strata eroded into: & conglom. & shale & shale & shale & shale & \\
\hline Thickest bed & $2.00 \mathrm{~m}$ & $3.00 \mathrm{~m}$ & $2.70 \mathrm{~m}$ & $1.40 \mathrm{~m}$ & $1.70 \mathrm{~m}$ & \\
\hline Paleocurrent $\bar{m}$ and $\lambda$ & $189^{\circ} ; 6$ & $210^{\circ} ; 5$ & $204^{\circ} ; 5$ & $130^{\circ} ; 1$ & $266^{\circ} ; 3$ & $207^{\circ} \pm 43^{\circ} ; 20$ \\
\hline \multicolumn{7}{|l|}{ CYCLE 1} \\
\hline Thickness & $6.80 \mathrm{~m}$ & $10.45 \mathrm{~m}$ & $9.95 \mathrm{~m}$ & $7.55 \mathrm{~m}$ & NM & \\
\hline Maximum clast size & $4.5 \mathrm{~cm}$ & $3 \mathrm{~cm}$ & $4 \mathrm{~cm}$ & $3.5 \mathrm{~cm}$ & NM & \\
\hline Basal strata eroded into: & shale & shale & shale & shale & NM & \\
\hline Thickest bed & $4.70 \mathrm{~m}$ & $5.50 \mathrm{~m}$ & $1.50 \mathrm{~m}$ & $3.20 \mathrm{~m}$ & NM & \\
\hline Paleocurrent $\bar{m}$ and $\lambda$ & NM & NM & $\mathrm{NM}$ & $170^{\circ} ; 2$ & NM & $170^{\circ} \pm 8 ; 2$ \\
\hline CUMULATIVE VALUES; CYCLES & $1-8 *$ & & & & & \\
\hline Thickness & $93.70 \mathrm{~m}$ & $101.50 \mathrm{~m}$ & $106.41 \mathrm{~m}$ & 91. $\mathrm{F}^{-} \mathrm{m}$ & $98.28 \mathrm{~m}$ & \\
\hline Conglomerate + sandst: shale & 0.84 & 1.74 & 1.51 & 0.84 & $\cap .74$ & \\
\hline
\end{tabular}




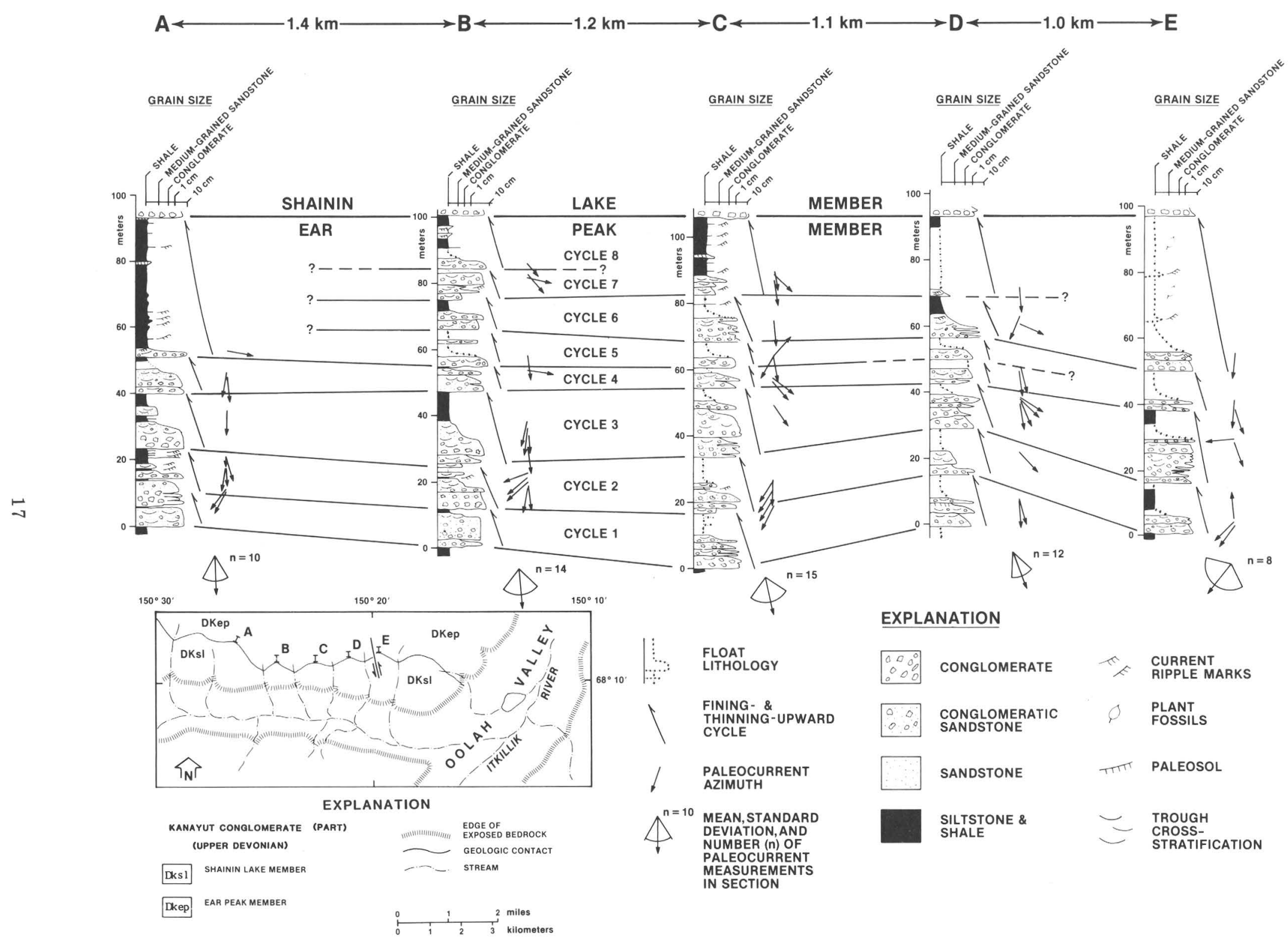

Figure 12.--Measured sections in the upper part of the Ear Peak Member of the Kanayut Conglomerate and index map (inset) west of the Itkillik River, Chandler Lake A-1 quadrangle. Geology modified from Brosge and others (1979). 


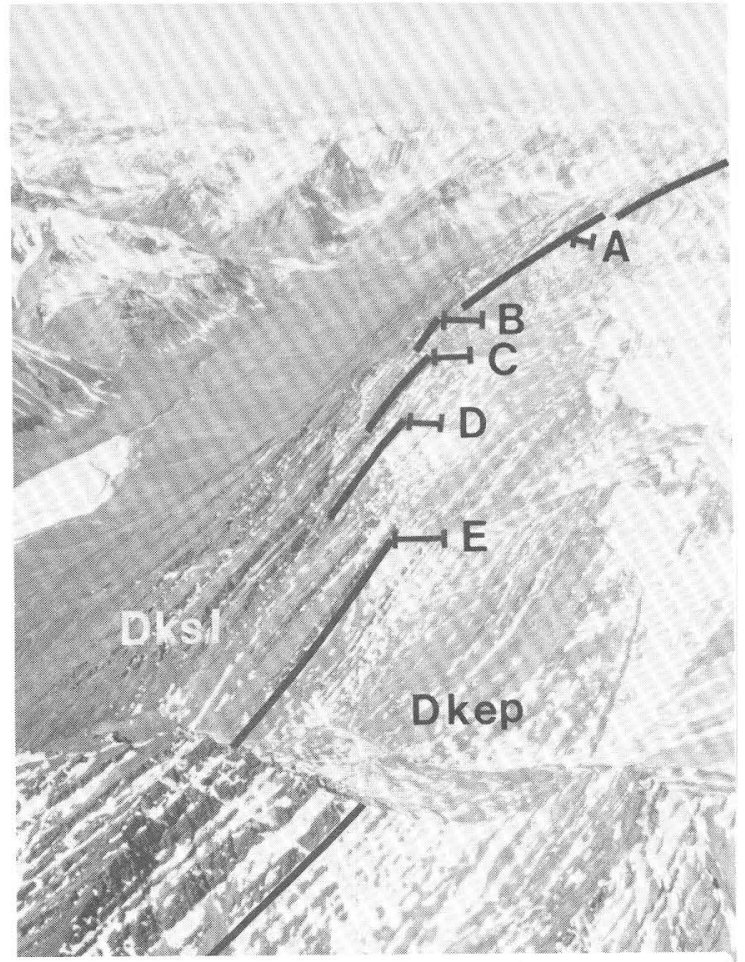

Figure 13.--Aerial view looking west of measured sections A, B, C, D, and E west of the Itkillik River. Abbreviations: Dkep, Ear Peak Member, Kanayut Conglomerate; Dksl, Shainin Lake Member, Kanayut Conglomerate.

is to examine lateral changes in individual thinningand fining-upward eycles of the Kanayut Conglomerate in an area where individual cycles can be traced laterally. Detailed sedimentologic variations are described herein from a thin stratigraphic interval of the upper part of the Ear Peak Member in a small area west of the Oolah Valley (Itkillik River) in the central Brooks Range, where the Ear Peak Member is about $1000 \mathrm{~m}$ thick (fig. 12, inset). Nilsen and others (1982) reported preliminary results of a similar study in this area but were able to measure only two sections because of inclement weather.

Five short sections (A through E) were measured during June 1984 on separate, south-trending spur ridges along a west-trending ridge in the Chandler Lake A-1 quadrangle (figs. 12, 13). The Ear Peak Member here strikes east-west and dips about $50^{\circ}$ southward; the sections extend for a strike distance of $4.5 \mathrm{~km}$. All sections were measured upward to the base of the Shainin Lake Member. Section E is displaced from section D by a small south-trending fault with approximately $40 \mathrm{~m}$ of left-lateral displacement.

Measured sections of the upper part of the Ear Peak Member can be divided into thinning- and fining-upward cycles characteristic of deposits of meandering streams. Bases of the cycles are channelized, and the lowest deposits consist of massive, imbricated, or trough-cross-stratified conglomerate and pebbly sandstone. In the overlying trough-cross-stratified sandstone, the grain sizes fine upward and the amplitudes of cross strata thin upward. The cross-stratified sandstone is typically overlain by current-rippled and laminated very fine grained sandstone and siltstone. These coarser grained lower parts of the cycles are interpreted to be the deposits of point bars on meander loops. Epsilon cross-stratification, representing paleo-point bar surfaces, is visible in several of the eycles.

Shale-rich deposits overlie the conglomerate and sandstone and form the upper part of each cycle. These deposits consists mainly of plantfossil-bearing brown, black, and maroon siltstone and shale that are interpreted to have been deposited on levees and floodplains between stream channels. Local coarsening-upward beds of siltstone and fine-grained sandstone, commonly capped by paleosols, may represent levee-top deposits; ungraded massive or cross-stratified sandstone beds are also locally intercalated with the shale and probably represent crevasse-splay deposits (Nilsen and Moore, 1982).

Eight thinning- and fining-upward cycles (1-8, fig. 12), can be reliably correlated by tracing both the basal contact of the Shainin Lake Member and several laterally continuous and prominent cycles within the measured interval. The lower four cycles can be traced for the 4.5-km-length of the study area, although cycle 2 has cut downward into the coarse-grained, channelized part of underlying cycle 1 in section A. Cycles 5 and 6 are present in sections $\mathrm{B}, \mathrm{C}$, and $\mathrm{D}$ but pinch out in sections $\mathrm{E}$ and $\mathrm{A}$, respectively. Cycle 7 is present in sections $B, C$, and $\mathrm{D}$; it thins and fines eastward. Cycle 8 is recognized only in section B and is less than $2.6 \mathrm{~km}$ in lateral extent.

Table 5 summarizes sedimentologic data from the point-bar deposits of the eight cycles. The point-bar-cycle thickness data indicate that the cycles are generally thinner in the upper part of the measured interval and lenticular in shape, although cycles 3,4 , and 6 appear to pinch and swell laterally. Because the thickness of point-bar sequences generally indicates paleostream depth, cycle thickness data indicate that although Ear Peak meandering streams were as deep as $18.6 \mathrm{~m}$, they were more commonly less than $10 \mathrm{~m}$ deep.

Maximum clast sizes in the eight cycles apparently vary nonsystematically along the outcrop length and are unrelated to either the thickness of the cycle or bedding (table 5). Except for cycle 2 in section $A$ and 5 in section $D$, each cycle is cut into the flood-plain deposits of the underlving cycle, indicating that the point-bar deposits are bounded above and below by floodplain shale.

Paleocurrent data indicate that sediment transport was mostly toward the south but appears to change systematically upward in the measured 
sections from southwest to southeast, as shown most clearly in section A (fig. 12). This vertical change is also shown by the paleocurrent summaries (table 5), in which the average paleocurrent directions are more southerly in cycles 1-3 and more southeasterly in cycles 4-8. Thicker cycles, generally more laterally continuous, have more southwesterly flow directions; the thinner cycles, generally less laterally continuous, have more southeasterly flow directions. However, the paleocurrent directions do not appear to vary systematically with maximum clast size or lateral position within a single cycle.

Because the Kanayut Conglomerate has an east-west strike in the study area, our stratigraphic cross-section is generally perpendicular to the southward direction of stream flow (fig. 12). Nevertheless, some cycles are laterally persistent for the total $4.5-\mathrm{km}$-strike length exposed in the study area. The less laterally continuous cycles may represent smaller tributary streams, whereas the continuous cycles may represent larger trunk streams.

On the basis of regional facies, paleocurrent, and clast-size data, Moore and Nilsen (1984, fig. 12) concluded that sediment was shed southwestward into the depositional basin of the Kanayut Conglomerate from principal points of distribution located $35 \mathrm{~km}$ east of the study area and north of Anaktuvuk Pass in the central Brooks Range and $400 \mathrm{~km}$ east of the study area and northeast of Arctic Village in the eastern Brooks Range. The measured sections presented herein, after palinspastic reconstruction, are located southeast of the Anaktuvuk Pass distribution point. We suggest that the upward change in sediment transport direction in the uppermost part of the Ear Peak Member in this area, from southwest-flowing trunk streams to southeastflowing tributary streams, may reflect the southwestward advance into the basin of the Anaktuvuk Pass depocenter. The depocenter may have formed a topographically elevated region with radial drainage on the larger Kanayut delta, thus causing reorientation of stream flow patterns around its margins.

\section{REFERENCES CITED}

Brosge, W. P., Reiser, H. N., Dutro, J. T., Jr., and Nilsen, T. H., 1979, Geologic map of Devonian rocks in parts of the Chandler Lake and Killik River quadrangles, Alaska: U.S. Geological Survey Open-File Map OF-79-1224, scale $1: 200,000$.

Moore, T. E., and Nilsen, T. H., 1984, Regional variations in the fluvial Upper Devonian and Lower Mississippian(?) Kanayut Conglomerate, Brooks Range, Alaska, in Nilsen, T. H., ed., Fluvial sedimentation and related tectonic framework, western North America: Special Issue of Sedimentary Geology, v. 38, p. 465497.
Nilsen, T. H., 1981, Upper Devonian and Lower Mississippian redbeds, Brooks Range, Alaska, in Miall, A. D., ed., Sedimentation and tectonics in alluvial Basins: Geological Association of Canada Special Paper No. 23, p. 187-220.

Nilsen, T. H., and Moore, T. E., 1982, Fluvial-facies model for the Upper Devonian and Lower Mississippian(?) Kanayut Conglomerate, Alaska, in Embry, A. F., and Balkwill, H. R., eds., Arctic geology and geophysics: Canadian Society of Petroleum Geologists Memoir No. 8, p. 1-12.

Nilsen, T. H., and Moore, T. E., 1984, Stratigraphic nomenclature for the Upper Devorian and Lower Mississippian(?) Kanayut Conglomerate, Brooks Range, Alaska: U.S. Geologicel Survey Bulletin 1529-A, p. A1-A64.

Nilsen, T. H., Moore, T. E., Balin, D. F., and Johnson, S. Y., 1982, Sedimentology and stratigraphy of the Kanayut Conglomerate, central Brooks Range, Alaska-Report of 1980 field season: U.S. Geological Surver OpenFile Report 82-199, 81 p.

Reviewers: W. P. Brosge and R. L. Detterman

\section{WEST-CENTRAL ALASKA}

(Figure 14 shows study areas described.)

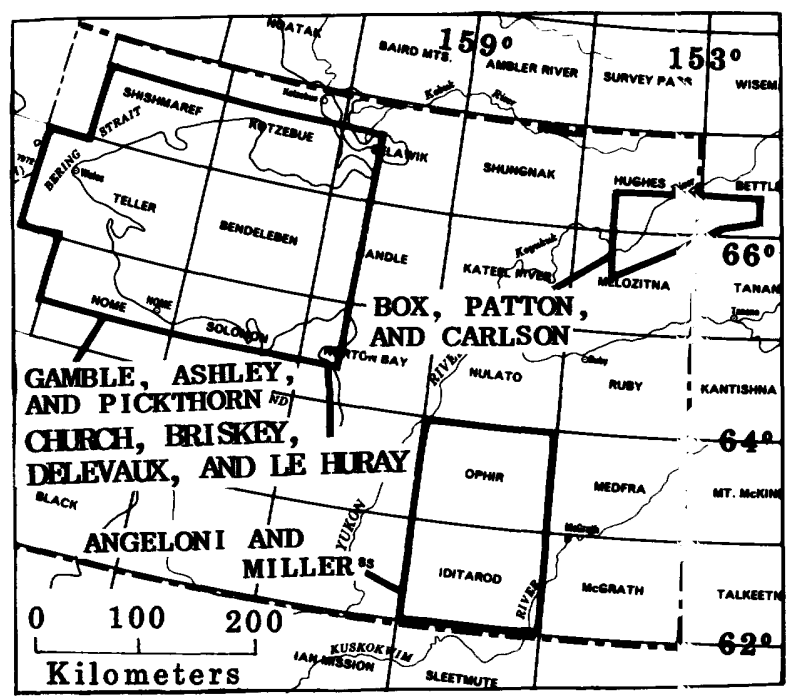

Figure 14.--Map showing areas in west-central Alaska discussed in this circular.

\section{GREENSCHIST FACIES METAMORPHIC FOCKS OF NORTH-CENTRAL IDITAROD QUADRANGLE}

\section{Linda M. Angeloni and Marti L. Mille*}

Greenschist-facies metamorphic rocks were mapped in the north-central part of the Iditarod quadrangle in 1984. They are best exposed on the. 
ridge that extends from VABM Ideal to VABM Lonesome, along a northeast-striking structural trend (fig. 15). Outcrops consist of weakly to strongly foliated mafic schist and subordinate, well-foliated pelitic schist. These rocks appear correlative with Precambrian and Paleozoic greenschist facies rocks in the Ophir quadrangle reported by Chapman and others (1985). However, they differ from other probable Precambrian and Paleozoic metamorphic rocks found to the southwest near VABM Idono.

Petrographic study of eleven samples indicates a range in metamorphic grade from lower greenschist- to upper greenschist-facies. The upper greenschist-facies rocks are characterized by the assemblage of actinolitic hornblende $(50 \%)+$ quartz $(30 \%)+$ epidote $(15 \%)+$ chlorite $(2 \%)+$ sphene $(2 \%)$ + hematite $(<1 \%)$. Middle greenschist-facies rocks are represented by a suite of assemblages:

actinolite $(45 \%)+$ +epidote $(35 \%)+$ quartz $(10 \%)+$ chlorite $(5 \%)+$ sphene $(3 \%)+$ hematite $(<1 \%)$;

quartz $(50 \%)+$ epidote $(20 \%)+$ actinolite $(20 \%)+$ biotite $(9 \%)+$ chlorite $(1 \%)+$ hematite $(<1 \%)$; and

actinolite $(30 \%)+$ plagioclase $(25 \%)+$ epidote $(20 \%)+$ sphene $(20 \%)+$ chlorite $(4 \%)+$ muscovite $(1 \%)$.

Lower greenschist facies rocks have an assemblage of:

quartz $(90 \%)+$ carbonaceous material $(5 \%)+$ muscovite $(2.5 \%)+$ chlorite $(2.5 \%)$.

Textures of these eleven samples are strongly related to their respective metamorphic grade. Highest grade rocks are completely recrystallized to a schistose fabric and are considered to be metabasite. Middle greenschist-facies rocks have relict porphyritic and granoblastic textures, which represent metabasalt and possibly metatuff. Lowest grade rocks are pelitic sediments with crenulated and foliated textures.

In the adjacent Ophir quadrangle, Chapman and others (1985) mapped a unit containing largely Precambrian and Paleozoic greenschist-facies metamorphic rocks composed in part of mafic schist and quartz-mica schist. They occur in the southeast quadrant of the Ophir quadrangle near VABM Dish and VABM Esperanto following a northeasterly regional trend. These rocks are in contact with a unit of chert, argillite, and volcaniclastic rocks from which Mississippian and Triassic Radiolaria have been recovered. The chert is characterized by pervasive fractures, shears, and recrystallized Radiolaria (Chapman and others, 1985). Similar (but undated) chert is found in the Iditarod quadrangle where it is spatially associated with the mafic and pelitic schist of the Ideal-Lonesome trend. This association suggests that the units reported in the southeast Ophir quadrangle extend into the Iditarod quadrangle.

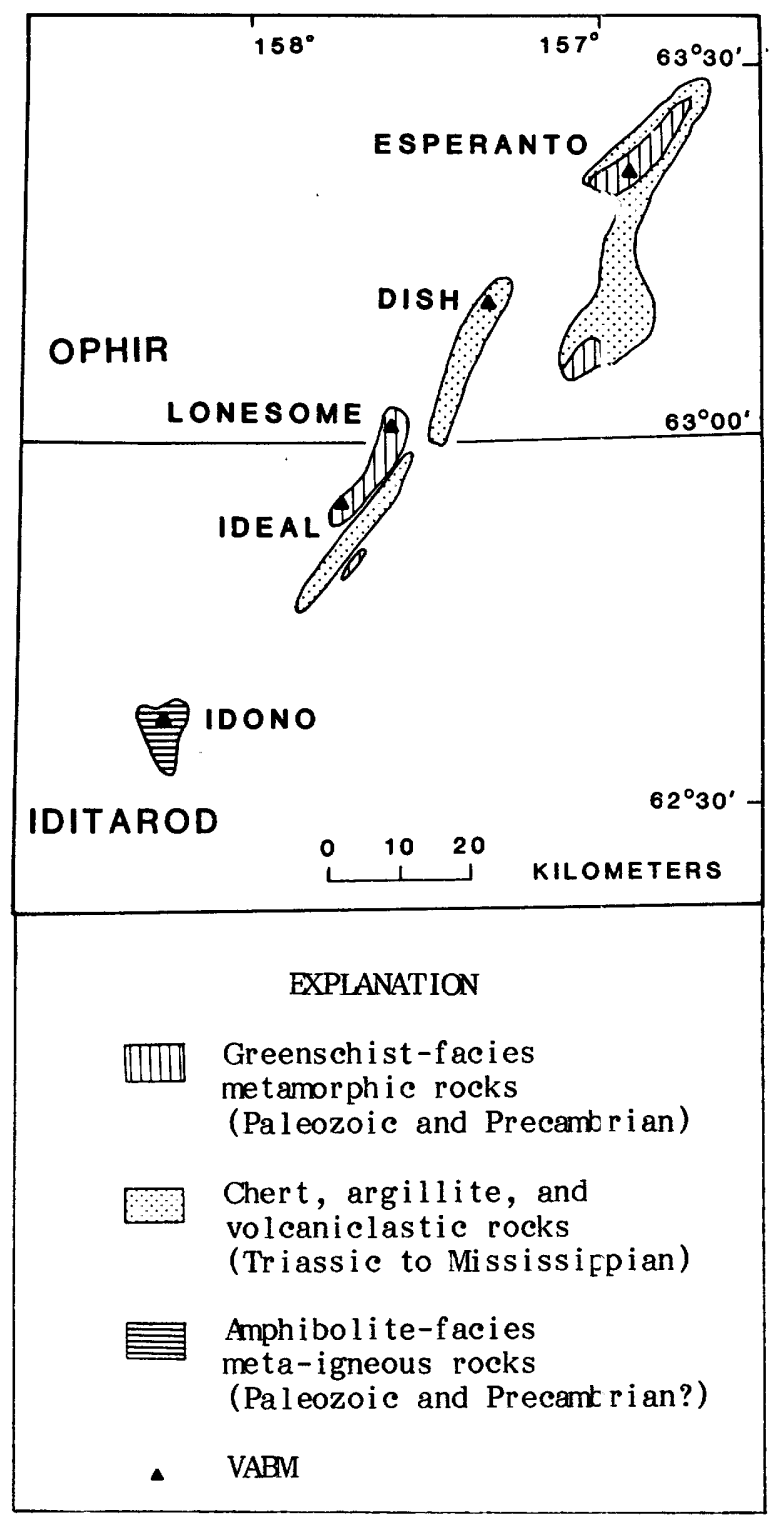

Figure 15.--Schematic geologic map of the central Ophir and Iditarod quadrangles.

Occurring along the same structural trend, metamorphic rocks that crop out to th? southwest near VABM Idono differ markedly in composition, grade, and texture to those at VABMI Ideal and VABM Lonesome. The Idono sequence consists of amphibolite-grade augen gneiss, amphibolite, and pelitic schist (Miller and Bundtzen, 1985). In addition, foliated granodiorite crops out in rroximity to the Idono sequence. Higher metamorphic grade, presence of foliated igneous rocks, and absence of greenschist-facies metamafic rocks in the Idono sequence distinguish these rocks from those of the Ideal-Lonesome trend. 


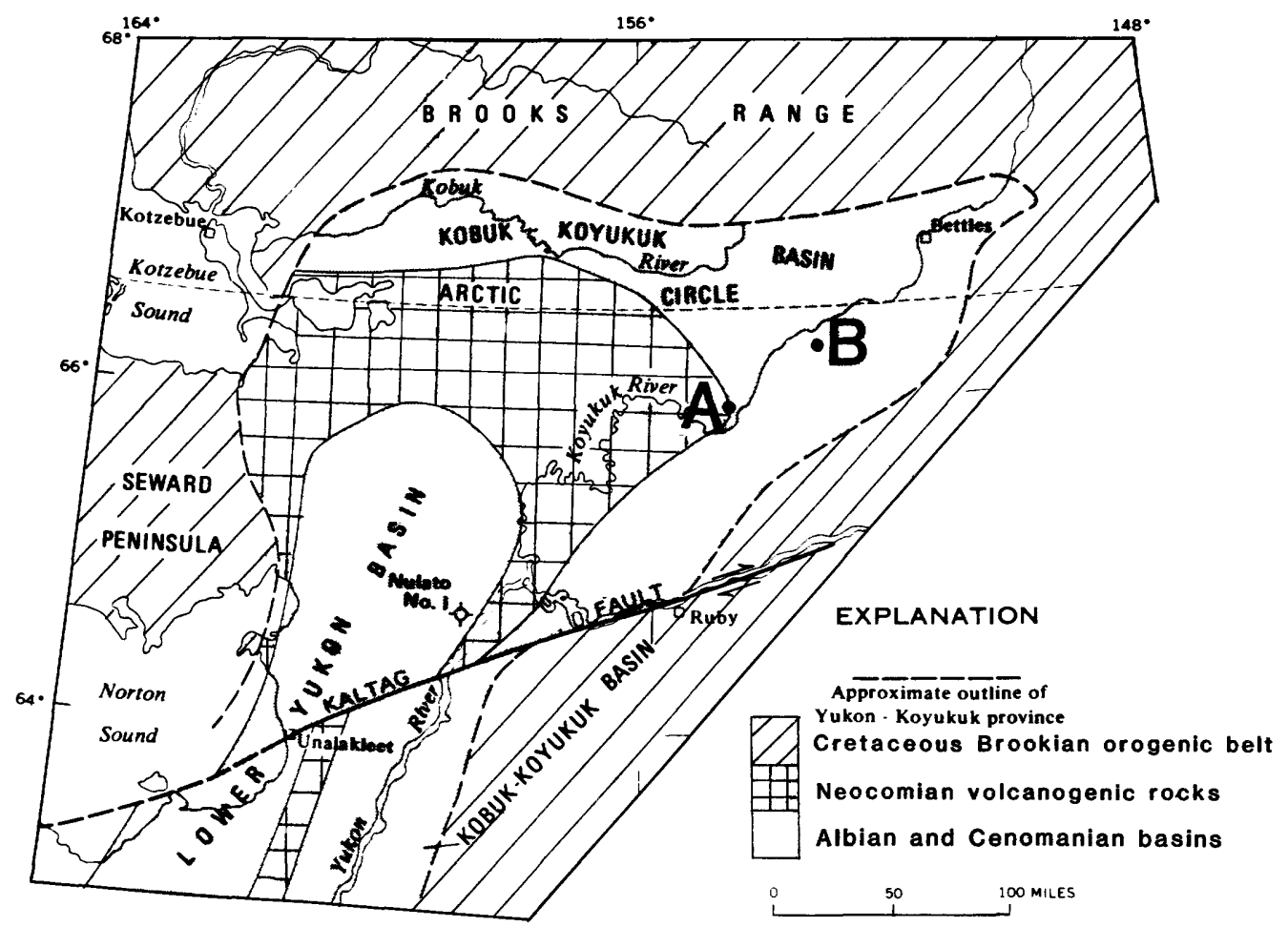

Figure 16.--Generalized map of Lower and middle Cretaceous rocks of the Yukon-Koyukuk basin (with locations of stratigraphic sections A and B shown in fig. 17); concurrent uplift of the schistose Brookian orogenic belt is suggested by predominance of Early Cretaceous $\mathrm{K}$-Ar cooling ages from metamorphic rocks.

The greenschist-facies rocks of the IdealLonesome trend appear to belong to the Ruby terrane (Jones and others, 1984), a widespread, structurally complex assemblage of metasedimentary and metamorphic rocks that extends northeastward across central Alaska and comprises the core of the Ruby geanticline. Higher grade rocks of the Idono sequence may represent a local variant within the Ruby terrane, but present field and petrographic data suggest that these rocks are distinet. At this time, the possibility that the Idono sequence has a different tectonic history than the Ideal-Lonesome trend cannot be ruled out.

\section{REFERENCES CITED}

Chapman, R. M., Patton, W. W., Jr., and Moll, E. J., 1985, Reconnaissance geologic map of the Ophir quadrangle, Alaska: U.S. Geological Survey Open-File Report 85-203.

Jones, D. L., Silberling, N. J., Coney, P. J., and Plafker, George, 1984, Lithotectonic terrane map of Alaska (west of the 141st Meridian) Part A, in Silberling, N. J., and Jones, D. L., eds., Lithotectonic terrane maps of the North American Cordillera: U.S. Geological Survey Open-File Report $84-523,4$ pl., scale $1: 2,500,000$.
Miller, M. L., and Bundtzen, T. K., 1985 Metamorphic rocks in the western Iditarod quadrangle, west-central Alaska, in Bartsch-Winkler, Susan, and Reed, K. M., eds., U.S. Geslogical Survey in Alaska-Accomplishments during 1983: U.S. Geological Survey Circulrr 945, p. 24-28.

Reviewers: J. H. Dover and W. W. Patton, Jr.

\section{EARLY CRETACEOUS EVOLUTION OF THE NORTHEASTERN YUKON-KOYUKUK BASIN, WEST-CENTRAL ALASKA}

\section{Stephen E. Box, William W. Patton, Jr., and Christine Carlson}

The Brookian orogenic belt (fig. 16) ras previously been interpreted to be the result of an arccontinent collision in the Early Cretaceous (Roeder and Mull, 1978; Gealey, 1980; Box, 1985). The adjacent Yukon-Koyukuk basin is partly underlain by the colliding volcanic arc terrane (Koyukuk terrane of Jones and others, 1984). This report, which focuses on the voleanic and sedimentologic evolution of part of the northeastern Yukon-Koyukuk basin, documents the response of the volcanic arc termane to the collision. 


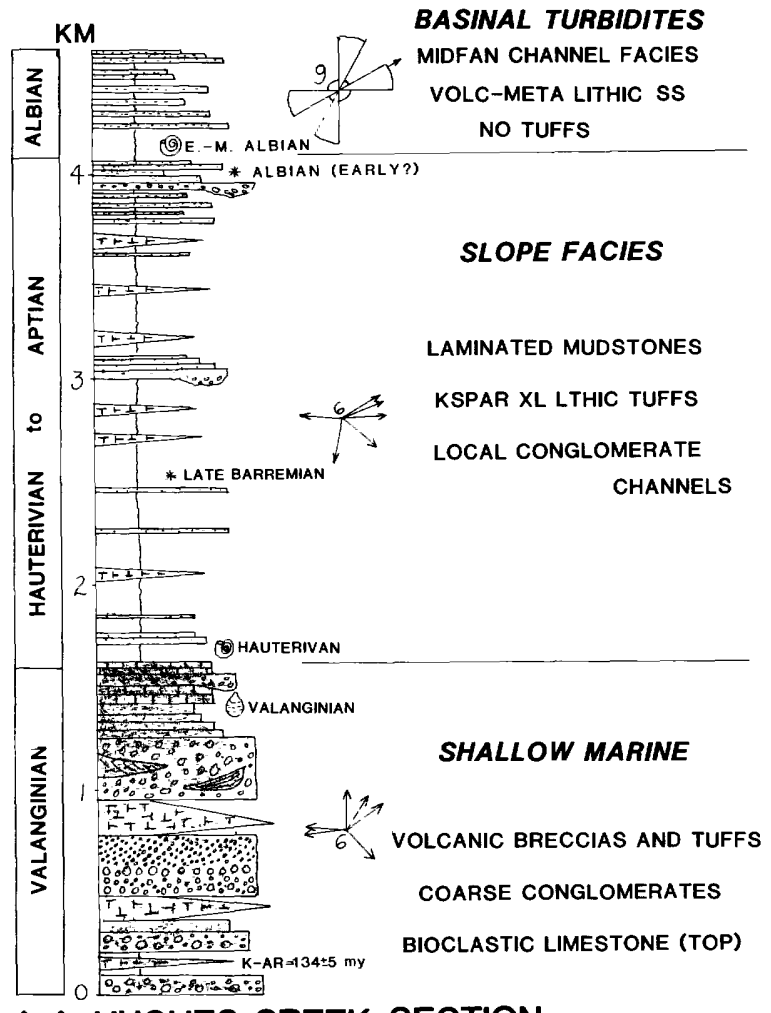

(A) HUGHES CREEK SECTION

(Hughes A-3 quadrangle: T8-9N, R2 1E)

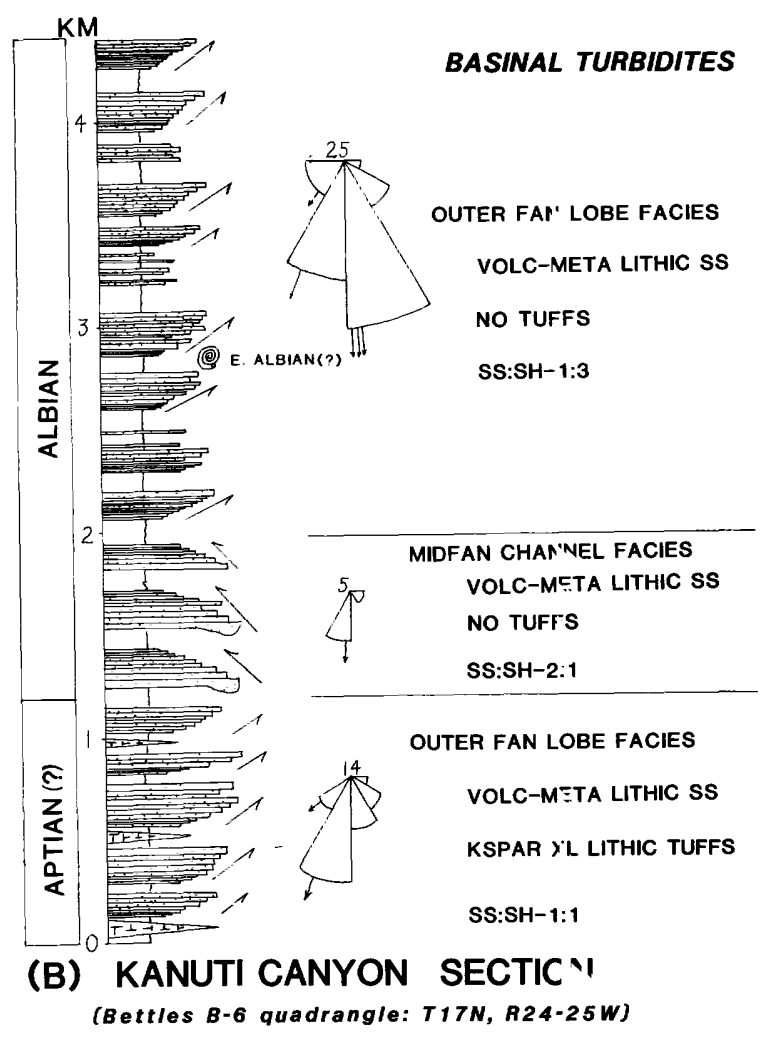

EXPLANATION

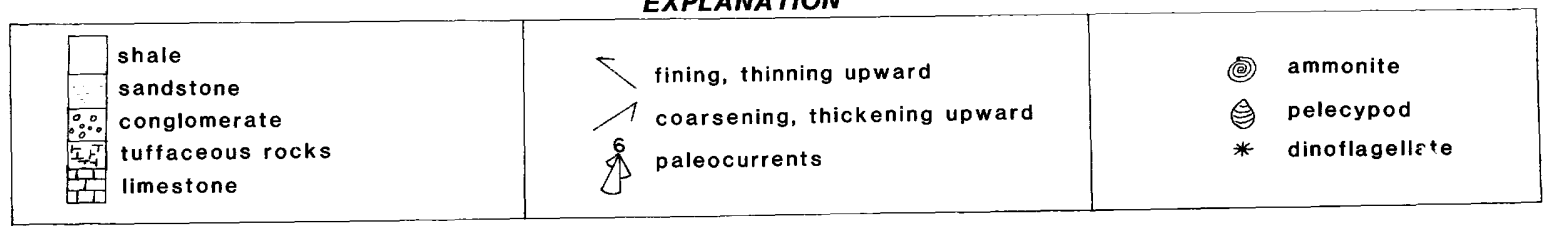

Figure 17.--Generalized stratigraphic sections from northeastern Yukon-Koyukuk basin: correlation between sections is based on abrupt upward disappearance of distinctive potassium feldspar-rich tuff beds in each section.

Patton (1973) previously divided the Lower Cretaceous rocks of the basin into two broad stratigraphic sequences: a lower sequence of Neocomian volcanic and volcaniclastic rocks and an upper sequence of Albian and younger polymictic clastic rocks. For this report,two stratigraphic sections (see fig. 16) were studied in order to investigate both the nature of these strata and the stratigraphic transition between these two sequences. New data on their biostratigraphy, sedimentology, sedimentary petrography, and volcanic geochemistry are reported here in preliminary form.

The Hughes Creek section (fig. 17A) exposes the transition between the two sequences. The lowest exposed unit is Valanginian in age (Patton, 1973) and consists of volcanic and volcaniclastic rocks deposited in predominantly shallow-marine environments. Volcanic rocks are vesicular plagioclase + cli- nopyroxenethornblende porphyries that ranre from basalt to dacite in composition. New trace-element data from several samples of Neocomian volcanic rocks, when plotted on discriminant diagrams (fig. 18) of Pearce and Cann (1973), suggest a subduction-related volcanic arc origin. Interbedded clastic rocks are entirely volcanolithic and are $\mathrm{bo}^{+} \mathrm{h}$ pyroclastic and epiclastic in origin. Lenticular cobble conglomerates, large-scale $(1 \mathrm{~m})$ cross-bedding, and relatively common fossiliferous horizons indicate shallow-marine deposition. A sandy coquinoid limestone is located at or near the top of the Valanginian section.

Lying conformably above the Valangirian unit is a middle unit, $2,500 \mathrm{~m}$ thick, of thin-bedded shaley strata. Hauterivian ammonites were identified from near the base of the unit (J. W. Miller, USGS, written commun., 1984), and Barremian and early(?) 
Albian dinoflagellates were recovered from calcareous concretions in the middle and near the top of the unit, respectively (N. R. D. Albert, USGS, written communs., 1984, 1985). This unit consists of laminated dark shale with thin interbedded volcaniclastic siltstone and fine sandstone and rare matrix- and framework-supported conglomerates. Partially welded ash-flow tuff beds as thick as $1.3 \mathrm{~m}$ are sporadically interbedded through the Barremian part of the section. These tuffs contain abundant potassium feldspar in the form of both phenocrysts and groundmass, as well as rare biotite phenocrysts, but lack phenocrystic quartz. Interbedded sandstone (also lacking metamorphic detritus) is composed of similar potassium feldspar-rich volcanic fragments. These sedimentary rocks commonly contain incomplete Bouma sequences $\left(\mathrm{T}_{\text {cde }}\right)$ with thick Tc intervals, suggestive of deposition below the wave base. The generally fine grain size, minor slump fold horizons, rare interbedded conglomeratic horizons, and the stratigraphic position between shallow-marine and turbidite basin deposits suggest this unit represents deposition in a sediment-bypassed slope environment (Mutti and Ricci Lucchi, 1972).

The upper unit, which conformably overlies the middle unit, contains fragmentary early to middle Albian ammonites (J. W. Miller, USGS, written commun., 1984) near its base along Hughes Creek. Compositionally, these sandstones were derived from a mixed igneous and low-grade metamorphic source, similar to that presently exposed in the southern Brooks Range. Basal strata are fissile, hemipelagic shales (basin plain?), which are overlain by massive amalgamated sandstone intervals (facies B and C; Mutti and Ricci Lucchi, 1972), indicative of a mid-fan (channel?) environment. Sole markings indicate south- to southeast-directed paleocurrents, supporting a Brooks Range source.

The Kanuti Canyon section (fig. 17B), located $75 \mathrm{~km}$ northeast of the Hughes Creek section, consists entirely of turbidites with a total thickness of over $4 \mathrm{~km}$. The age is poorly constrained by a fragmentary ammonite of probable early Albian age (D. L. Jones, USGS, written commun., 1971) about $1 \mathrm{~km}$ below the top of the section. Sandstone petrography and south-directed paleocurrents suggest a Brooks Range source for these turbidites. Interbedded with the polymictic turbidites in the lower kilometer of section are thick (1-2 m) tuffaceous turbidites lithologically identical to the tuffs from the middle unit of the Hughes Creek section. Most of the Kanuti Canyon section correlates with the upper unit of the Hughes Creek section; the lower kilometer is tentatively correlated with the middle unit (Hauterivian to early(?) Albian) of the Hughes Creek section.

In summary, the Early Cretaceous history of the northeastern Yukon-Koyukuk basin is interpreted to record the collisional demise of a subductionrelated volcanic arc (Box, 1985). Valanginian arc volcanism occurred within a shallow-marine vol-
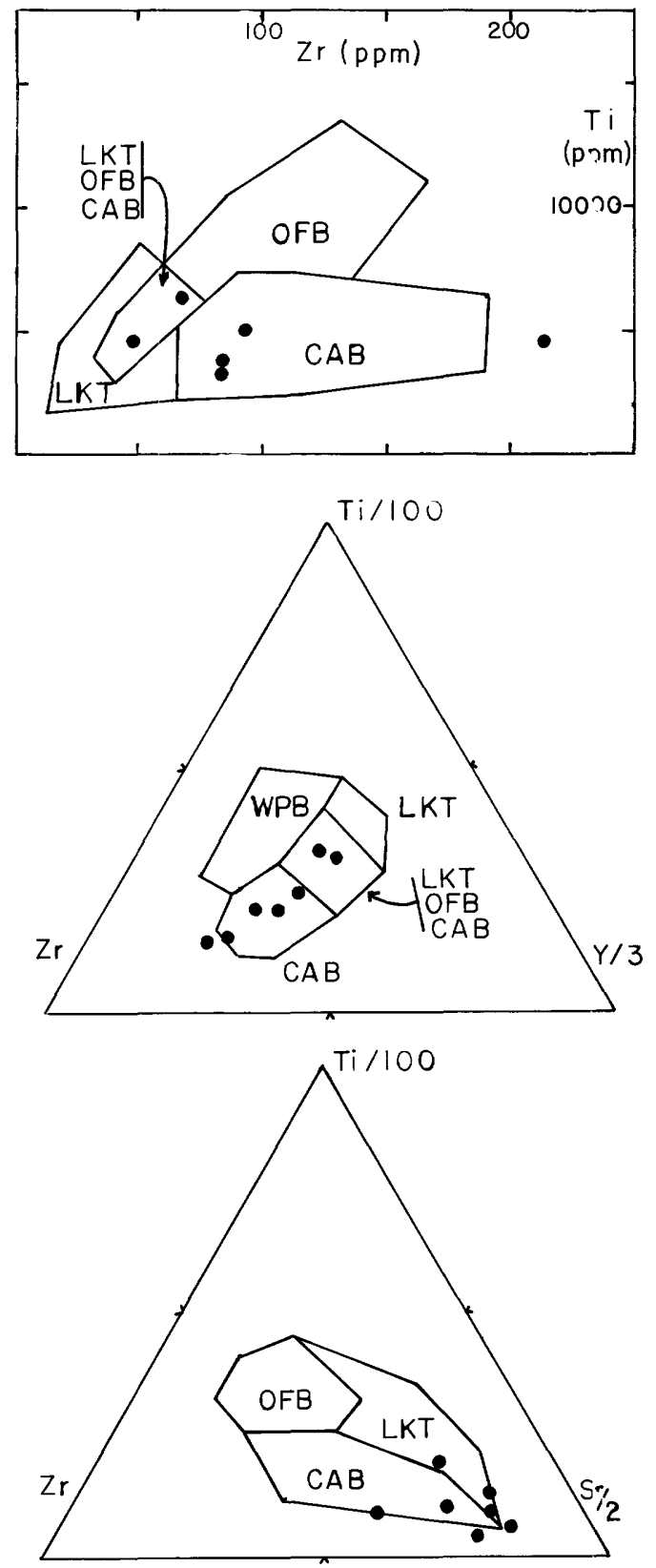

Figure 18.--Trace element data from Neccomian basalts $\left(\mathrm{SiO}_{2}<53 \% ; \mathrm{CaO}+\mathrm{MgO}=11-20 \%\right)$ from Hughes Creek area, plotted on three discriminant diagrams of Pearce and Cann (1973). LKT $=$ low-K tholeiites; $\mathrm{CAB}=$ calc-alkaline basalt; $\mathrm{OFB}=$ oceanfloor basalts; $W P B=$ within-plate basalts.

caniclastic platform. In Hauterivian time, volcanism changed to a more highly potassic type, concurrent with marked subsidence of the shallow-marine platform. Orogenic sediments from the Brooks Range reached the inferred off-platform farts of the basin in pre-Albian time and interfinger?d with 
these potassic tuffs. Orogenic sediments gradually onlapped the volcanic high itself, reaching the Hughes area by early or middle Albian time.

The sedimentologic and volcanic response of the Koyukuk (volcanic arc) terrane to collision is similar to that recorded in more recent arc-continent collisions. Chi and others (1981) document a similar evolution of arc subsidence and progressive onlap by orogenic sediments during Neogene arc-continent collision in eastern Taiwan. A change to highly potassic, shoshonitic volcanism concurrent with arccontinent collision has been documented in the western Philippines (Wolfe and Self, 1983), the eastern Sunda arc (Foden and Varne, 1980), the Aeolian arc (Barberi and others, 1974), and elsewhere (Morrison, 1980).

\section{REFERENCES CITED}

Ba:beri, Franco, Innocenti, Fabrizio, Ferrara, Giorgio, Keller, Jorg and Villari, Letterio, 1974, Evolution of Aeolian arc volcanism: Earth and Planetary Science Letters, v. 21, p. 269-276.

Box, S. E., 1985, Early Cretaceous orogenic belt in northwestern Alaska: internal organization, lateral extent and tectonic interpretation, in Howell, D. G., ed., Tectonostratigraphic terranes of the Circum-Pacific region: Earth Science Series, v. 1, Circum-Pacific Council for Energy and Mineral Resources (in press).

Chi, W. R., Namson, Joy, and Suppe, John, 1981, Stratigraphic record of plate interactions in the Coastal Range of eastern Taiwan: Geological Society of China Memoir, no. 4, p. 155194.

Foden, J. D., and Varne, Richard, 1980, The petrology and tectonic setting of QuaternaryRecent volcanic centres of Lombok and Sumbawa, Sunda Arc: Chemical Geology, v. 30, no. 3, p. 201-226.

Gealey, W. K., 1980, Ophiolite obduction mechanism, in Panayiotou, A., ed., Ophiolites: Cyprus Geological Survey Department, Nicosia, Cyprus, p. 228-243.

Jones, D. L., Silberling, N. J., Coney, P. J., and Plafker, George, 1984, Lithotectonic terrane map of Alaska (west of 141st meridian), in Silberling, N. J., and Jones, D. L., eds., Lithotectonic terrane maps of the North American Cordillera: U.S. Geological Survey Open-File Report 84-523, scale 1:5,000,000.

Morrison, G. W., 1980, Characteristics and tectonic association of the shoshonite rock association: Lithos, v. 13, p. 97-108.

Mutti, Emiliano, and Ricci Lucchi, Franco, 1972, Turbidites of the northern Apennines: introduction to facies analysis: Memorie della Societa Geologica Italiana, v. 11, p. 161-199 (English translation by Tor Nilsen, International Geology Review, 1978, v. 20, no. 2, p. 125-166).
Patton, W. W., Jr., 1973, Reconnaissance geology of the northern Yukon-Koyukuk province, Alaska: U.S. Geological Survey Professional Paper 774-A, p. A1-A17.

Pearce, J. A., and Cann, J. R., 1973, Tectonic setting of basic volcanic rocks determined using trace element analyses: Earth and Planetary Science Letters, v. 19, p. 290-30n.

Roeder, Dietrich, and Mull, C. G., 1978, Tectonics of the Brooks Range ophiolites, Alaska: American Association of Petroleum Geologists Bulletin, v. 62 , p. $1696-1713$.

Wolfe, J. A., and Self, Stephen, 1983, Structural lineaments and Neogene volcanism in southwestern Luzon, in Hayes, D. E., ed., The tectonic and geologic evolution of southeast Asian seas and island: American Geophysical Union Geophysical Monograph 27, pt. 2, p. 157-172.

Reviewers: T. H. Nilsen and T. L. Vallier

\section{PRELIMINARY RESULTS OF PB-ISOTOPE ANALYSES OF DETOSITS FROM THE SEWARD PENINSULA}

\section{Stanley E. Church, Joseph A. Briskey, Maryse H. Delevaux, and Anne P. LeHuray}

Lead-isotopic compositions have been determined from galena samples from five different sulfide deposits sampled during a re?onnaissance study of the Soloman and Bendeleben quadrangles. Samples were collected from the Lost River Mine, Independence Mine, Pargon and Niukluk Rivers area, the Foster prospect, the Hannum Creek prospect and the Wheeler prospects as a part of the geological and mineral assessment of these quadrangles during the Alaska Mineral Resource Assessment Program (AMRAP)(Till, 1983). Sample localities are shown on figure 19 and the $\mathrm{Pb}$-isotopic results on figure 20 .

$\mathrm{Be}-\mathrm{Sn}-\mathrm{W}-\mathrm{As}-\mathrm{Pb}$ fissure-vein deposits in the Lost River Mine area in the Teller quadrangle are associated with the Lost River pluton (Sainsbury, $1964,1969)$ of Late Cretaceous age $(80.2+2.9$ m.y.; Hudson and Arth, 1983). This pluton is one of several associated with tin mineralization ertending ENE across the Seward Peninsula. Pb-isotop? analyses of several galena samples from fissure veins in the mine area plot within the limits of anslytical error (fig. 20).

Independence $\mathrm{Mine}$ is a $\mathrm{Zn}-\mathrm{Pb}-\mathrm{Ag}-\mathrm{Au}$ deposit containing massive and disseminated, partially oxidized, sphalerite, galena and tetral odrite with quartz and calcite. It is localized in a north-trending, steeply dipping, shear zone in pre-Devonian schistose marbles here considered part of the Nome Group (Till, 1983) within $4 \mathrm{~km}$ of the nargin of the Kugruk pluton, a quartz monzonite pluton also of Late Cretaceous age (95 m.y.; T. P. Miller, USGS, oral commun., 1985). The difference between the 


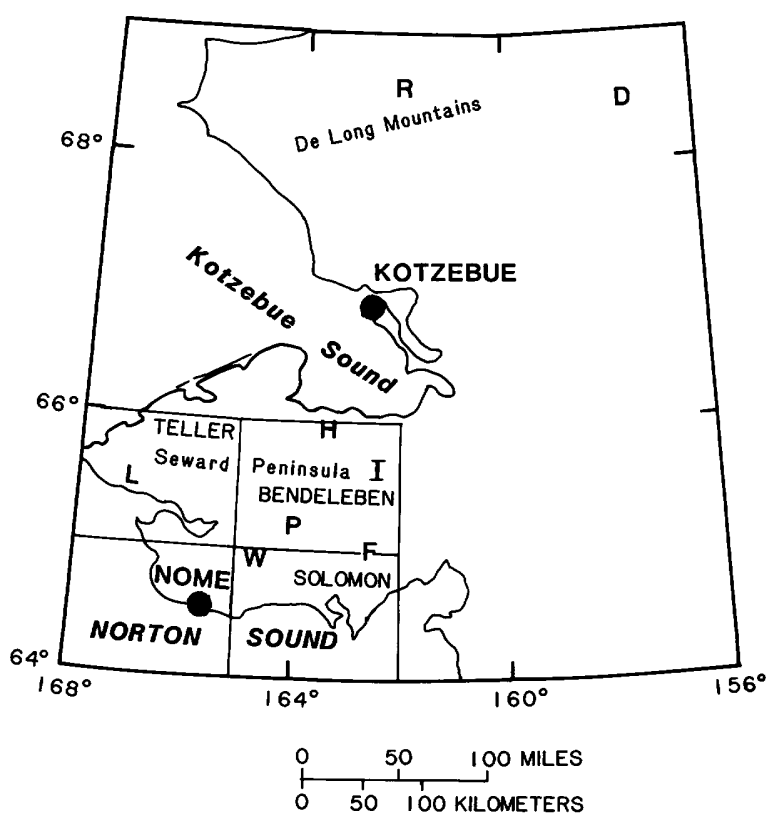

Figure 19.--Localities of samples discussed in this study: R, Red Dog; D, Drenchwater Creek; H, Hannum Creek; L, Lost River Mine; W, Wheeler; I, Independence Mine; P, Pargon; and F, Foster.

$\mathrm{Pb}$-isotopic results from these two fissure veins is consistent with the $15 \mathrm{~m} . \mathrm{y}$. age difference for the deposits. The $\mathrm{Pb}$-isotopic data from these deposits define the ${ }^{238} \mathrm{U} /{ }^{204} \mathrm{~Pb}$ and ${ }^{232} \mathrm{Th} /{ }^{238} \mathrm{U}$ present in the source region, and establish the growth curve for the evolution of $\mathrm{Pb}$ associated with magmatic processes on the Seward Peninsula. Note that the magmatic growth curve for $\mathrm{Pb}$ on the Seward Peninsula differs from either of the two reference growth curves shown in figure 20 .

A deposit containing galena, chalcopyrite, and pyrite(?) was sampled from a prospect in the western Bendeleben Mountains between the Pargon and Niukluk Rivers. Mineralization occurs in fracture zones that cross-cut garnet- and tourmaline-bearing dikes as well as amphibolite schist country rock. The deposit is spatially associated with small rhyolitic to monzonitic intrusive bodies just north of the Cretaceous Pargon pluton, which are the probable cause of complex geochemical anomalies found by Bundtzen (1974) and King (1984). Pb-isotopic data from these occurrences are similar to those from the Independence Mine and probably represent magmatic hydrothermal activity of Cretaceous age.

The Foster prospect, located in the Omilak Mountain area of the western Darby Mountains, consists of galena-bearing gossans in marble (probably of the Nome Group) that are localized along a series of veins in the crest of an anticlinal fold. Mulligan (1962) reports high $\mathrm{Pb} / \mathrm{Zn}$ ratios (7.6) with an average of 3.73 percent $\mathrm{Pb}$ recovered from drilling and anomalous concentrations of $\mathrm{Ag}, \mathrm{As}, \mathrm{Au}$,

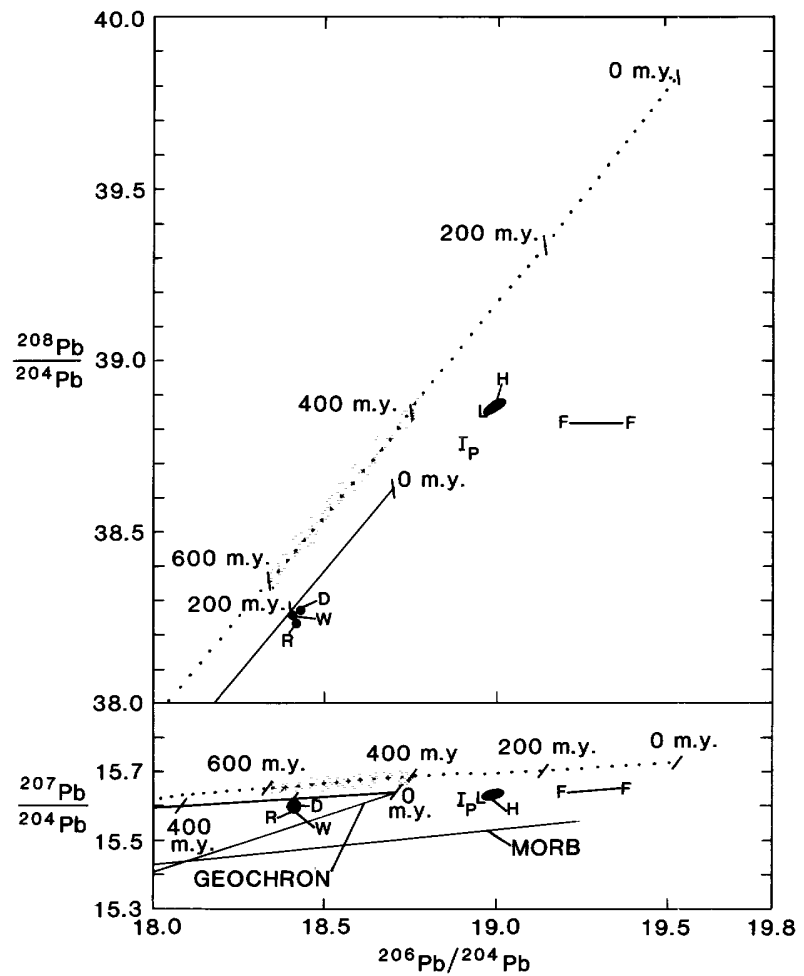

Figure 20.-- $\mathrm{Pb}$ isotope diagram showing the relationship of various deposits. See figur? 19 for symbol designations. The SEDEX growtr curve, derived from the deposits of the Selwyn Basin (Godwin and Sinclair, 1982), the growth curve of Stacey and Kramers (1975), and the mid-ocean ridge line (MORB) are shown for reference. The range of $\mathrm{Pb}$-isotopic data from SEDEX-type deposits from the Selwyn Basin (Godwin and Sinclair, 1982) are shown by the stippled pattern.

$\mathrm{Cu}, \mathrm{Mn}$, and $\mathrm{Sn}$. Middle Cretaceous granit c rocks occur in the Windy Creek pluton [(middle Cretaceous?); T.P. Miller, USGS, oral commun., 1985] about $15 \mathrm{~km}$ to the north; the Dry Canyon Creek stock (108 m.y.; Miller, 1972) to the south; and the Darby pluton (88-94 m.y., Miller and Bunker, 1976) to the east of Omilak Mountain. Mineralization extends north of Omilak Mountain to within one kilometer of the contact of the Windy Creek stcrk.

Isotopic analysis of galena samples from the Foster prospect resulted in a radiogenic $\mathrm{Pb}$-isotopic composition that differs significantly from the ores associated with Cretaceous magmatic activity (see figure 20). $\mathrm{Pb}$-isotopic data from galena samples at the Foster prospect lie along the same ${ }^{238} \mathrm{U} /{ }^{204} \mathrm{~Pb}$ growth curve as the Pargon, Independence, and Lost River samples. However, there is a pronounced shift in the plot of ${ }^{208} \mathrm{~Pb} /{ }^{204} \mathrm{~Pb}-{ }^{206} \mathrm{~Pb}-{ }^{20} \mathrm{~Pb}$ data from the Foster prospect (upper part of fig. 20). This feature of $\mathrm{Pb}$-isotope behavior indicates a different $\mathrm{Th} / \mathrm{U}$ ratio in the source region where radio- 
genic decay occurred. Several alternative explanations for the presence of radiogenic $\mathrm{Pb}$ at the Foster prospect are possible, but the most plausible explanation is that $\mathrm{Pb}$ from these deposits results from leaching of lead from the metamorphic host rocks. In such cases, ores commonly are uranogenic (Doe, 1970); that is, the $\mathrm{Pb}$-isotopic signature of the ore contains an abnormally high amount of ${ }^{206} \mathrm{~Pb}$ due to decay of uranium caused by a decoupling of the uranium and thorium systems during metamorphism.

The Hannum Creek prospect occurs in marble and quartzite interlayered with carbonaceous quartz schist of the Nome Group (J. A. Briskey, A. B. Till, and B. M. Gamble, USGS, written commun., 1985). The deposit consists of stratif form accumulations of partially oxidized, disseminated to massive pyrite, sphalerite, and galena, principally in laminae of quartzite interlayered with manganiferous calcitic, dolomitic, and ankeritic marbles. The deposit has many attributes of sediment-hosted submarine exhalative $\mathrm{Zn}-\mathrm{Pb}$ (SEDEX) deposits (J. A. Briskey, A. B. Till, and B. M. Gamble, USGS, written commun., 1985).

Two galena samples were analyzed from Hannum Creek prospect. Isotopic results are similar to those from the Pargon River, Independence, and Lost River areas; on the basis of the $\mathrm{Pb}$-isotopic data alone, one might expect that Hannum Creek was a Cretaceous magmatic-hydrothermal deposit. The $\mathrm{Pb}$-isotopic data from Hannum Creek are radiogenic for SEDEX-type deposits. For example, SEDEX-type deposits of the Selwyn Basin in the Canadian Cordillera (Godwin and Sinclair, 1982) plot on a higher growth curve and reflect the 1.89 b.y. Hudsonian basement of the Canadian shield (see fig. 20 ), yet contain less ${ }^{206} \mathrm{~Pb}$. However, some $\mathrm{Pb}$ samples from SEDEX-type deposits in Devonian and Mississippian rocks in the McMillian Pass and Akie River areas of the Canadian Cordillera (Godwin and Sinclair, 1982) contain nearly as much ${ }^{206} \mathrm{~Pb}$ as the Hannum Creek deposit. Furthermore, Devonian SEDEX-type deposits in the Wood River district of Idaho (Hall and others, 1978) contain much more radiogenic $\mathrm{Pb}$ than does the Hannum Creek deposit. Red Dog and Drenchwater Creek SEDEX-type deposits of Mississippian and Pennsylvanian age in the DeLong Mountains (Lange and others, 1980) contain much less radiogenic $\mathrm{Pb}$ than Hannum Creek.

The Wheeler prospects, first described by Smith (1908), are small lode deposits containing galena, chalcopyrite, pyrite, bornite, and sphalerite in schist and marble of the Nome Group. Poorly exposed lead prospects on the east side of the Kruzgamepa River, near the mouth of Iron Creek, were examined during this study. Pyrite is common, occurring as folded layers and as veinlets, stringers, and disseminations in interlayered marble and calcareous muscovite schist. Finely crystalline galena was found in marble talus. Other minerals present include ankerite(?), magnetite, and traces of fluorite. Mineralization is apparently controlled by faulting.

$\mathrm{Pb}$-isotope analysis of a single galena from the Wheeler prospects gave $\mathrm{Pb}$-isotopic results identical to those from the Red Dog and Drenchrrater Creek deposits (Lange and others, 1980; Lueck, 1981) that occur in Mississippian strata in the DeLong Mountains and Howard Pass quadrangles (?ailleur and others, 1977) north of Seward Peninsula. Two alternatives are possible to explain the $\mathrm{Pb}$-isotopic data: (1) the deposit represents SEDEX-type mineralization similar to that of the Red Dog deposit; or (2) the deposit is magmatic-hydrothermal in origin, and the analyzed sample reflects a sediment- $\mathrm{Pb}$ signature from the host rocks. Clarification of these alternatives may be possible with additional field and isotopic work.

\section{REFERENCES CITED}

Bundtzen, T.K., 1974, Geochemistry of parts of the Bendeleben A-6, A-5, A-4, B-5, ant B-4 quadrangles, Alaska: Alaskan Division of Geological and Geophysical Survey Open-File Report 39, $7 \mathrm{p}$.

Doe, B. R., 1970, Lead Isotopes: Minerals, Rocks, and Inorganic Materials, v. 3. Heidelberg, Springer-Verlag, $137 \mathrm{p}$.

Hall, W. E., Rye, R. O., and Doe, B. R., 1978, Stable isotope and fluid inclusion studies of the Wood River district, south-central Idaho: U.S. Geological Survey Journal of Research, v. 6, p. 579592.

Hudson, Travis, and Arth, J. G., 1983, Tin granites of Seward Peninsula, Alaska: Geological Society of America Bulletin, v. 94, p. 768-790.

Godwin, C. I., and Sinclair, A. J., 1982, Average lead isotope growth curves for shale-hosted zinc-lead deposits, Canadian Cordillera: Economic Geology, v. 77, p. 675-690.

King, H. D., 1984, Geochemical survey of the Soloman and Bendeleben quadrangles, Seward Peninsula, Alaska, in Reed, K. M., and BartschWinkler, Susan, eds., The United States Geological Survey in Alaska-Accomplishments during 1982: U.S. Geological Survey Circular 939, p. $33-37$.

Lange, I. M., Nokleberg, W. J., Plahuta, J. T., Krouse, H. R., Doe, B. R., and Jansons, Uldis, 1980 , Isotopic geochemistry of stratiform zinclead-barium deposits, Red Dog Creek and Drenchwater Creek areas, northwestern Brooks Range, Alaska, in Silberman, M. L., Field, C. W., and Berry, A. L., Proceedings of the symposium on mineral deposits of the Pacific Northwest-1980: U.S. Geolog: nal Survey Open-File Report 81-355, p. 1-16.

Lueck, Larry, 1981, Lead isotope ratios from the Red Dog and Drenchwater Creek lead-zinc deposits, DeLong Mountains, Bro oks Range, 
Alaska: in Short Notes on Alaskan Geology, Alaska Division of Geological and Geophysical Surveys Geologic Report 63, p. 1-15.

Miller, T. P., 1972, Potassium-rich alkaline intrusive rocks of western Alaska: Geological Society of America Bulletin, v. 83, p. 2111-2128.

Miller, T. P., and Bunker, C. M., 1976, A reconnaissance study of the uranium and thorium contents of plutonic rocks of southeastern Seward Peninsula, Alaska: U.S. Geological Survey Journal of Research, v. 4, no. 3, p. 367-377.

Mulligan, J. J., 1962, Lead-silver deposits in the Omilak area, Seward Peninsula, Alaska: U.S. Bureau of Mines Report of Investigations 6018, $44 \mathrm{p}$.

Sainsbury, C. L., 1964, Geology of the Lost River Mine area, Alaska: U.S. Geological Survey Bulletin 1129, $80 \mathrm{p}$.

Sainsbury, C. L., 1969, Geology and ore deposits of the central York Mountains, western Seward Peninsula, Alaska: U.S. Geological Survey Bulletin 1287, $101 \mathrm{p}$.

Smith, P. S., 1908, Investigations of the mineral deposits of Seward Peninsula, in Brooks, A. H. and others, Mineral resources of Alaska-Report on progress of investigations in 1907: U.S. Geological Survey Bulletin 345, p. 206-250.

Stacey, J. S., and Kramers, J. D., 1975, Approximation of terrestrial lead isotope evolution by a two-stage model: Earth and Planetary Science Letters, v. 26, p. 207-221.

Till, A. B., 1983, Granulite, peridotite, and blueschist: Precambrian to Mesozoic history of Seward Peninsula: Journal of the Alaska Geological Society, Symposium Proceedings, v. 3, p. 59-66.

Tailleur, I. L., Ellersieck, I. F., and Mayfield, C. F., 1977, Mineral resources of the Western Brooks Range, in Blean, K. M., United States Geological Survey in Alaska-Accomplishments during 1976: U.S. Geological Survey Circular 751-B, p. 24-25.

Reviewers: H. D. King and T. D. Light

\section{PRELIMINARY STUDY OF LODE GOLD DEPOSITS, SEWARD PENINSULA}

\section{Bruce M. Gamble, Roger P. Ashley, and William J. Pickthorn}

Although important placer gold deposits are widely distributed on the Seward Peninsula, known lode gold deposits are small and have a more limited distribution. Lodes occur south of the Kigluaik and Bendeleben Mountains in blueschist-facies rocks of the Nome Group (fig. 21) (Moffit, 1913; Till, 1984). Amphibolite- and granulite-facies rocks and plutonic rocks exposed in the Kigluaik, Bendeleben, and Darby Mountains contain no known gold deposits,

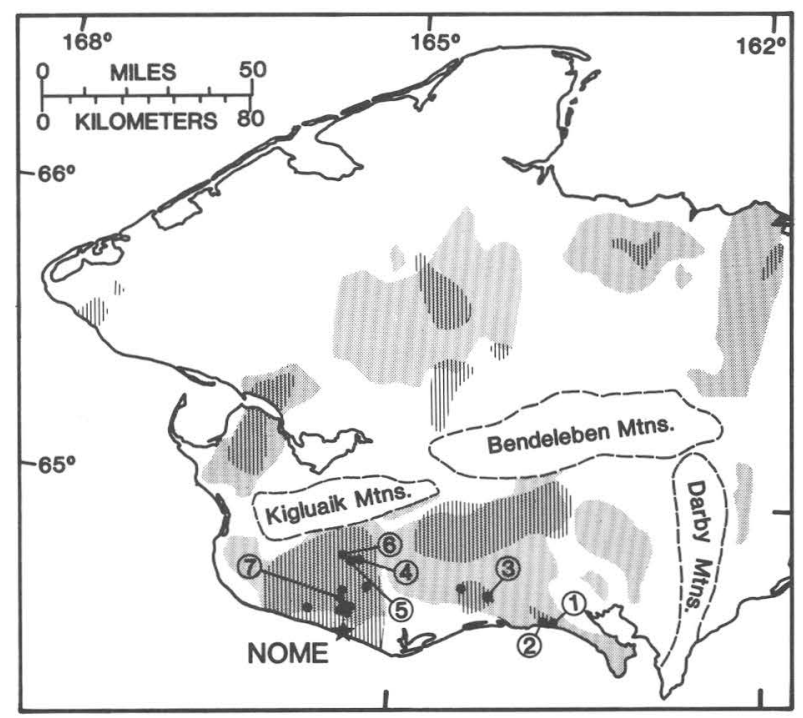

Figure 21.--Distribution of lode gold occurrences (circles), placer gold regions (line pattern) and the Nome Group (dot pattern) on the Seward Peninsula. Numbers indicate lodes discussed in text: 1, Koyana Creek; 2, Bluff; 3, Big Hurrah; 4, Sliscovitch; 5, McDuffee; 6, California; 7, Stipec \& Kotovic, and Sophie Gulch.

with the exception of a few silver-base metal deposits that have minor gold.

The Nome Group includes four mappable lithologic units. These are, from structurally lowest to highest: (1) pelitic schist with subordinate marble; (2) a lithologically inhomogenous unit containing interlayered carbonaceous quartzite, marble, impure marble, and quartz-mica schist (the mixed unit); (3) mafic schist with subordinate calcareous material; and (4) chloritic marble. Lenses and layers of metabasite are common in the mafic schist unit and are found locally in the mixed and chloritic marble units (Till, 1984). Blueschist-facies mineral assemblages are best preserved in the metabasites. The Nome Group was subjected to a monocyclic, polyphasic, metamorphic event that initially underwent penetrative deformation under blueschistfacies conditions prior to more passive greenschistfacies conditions (Thurston, 1983). This event probably occurred in Late Jurassic or Early Cretaceous time (Forbes and others, 1984). The dominant metamorphic assemblage present in the Nome Group is blueschist facies. Greenschist-facies recrystallization was incomplete; examples include static recrystallization of chlorite after garnet and chloritoid, and rare development of biotite.

Lodes examined in this study were previously described by Cathcart (1922). Information presented here on the origin of the lode gold occurrences and their relation to the metamorphic stratigraphy of Till (1984) results from field data collected in 1983 and 1984, and laboratory analyses of $60 \mathrm{sam}-$ ples from the deposits and surrounding areas. 
Table 6.--Results of analyses of gold-quartz veins from the Seward Peninsula. All values are in parts-per-million (ppm). Detection limits are in parentheses (Ag analysis by semiquantitative emission spectrography; $\mathrm{Au}, \mathrm{As}, \mathrm{Bi}$, and $\mathrm{Sb}$ by atomic absorption). N, not detected; $\mathrm{L}$, present, but below detection limit; G, greater than; ${ }^{*} \mathrm{G}$, much greater than

\begin{tabular}{cccccc}
\hline Deposit & $\begin{array}{c}\mathrm{Au} \\
(0.05)\end{array}$ & $\begin{array}{c}\mathrm{Ag} \\
(0.05)\end{array}$ & $\begin{array}{c}\mathrm{As} \\
(10)\end{array}$ & $\begin{array}{c}\mathrm{Bi} \\
(1)\end{array}$ & $\begin{array}{c}\mathrm{Sb} \\
(2)\end{array}$ \\
\hline McDuffee & 120 & 10 & 280 & $\mathrm{~N}$ & 6 \\
& 4.0 & $\mathrm{~N}$ & 450 & $\mathrm{~N}$ & 4 \\
Sliscovitch & $\mathrm{N}$ & $\mathrm{L.5}$ & 350 & $\mathrm{~N}$ & 6 \\
& 6.5 & 7 & 250 & $\mathrm{~N}$ & $* \mathrm{G} 1,000$ \\
California & 4.4 & 2 & 100 & $\mathrm{~N}$ & $* \mathrm{G} 1,000$ \\
& .05 & $\mathrm{~N}$ & 510 & $\mathrm{~N}$ & 18 \\
Stipec \& & .15 & $\mathrm{~N}$ & 700 & $\mathrm{~N}$ & 18 \\
Kotovic & .20 & 5 & $\mathrm{G} 2,000$ & $\mathrm{~N}$ & 80 \\
Bluff & 1.0 & $\mathrm{~N}$ & 1,300 & $\mathrm{~N}$ & $\mathrm{~N}$ \\
& 1.2 & $\mathrm{~N}$ & $\mathrm{G} 2,000$ & $\mathrm{~N}$ & 2 \\
Koyana & 40 & 10 & 48,000 & 10 & 350 \\
Creek & .05 & 5 & $\mathrm{G} 2,000$ & $\mathrm{~N}$ & $\mathrm{G} 1,000$ \\
Big Hurrah & 4.0 & 2 & $\mathrm{G} 2,000$ & 14 & 540 \\
& 9.1 & 7 & 27,000 & $\mathrm{~N}$ & 54 \\
& 31 & 10 & 54,000 & 6 & 160 \\
& 25 & $\mathrm{~L} .5$ & 60 & $\mathrm{~L} 2$ & 6 \\
& 65 & 10 & 30 & $\mathrm{~L} 2$ & 4 \\
& 16 & 1 & 65,000 & $\mathrm{~L} 2$ & 200 \\
\hline
\end{tabular}

Lode gold deposits occur in the mixed unit and the mafic schist unit and are mostly quartz veins formed along high-angle faults which cut the generally shallow-dipping metamorphic foliation. Most of these faults belong to two regional sets that trend northeast and northwest. Veins range from $2 \mathrm{~cm}$ to $5 \mathrm{~m}$ in width ; most are less than $10 \mathrm{~cm}$ wide. In addition to quartz, they typically contain minor carbonate and albite or oligoclase. Free gold is accompanied by arsenopyrite and lesser pyrite but is not necessarily in contact with these minerals. Total sulfide content is usually less than a few percent. Minor chalcopyrite, sphalerite, stibnite, tetrahedrite(?) and scheelite may also be present. Samples of vein material contain up to $120 \mathrm{ppm} \mathrm{Au}$, 6.5 percent $\mathrm{As}, 10 \mathrm{ppm} \mathrm{Ag}$, and greater than $1,000 \mathrm{ppm} \mathrm{Sb}$ (table 6); some samples contain up to $50 \mathrm{ppm} \mathrm{W,} 200 \mathrm{ppm} \mathrm{Cu}, 330 \mathrm{ppm} \mathrm{Zn,} 50 \mathrm{ppm}$ Mo, or $14 \mathrm{ppm} \mathrm{Bi}$. Lenticular masses of mineralized quartz that are conformable with the enclosing metamorphic rocks are reported as "older veins" (Brooks, 1908 , p. 117; Smith, 1910, p. 91). Samples of boudins adjacent to veins at the McDuffee prospect showed no detectable Au at a $50 \mathrm{ppb}$ detection limit, and quartz boudins sampled at localities away from known vein occurrences similarly had no detectable $\mathrm{Au}$. It is not clear what relationship, if any, these older veins have to the crosscutting gold-quartz veins.

Gold localities examined include several sulfide-rich types of occurrences in addition to the more typical low-sulfide veins. Two quartz veins at Bluff contain as much as 60 percent arsenopyrite, and a vein at Big Hurrah has 10-15 percent arseno-

pyrite. Quartz-stibnite veins observed at two localities (Gray Eagle, Sliscovitch) locally contain 50 percent stibnite and minor pyrite.

Veins at the Big Hurrah Mine are the largest known on the Seward Peninsula. Approximately $810 \mathrm{~kg}(26,000 \mathrm{oz})$ of gold have been extracted from the Big Hurrah, mostly between 1903 and 1909 . The property has been actively explored for additional reserves in recent years. At least four, and possibly six, lodes are present. Each lode is a fault zone containing as many as four veins (C. C. Hawley, Hawley and Associates Inc., Anchorage, written commun., 1985). Individual veins range from 0.5 to $5.0 \mathrm{~m}$ in width; most are less than $1 \mathrm{~m}$ wide. Fault zones that form the lodes strike northwest and most dip steeply to the southwest. The country rock is quartz-rich, carbonaceous mica schist or quartzite of the mixed unit. Preliminary fluid inclusion studies of the Big Hurrah veins by John J. Read (Washington State University, Pullman, written commun., 1985) show that inclusions in gold-bearing quartz samples have low salinities (2-5 weight percent $\mathrm{NaCl}$ equivalent) and contain significant $\mathrm{CO}_{2}$ and some $\mathrm{CH}_{4}$.

Oxygen-isotope measurements were made on samples of vein quartz from three lode gold occurrences in the Nome district and on quartz from the mineralized area at the Big Hurrah Mine (table 7). Samples from two quartz-calcite boudins at the McDuffee prospect in the Nome district were also analyzed. The high $\delta^{18} \mathrm{O}$ values for the five quartz vein samples from the Nome area $(+15.4$ permil to +19.2 permil) suggest that gold-bearing quartz was deposited from a metamorphic fluid; i.e., from 
Table 7.--Oxygen-isotope $\left(\delta^{18} \mathrm{O}\right)$ values for quartz from boudins and gold-bearing veins, Seward Peninsula. Values are reported in permil relative to Standard Mean Ocean Water (SMOW)

\begin{tabular}{lc}
\hline Deposit & $\delta^{18} 0$ values \\
\hline Nome area gold-bearing veins & \\
McDuffee prospect & $+19.2,+19.1,+18.4$ \\
$\quad$ Stipec \& Kotovic prospect & +15.4 \\
Sophie Gulch prospect & +17.9 \\
Big Hurrah mine; vein exposed & \\
$\quad$ in pit at northeast end & \\
of mineralized area & +10.2 \\
McDuffee prospect boudins & \\
1 m from footwall of vein & +13.9 \\
0.1 m from footwall of vein & +15.3 \\
\hline
\end{tabular}

water which equilibrated isotopically with sedimentary and (or) volcanic rocks under greenschist- to amphibolite-facies temperature conditions (Taylor, 1979; Fyfe and Kerrich, 1984). At the McDuffee prospect, quartz from a boudin located $1 \mathrm{~m}$ from the nearest gold-bearing quartz vein has a $\delta^{18} \mathrm{O}$ value of +13.9 permil, which is in the range typical of metamorphic quartz segregations in greenschistfacies rocks. Quartz from a boudin located only $10 \mathrm{~cm}$ from the nearest gold-bearing vein has a $\delta^{18} \mathrm{O}$ value of +15.3 permil, which could be the result of a fluid with $\delta^{18} \mathrm{O}$ of about +19 permil migrating outward from the vein and interacting with previously equlibrated, isotopically lighter boudin quartz. The relatively low $\delta{ }^{18} \mathrm{O}$ value $(+10.2$ permil) for the quartz sample from the Big Hurrah Mine area, though equivocal, could be produced by metamorphic fluid that equilibrated with carbonrich rocks, such as those common around the Big Hurrah, under greenschist-facies conditions.

Isotopic and fluid-inclusion composition data suggest that gold lode deposits on the Seward Peninsula were formed from fluids that equilibrated with sedimentary and (or) volcanic protoliths of the Nome Group under greenschist-, blueschist-, or amphibolite-facies conditions. The fluids then moved upward during the later, post-kinematic part of the metamorphic event and deposited gold- and sulfide-bearing quartz veins in fractures and fault zones.

\section{REFERENCES CITED}

Brooks, A. H., 1908, Outline of economic geology, in The gold placers of parts of the Seward Peninsula, Alaska: U.S. Geological Survey Bulletin 328, p. 111-139.

Catheart, S. H., 1922, Metalliferous lodes in southern Seward Peninsula, Alaska: U.S. Geological Survey Bulletin 722-F, p. 163-261.

Forbes, R. B., Evans, B. W., and Thurston, S. P., 1984, Regional progressive high-pressure metamorphism, Seward Peninsula, Alaska: Journal of Metamorphic Geology, v. 2, no. 2, p. 43-54.
Fyfe, W. S., and Kerrich, R. 1984, Gold: Natural concentration processes, in Foster, R. P., ed., Gold '82, The Geology, Geochemistry, and Genesis of Gold Deposits: Rotterdam, A. A. Balkema, p. 99-127.

Moffit, F. H., 1913, Geology of the Nome and Grand Central quadrangles, Alaska: U.S. Geological Survey Bulletin 533, $140 \mathrm{p}$.

Smith, P. S., 1910, Geology and mineral resources of the Solomon and Casadepaga quadrangles, Seward Peninsula, Alaska: U.S. Geological Survey Bulletin 433, $234 \mathrm{p}$.

Taylor, H. P., 1979, Oxygen and hydrogen isotope relationships in hydrothermal mineral doposits: in Barnes, H. L., ed: Geochemistry of Hydrothermal Ore Deposits, 2nd edition, Ner" York, John Wiley and Sons, p. 236-277.

Thurston, S. P., 1983, High-pressure metamorphism and coexisting amphiboles in the Nome Group schists, Seward Peninsula, Alaska (abs.): Geological Society of America Abstracts with Programs, v. 16, no. 5, p. 437.

Till, A. B., 1984, Low-grade metamorphic rocks, Seward Peninsula, Alaska (abs.): Geological Society of America Abstracts with Programs, v. 16 , no. 5 , p. 357 .

Reviewers: J. M. Schmidt and A. B. Till

\section{EAST-CENTRAL ALASKA}

(Figure 22 shows study areas described.)

\section{PRELIMINARY STUDY OF SHEAR SENSE IN MYLONITES, EASTERN RAY MOUNTAINS, TANANA QUADRANGLE}

\section{Ronny T. Miyaoka and James H. Dove*}

An attempt was made, using oriented thin sections, to determine the sense of shear recorded in the mylonitic fabric of rocks in the eastern Ray Mountains (fig. 23) in order to better understand the relative movement between two major rock pack- 


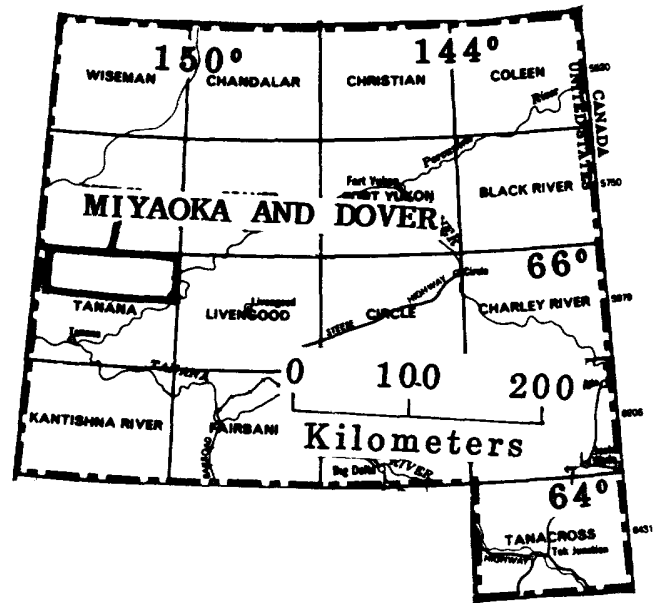

Figure 22.--Map showing areas in east-central Alaska discussed in this circular.

ages--the metamorphic suite of the Ray Mountains and the Rampart assemblage (Dover and Miyaoka, 1985a). The Ray Mountains unit is part of the Ruby terrane of Silberling and Jones (1984) and is composed of undated polymetamorphosed metasedimentary and metaigneous rocks of continental affinity (Chapman and others, 1982; Dover and Miyaoka, 1985a). The Rampart assemblage is part of the Tozitna terrane of Silberling and Jones (1984) and is a sequence of mafic igneous and sedimentary rocks of Devonian(?) to Triassic age. The rock unit studied (Ds; fig. 1) is composed predominantly of mylonitic, medium- to fine-grained quartz wacke and finely sheared quartz-rich siltstone of Devonian(?) age within the lower part of the Rampart assemblage. Unit Ds generally has a moderate to gentle southeasterly dipping mylonitic foliation which could have been formed by either northwest(up-dip)or southeast(down-dip)-directed tectonic movement of the Rampart assemblage relative to the Ray Mountains unit (Dover and Miyaoka, 1985b). Assuming that the mylonitic fabric was produced by movement between the Rampart assemblage and Ray Mountains unit, it was the aim of this study to determine if fabric analyses could be used to determine which sense of movement occurred. Knowledge of the sense of movement (i.e., whether the Rampart assemblage moved up-dip over the Ray Mountains unit from the southeast or down-dip from the northwest) is critical to the regional tectonic reconstruction of interior Alaska.

Criteria used in this study are mainly composite planar fabries and asymmetric augen structures (fig. 24) as summarized by Simpson and Schmid (1983). Composite planar fabrics involve the relationship between flattening (S) foliation and shear (C) foliation (Berthe and others, 1979; see also Simpson, 1984, figs. 24 a,b,c). Asymmetric augen structures occur where fine-grained recrystallized parts of megacrysts are dragged out along the shear foliation (Simpson and Schmid, 1983, fig. 4A). Ro- tation of porphyroblastic plagioclase is the other textural criteria considered in this study.

It should be noted that the $\mathrm{S}$ and $\mathrm{C}$ foliations considered occur in layered metasedimentary rocks that underwent ductile shearing imposed by regional thrusting, whereas the original work b-r Berthe and others (1979) on S and C foliations wa in isotropic granite sheared by strike-slip faultinr. Work by Simpson (1984) was also on a sheered granite, though the shearing resulted from thrust faulting. Consistent results were obtained by Brown and Murphy (1982) in applying the $\mathrm{S}$ and $\mathrm{C}$ criteria to ductily sheared metasedimentary roc'ss. In that study, mylonitic foliation in the metasedimentary rocks was interpreted as transposed compositional layering. The same interpretation is made here.

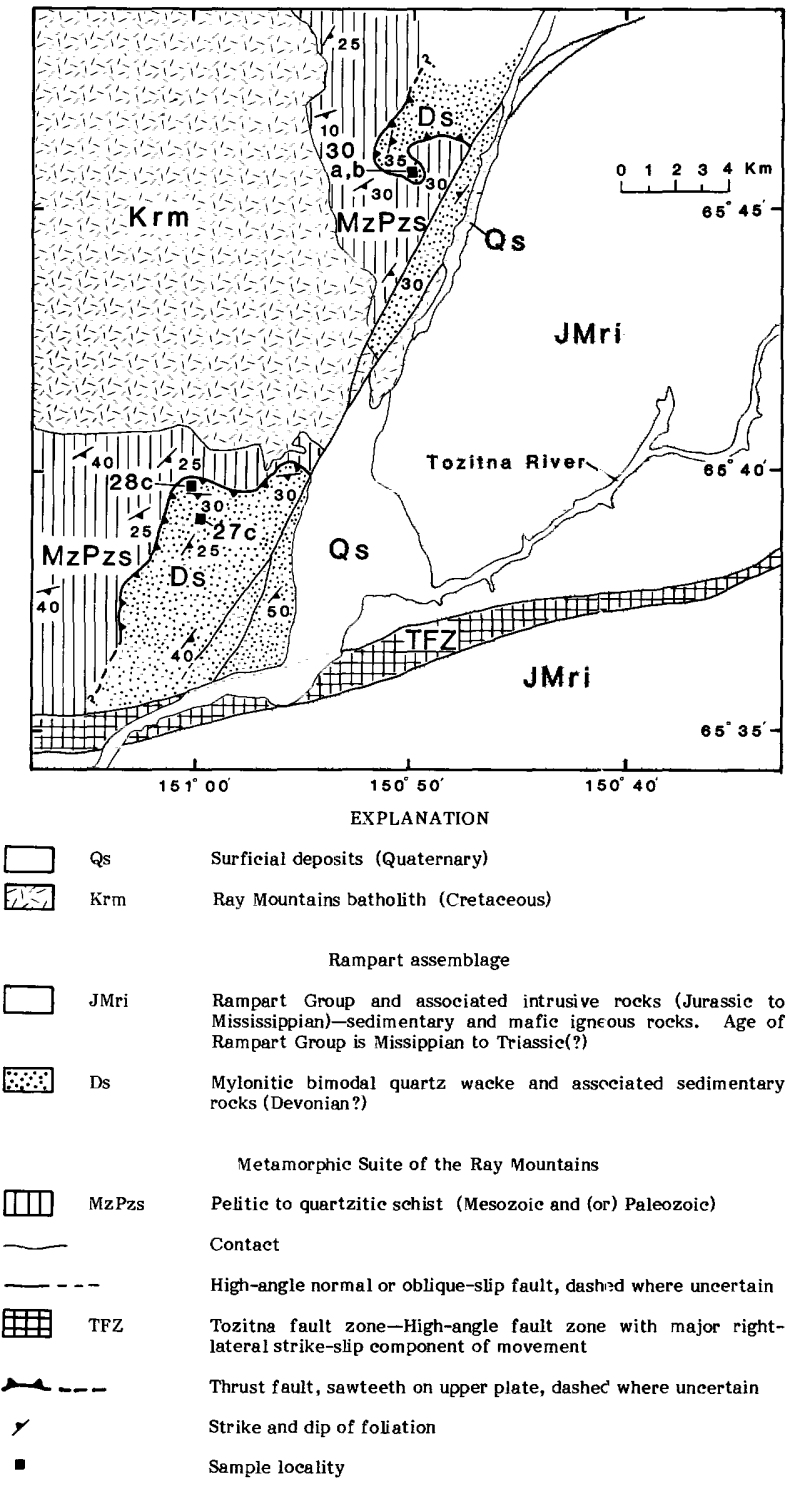

Figure 23.--Geology of the eastern Rey Mountains area showing sample locations. 
Four oriented samples were collected within unit Ds in 1984 (fig. 23). Figure 25 shows the relationship between foliation, lineation, and orientation of thin sections. Lineation is defined by elongate streaks of quartz and (or) feldspar aggregates. Down-dip orientation of lineation is considered to have formed by mineral stretching in a direction parallel to shearing (Berthe and others, 1979; Brown and Murphy, 1982; Simpson and Schmid, 1983); therefore, only sections cut parallel to the stretching lineation were studied in order to determine the sense of shear.

Thin sections were examined systematically using a mechanical stage, and the sense of shear was recorded for the fabric element present (fig. 24). Sample 27c has asymmetric augen structures and $\mathrm{S}$ and $\mathrm{C}$ foliations which consistently indicate an up-dip sense of shear, and sparse, rotated, plagioclase porphyroblasts which give ambiguous results. Sample $28 \mathrm{c}$ has $\mathrm{S}$ and $\mathrm{C}$ foliations which indicate down-dip shear and sparse, asymmetric, augen structures which also give an ambiguous sense of

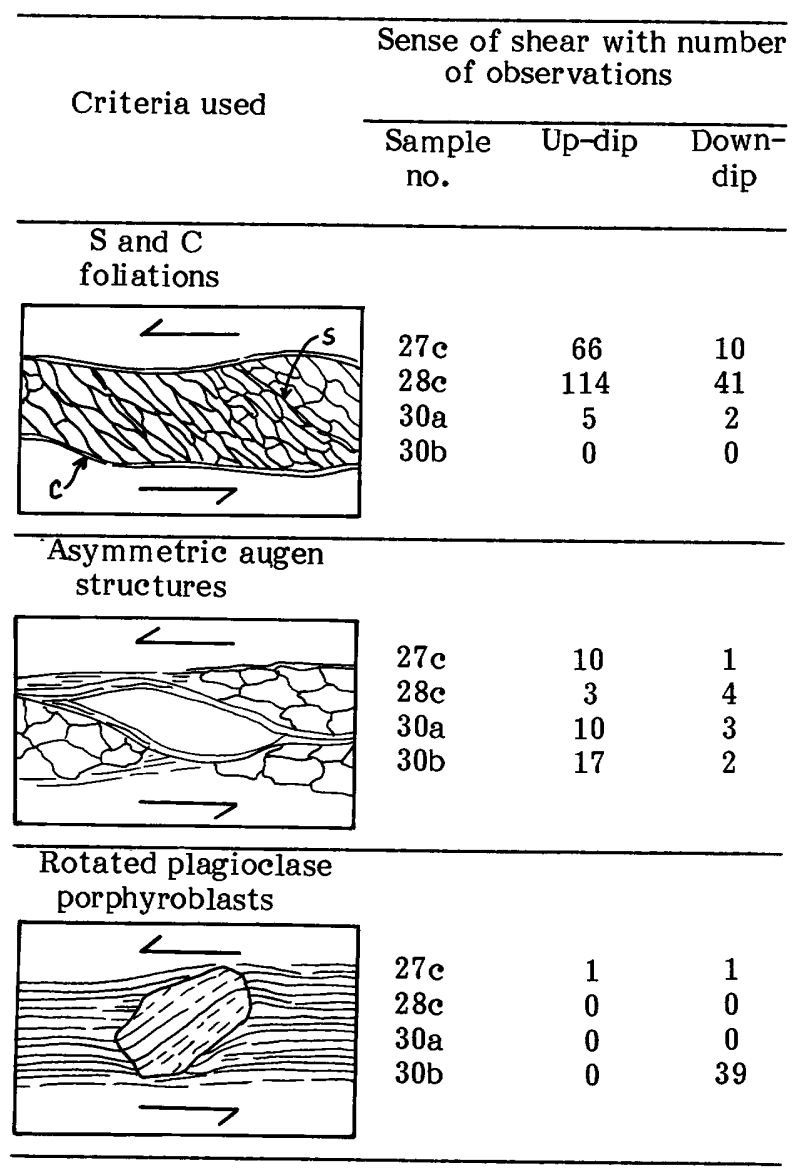

Figure 24.--Sketches of thin section observations illustrating criteria. The number of observations for each shear sense is given. sinistral shear. shear. Sample 30a contains asymmetric augen structures and $\mathrm{S}$ and $\mathrm{C}$ foliations which indicate an up-dip sense of shear; however, both criteria are sparse. Sample $30 \mathrm{~b}$ contains asymmetr $: ?$ augen structures that consistently indicate an up-dip sense of shear, but rotated plagioclase porph-roblasts which consistently indicate a down-dip shear sense. The contradictory nature of the d?ta from sample $30 \mathrm{~b}$ reflect, in part, the poor develomment of the fabric elements but may also indicate our incomplete understanding of those elements.

Because of data inconsistencies, the sense of shear in the mylonites of the eastern Ray Mountains has not been clearly demonstrated in this preliminary study. Nevertheless, the preponderance of $\mathrm{S}-\mathrm{C}$ and asymmetric augen data, where best developed, indicate an up-dip sense of shear, suggesting movement of the Rampart assemblage from southeast to northwest over the metamorphic suite of the Ray Mountains. We expect our continuing study of Rampart assemblage-metamorphic suite of the Ray Mountains relations to be enhanced by more thorough sampling and by more careful selection of coarser grained porphyroclastic material, where possible. Microfabric analysis appears to be a promising approach to this kind of problem ir Alaska, where the relative motions of many terranos are in question.

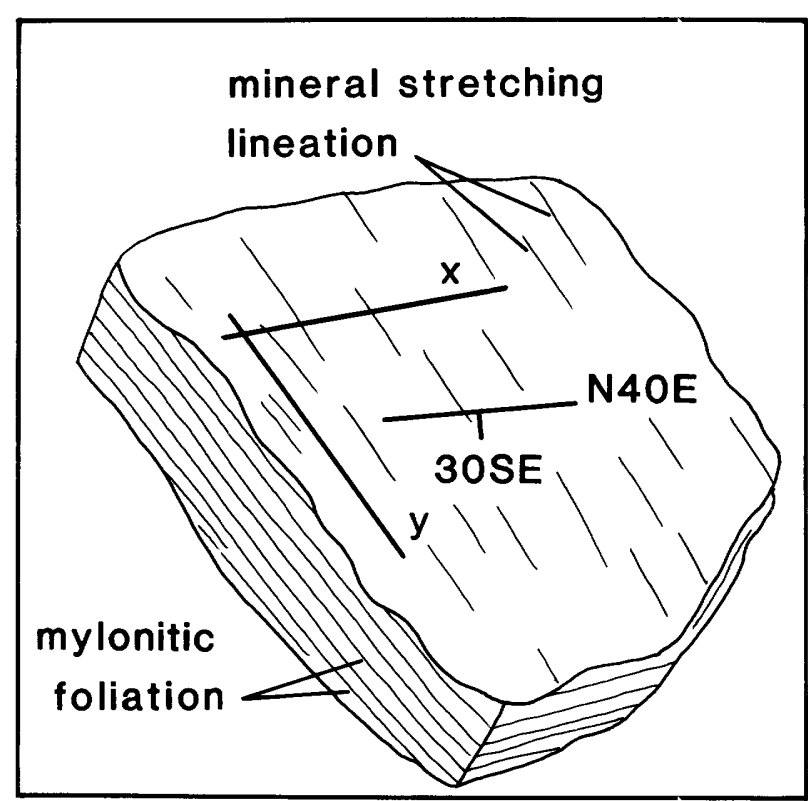

Figure 25.--Sketch of sample $28 \mathrm{c}$ showing st:etching lineation, strike and dip of mylonitic foliation, and lines (marked $\mathrm{x}$ and $\mathrm{y}$ ) drawn to indicate wrere thin sections were to be cut. Only the sections cut parallel to the stretching lineation (y sections) were studied to determine shear sense. 


\section{REFERENCES CITED}

Berthe, D., Choukroune, P., and Jegouzo, P., 1979, Orthogneiss, mylonite and non-coaxial deformation of granites: the example of the South Amörican Shear Zone: Journal of Structural Geology, v. 1, p. 31-42.

Brown, R.L., and Murphy, D.C., 1982, Kinematic interpretation of mylonitic rocks in part of the Columbia River fault zone, Shuswap terrane, British Columbia: Canadian Journal of Earth Sciences, v. 19, p. 456-465.

Chapman, R.M., Yeend, Warren, Brosge, W.P., and Reiser, H.N., 1982, Reconnaissance geologic map of the Tanana quadrangle, Alaska: U.S. Geological Survey Open-File Report 82-734.

Dover, J. H., and Miyaoka, R. T., 1985a, Major rock packages of the Ray Mountains, Tanana and Bettles quadrangles; in Bartsch-Winkler, Susan, and Reed, K. M., eds., The United States Geological Survey in Alaska-Accomplishments during 1983: U. S. Geological Survey Circular 945, p. 32-36.

Dover, J. H., and Miyaoka, R. T., 1985b, Metamorphic rocks of the Ray Mountains--Preliminary structural analuysis and regional tectonic implications; in Bartsch-Winkler, Susan, and Reed, K. M., eds., The United States Geological Survey in Alaska-Accomplishments during 1983: U. S. Geological Survey Circular 945, p. 36-38.

Silberling, N.J., and Jones, D.L., eds., 1984, Lithotectonic terrane maps of the North American Cordillera: U.S. Geological Survey Open-File Report 84-523.

Simpson, Carol, and Schmid, S.M., 1983, An evaluation of criteria to deduce the sense of movement in sheared rocks: Geological Society of America Bulletin, v. 94, p. 1281-1288.

Simpson, Carol, 1984, Borrego Springs-Santa Rosa mylonite zone: A Late Cretaceous west-directed thrust in southern California: Geology, v. 12, p. 8-11.

Reviewed by S.W. Nelson and A.B. Till

\section{SOUTHWESTERN ALASKA}

(Figure 26 shows study areas described.)

\section{TERRANE ANALYSIS \\ OF THE NORTHERN BRISTOL BAY REGION, SOUTHWESTERN ALASKA}

\section{Stephen E. Box}

The northern Bristol Bay region of southwestern Alaska is a structurally complex area of predominantly volcanic and volcaniclastic rocks. Earlier 1:250,000-scale mapping (Hoare and Coonrad, 1959; 1961a, b; 1978) resulted in subdivision of this region into four tectonostratigraphic terranes: the Togiak, Goodnews, Kilbuck, and Nyack terranes (Jones and others, 1981). In this report, some of the terrane boundaries have been

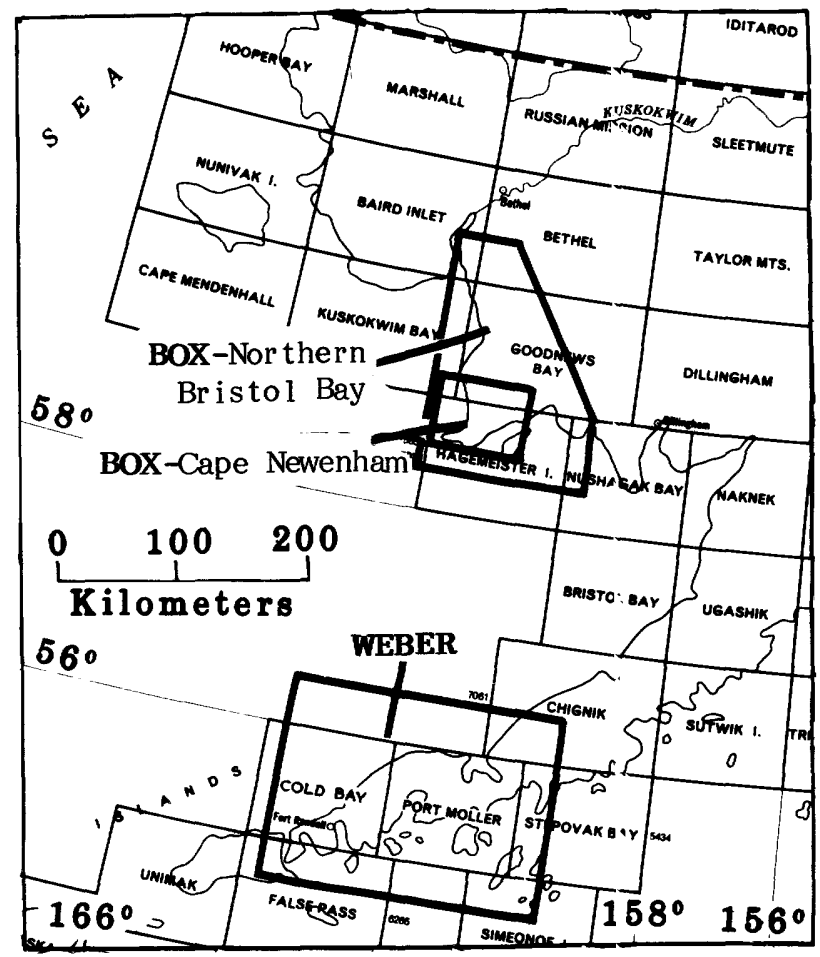

Figure 26.--Map showing areas in southwestern Alaska discussed in this circular.

modified, and two of the terranes (Togiak and Goodnews) have been subdivided into compcnent subterranes. These changes are based on recent mapping of the coastal outcrop belt (Box, 1985a), a traverse down the Kanektok River, and review of the field notes of J. M. Hoare and W. L. Coonrad (1951-53; 1974-76) for the interior parts of the mapped area. More extensive documentation of the following analysis is reported elsewhere (Box, 1985a). Seven terranes and subterranes are shown in figure 27; generalized stratigraphic columns for each are shown in figure 28. Characteristics of terrane boundaries and constraints on the age of major motion across them are summarized in table 8.

The Togiak terrane consists of Mesozoic volcanic and volcaniclastic rocks that are separated aerially into the Kulukak and Hagemeister subterranes (Box, 1985a). The Kulukak subtermane, on the southeast, consists predominantly of volcaniclastic turbidites of Jurassic age (Kulukak greywacke unit of Hoare and Coonrad, 1978), as well as the Upper Cretaceous Summit Island Formation and unnamed Late Cretaceous and early Tertiary intrusive and volcanic rocks. Dismembered Lower Jurassic strata ("broken formation") are unconformably overlain by concentrically folded Middle and Upjer Jurassic strata. Late Early Jurassic deformation is characterized by southeastward vergence, while earliest Cretaceous deformation resulted in northwestward thrusting of the Kulukak subterrane over the Hagemeister subterrane. The Hagemeister subterrane consists of Upper Triassic through Lower 


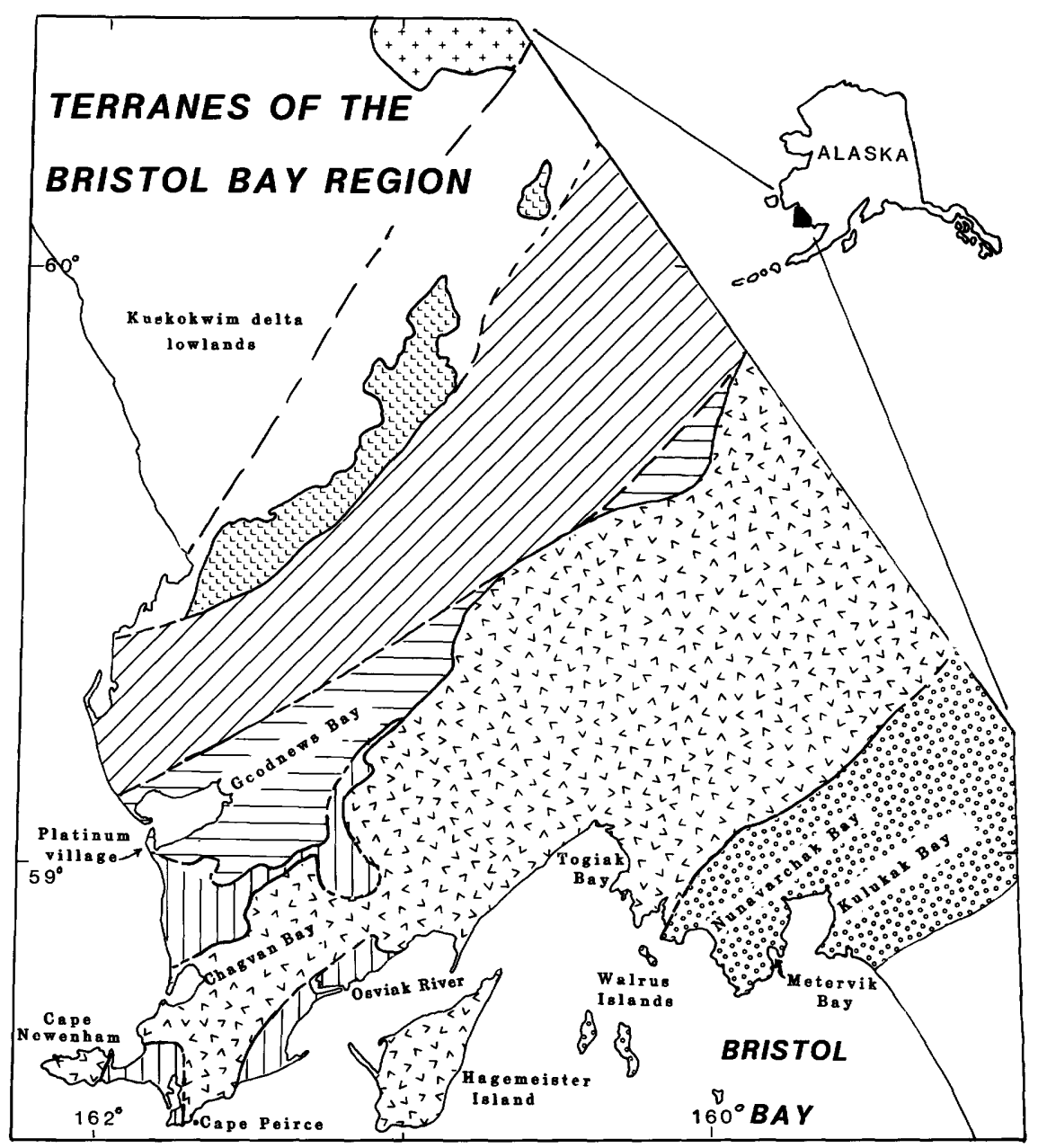

EXPLANATION

Goodnews terrane--Consists of:

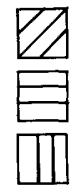

Nukluk subterrane

Platinum subterrane

Cape Peirce subterrane
Togiak terrane--Consists of:

\begin{tabular}{|c|c|}
\hline $\begin{array}{l}v<1 \\
1 \\
v>\lambda\end{array}$ & Hagemeister subterrane \\
\hline$\left[\begin{array}{ll}\because & 0 \\
0 & 0\end{array}\right.$ & Kulukak subterrane \\
\hline
\end{tabular}

$\left[\begin{array}{l}++ \\ ++\end{array}\right]$ Nyack terrane

Kilbuck terrane

Figure 27.--Terranes and subterranes of the northern Bristol Bay region of southwestern Alaska (modified from Jones and others, 1981). 


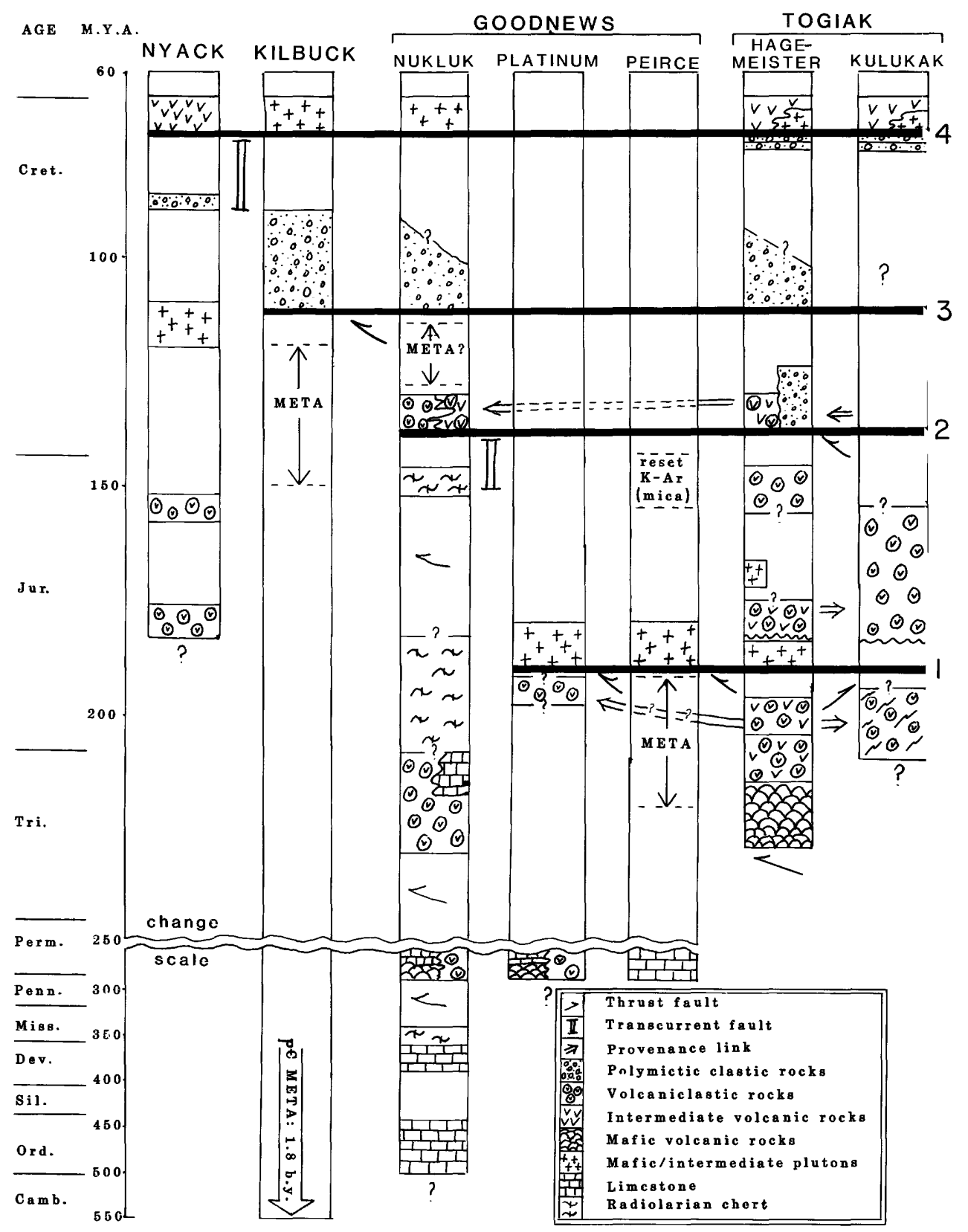

Figure 28.--Stratigraphic columns of terranes and subterranes shown in figure 27. Timing of terrane linkages shown by bold horizontal lines; numbers keyed to table 8. Geologic time scale from Palmer (1983).

Cretaceous strata separated into three units by angular unconformities of late Early Jurassic and earliest Cretaceous age (Box, 1985a). The lower unit consists of a mafic igneous suite intercalated with Upper Triassic chert (Box, 1985c), which grades upward into Lower Jurassic shallow marine volcaniclastic rocks. The middle and upper units consist of intermediate composition volcanic and volcaniclastic rocks deposited in rapidly varying subaerial to deep marine environments. The upper unit (Lower Cretaceous) also overlaps the entire Goodnews terrane and contains detritus from the adjacent Kulukak subterrane. Thus, the entire Goodnews and Togiak terranes were amalgamated by Early Cretaceous (Valanginian) time.

The Goodnews terrane is subdivided into the lithologically distinct Cape Peirce, Platinum, and Nukluk subterranes (Box, 1985a). The Cape Peirce 
Table 8.--Southwestern Alaska terrane/subterrane linkages: Characteristics and constraints

Terrane/subterrane abbreviations: $\mathrm{Ku}=\mathrm{Kulukak}, \mathrm{H}=$ Hagemeister, $\mathrm{CP}=\mathrm{Cape}$ Peirce, $\mathrm{Pl}=\mathrm{Platinum}, \mathrm{Nu}=\mathrm{Nukluk}, \mathrm{Ki}=\mathrm{Kilbuck}, \mathrm{Ny}=\mathrm{Nyack}$. Numbers in parentheses refer to numbered linkages in figure 28

\begin{tabular}{|c|c|c|c|c|c|c|}
\hline & $\mathrm{Ku}-\mathrm{H}(1)$ & $\mathrm{H}-\mathrm{CP}$ (1) & CP-Pl (1) & $\mathrm{Pl}+\mathrm{H}-\mathrm{Nu} \quad(2)$ & $\mathrm{Nu}-\mathrm{Ki}$ (3) & $\mathrm{Ki}-\mathrm{Ny} \quad(4)$ \\
\hline $\begin{array}{l}\text { LINKAGE } \\
\text { TYPE }\end{array}$ & Provenance & Pluton-stitching & Pluton-stitching & $\begin{array}{l}\text { Provenance }+ \\
\text { sedimentary } \\
\text { overlap }\end{array}$ & $\begin{array}{l}\text { Provenance + } \\
\text { sedimentary } \\
\text { overlap }\end{array}$ & $\begin{array}{l}\text { Pluton-stitching + } \\
\text { sedimentary } \\
\text { overlap }\end{array}$ \\
\hline $\begin{array}{l}\text { AGE OF } \\
\text { LINKAGE }\end{array}$ & $\begin{array}{l}\text { Early Middle } \\
\text { Jurassic } \\
\text { (Bajocian) }\end{array}$ & $\begin{array}{l}\text { Early Middle } \\
\text { Jurassic } \\
(186 \pm 5 \text { m.y.) }\end{array}$ & $\begin{array}{l}\text { Early Middle } \\
\text { Jurassic } \\
(186+5 \text { m.y.) }\end{array}$ & $\begin{array}{l}\text { Early Early } \\
\text { Cretaceous } \\
\text { (Valanginian) }\end{array}$ & $\begin{array}{l}\text { Late Early } \\
\text { Cretaceous } \\
\text { (Albian) }\end{array}$ & $\begin{array}{l}\text { Late Late } \\
\text { Cretaceous } \\
(70 \pm 5 \text { m.y. })\end{array}$ \\
\hline $\begin{array}{l}\text { YOUNGEST } \\
\text { PRE-LINKAGE } \\
\text { UNIT }\end{array}$ & $\begin{array}{l}\text { Lower } \\
\text { Jurassic }\end{array}$ & Upper Triassic & $\begin{array}{l}\text { Permian } \\
\text { (possibly Upper } \\
\text { Triassic) }\end{array}$ & $\begin{array}{l}\text { Upper Upper } \\
\text { Jurassic } \\
\text { (Tithonian) }\end{array}$ & $\begin{array}{l}\text { Lower Lower } \\
\text { Cretaceous } \\
\text { (Valanginian) }\end{array}$ & $\begin{array}{l}\text { Lower Upper } \\
\text { Cretaceous } \\
\text { (Turonian) }\end{array}$ \\
\hline $\begin{array}{l}\text { BOUNDARY } \\
\text { GEOMETRY }\end{array}$ & $\begin{array}{l}\text { NW-dipping fault } \\
\text { (overprinted } \\
\text { by Early } \\
\text { Cretaceous SE- } \\
\text { dipping fault) }\end{array}$ & Low-angle fault & $\begin{array}{l}\text { SE-dipping } \\
\text { fault }\end{array}$ & $\begin{array}{l}\text { Steep linear } \\
\text { fault }\end{array}$ & $\begin{array}{l}\text { SE-dipping } \\
\text { fault }\end{array}$ & $\begin{array}{l}\text { Steep linear } \\
\text { fault }\end{array}$ \\
\hline $\begin{array}{l}\text { KINEMATICS, } \\
\text { EVIDENCE }\end{array}$ & $\begin{array}{l}\text { SE-directed } \\
\text { fold vergence, } \\
\text { rotated bou- } \\
\text { dins }\end{array}$ & $\begin{array}{l}\text { NNE-directed } \\
\text { motion of upper } \\
\text { plate (rotated } \\
\text { fold axes) }\end{array}$ & $\begin{array}{l}\text { Reverse displace- } \\
\text { ment (i.e. high- } \\
\text { grade over low- } \\
\text { grade rocks) }\end{array}$ & Unknown & $\begin{array}{l}\text { NW-directed } \\
\text { thrusting, } \\
\text { fold over- } \\
\text { turning }\end{array}$ & Unknown \\
\hline $\begin{array}{l}\text { ASSOCIATED } \\
\text { DEFORMATION }\end{array}$ & Scaly fabric & $\begin{array}{l}\text { Mylonitization } \\
\text { and flattening } \\
\text { of CP; folding } \\
\text { of } \mathrm{H} \text { (+ fault- } \\
\text { ing) }\end{array}$ & $\begin{array}{l}\text { Mylonitization, } \\
\text { flattening of } \\
\text { CP; imbrica- } \\
\text { tion, folding } \\
\text { of Pl(?) }\end{array}$ & $\begin{array}{l}\text { Reset } \mathrm{K}-\mathrm{Ar} \\
\text { mica ages } \\
\text { in } \mathrm{CP} ; \mathrm{NW} \\
\text { thrusting } \\
\text { within } \mathrm{Ku}\end{array}$ & $\begin{array}{l}\text { Imbrication of } \\
\mathrm{Ki} \text { and } \mathrm{Nu} \\
\text { terranes }\end{array}$ & Folding of $\mathrm{Ki}$ \\
\hline $\begin{array}{l}\text { ASSOCIATED } \\
\text { METAMORPHISM }\end{array}$ & None identified & $\begin{array}{l}\text { Transitional } \\
\text { greenschist- } \\
\text { blueschist } \\
\text { facies }\end{array}$ & $\begin{array}{l}\text { Transitional } \\
\text { greenschist- } \\
\text { blueschist } \\
\text { facies }\end{array}$ & $\begin{array}{l}\text { None identi- } \\
\text { fied }\end{array}$ & $\begin{array}{l}\text { Local greenschist, } \\
\text { transitional } \\
\text { greenschist- } \\
\text { blueschist facies }\end{array}$ & None identified \\
\hline
\end{tabular}


subterrane consists of foliated rocks of transitional blueschist-greenschist metamorphic facies of Late Triassic or Early Jurassic age (Box, 1985c). It is exposed under a low-angle fault beneath the Hagemeister subterrane. The Cape Peirce subterrane is thrust over the Platinum subterrane to the northwest. The Platinum subterrane consists of unfoliated Permian basalts, limestones, and volcanic conglomerate. Pre-Middle Jurassic amalgamation of the Platinum, Cape Peirce, and Hagemeister subterranes is indicated by a crosscutting belt of early Middle Jurassic mafic and ultramafic plutons (Hoare and Coonrad, 1978). The Nukluk subterrane is best described as a matrix-poor melange, whose components are shown in figure 28 (Box, 1985a; Hoare and Coonrad, 1978). Pervasive northwest-vergent imbrication is characteristic of the Nukluk subterrane. The subterrane is locally overprinted by greenschist- to blueschist-facies metamorphism along its northwestern margin. A linear fault separates the Nukluk subterrane from the Platinum and Hagemeister subterranes to the southeast. Unconformably overlying Valanginian (Lower Cretaceous) strata overstep this fault.

The Kilbuck terrane consists of foliated metamorphic rocks, which record Early Proterozoic amphibolite-facies metamorphism and an Early Cretaceous greenschist-facies retrograde event (Turner and others, in press). The Kilbuck terrane is overthrust on the southeast by the Nukluk subterrane (Box, 1985a). Albian clastic rocks overlap both the Kilbuck and Goodnews terranes but are themselves highly deformed by northwest-vergent folds.

The Nyack terrane is an area of basaltic and andesitic rocks of at least Middle and Late Jurassic age (Hoare and Coonrad, 1959). A late Early Cretaceous granitic pluton $(115+5$ m.y.) intrudes the northeastern end of the terrane (beyond the map area). The Nyack terrane is separated by a linear fault from the Kilbuck terrane to the southeast; this relationship is well-expressed in aeromagnetic data (Griscom, 1978; Dempsey and others, 1957). The earliest overlap of this boundary is by latest Cretaceous volcanic fields that are scattered across much of western Alaska (Moll and Patton, 1981). Middle Cretaceous clastic rocks apparently do not overlap the Nyack terrane.

The Mesozoic evolution of the northern Bristol Bay region is interpreted to record the growth and collisional demise of an intraoceanic volcanic arc. The Togiak terrane, characterized by long-lived, intermediate composition volcanic activity and depositional environments ranging from subaerial to deep marine, is interpreted to represent the volcanic edifice of a subduction-related volcanic arc. The character of the basal sequence of the Togiak terrane, as well as the low initial strontium isotopic ratios (0.7037-0.7041) reported from overlying, post-orogenic volcanic rocks (Globerman and others, 1984), suggest that it developed on a noncontinental base. The Goodnews terrane, characterized by high-pressure metamorphism, predomi- nance of basaltic volcanic and pelagic sedimentary components, and localized melange-like fabric, is interpreted as a subduction complex, which was structurally emplaced against and beneath the northwestern edge of the Togiak intre.oceanic arc. The apparent synchroneity of amalgamation events between the Goodnews and Togiak terranes with deformational intervals and volcanic hictuses in the Togiak terrane supports the concept that the Goodnews terrane was progressively emplaced along an active southeast-dipping (present coortinates) subduction zone. The Kilbuck terrane is interpreted as a cratonal fragment of probable North American affinity. Underthrusting of the Kilbuck terrane beneath the combined Togiak-Goodnews arc complex in Early Cretaceous time resulted in terminal arccontinent collision. The fact that amalgamation events (and presumably subduction) repeatedly occurred on the continentward flank of the intraoceanic arc suggests that this arc did not originate as an offshore arc separated from North America by a backarc basin. Its association with tr ? Early Cretaceous collision of Eurasia and North America suggests that this are may have developed offshore of the Eurasian continent (Box, 1985b). The original, post-collision position of the amalgameted KilbuckTogiak-Goodnews terranes is obscured by the apparent Late Cretaceous displacement of the Kilbuck against the Nyack terrane, another Jurassic and Cretaceous volcanic arc. The Kilbuck terrane was probably originally contiguous with the metamorphic Ruby terrane to the northeast, while the Nyack and Togiak terranes may heve originally been end-to-end continuations of a single volcanic arc trend. Late Cretaceous right-lateral faulting along northeast-trending faults (i.e., Icitarod-Nixon Fork, Susulatna lineament) may hav? sliced the amalgamated Kilbuck-Goodnews-Togiak terranes from the southeastern flank of the Ruby terrane and transported them southwestward, resulting in repetition of the are terrane.

\section{REFERENCES CITED}

Box, S. E., 1985a, Mesozoic tectonic evolution of the northern Bristol Bay region, southwestern Alaska: Santa Cruz, University of California, unpub. Ph. D. thesis, $163 \mathrm{p}$.

Box, S. E., 1985b, Early Cretaceous orcrenic belt in northwestern Alaska: internal organization, lateral extent and tectonic inter?retation, in Howell, D. G., ed., Earth Science Series, v. 1, Circum-Pacific Council for Energy and Mineral Resources (in press).

Box, S. E., 1985c, Geologic setting of righ-pressure metamorphic rocks, Cape Newenham area, southwestern Alaska, in Bartsch-Winkler, Susan, ed., The United States Geological Survey in Alaska: Accomplishments during 1984: U.S. Geological Survey Circular 967, this volume. 
Dempsey, W. J., Meuschke, J. L., and Andreasen, G. E., 1957, Total intensity aeromagnetic profiles of Bethel Basin, Alaska: U.S. Geological Survey Open-File Report, 3 sheets, scale $1: 250,000$.

Globerman, B. R., Gill, J. B. and Batatian, Darlene, 1984, Petrochemical data from Upper Cretaceous volcanic rocks-Hagemeister, Crooked, and Summit Islands, SW Alaska (abs.): Geological Society of America Abstracts with Programs, v. 16, no. 5, p. 286.

Griscom, Andrew, 1978, Aeromagnetic interpretation of the Goodnews and Hagemeister Island quadrangles region, southwestern Alaska: U.S. Geological Survey Open-File Report 78-9-C, 20 p., scale $1: 250,000$.

Hoare, J. M., and Coonrad, W. L., 1959, Geologic map of the Bethel quadrangle, Alaska: U.S. Geological Survey Miscellaneous Geologic Investigations Map I-285, scale 1:250,000.

Hoare, J. M., and Coonrad, W. L., 1961a, Geologic map of the Hagemeister Island quadrangle, Alaska: U.S. Geological Survey Miscellaneous Geologic Investigations Map I-321, scale $1: 250,000$.

Hoare, J. M., and Coonrad, W. L., 1961b, Geologic map of the Goodnews quadrangle, Alaska: U.S. Geological Survey Miscellaneous Geologic Investigations Map I-339, scale 1:250,000.

Hoare, J. M., and Coonrad, W. L. 1978, Geologic map of the Goodnews and Hagemeister Island quadrangles region, southwestern Alaska: U.S. Geological Survey Open-File Report 78-9-B, scale $1: 250,000$.

Jones, D. L., Silberling, N. J., Berg, H. C., and Plafker, George, 1981, Tectonostratigraphic terrane map of Alaska: U.S. Geological Survey Open-File Report 81-792, scale $1: 2,500,000$.

Moll, E. J., and Patton, W. W., Jr., 1981, Preliminary report on the Late Cretaceous and early Tertiary volcanic and related plutonic rocks in western Alaska, in Coonrad, W. L., ed., The United States Geological Survey in Alaska: Accomplishments during 1980: U.S. Geological Survey Circular 844, p. 73-76.

Palmer, A. R., 1983, The Decade of North American Geology 1983 geologic time scale: Geology, v. 11 , no. 9, p. 503-504.

Turner, D. L., Forbes, R. B., Aleinikoff, J. N., McDougall, Ian, and Hedge, C. E., 1985, Geologic and geochronologic studies of the Early Proterozoic Kanektok metamorphic complex of southwestern Alaska: Canadian Journal of Earth Sciences (in press).

Reviewers: W. L. Coonrad and D. L. Jones

\section{GEOLOGIC SETTING OF \\ HIGH-PRESSURE METAMORPHIC ROCKS, \\ CAPE NEWENHAM AREA, \\ SOUTHWESTERN ALASKA}

\section{Stephen E. Box}

The occurrence of high-pressure mete morphic minerals (lawsonite, blue amphibole) in the Cape Newenham area of southwestern Alaska was reported earlier by Hoare and Coonrad (1978a). This report describes the geologic setting of these occurrences based, in part, on $1: 20,000$-scale shoreline mapping (Box, 1985a). The map area (fig. 29) includes parts of the Goodnews and Togiak terranes (Box, $1985 \mathrm{a} ; 1985 \mathrm{~b})$, and is divided into three structural units separated by low-angle faults (from bottom to top): (1) an unfoliated unit of calcareous sedimentary and basaltic rocks (Goodnews terrene, Platinum subterrane); (2) a foliated unit (Goodnews terrane, Cape Peirce subterrane); and (3) an unfoliated mafic igneous suite (basal part of the Hagemeister subterrane of the Togiak terrane).

The structurally highest unit (unit 3 ) is informally termed the dismembered Newenhar ophiolite, and its components are listed in table ?. Upper Triassic cherts within the basalt section (Box, 1985a) are tentatively interpreted to c'ate the igneous development of the entire ophiolite, although supporting geochronologic and geochemical data are not available. Prehnite-pumpellyite facies mineral assemblages are characteristic of these unfoliated rocks, but gabbros locally range into lower greenschist facies. The underlying fault surface variably places basalt, diabase, or $g$ bbro on the structurally underlying schist unit. West of Security Cove, a narrow, conspicuously crenulated greenschist facies mylonite zone occurs in gabbro along the basal contact. Blue amphiboles occur rarely in unfoliated basalt just above the contact east of Cape Peirce.

Structurally below the dismembered ophiolite are schistose metamorphic rocks (unit 2) which record predominantly greenschist- to pumpellyiteactinolite-facies metamorphism (facies terminology of Turner, 1981). Blue amphibole and lawsonite have been observed only in rocks of the Security Cove window (fig. 29), and their sporadic occurrence within typical greenschist-facies assemblages suggests that these rocks record transitionel greenschist-blueschist-facies metamorphism. Typical mineral assemblages are listed in table 10.

Low-angle faults divide unit 2 in the Security Cove window into three nappes with contrasting protoliths (fig. 29, table 10): an upper metabasaltic, a middle metaconglomerate, and a lower, calcareous metasedimentary-metabasaltic nappe. Serpentinized ultramafic rocks occur along the fault boundaries and locally include blocks of unfoliate gabbro and (or) trondhjemite. Only the upper nappe is exposed in the window around the Osviak Rive" mouth, 


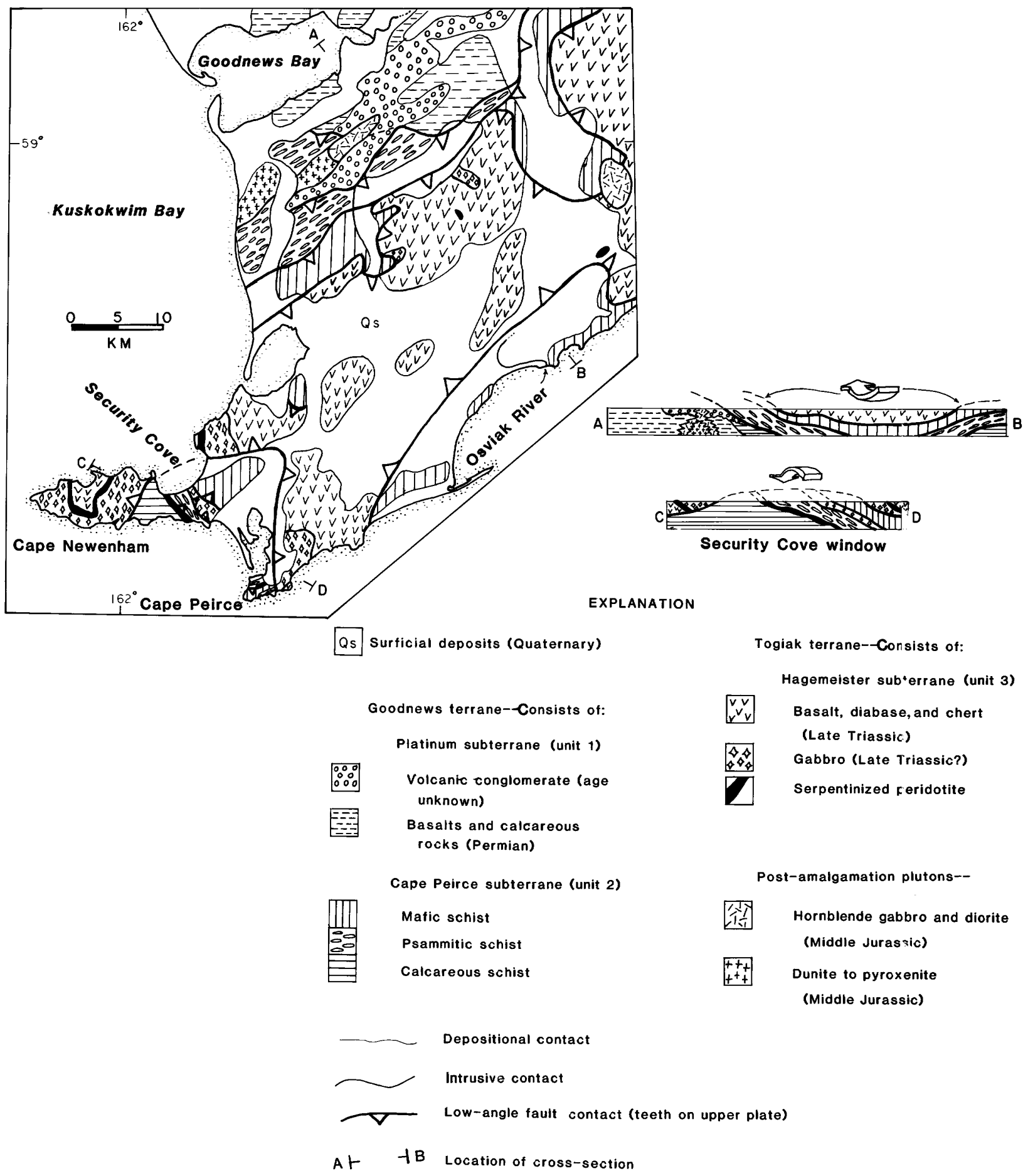

Figure 29.--Generalized geologic map and cross sections of the Cape Newenham region, southwestern Alaska (modified from Box, 1985a). High-pressure metamorphic minerals are known only from the Cape Peirce-Security Cove exposure of the Cape Peirce subternane. Arrows in cross sections indicate NNE-directed overthrusting inferred from figure 30a. Generalized geology based on 1:20,000 scale shoreline mapping and from unpublished field notes of J.M. Hoare and W.L. Coonrad (1952-53; 1974-76), and A.L. Clark and D.J. Grybeck (1971-72). 
and the upper and middle nappes crop out in the area south of Goodnews Bay.

Each of the three structural nappes of unit 2 records a synmetamorphic deformation $\left(D_{2}\right)$, a lateto post-metamorphic crenulation $\left(\mathrm{D}_{3}\right)$, and postmetamorphic open folding $\left(\mathrm{D}_{4}\right)$. The Security Cove and Osviak River windows are culminations along $\mathrm{D}_{4}$ anticlinoria. The lower and middle nappes record evidence of pre-metamorphic deformation $\left(D_{1}\right)$ of contrasting character (table 10). $\mathrm{D}_{2}$ synmetamorphic deformation apparently records the juxtaposition of the three nappes. Geometrical analysis of orientations of $\mathrm{D}_{2}$ mineral lineations and asymmetric fold axes (fig. $30 \mathrm{~A}$ ) suggests "top to the NNE" motion during $\mathrm{D}_{2} \cdot \mathrm{D}_{3}$ crenulation microfolds occur in conjugate pairs (fig. 30B) which, if interpreted as compressional features, suggest west- to northwest-directed compression.

Metamorphism of unit 2 is constrained to preMiddle Jurassic time by crosscutting, unfoliated
Middle Jurassic plutons (Hoare and Coonrad, 1978b; Box, 1985a). The lithologic similarity of the Upper Triassic(?) Newenham ophiolite to the protoliths of the subjacent upper nappe of unit 2 suggests the latter is the structurally transposed equivelent of the former. Metamorphism would therefore be constrained to a Late Triassic or Early Jurassic interval. A single Late Triassic $\mathrm{K}-\mathrm{Ar}$ amphitole age $(231.2+6.9$ m.y.) from schist in the Security Cove windo $\bar{W}$ supports this interpretation (W. K. W'allace, ARCO Alaska, oral commun., 1983). Two samples of schist from the Osviak River window gave $153+10$ m.y. K-Ar mica ages, probably representing a later

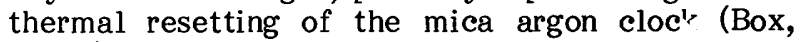
1985a).

The schistose rocks of unit 2 are faulted onto unfoliated rocks of unit 1 along a southeast-dipping fault south of Goodnews Bay (fig. 29). Unit 1 consists of pillow basalt, volcaniclastic strata, and locally fossiliferous calcareous strata of Permian age

Table 9.--Characteristics of the dismembered Newenham ophiolite (unit 3)

\begin{tabular}{|c|c|c|c|c|c|}
\hline Lithology & Description & Primary mineralogy & $\begin{array}{l}\text { Contact } \\
\text { relationships }\end{array}$ & $\begin{array}{l}\text { Secondary } \\
\text { mineralogy }\end{array}$ & Age const raints \\
\hline $\begin{array}{l}\text { Basaltic } \\
\text { breccia }\end{array}$ & $\begin{array}{l}\text { Angular, vesic- } \\
\text { ular breccias, } \\
\text { pillow brec- } \\
\text { cias, hyalo- } \\
\text { clastite }\end{array}$ & $\begin{array}{l}\text { Plagioclase-clinopyroxene } \\
\text { porphyry with groundmass } \\
\text { opaque minerals } \\
\text { Common glass shards } \\
\text { highly amygdaloidal }\end{array}$ & $\begin{array}{l}\text { Stratigraphically } \\
\text { overlies basalt } \\
\text { and chert sequence }\end{array}$ & $\begin{array}{l}\text { Prehnite- } \\
\text { pumpellyite } \\
\text { facies }\end{array}$ & $\begin{array}{l}\text { Intruded by } 186 \mathrm{~m} . \mathrm{y} . \\
\text { plutons, strsti- } \\
\text { graphically above } \\
\text { Upper Triassic chert }\end{array}$ \\
\hline Chert & $\begin{array}{l}\text { Both inter- } \\
\text { pillow and } \\
\text { bedded, red } \\
\text { and white } \\
\text { radiolarian } \\
\text { chert }\end{array}$ & $\begin{array}{l}\text { Radiolarian tests } \\
\text { Quartz } \\
\text { Hematite }\end{array}$ & $\begin{array}{l}\text { Interpillow pods } \\
\text { in basalt, bedded } \\
\text { sections above } \\
\text { basalt, locally } \\
\text { overlain by pil- } \\
\text { low basalt and } \\
\text { cut by diabasic } \\
\text { sills }\end{array}$ & Quartz-pyrite & $\begin{array}{l}\text { Late Triassi? radio- } \\
\text { larians in bidded } \\
\text { chert }\end{array}$ \\
\hline Basalt & $\begin{array}{l}\text { Mostly pil- } \\
\text { lowed, some } \\
\text { massive } \\
\text { interbedded } \\
\text { hyaloclas- } \\
\text { tite }\end{array}$ & $\begin{array}{l}\text { Plagioclase-clinopyroxene } \\
\text { porphyry with groundmass } \\
\text { opaque minerals } \\
\text { Highly amygdaloidal }\end{array}$ & $\begin{array}{l}\text { Intruded by dia- } \\
\text { base sills, } \\
\text { locally faulted } \\
\text { over schists }\end{array}$ & $\begin{array}{l}\text { Prehnite- } \\
\text { pumpellyite } \\
\text { facies }\end{array}$ & $\begin{array}{l}\text { Depositionally(?) } \\
\text { interbedded with } \\
\text { Upper Triassic } \\
\text { cherts }\end{array}$ \\
\hline Diabase & $\begin{array}{l}\text { Dikes, sills } \\
\text { and more mas- } \\
\text { sive bodies }\end{array}$ & $\begin{array}{l}\text { Plagioclase + clinopyroxene } \\
\pm \text { olivine }\end{array}$ & $\begin{array}{l}\text { Sills in basalt- } \\
\text { chert sequence } \\
\text { Dikes cutting } \\
\text { gabbro } \\
\text { Locally faulted } \\
\text { over schists }\end{array}$ & $\begin{array}{l}\text { Prehnite- } \\
\text { pumpellyite } \\
\text { to low } \\
\text { greenschist } \\
\text { facies }\end{array}$ & $\begin{array}{l}\text { Intruded by } 186 \mathrm{~m} . \mathrm{y} \text {. } \\
\text { pluton }\end{array}$ \\
\hline Trondhjemite & $\begin{array}{l}\text { Massive, partly } \\
\text { recrystallized }\end{array}$ & $\begin{array}{l}\text { Plagioclase + quartz } \\
5 \text { percent mafic } \\
\text { minerals }\end{array}$ & $\begin{array}{l}\text { Fault block mark- } \\
\text { ing fault be- } \\
\text { tween two } \\
\text { schistose units }\end{array}$ & $\begin{array}{l}\text { Transitional } \\
\text { greenschist- } \\
\text { blueschist- } \\
\text { facies }\end{array}$ & Unknown \\
\hline Gabbro & $\begin{array}{l}\text { Mostly massive, } \\
\text { complex poly- } \\
\text { intrusive } \\
\text { Locally pegma- } \\
\text { titic } \\
\text { Layering rare }\end{array}$ & $\begin{array}{l}\text { Plagioclase }+ \text { clinopyroxene } \\
\text { Minor olivine }+ \text { or thopyroxene }\end{array}$ & $\begin{array}{l}\text { Faulted over } \\
\text { schists, locally } \\
\text { over diabase; } \\
\text { locally as } \\
\text { blocks along } \\
\text { faults separat- } \\
\text { ing schistose } \\
\text { units, cut by } \\
\text { rare mylonite } \\
\text { zones }\end{array}$ & $\begin{array}{l}\text { Low green- } \\
\text { schist } \\
\text { facies }\end{array}$ & Unknown \\
\hline Peridotite & $\begin{array}{l}\text { Mostly massive } \\
\text { Highly serpen- } \\
\text { tinized }\end{array}$ & $\begin{array}{l}\text { Dunite to harzburgite } \\
\text { Olivine }+ \text { orthopyroxene } \\
+ \text { spinel }+ \text { clinopyroxene }\end{array}$ & $\begin{array}{l}\text { As blocks in } \\
\text { slickensided } \\
\text { serpentinite } \\
\text { marking fault } \\
\text { zones }\end{array}$ & $\begin{array}{l}\text { Replaced by } \\
\text { serpentine } \\
\text { minerals }\end{array}$ & Unknown \\
\hline
\end{tabular}


Table 10.--Characteristics of schistose nappe units of Cape Peirce subterrane (unit 2)

\begin{tabular}{|c|c|c|c|c|c|c|}
\hline $\begin{array}{l}\text { NAPPE } \\
\text { UNIT }\end{array}$ & PROTOLITHS & $\begin{array}{l}\text { D2 MAFIC-M ETAMORPHIC } \\
\text { MINERAL ASSEMBLAGE }\end{array}$ & D1 & $\begin{array}{l}\text { STRUCTURAL FEATURES } \\
\text { D2 }\end{array}$ & D3 & D4 \\
\hline Upper & $\begin{array}{l}\text { Pillow basalt } \\
\text { Basalt breccia } \\
\text { Mafic tuffs } \\
\text { Chert } \\
\text { Diabase } \\
\text { Gabbro }\end{array}$ & $\begin{array}{l}\text { Plagioclase } \\
\text { Epidote } \\
\text { Chlorite } \\
\text { Actinolite } \\
\text { Sphene } \\
+ \text { Glaucophane } \\
\pm \text { Lawsonite } \\
\pm \text { Pumpellyite }\end{array}$ & Not present & $\begin{array}{l}\text { Flattening + mineral } \\
\text { foliation, } \\
\text { Amphibole + plagioclase } \\
\text { lineation, } \\
\text { Local mylonitization, } \\
\text { No recognized folding }\end{array}$ & $\begin{array}{l}\text { Sporadic } \\
\text { conjugate } \\
\text { crenulation } \\
\text { cleavage } \\
\text { (W to NW- } \\
\text { directed } \\
\text { horizontal } \\
\text { stress) }\end{array}$ & $\begin{array}{l}\text { Northeast-trending } \\
\text { open folds with } \\
\text { subhorizontal axes }\end{array}$ \\
\hline Middle & $\begin{array}{l}\text { Conglomerate } \\
\text { Sandstone } \\
\text { Shale } \\
\text { (Andesite plus } \\
\text { minor ultra- } \\
\text { mafite source) }\end{array}$ & Same as above & $\begin{array}{l}\text { Isoclinal } \\
\text { folding, } \\
\text { Distension } \\
\text { of fold } \\
\text { limbs, } \\
\text { No cleav- } \\
\text { age }\end{array}$ & $\begin{array}{l}\text { Non-coaxial tight } \\
\text { refolding; flatten- } \\
\text { ing, and mineral } \\
\text { foliation; amphi- } \\
\text { bole and plagio- } \\
\text { clase lineation; } \\
\text { cobble elongation } \\
\text { lineation }\end{array}$ & $\begin{array}{l}\text { Local crenu- } \\
\text { lation } \\
\text { cleavage } \\
\text { (2 sets) }\end{array}$ & Same as above \\
\hline Lower & $\begin{array}{l}\text { Calcareous } \\
\text { sandstones } \\
\text { Calcareous } \\
\text { conglomerate } \\
\text { Limestone } \\
\text { Basalt } \\
\text { Basaltic } \\
\text { conglomerate }\end{array}$ & $\begin{array}{l}\text { Same as above } \\
\text { (no lawsonite } \\
\text { reported) }\end{array}$ & $\begin{array}{l}\text { Tight fold- } \\
\text { ing with } \\
\text { axial } \\
\text { planar } \\
\text { slaty } \\
\text { cleavage }\end{array}$ & $\begin{array}{l}\text { Non-coaxial tight } \\
\text { refolding } \\
\text { (type } 2 \text { interference } \\
\text { fold patterns) } \\
\text { Weak to strong mineral } \\
\text { foliation } \\
\text { Amphibole + plagioclase } \\
\text { lineation }\end{array}$ & $\begin{array}{l}\text { Local crenu- } \\
\text { lation } \\
\text { cleavage } \\
\text { (1 or } 2 \text { sets) }\end{array}$ & Same as above \\
\hline
\end{tabular}


(Hoare and Coonrad, 1978b), some of which were deposited in a shallow marine environment. Undated volcanic conglomerates occur in the southeastern part of the unit 2 exposure area. Unit 2 has been subjected only to prehnite-pumpellyite facies metamorphism. Middle Jurassic gabbroic to peridotitic intrusions cut across the contact between units 1 and 2 (fig. 29).

Unit 1 may be correlative with protoliths of schists from the lower and middle nappes of the Cape Peirce subterrane. The volcanic conglomerate of unit 1, derived from vesicular porphyritic andesite sources (probably the Togiak terrane), is similar to protoliths of the middle metaconglomeratic nappe of unit 2. The interbedded calcareous sedimentary and basaltic rocks of unit 1 resemble the protoliths of the lowest nappe of unit 2. It is tentatively inferred that the lower and middle nappes of unit 2 are structurally transposed equivalents of unit 1. However, detailed geochemical correlation and geochronologic work are required to substantiate this.

In summary, the foliated, high-pressure metamorphic rocks near Cape Newenham (unit 2) appear to be derived from the protoliths of the structurally overlying (unit 3 ) and structurally underlying (unit 1) terranes. Metamorphism and terrane juxtaposition occurred in Late Triassic or Early Jurassic time. Juxtaposition was accomplished by north-northeastward overthrusting of unit 3 over unit 2. Basal unit 3 (Hagemeister subterrane) is interpreted as the base of an intraoceanic volcanic arc, while unit 1 (Platinum subterrane) is interpreted to represent an unspecified type of oceanic plateau. Development of metamorphic unit 2 (Cape Peirce subterrane) occurred during collision and partial subduction of the oceanic plateau beneath the volcanic arc.

One puzzling relationship should be noted. The abrupt metamorphic grade contrast between basal unit 3 and structurally underlying unit 2 (i.e., prehnite-pumpellyite over transitional greenschistblueschist facies) implies removal of several kilometers of the originally intervening rock column. This suggests that this fault is actually a low-angle normal fault (i.e., shallow over deeper crustal rocks) and not a compressional thrust fault. $\mathrm{D}_{3}$ crenulation microfolds (fig. 30B), which are most common in unit 2 near the upper fault contact, might actually be extensional crenulations (Platt and Vissers, 1980) indicating E-W to SE-NW extension. In this interpretation early NNE-directed overthrusting was followed by WNW-ESE detachment faulting. A similar case of extensional reactivation of an original compressional fault has recently been documented by Rhodes and Hyndman (1984). Further detailed fabric studies along the boundary of units 2 and 3 are necessary to elucidate its kinematic history. The postulated extensional deformation may have relevance to the rapid uplift required for preservation of high-pressure mineral assemblages (Lister and others, 1984).

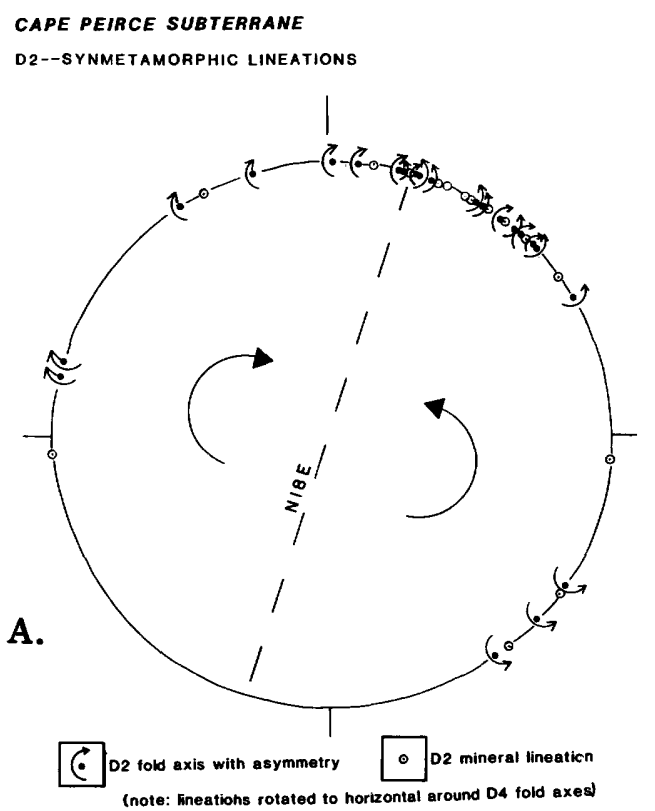

CAPE PEIRCE SUBTERRANE D3--CAENULATION CLEAVAGE

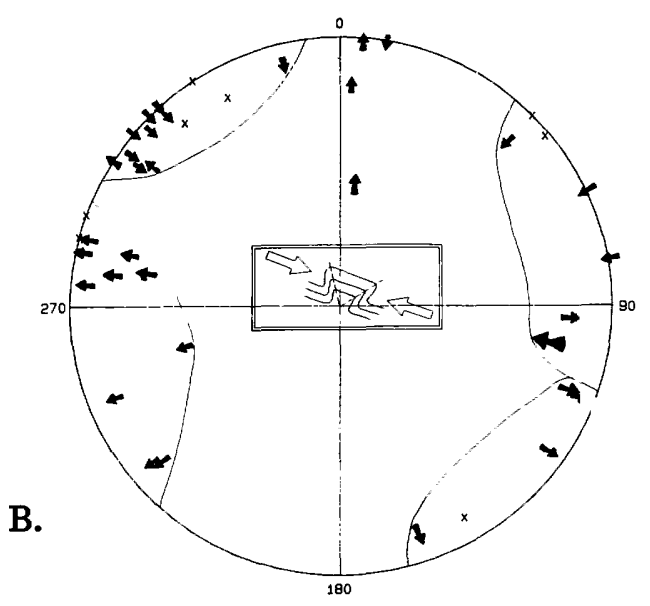

Figure 30.--Equal area stereonet plots of structural data from schistose rocks of the Cape Peirce subterrane (unit 2) of the Goodnews terrane. (A), $D_{2}$ lineations from Cape Peirce-Security Cove window. Separation of fold axes of opposite asymmetries across N. $18^{\circ}$ E. line suggests rotation of fold axes into transport direction during overthrusting. (B), Poles to $\mathrm{D}_{3}$ crenulation cleavage from Osviak River window, witr arrows indicating vergence direction of crenulation microfolds. Inset illustrates conjugate reletionship and inferred compressive stress direction. 


\section{REFERENCES CITED}

Box, S. E., 1985a, Mesozoic tectonic evolution of the northern Bristol Bay region, southwestern Alaska: Santa Cruz, University of California, Ph. D. thesis, $163 \mathrm{p}$.

Box, S. E., 1985b, Terrane analysis of the northern Bristol Bay region, southwestern Alaska; in Bartsch-Winkler, Susan, ed., The United States Geological Survey in Alaska-Accomplishments during 1984: U.S. Geological Survey Circular 967 (this volume).

Hoare, J. M., and Coonrad, W. L., 1978a, Lawsonite in southwestern Alaska; in Johnson, K. M., ed., The U.S. Geological Survey in Alaska-Accomplishments during 1977: U.S. Geological Survey Circular 772-B, p. 55-57.

Hoare, J. M., and Coonrad, W. L., 1978b, Geologic map of the Goodnews and Hagemeister Island quadrangles region: U.S. Geological Survey Open-File Report 78-9-B, scale 1:250,000.

Lister, G. S., Banga, Greetje, and Feenstra, Anne, 1984, Metamorphic core complexes of Cordilleran type in the Cyclades, Aegean Sea, Greece: Geology, v. 12, no. 4, p. 221-225.

Platt, J. P., and Vissers, R. L. M., 1980, Extensional structures in anisotropic rocks: Journal of Structural Geology, v. 2, no. 4, p. 397-410.

Rhodes, B. P., and Hyndman, D. W., 1984, Kinematics of mylonites in the Priest River "metamorphic core complex", northern Idaho and northeastern Washington: Canadian Journal of Earth Sciences, v. 21, no. 11, p. 1161-1170.

Turner, F. J., 1981, Metamorphic petrology: mineralogical, field and tectonic aspects: New York, McGraw-Hill, 524 p.

Reviewers: M. C. Blake, Jr., and W. L. Coonrad

\section{LATE QUATERNARY GLACIATION OF THE PAVLOF BAY AND PORT MOLLER AREAS, ALASKA PENINSULA}

\section{Florence R. Weber}

The surficial geology map of Alaska (Karlstrom and others, 1964), based on work completed in 1960, shows the location of numerous glacial moraines on the Alaska Peninsula. Since then, the following mapping programs have subdivided and delineated these features in greater detail: Detterman and Reed (1973) in the Iliamna quadrangle, Detterman and others (1981) in the Chignik and Sutwik Island quadrangles, and Funk (1973) in the Cold Bay area. Investigations are currently in progress in several other areas on the Peninsula. The following is a preliminary report on results of one of these studies accomplished as a part of a mineral resources assessment of the Port Moller and Stepovak Bay quadrangles centered in the Pavlof Bay and Port Moller area (fig. 31).
Three major stades of probable lete Wisconsin age are recognized in the area (fig. 31 ). These advances formed giant arcuate terminal moraines as much as $95 \mathrm{~km}$ long at the head of Pavlof Bay; they connect the main Alaska Peninsula to what was once an island in the vicinity of Pavlof Volcano and Mt. Dutton. A similar, but somewhat smaller, morainal are at the head of Cold Bay connects the Peninsula with another island formed by Frosty Peak Volcano. In short, Pleistocene glaciation was a major factor in building the southwestern end of the Alaskan Peninsula from a series of volernic islands.

Both Cold Bay and Pavlov Bay were the axes of major glacial troughs. Positioning of the terminal moraines clearly indicates that much of the glacial mass forming them moved from the south and southwest, originating on the continental shelf and present-day islands in the Pacific Orean. Port Moller and Herendeen Bay, on the Berin? Sea side of the Peninsula, are also glacial troughs. Remnants of moraines encircle these bays also but are broken and submerged under the Bering Sea at the bay mouths. Port Moller and Herende?n terminal moraines, and those on the northwest side of the Peninsula between Cold Bay and Pavlof Bay and between Port Moller and Veniaminof Volcano, are of lesser extent than those at Cold and Pavlof Bays and may have originated along the present crest of the Peninsula.

Three large terminal moraines lonated at the head of Pavlof Bay exhibit essentially the same physical appearance and composition. The oldest is divided into two parts on the northwest side, but coalesces to form a single moraine on the northeast. Nearly all have peculiarly subdued form when compared to moraines of similar age and extent seen elsewhere in Alaska; this may result from their deposition in a marine environment and their subsequent erosion/truncation by sea-level changes. Stream-cut exposures through these moraines show the drift, for the most part, to be well stratified, a characteristic of subaqueous deposition.

Bedrock areas of the Peninsula ere dissected by anastomosing glaciated valleys (not shown on the map). Between Mt. Dutton and Pavlof Volcano and between Mt. Dana and Veniaminof Volerno, the sedimentary rocks that composed bedrock, reinforced by the volcanic edifices, apparently blocked glacial advance to the northwest from the continental shelf. Part of the time, locally derived glaciers, originating in the ice cap formed on these mountains, furnished material for the lesser moraines mentioned above.

Few radiocarbon dates have be?n obtained, due to a paucity of both good exposure with available material and time to search for them, so agedating of the glacial episodes is problematical. The Port Moller moraines on the north sid: of the bay have been dated by Detterman and others (1981). The oldest opposing late Wisconsin moraine on the south side of the bay merges with the oldest of the three at the head of Pavlof Bay. Thus, the suite of 


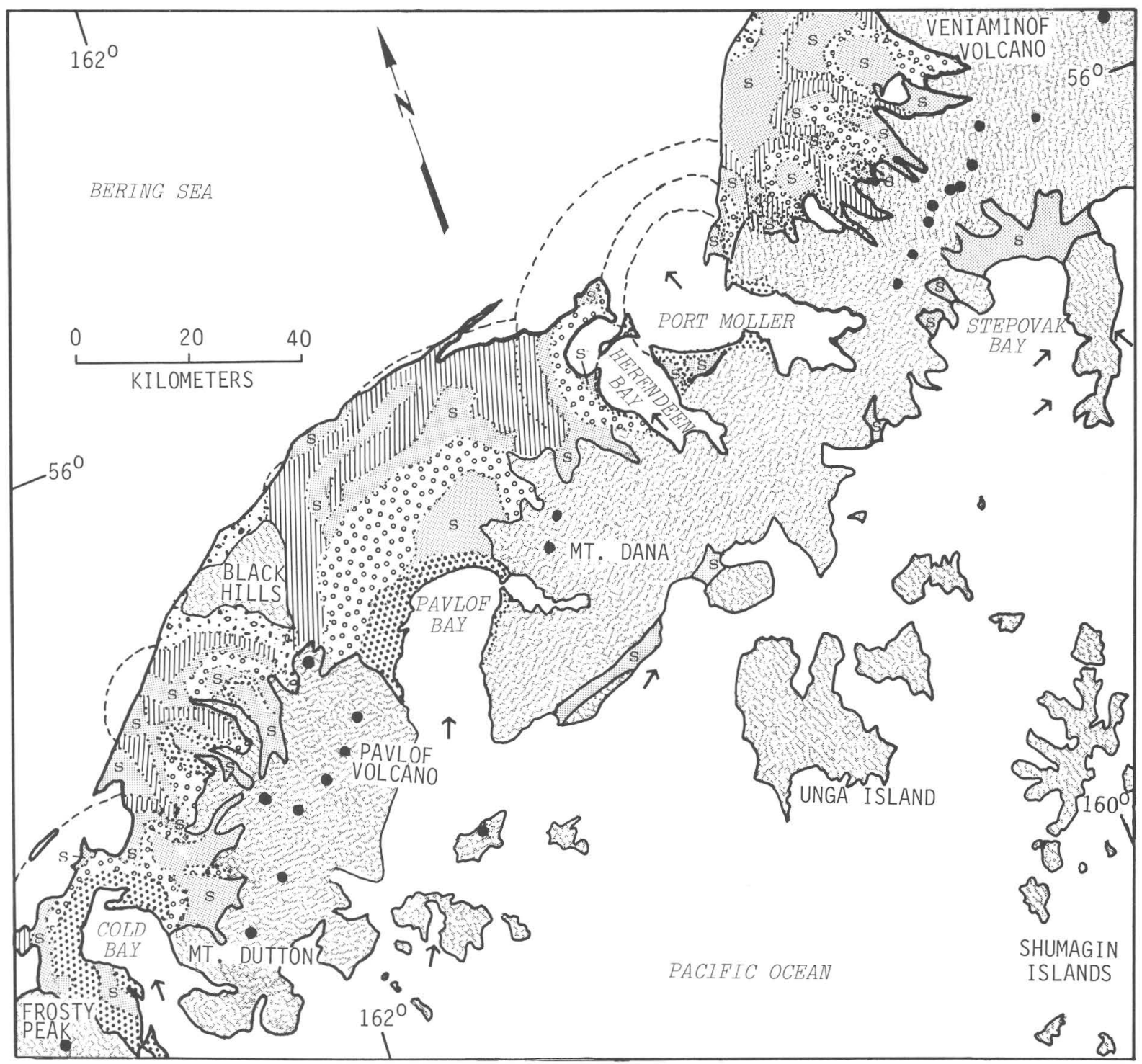

EXPLANATION

Brooks Lake glaciation of Muller (1953)

........ Drift of Newhalen stade

$\because \because \because$ Drift of Iliamna stade

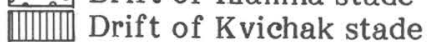

Mak Hill glaciation of Muller (1953)

$\because \because$ Drift

s. Surficial deposits, undivided

Bedrock

$\nwarrow$ Direction of ice movement

- Volcanic centers

Figure 31.--Extent and possible correlation of glacial moraines in the Pavlof Bay-Port Moller area. Deposits in the mountain valleys and on the Pacific Ocean islands are not shown. 
Pavlof moraines probably represents oldest to youngest drift of the Kvichak, Iliamna, and Newhalen stades of the Brooks Lake glaciation of Muller (1953), as it does at Port Moller.

Because of differences in size and source areas, the Port Moller and Pavlof Bay moraines do not necessarily have the same clast content, although the general topographic expression is similar in relief, sharpness of crest, abundance of pothole lakes, erosional dissection, and other characteristics. Exotic fragments of petrified wood, derived possibly from Tertiary continental shelf deposits, are found in Pavlof and Cold Bay moraines (Funk, 1973), whereas local material, such as fragments of Mesozoic fossil coquina and distinctive intrusive igneous rock types found in the bedrock at the head of Port Moller, are present in the Port Moller moraines. Andesitic volcanic rocks constitute the major clast type in all moraines.

The age of glacial deposits southwest of the Pavlof moraines is even more problematical and is based entirely on photointerpretation; i.e., on the appearance and succession of advances. Relative ages of these deposits could be misidentified by as much as a stade. The Cold Bay area is tentatively reinterpreted by the use of Landsat and infra-red photography unavaiable to Funk in 1973.

Remnants of older till on the Bering Sea coast have significantly different physical appearance when compared to the three major Pavlof Bay moraines of late Wisconsin age. Highly modified knob-andkettle topography (noticeably more weathered and subdued and supporting very few or no kettle ponds) is present. These remnants lie north and west of, or are overlapped by, deposits of the Brooks Lake glacial advances and possibly represent the Mak Hill Glaciation of Muller (1953) of inferred early Wisconsin age north of Port Moller, as described by Detterman and others (1981).

Glacial deposits in cirques, and small patches of relatively fresh-appearing drift, can be found in the large U-shaped valleys formed in the mountain ranges making up the backbone of the Peninsula. Deposits of two glacial episodes can be seen; they are either contemporaneous with some of the youngest of the Brooks Lake stades, or they represent Holocene (post-10,000 yr B.P.) events.

Glacial deposits and glacially carved forms are ubiquitous on the islands on the Pacific Ocean side of the Peninsula, but few of the deposits have been dated or correlated to known glaciations. Continuing investigation will undoubtedly reveal complex relations between various glaciations, volcanic eruptions, and sea-level changes.

\section{REFERENCES CITED}

Detterman, R. L., Miller, T. P., Yount, M. E., and Wilson, F. H., 1981, Quaternary geologic map of the Chignik and Sutwik Island quadrangles, Alaska: U.S. Geological Survey Miscellaneous
Investigations Series, Map I-1292, scale $1: 250,000,1$ sheet.

Detterman, R. L., and Reed, B. L., 1973 (1974), Surficial deposits of the Iliamna quadrangle, Alaska: U.S. Geological Survey Bulletin 1368A, p. A1-A64.

Funk, J. M., 1973, Late Quaternary geology of Cold Bay, Alaska, and vicinity: Storrs, University of Connecticut, unpub. M.S. thesis, 45 p.

Karlstrom, T. N. V., and others (comp.), 1964, Surficial geology of Alaska: U.S. Geological Survey Miscellaneous Geologic Investigations Map I-357, 2 sheets, scale 1:1,584,000.

Muller, E. H., 1953, Northern Alaska Peninsula and eastern Kilbuck Mountains; in Multiple glaciation in Alaska: U.S. Geological Survey Circular 289 , p. 2-3.

Reviewers: T. D. Hamilton and D. M. Hopkins

SOUTHERN ALASKA

(Figure 32 shows study areas described.)

\section{AGE OF \\ DEVONIAN IGNEOUS-ARC TERRANES IN THE NORTHERN MOUNT HAYES QUADRANGLE, EASTERN ALASKA RANGE}

\section{John N. Aleinikoff and Warren J. Nokleberg}

Northern Mount Hayes quadrangle, north of the Mount Gakona fault, is composed, from north to south, of the Lake George, Macomb, and Jarvis Creek Glacier tectonostratigraphic terranes (Nokleberg and others, 1983; Nokleberg and Aleinikoff, 1985) which occur in the southern part of the Yukon-Tanana terrane (Jones and others, 1981). To the south, the Hayes Glacier terrane occurs between the Mount Gakona and Denali faults and includes the Pingston terrane of Jones and others $(1981)$ and Nokleberg and others $(1983 ; 1984$; fig. 46, this volume). Metasedimentary, metavolcanic, and metaplutonic rocks of these four terranes are, in most areas, twice deformed and metamorphosed, first at amphibolite facies and later at greenschist facies (Nokleberg and Aleinikoff, 1985). Generally, terranes to the north are higher grade than those to the south (Nokleberg and Aleinikoff, 1985); locally extensive granitic plutons of Cretaceous and early Tertiary age intrude the Lake George, Macomb, Jarvis Creek Glacier, and Hayes Glacier terranes. This study summarizes $\mathrm{U}-\mathrm{Pb}$ dating conducted on seven metavolcanic and four metaplutonic samples from the four terranes, and summarizes and revises earlier isotopic studies (Aleinikoff, 1984; Aleinikoff and Nokleberg, 1984a, b, 1985).

The Lake George terrane consists of a sequence of coarse-grained, multiply deformed, mylonitic pelitic schists that are intruded by augen gneiss and schistose granodiorite. The Macomb ter- 


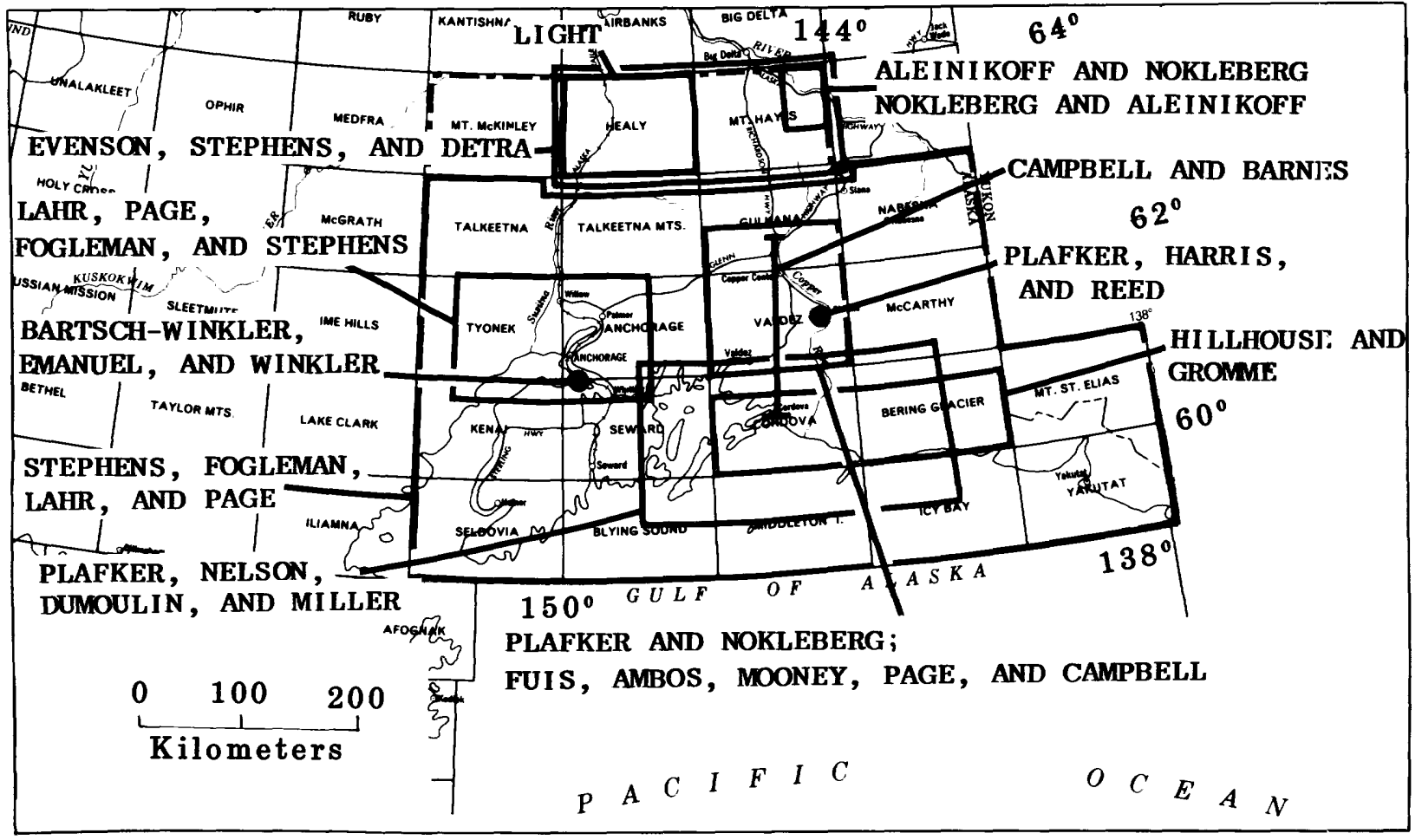

Figure 32.--Map showing areas in southern Alaska discussed in this circular.

rane consists of a sequence of fine- to mediumgrained mylonitic schists that are derived from fine-grained clastic and calcareous sedimentary rocks. The metasedimentary schists are intruded by schistose quartz monzonite to quartz diorite. The Jarvis Creek Glacier terrane consists of metavolcanic and metasedimentary mylonitic schists and local phyllonite. Metavolcanic schists are derived mainly from andesite, quartz keratophyre, and lesser dacite and basalt; metasedimentary schists are derived from varying amounts of fine-grained clastic, calcareous, and volcanogenic sediments. The Hayes Glacier terrane consists of metasedimentary and metavolcanic phyllonites, in part derived from many of the same protoliths as rocks in the Jarvis Creek Glacier terrane. However, as discussed by Nokleberg and Aleinikoff (1985), the Hayes Glacier terrane differs from the Jarvis Creek Glacier terrane in having different proportions of lithologies, a lower metamorphic grade, and more intense deformation.

In the northeastern part of the Mount Hayes quadrangle, Devonian ages have been obtained for metaigneous rocks in the Lake George, Macomb, Jarvis Creek Glacier, and Hayes Glacier terranes. $\mathrm{U}-\mathrm{Pb}$ data from seven size fractions of zircons from a metamorphosed schistose granodiorite in the Lake George terrane yield an age of about 360 m.y. (Devonian) (Aleinikoff and Nokleberg, 1985). This age is about $20 \mathrm{~m} . \mathrm{y}$. older than batholitic intrusions which are protoliths of augen gneiss to the north (Aleinikoff, 1984; Dusel-Bacon and Aleinikoff, 1985; Aleinikoff and Nokleberg, 1985).

Results from U-Pb dating of two metaplutonic samples from the Macomb terrane and six metavolcanic samples from the Jarvis Creek Glacior and Hayes Glacier terranes in the northeastern part of the Mount Hayes quadrangle yield scatteref data (fig. $33 \mathrm{~A}$, table 11) with ${ }^{207} \mathrm{~Pb} /{ }^{206} \mathrm{~Pb}$ ages ranging from 363 to $1023 \mathrm{~m} . \mathrm{y}$. Evidence of inherited lead from an approximately $2.0-2.3-\mathrm{m} . \mathrm{y}$.-old source is documented in the Yukon-Tanana Upland (Aleinikoff and others, 1981; this study). However, the degree of inheritance decreases markedly with a decreasing zircon grain size (table 11). In six of the eight samples, the finest size fractions have ${ }^{207} \mathrm{~Pb} /{ }^{206} \mathrm{~Pb}$ ages near $370 \mathrm{~m} . \mathrm{y}$.; none of the fractions have a ${ }^{207} \mathrm{~Pb} /{ }^{206} \mathrm{~Pb}$ age of less than $3 \in 3$ m.y. Thus, a best-fit line was calculated through the ten fine-grained fractions from these six samples and has intercept ages of $10+38$ and $372+8 \mathrm{~m} . \mathrm{y}$. (fig. $33 \mathrm{~A})$. This upper intercep $\bar{t}$ age is analytically identical to that determined for three zircon size fractions from a metavolcanic sample from the Hayes Glacier terrane in the northwestern part of the Mount Hayes quadrangle which yield an age of $373+$ 7 m.y. (sample 80AAF039A; Aleinikof:" and Nokleberg, 1984b). These are the only data from an individual sample from the Macomb, Jarvis Creek 
Glacier, or Hayes Glacier terranes that fall along a linear array (fig. 33A; fig. 46, Aleinikoff and Nokleberg, 1984a). Data from other samples are scattered.

We interpret these isotopic data to indicate a Devonian age for the metaigneous rocks in the Macomb, Jarvis Creek Glacier, and Hayes Glacier terranes in the northeastern part of the Mount Hayes quadrangle, but realize the inherent uncertainty of grouping rocks from different terranes for age determination. However, this interpretation is consistent with independently determined ages discussed below for the Lake George, Hayes Glacier, and Jarvis Creek Glacier terranes.

In contrast to the above ages, a previous study (Aleinikoff and Nokleberg, 1984a) con?luded that a metavolcanic sample (81ANK233A) frcm the Jarvis Creek Glacier terrane in the northwestern part of the Mount Hayes quadrangle was approximately 2.0 b.y. old (Early Proterozoic). Because this age is controversial, an additional sample (82ANK031 A) was collected on strike about $0.5 \mathrm{~km}$ east on the

Table 11.--Uranium-lead isotopic data for metaigneous rocks in the Macomb, Jarvis Creek Glacier, and Hayes Glacier terranes, northeastern Mount Hayes quadrangle, eastern Alaska Range

\begin{tabular}{|c|c|c|c|c|c|c|}
\hline \multirow[t]{2}{*}{ SAMPLE NUMBER } & \multirow[t]{2}{*}{ FRACTION } & \multirow[t]{2}{*}{$\mathrm{U}(\mathrm{ppm})$} & \multirow[t]{2}{*}{$\mathrm{Pb}(\mathrm{ppm})$} & \multicolumn{3}{|c|}{ AGES (m.y.*) } \\
\hline & & & & ${ }^{206} \mathrm{~Pb} /{ }^{238} \mathrm{U}$ & ${ }^{207} \mathrm{~Pb} /{ }^{235} \mathrm{U}$ & ${ }^{207} \mathrm{~Pb} / 206 \mathrm{~Pb}$ \\
\hline & \multicolumn{6}{|c|}{ Macomb terrane } \\
\hline 81ANK136B & $\begin{array}{l}+150 \\
-150+200 \\
-200+250 \\
-325\end{array}$ & $\begin{array}{l}547 \\
517 \\
524 \\
611\end{array}$ & $\begin{array}{l}33.4 \\
35.9 \\
33.7 \\
37.6\end{array}$ & $\begin{array}{l}312 \\
332 \\
334 \\
298\end{array}$ & $\begin{array}{l}343 \\
345 \\
343 \\
307\end{array}$ & $\begin{array}{l}565 \\
431 \\
407 \\
375\end{array}$ \\
\hline \multirow[t]{2}{*}{81 ANK $234 \mathrm{~A}$} & $\begin{array}{l}+150 \mathrm{NM}^{*} \\
-250+325 \mathrm{NM} \\
-325 \mathrm{NM}\end{array}$ & $\begin{array}{l}486 \\
612 \\
653\end{array}$ & $\begin{array}{l}29.6 \\
35.3 \\
37.5\end{array}$ & $\begin{array}{l}356 \\
338 \\
335\end{array}$ & $\begin{array}{l}362 \\
343 \\
34 \mathrm{C}\end{array}$ & $\begin{array}{l}396 \\
375 \\
370\end{array}$ \\
\hline & \multicolumn{6}{|c|}{ Jarvis Creek Glacier terrane } \\
\hline $80 \mathrm{AAF} 040 \mathrm{~A}$ & $\begin{array}{l}+250 \\
-250\end{array}$ & $\begin{array}{r}1,130 \\
518\end{array}$ & $\begin{array}{l}58.6 \\
38.4\end{array}$ & $\begin{array}{l}253 \\
301\end{array}$ & $\begin{array}{l}276 \\
314\end{array}$ & $\begin{array}{l}477 \\
416\end{array}$ \\
\hline $80 \mathrm{AAF} 030 \mathrm{~B}$ & $\begin{array}{l}+100 \mathrm{NM} \\
-100+150 \mathrm{NM} \\
-200+250 \\
-250+325 \\
-325\end{array}$ & $\begin{array}{l}1,003 \\
1,151 \\
1,316 \\
1,329 \\
1,302\end{array}$ & $\begin{array}{l}66.3 \\
65.0 \\
61.5 \\
59.8 \\
54.6\end{array}$ & $\begin{array}{l}333 \\
278 \\
251 \\
248 \\
234\end{array}$ & $\begin{array}{l}436 \\
340 \\
269 \\
262 \\
246\end{array}$ & $\begin{array}{r}1,023 \\
791 \\
429 \\
388 \\
363\end{array}$ \\
\hline 81 ANK233A & $\begin{array}{l}+100 \text { Red } \\
-100+150 \text { Red } \\
-150+200 \text { Red } \\
-100+150 \text { Gray } \\
-325 \text { NM }\end{array}$ & $\begin{array}{r}354 \\
492 \\
422 \\
2,012 \\
466\end{array}$ & $\begin{array}{l}113 \\
137 \\
112 \\
156 \\
115\end{array}$ & $\begin{array}{r}1,536 \\
1,367 \\
1,383 \\
424 \\
1,256\end{array}$ & $\begin{array}{r}1,732 \\
1,636 \\
1,645 \\
652 \\
1,547\end{array}$ & $\begin{array}{l}1,978 \\
2,002 \\
1,999 \\
1,545 \\
1,971\end{array}$ \\
\hline 81ANK235A & $\begin{array}{l}-250+325 \\
-325\end{array}$ & $\begin{array}{l}552 \\
466\end{array}$ & $\begin{array}{l}58.2 \\
45.8\end{array}$ & $\begin{array}{l}335 \\
332\end{array}$ & $\begin{array}{l}343 \\
337\end{array}$ & $\begin{array}{l}400 \\
375\end{array}$ \\
\hline \multirow[t]{2}{*}{ 81 ANK031A } & $\begin{array}{l}+150 \mathrm{NM} \\
-250+325 \mathrm{NM} \\
-325 \mathrm{NM}\end{array}$ & $\begin{array}{l}322 \\
351 \\
378\end{array}$ & $\begin{array}{l}35.8 \\
24.8 \\
25.3\end{array}$ & $\begin{array}{l}589 \\
396 \\
384\end{array}$ & $\begin{array}{l}790 \\
443 \\
407\end{array}$ & $\begin{array}{r}1,409 \\
692 \\
539\end{array}$ \\
\hline & \multicolumn{6}{|c|}{ Hayes Glacier terrane } \\
\hline 82ANK046A & $\begin{array}{l}+200 \\
-200+325 \mathrm{NM} \\
-325\end{array}$ & $\begin{array}{l}541 \\
596 \\
746\end{array}$ & $\begin{array}{l}43.6 \\
42.9 \\
48.5\end{array}$ & $\begin{array}{l}345 \\
331 \\
294\end{array}$ & $\begin{array}{l}368 \\
344 \\
307\end{array}$ & $\begin{array}{l}512 \\
433 \\
404\end{array}$ \\
\hline 81ANK237A & $\begin{array}{l}+100 \\
-100+150 \\
-325\end{array}$ & $\begin{array}{l}422 \\
482 \\
666\end{array}$ & $\begin{array}{l}26.4 \\
32.3 \\
37.4 \\
37\end{array}$ & $\begin{array}{l}340 \\
345 \\
302\end{array}$ & $\begin{array}{l}421 \\
364 \\
312\end{array}$ & $\begin{array}{l}896 \\
492 \\
385\end{array}$ \\
\hline 80AAF039A & $\begin{array}{l}+150 \\
-250+250 \\
-325\end{array}$ & $\begin{array}{l}120 \\
135 \\
154\end{array}$ & $\begin{array}{l}7.32 \\
8.80 \\
9.85\end{array}$ & $\begin{array}{l}321 \\
347 \\
341\end{array}$ & $\begin{array}{l}327 \\
350 \\
345\end{array}$ & $\begin{array}{l}369 \\
372 \\
370\end{array}$ \\
\hline
\end{tabular}




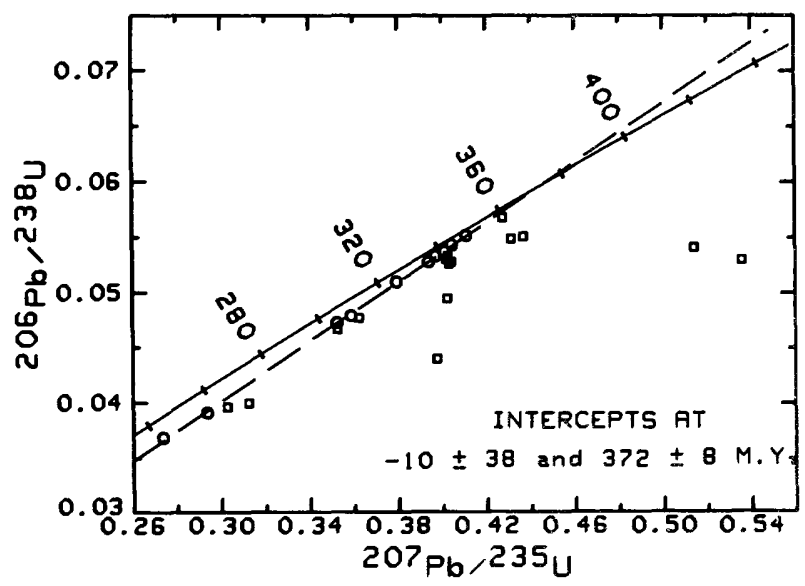

A.

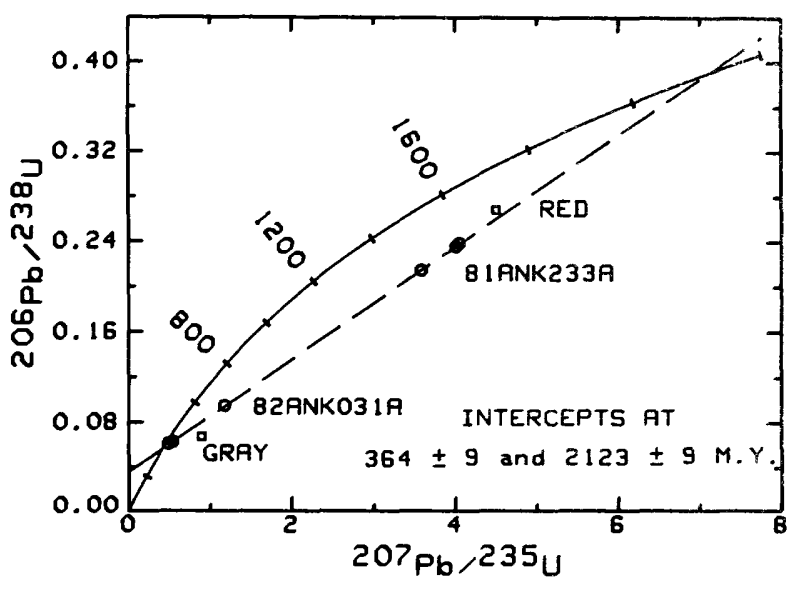

B.

Figure 33.--Concordia plots of U-Pb data from zircons from metaigneous rocks in the northern Mount Hayes quadrangle, eastern Alaska Range (A), Metarhyolite samples (81ANK233A and 82 ANK031A) from the Jarvis Creek Glacier terrane. (B), Metaigneous rocks in Macomb, Jarvis Creek Glacier, and Hayes Glacier terranes. Best-fit line calculated only through data points shown as circles. Square-shaped data points were not used in regression calculations.

same ridge for $\mathrm{U}-\mathrm{Pb}$ geochronologic studies. The U$\mathrm{Pb}$ ages of three splits of zircon from sample 82ANK031A are distinctly lower than those from sample 81ANK233A, suggesting a Devonian age of extrusion (fig. 33B, table 11). Thus, data from two samples within a single unit result in differing interpretations. To resolve this conflict, an additional split of 81ANK233A was carefully prepared using a magnetic separator. A best-fit line through the three smallest size fractions of $81 \mathrm{ANK} 233 \mathrm{~A}$ and the three previously mentioned fractions results in concordia intercept ages of 364 \pm 9 m.y. and $2123 \pm 9$ m.y. (fig. 33B). Two relatively coarse-grained, gray and red fractions in 81ANK 233A (fig. 33B) were excluded from the calculations because: (1) the gray fraction contains five times more $U$ than the other fractions and the location of its data point (fig. 33B) suggests modern lead loss caused by metamictization and dilatancy; and (2) the distance from the best-fit line of the red point is in excess of analy tical uncertainty, suggesting multiple episodes of lead loss of undetermined age. We interpret these results to indicate that the protoliths of the Jarvis Creek Glacier metavolcanic rocks were extruded at about $364+9$ m.y. ago (Devonian), having been derived from an Early Proterozoic source. This inheritance age is consistent with ages reported in previous studies in the YukonTanana Upland (Aleinikoff and others, 1981).

The above data and stratigraphic, structural, and field interpretations (Nokleberg and Aleinikoff, 1985) indicate that the Lake George, Macomb, Jarvis Creek Glacier, and Hayes Glacier terranes represent, from north to south, successively shallower levels of a single, now highly metamorphosed and deformed Devonian submarine igneous ars. The augen gneiss to the north and east, derived from Mississippian granitic plutonic rocks (Dusel-Bacon and Aleinikoff, 1985), may represent deeper-level parts of this arc. The arc is interpreted by Nokleberg and Aleinikoff (1985) as either an islandarc containing a slice of continental crust which contaminated the magmas, or as a submerged continental margin arc, with continental detritus shed into a companion trench- and subduction-zone system. A continental margin setting is indicated also by the abundant quartz-rich schists in tr ? Lake George, Jarvis Creek Glacier, and Hayes Glacier terranes, many with zircons containing Early Proterozoic lead (Aleinikoff and others, 1984; Dusel-Bacon and Aleinikoff, 1985).

\section{REFERENCES CITED}

Aleinikoff, J. N., 1984, Age and origin of metaigneous rocks from terranes north and scilth of the Denali fault, Mount Hayes quadrangle, east-central Alaska (abs.): Geological society of America Abstracts with Programs, v. 16, p. 266.

Aleinikoff, J. N., Dusel-Bacon, Cynthia, Foster, H.L., and Futa, Kiyoto, 1981, Proterozoic zircon from augen gneiss, Yukon-Tanana Upland, east-central Alaska: Geology, v. 9, F. 469473.

Aleinikoff, J. N., Foster, H. L., Nokleberg, W. J., and Dusel-Bacon, Cynthia, 1984, Isotop:c evidence for detrital zircons from Early Proterozoic crustal material, east-central Alaska, in Coonrad, W. L., and Elliott, R. L., eds., The United States Geological Survey in AlaskaAccomplishments during 1981: U.S. Geological Survey Circular 868, p. 43-45. 
Aleinikoff, J. N., and Nokleberg, W. J., 1984a, Early Proterozoic metavolcanic rocks in the Jarvis Creek Glacier tectonostratigraphic terrane, Mount Hayes C-6 quadrangle, eastern Alaska Range, Alaska, in Reed, K. M., and BartschWinkler, Susan, eds., The United States Geological Survey in Alaska-Accomplishments during 1982: U.S. Geological Survey Circular 939 , p. $40-44$.

Aleinikoff, J. N., and Nokleberg, W. J., 1984b, Uranium-lead geochronology of a metarhyolite from the Pingston terrane, Mount Hayes C-6 quadrangle, eastern Alaska Range, Alaska, in Coonrad, W. L., and Elliott, R. L., eds., The United States Geological Survey in AlaskaAccomplishments during 1981: U.S. Geological Survey Circular 868, p. 73-75.

Aleinikoff, J. N., and Nokleberg, W. J., 1985, Age of intrusion and metamorphism of a granodiorite in the Lake George terrane, northeastern Mount Hayes quadrangle, Alaska, in BartschWinkler, Susan, and Reed, K. M., eds., The United States Geological Survey in AlaskaAccomplishments during 1983: U.S. Geological Survey Circular 945, p. 62-75.
Dusel-Bacon, Cynthia, and Aleinikoff, J. N., 1985, Petrology and tectonic significance of augen gneiss from a belt of Mississippian granitoids in the Yukon-Tanana terrane, east-central Alaska: Geological Society of America Bulletin, v. 96, p. 411-425.

Jones, D. L., Silberling, N. J., Berg, H. C., and Plafker, George, 1981, Map shoving tectonostratigraphic terranes of Alaska, columnar sections, and summary descriptions of terranes: U.S. Geological Survey Open-File Report 81-792, 20 p., 1 sheet, scale 1:2,500,000.

Nokleberg, W. J., and Aleinikoff, J. N., 1985, Summary of stratigraphy, structure, end metamorphism of Devonian igneous-arc terranes, northeastern Mount Hayes quadrengle, eastern Alaska Range, Alaska, in Bartsch-Winkler, Susan, ed., The United States Geological Survey in Alaska-Accomplishments during 1984: U.S. Geological Survey Circular 967, this volume.

Nokleberg, W.J., Aleinikoff, J.N., and Lange, I.M., 1983 , Origin and accretion of Andean-type and island arc terranes of Paleozoic age juxtaposed along the Hines Creek fault, I"ount Hayes quadrangle, eastern Alaska Range, Alaska: Geological Society of America Abstracts with Programs, v. 15, p. 427.

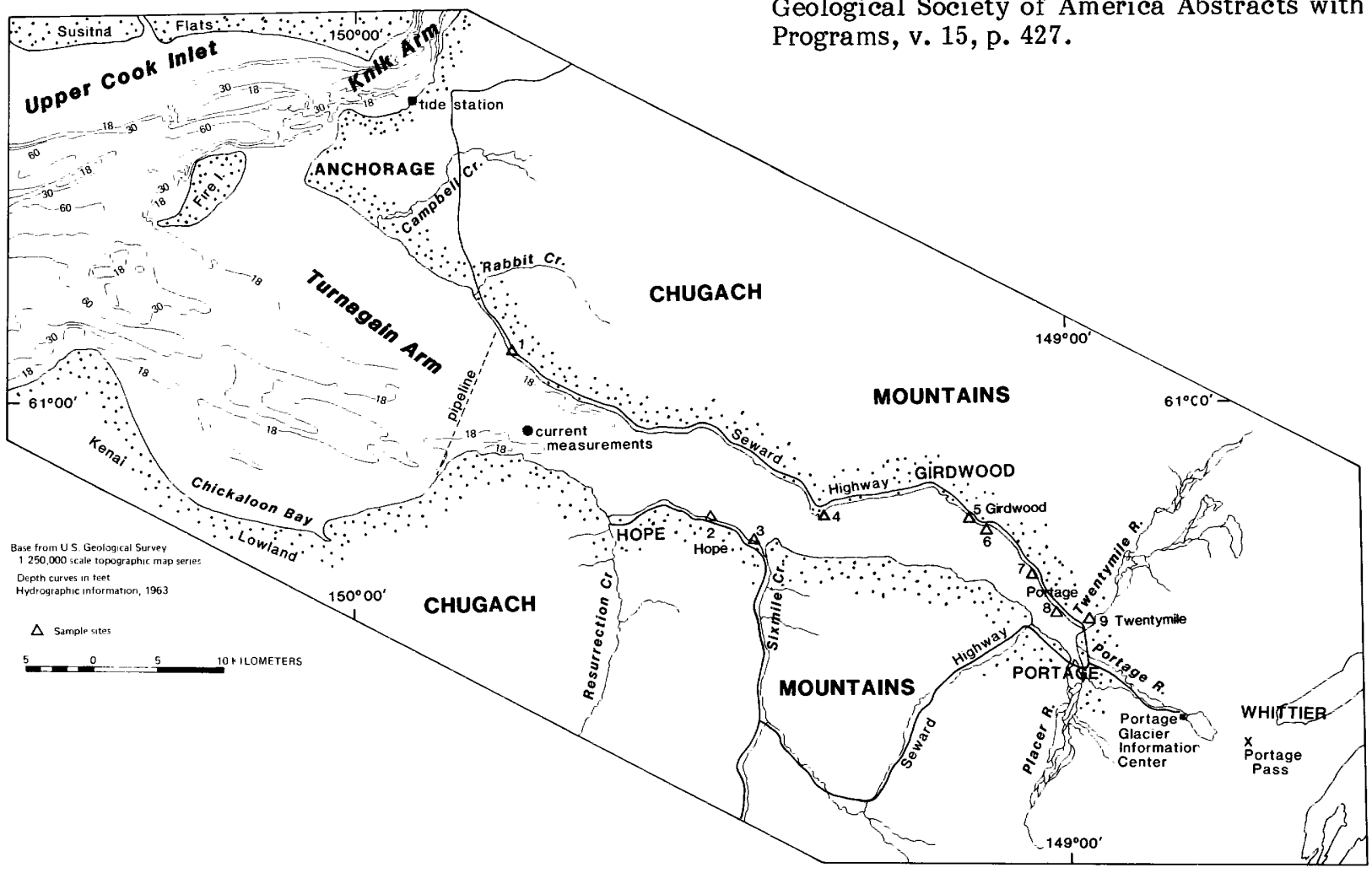

Figure 34.--Index map of Turnagain Arm showing the Anchorage tidal station location (square), current measurement site of the Alaska Department of Highways (1969) (black dot), ard tide observation, water level, and suspended sediment sites (numbered triangles). 
Nokleberg, W.J., Schwab, C.E., Miyaoka, R.T., and Buhrmaster, C.L., 1984, Stratigraphy, petrology, and structure of the Pingston terrane, Mount Hayes $\mathrm{C}-5$ and $\mathrm{C}-6$ quadrangles, eastern Alaska Range, Alaska, in Coonrad, W.L., and Elliott, R.L., eds., The United States Geological Survey in Alaska-Accomplishments during 1981: U.S. Geological Survey Circular 868 , p. $70-73$.

Reviewers: Cynthia Dusel-Bacon and M. A. Lanphere

\section{RECONNAISSANCE HYDROLOGY AND SUSPENDED SEDIMENT ANALYSIS, TURNAGAIN ARM ESTUARY, UPPER COOK INLET}

\section{Susan Bartsch-Winkler, Richard P. Emanuel, and Gary R. Winkler}

Turnagain Arm estuary, a southeastern extension of Upper Cook Inlet near Anchorage (fig. 34), is macrotidal, with a maximum semidiurnal range at Anchorage of about $11.4 \mathrm{~m}$. (Variation in Turnagain Arm tide depends on daily tide range, wind, and amount of precipitation.) Because of rapid shallowing and the funnel shape of the estuary, a tidal bore is produced when the tide enters the Arm. At the mouth, low tide is delayed about one hour from the time of low tide at the Anchorage tide station, located about $12 \mathrm{~km}$ to the NE (fig. 34). At the head (at Portage), about $85 \mathrm{~km}$ to the SE, delay in low tide is $5-6 \mathrm{~h}$ past low tide at the tide station (table 12). Flood currents are stronger but of shorter duration than the ebb currents, in part due to this flood-tide delay.

The Upper Cook Inlet area is in a subarctic zone, lying in a transitional area between continental and maritime climates (Selkreig, 1972). Wind velocity may be high, since Turnagain Arm serves to channel easterly winds resulting from pressure differentials between Gulf of Alaska and interior weather systems. Unofficial wind velocity records at Portage Glacier indicate equinoctial winds exceeding $150 \mathrm{~km} / \mathrm{h}$ (Selkreig, 1972; U.S. Forest Service, unpublished data, 1982) and frequent $50-70 \mathrm{~km} / \mathrm{h}$ winds (Alaska Department of Transportation, 1969).

Like Upper Cook Inlet (Sharma and Burrell, 1970) and Knik Arm (Bartsch-Winkler, 1982), Turnagain Arm is an area of contemporary deposition (Bartsch-Winkler and Ovenshine, 1984). At low tide, approximately 90 percent of the Arm is exposed as elongate bars of easily eroded silt and fine sand dissected by braided tidal channels of unknown depth and texture. Nine glacial streams flow into Turnagain Arm; of these, four have been measured sporadically for discharge rates and record average annual suspended sediment loads of 2.5 million tons (J.M. Childers in Gatto, 1976).
A few oceanographic studies have been conducted near the mouth (National Oceanographic and Atmospheric Administration, 1979; Alaska Department of Transportation, 1969). This is the first reporting of hydrological conditions in the estuary above the intertidal limit.

Current velocity measurements at a single site in the part of Turnagain Arm located below low tide level provide only a guide to tidal current characteristics farther landward in the intertid-1 parts of the estuary where bores form regularly (fig. 34). Measurements taken at $3 \mathrm{~m}$ depth show slerk high water prevailing for less than $15 \mathrm{~min}$ and current velocity reaching a maximum about $45 \mathrm{~min}$ after the onset of flooding (Alaska Department of Transportation, 1969). Conversely, peak velocity during ebb tide occurs at mid-cycle. Measurements of height in tide made during one cycle at several sites in upper Turnagain Arm (fig. 35) confirm that the slope of the flood surface level curve in a given tidal cycle is slightly greater than that of the ebb tide curve, implying faster current velocitie? during the flood stage.

Table 12.--Difference in time of arrival of low and high tides at selected sites in Turnagain Arm from the published low and high tide times at the Anchorage tidal station: $(-)$, delay in time; $(+)$, advance in time

\begin{tabular}{|c|c|c|c|c|}
\hline \multirow{2}{*}{$\begin{array}{l}\text { Site } \\
\text { no. }\end{array}$} & \multirow{2}{*}{ Date } & \multirow{2}{*}{$\begin{array}{l}\text { Tide height } \\
\text { at Anchorage } \\
\text { (ft) }\end{array}$} & \multicolumn{2}{|c|}{ Tide delay at site } \\
\hline & & & $\begin{array}{c}\text { Low } \\
(\mathrm{hr}: \mathrm{min})\end{array}$ & $\begin{array}{l}\text { High } \\
\text { (hr:min }\end{array}$ \\
\hline 1 & $06 / 19 / 82$ & 30.6 & $-0: 50$ & - \\
\hline 2 & $\begin{array}{l}05 / 16 / 81 \\
06 / 18 / 82 \\
06 / 19 / 82\end{array}$ & $\begin{array}{l}28.1 \\
29.2 \\
30.6\end{array}$ & $\begin{array}{l}-1: 52 \\
-1: 46 \\
-1: 46\end{array}$ & $\begin{array}{c}+0: 08 \\
-0: 21 \\
-\end{array}$ \\
\hline 3 & $06 / 19 / 82$ & 30.6 & $-1:$ & - \\
\hline 4 & $06 / 19 / 82$ & 30.6 & $-2: 19$ & - \\
\hline 5 & $\begin{array}{l}07 / 16 / 81 \\
08 / 07 / 81 \\
09 / 23 / 81 \\
06 / 19 / 82 \\
06 / 26 / 82\end{array}$ & $\begin{array}{l}30.5 \\
20.3 \\
26.8 \\
30.6 \\
26.1\end{array}$ & $\begin{array}{l}-4: 09 \\
-4: 55 \\
-4: 27 \\
-3: 51 \\
-3: 41\end{array}$ & $\begin{array}{l}-\overline{-1: 15} \\
-1: 20 \\
-0: 42 \\
-0: 49\end{array}$ \\
\hline 6 & $06 / 19 / 82$ & 30.6 & $-4: 09$ & - \\
\hline 7 & $06 / 19 / 82$ & 30.6 & $-4: 37$ & 一 \\
\hline 8 & $\begin{array}{l}06 / 21 / 82 \\
06 / 26 / 82\end{array}$ & $\begin{array}{l}34.7 \\
26.1\end{array}$ & $\begin{array}{l}-5: 05 \\
-4: 38\end{array}$ & - \\
\hline 9 & $\begin{array}{l}06 / 19 / 82 \\
06 / 21 / 82 \\
06 / 26 / 82\end{array}$ & $\begin{array}{l}26.1 \\
30.6 \\
30.6\end{array}$ & $\begin{array}{l}-5: 26 \\
-5: 25 \\
-4: 58\end{array}$ & $\begin{array}{l}-\overline{-1: 10} \\
-1: 01\end{array}$ \\
\hline
\end{tabular}


Table 13.--Maximum and minimum values of suspended sediment and specific conductance measurements from various sites and at various times during the tidal cycle, May through September, 1981 and 1982, Turnagain Arm, Alaska. Asterisk den tes samples taken at three sites during the flood tidal cycle of $06 / 26 / 82$

\begin{tabular}{cc|cc|cc}
\hline $\begin{array}{l}\text { Site } \\
\text { No. }\end{array}$ & Date & \multicolumn{2}{|c|}{$\begin{array}{c}\text { Specific } \\
\text { Conductance Values } \\
\text { (micromhos) }\end{array}$} & \multicolumn{2}{c}{$\begin{array}{c}\text { Suspended } \\
\text { Sediment Values } \\
\text { (milligrams/liter) }\end{array}$} \\
\hline & & Maximum & Minimum & Maximum & Minimum \\
2 & $05 / 16 / 81$ & 27,440 & 22,260 & - & - \\
& $06 / 18 / 82$ & 22,230 & 390 & 4,440 & 180 \\
5 & $07 / 16 / 81$ & 7,100 & 120 & 2,000 & 210 \\
& $08 / 07 / 81$ & 890 & 100 & 1,960 & 210 \\
& $09 / 23 / 81$ & 5,770 & 160 & 1,230 & 40 \\
& $06 / 19 / 82$ & 16,080 & 170 & 2,790 & 130 \\
& $06 / 26 / 82$ & $* 22,400$ & $* 760$ & $* 1,770$ & $* 40$ \\
& $06 / 21 / 82$ & 12,950 & 275 & 4,200 & 110 \\
& $06 / 26 / 82$ & $* 6,900$ & $* 160$ & $* 4,100$ & $* 5$ \\
& $06 / 26 / 82$ & $* 90$ & $* 70$ & $* 1,870$ & $* 90$ \\
\hline
\end{tabular}

Suspended sediment samples were collected from tidal channel surfaces during both flood and ebb tide (fig. 34). Sieve and hydrophotometer size analyses indicate suspended sediment ranges from very fine sand to clay; medium silt forms the largest category of the total, averaging 35 percent. In all samples, clay-size material ranges from 2 to 4 percent. Suspended sediment content at the surface ranges from $4,440 \mathrm{mg} / \mathrm{L}$ at Hope (site 2) to $<10 \mathrm{mg} / \mathrm{L}$ at Portage (site 8)(table 13); maximum values were recorded (1) during lowest ebb phases, when bottom sediments in shallowing channels were entrained, (2) just after the onset of flood tide when the tidal bore occurred and current velocities increased, and (3) on windy days when waves stirred bottom sediment and wind incorporated sediment from the exposed bars. At Portage, where tidal channel depths are shallowest and the flood cycle shortest, suspended sediment values peaked $(4,200$ $\mathrm{mg} / \mathrm{L}) 30 \mathrm{~min}$ before and after low tide. Near the mid-point in the Arm (Girdwood, site 5), values increase abruptly on arrival of the bore and peak $(2,790 \mathrm{mg} / \mathrm{L}) 30-60 \mathrm{~min}$ afterwards. At Hope (site 2), maximum entrainment of sediment occurs at low tide $(4,440 \mathrm{mg} / \mathrm{L})$, decreasing within $30 \mathrm{~min}$ to levels typical of high tide stage $(<200 \mathrm{mg} / \mathrm{L})$. When sea level is about $2 \mathrm{~m}$, surface suspended sediment values decrease. At slack high tide, as current velocities slow and water depth is maximum, values decrease to $<100 \mathrm{mg} / \mathrm{L}$. The bore and ensuing currents greatly increase entrained surface suspended sediment up to mid-tide stage; however, high winds and tidal currents can generate significant waves, which reduce the effect of the bore. Apparently, wind-waves combined with tidal currents may entrain sediment on the surface to a water depth of about $2 \mathrm{~m}$, coincidentally the estimated maximum height of the bore.

In Cook Inlet (fig. 34), average salinity values decrease with increasing distance from the mouth toward the head (Murphy and others, 1972). Measurements at the mouth indicate an average salinity of $31 \mathrm{ppt}$ (close to normal sea water average of $35 \mathrm{ppt}$ ), but near the head of Upper Coo'r Inlet and at mouth of Knik Arm, salinity values vary from $6 \mathrm{ppt}$ in the summer to slightly more than $20 \mathrm{ppt}$ in the winter (Murphy and others, 1972). Increase in salinity in winter may be due to decrease in runoff and increased solute segregation when sea water freezes. The Susitna, Knik, and Matenuska Rivers contribute approximately 70 percent of freshwater discharged annually into Cook Inlet (Gatto, 1976). During calm summer periods, freshwater is observed to override saltwater, particularly near the Susitna River mouth during high discharge (Murphy and others, 1972), but near the mouth of Knik Arm at Fire Island, a high degree of mixing occurs (Murphy and others, 1972).

During spring and summer morths, specific conductance values, which are directly related to salinity values (Hem, 1959), were reccrded at sites in Turnagain Arm. Preliminary results show a pattern of decreasing conductance hesdward in the estuary and seasonal and daily variability dependent on runoff (fig. 36; table 13), similar tc the data for Cook Inlet. In Turnagain Arm, specific conductance has higher range and value at Hope (390-27,440 micromhos) and lower range and value at Twentymile River (site 9) (70 and 90 micromhos essentially freshwater). Measurements made in mid-May show higher conductance values than samples taken later, reflecting lower runoff to 


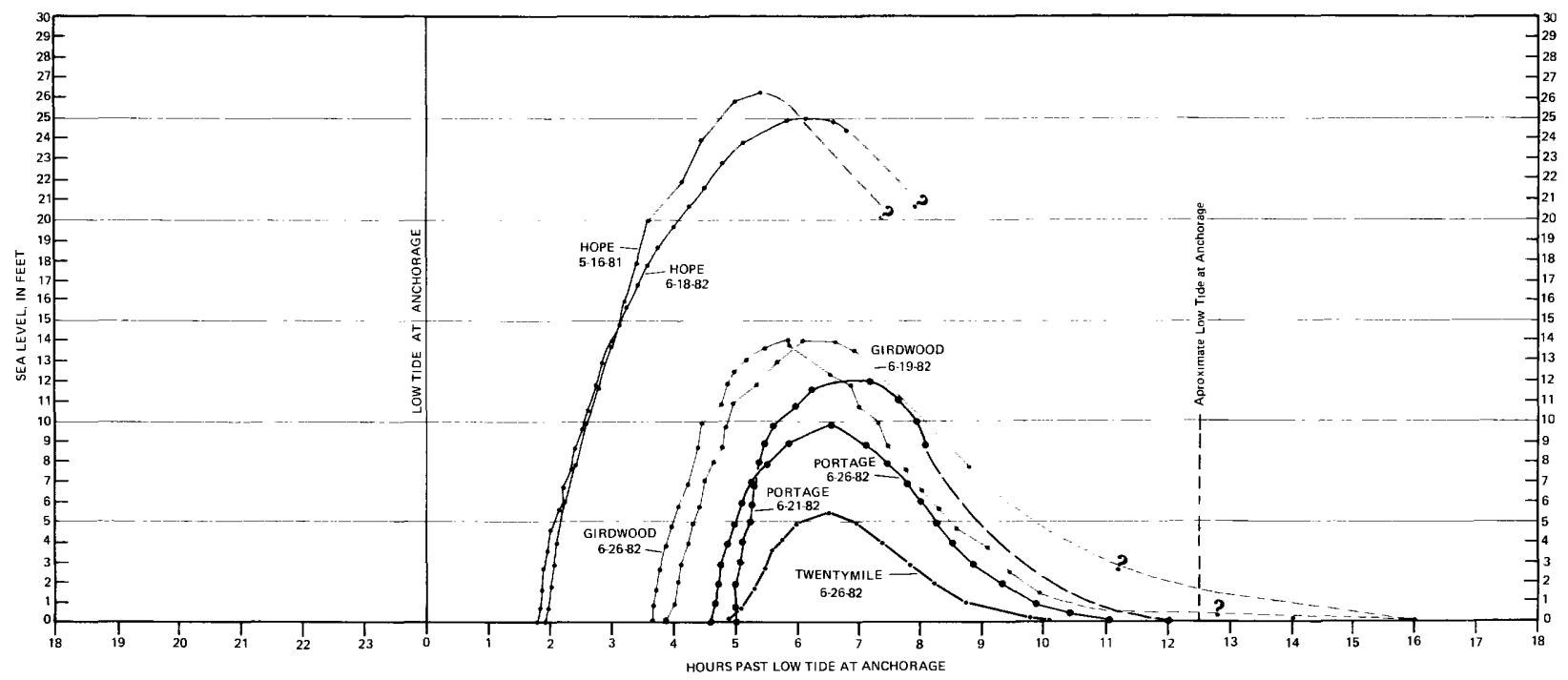

Figure 35.--Plot of water level height versus time at sample sites shown in figure 34. Data curve is queried where extrapolated.

Turnagain Arm from high-altitude snowmelt and less rainfall in early spring.

Movement of the saline wedge within Turnagain Arm can be successfully monitored using specific conductance measurements. Readings of specific conductance in upper Turnagain Arm for a single tidal cycle were taken at sites 5,8 , and 9 on June 26, 1982, during conditions of low precipitation and calm weather (table 13). At Girdwood, the most seaward station occupied that day, conductance values increased 45 min after low tide at the site, while at Portage, values increased 55 min after low tide there. At Twentymile River, the most headward station, values did not increase, indicating that the saline wedge did not reach the head of the estuary. At both Girdwood and Portage, conductance values continued to increase for a period of 40 and $30 \mathrm{~min}$, respectively, after high tide at each site. In Turnagain Arm, circulation patterns resulting from the Coriolis force may push flood water along the south side and return it along the north side of the estuary, so that ebbing water continues to have high conductance values even during lowering tide. These results indicate that ebb and flood currents apparently flow along separate paths within Turnagain Arm that coincide with the expected Coriolis pattern. No successful current tests have been conducted above the intertidal limit to verify this theory.

\section{REFERENCES CITED}

Alaska Department of Highways, 1969, Field and laboratory soils data, Turnagain Arm Crossing, Project No. F-021-2(10), Anchorage District: unpublished report, $115 \mathrm{p}$.

Bartsch-Winkler, Susan, 1982, Physiography, texture, and bedforms in Knik Arm, Upper Cook Inlet,
Alaska, during June and July 1980: U.S. Geological Survey Open-File Report 82-464.

Bartsch-Winkler, Susan, and Ovenshine, A.T., 1984, Macrotidal subarctic environment of Turnagain and Knik Arms, Upper Cook Inlet, Alaska: Sedimentology of the intertidal zone: Journal of Sedimentary Petrology, v. 54, no. 4, p. 1219-1236.

Hem, J.D., 1959, Study and interpretation of the chemical characteristics of natural water: U.S. Geological Survey Water Supply Paper 1473,269 p.

Gatto, L.W.,1976, Baseline data on the oceancgraphy of Cook Inlet, Alaska: U.S. Army Corps of Engineers, CRREL Report 76-25, 81 p.

Murphy, R.S., Carlson, R.F., Nyquist, David, and Britch, Robert, 1972, Effect of waste discharges into a silt-laden estuary $-a$ case study of Cook Inlet, Alaska: Institute of Water Resources Report, Fairbanks, University of Alaska, p. 6-25.

National Oceanographic and Atmospheric Administration, National Ocean Surveys, 1979, Cook Inlet; Fire Island to Goose Creek, Nautical Chart Catalog, Number 3, Panels K, L, DMA Stock Number 16AHA 16664, scale 1:40,000.

Selkreig, L.L., ed., and E.H. Buck, R.T. Euffler, O. E. Cote, C. D. Evans, and S. G. Fisk, 1972, Environmental Atlas of the Greater Anchorage Area Borough, Alaska: Arctic Environmental Information and Data Center, Anchorage, University of Alaska, 105 p.

Sharma, G.C., and Burrell, D.C., 1970, Sedim entary environments and sediments of Cook Inlet, Alaska: American Association of Petroleum Geologists Bulletin, v. 54, no. 4, p. 647-654.

Reviewers: S.M. Karl and J.M. Knott 


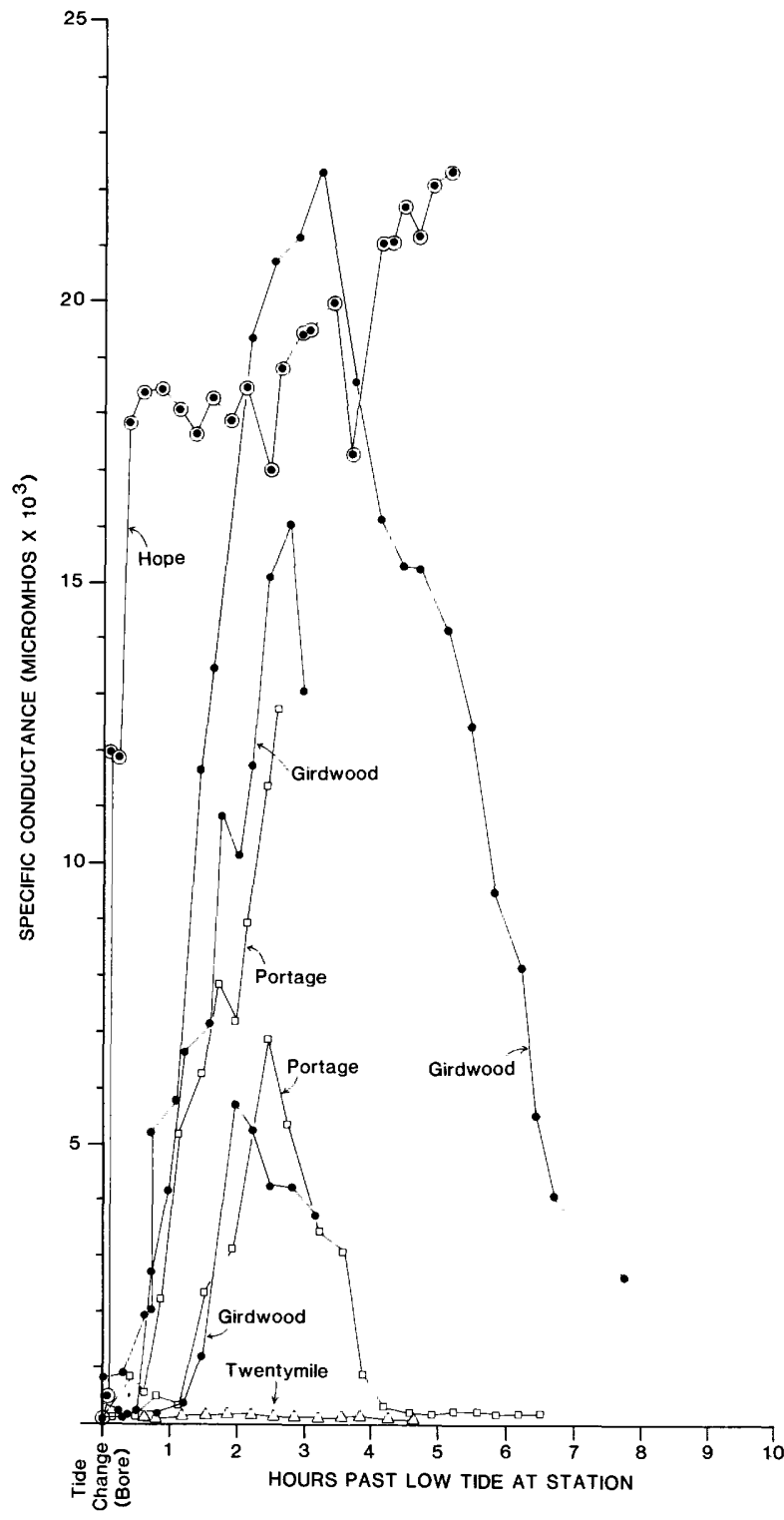

Figure 36.--Measurements of specific conductance taken throughout the tidal cycle at various sites (see figure 34 for locations).

\section{GRAVITY AND MAGNETIC MODEL OF A PART OF THE 1984 TACT LINE, CHUGACH MOUNTAINS AND SOUTHERN COPPER RIVER BASIN}

\section{David L. Campbell and David F. Barnes}

A model of anomalous density and magnetic susceptibility bodies was constructed along the southern part of the 1984 Trans-Alaskan Crustal Transect (TACT) line in the Chugach Mountains and southern Copper River basin (fig. 37; see also Plafker and others, 1985; Fuis and others, 1985).
The profile follows the Copper River meridian (approximately long $145^{\circ} 19^{\prime} \mathrm{W}$.) from lat $60^{\circ} 45^{\prime} \mathrm{N}$. just south of Cordova Peak to lat $62^{\circ}{ }^{\circ} 5^{\prime} \mathrm{N}$. near Gulkana (fig. 38). The distance coordirate scale has its origin at Richardson Highway shot point 12 (at Tiekel River) of the seismic refraction survey. The southernmost shot point for the refraction work was near coordinate -20 ; south of that point, the model is not constrained by seismic data.

The aeromagnetic and complete Bouguer gravity anomaly fields for the bodies shown in figure 37 were modeled using a program by Carnpbell (1983). The bodies shown were assumed to extend unchanged perpendicular to the plane of the section for varying strike-length distances $\mathrm{Y} 1$ and $\mathrm{Y} 2$ (table 14 ), and then to be vertically cut off [the "2 1/2-dimensional geometry" of Shuey and Pasquale (1973)]. Y1 and Y2 were chosen to match strike lengths of corresponding anomalies on the aeromagnetic map. Exploiting the ccmplementary strengths of the different geophysical techniques, horizontal and near-horizontal interfaces were located by the seismic work and vertical and nearvertical interfaces were located by gravity and magnetic anomalies. All bodies were assumed to be magnetized in the direction of the errth's present field, of $56400 \mathrm{nT}$ magnitude, $76^{\circ}$ inclination, and $28^{\circ}$ easterly declination. The effective magnetic susceptibility for each body (table 14) may include a remanent magnetization component parallel to the earth's field. Possible remanent magnetizations in other directions were neglected in making this model.

To get the observed gravity field profile, complete Bouguer gravity anomaly values from all stations within $10 \mathrm{~km}$ of the Copper River meridian were projected normally onto it. The observed gravity profile is not closely controlled cver the Chugach Mountains where there are few gravity stations. North of coordinate -10 , however, the gravity field has an average of more than 1 station per $\mathrm{km}$ of profile. Observed magnetic fields were digitized directly from contoured aeromagnetic maps (U.S. Geological Survey, 1979a, b; Andreasen and others, 1958) and generally reflect tre field along the Copper River meridian. North of $\varepsilon$ pproximately coordinate 90 , the Copper River meridian passes over a magnetic feature which appers to reflect shallower basement rocks than those under the seismic line which follows the Richardson Highway. Here, the observed magnetic field represents values along the Richardson Highway that are projected onto the profile. Along most of the profile, all major gravity and magnetic features are long and trend perpendicular to it, so that artifacts $d$ "e to the projection process were minor and the $21 / 2$-dimensional approximation used in the modeling was justified.

Neglecting short-wavelength highs that can be ascribed to specific shallow sourees such as the Border Ranges mafic-ultramafic unit (Burns, 1983), the observed gravity and magnetic fields are high 

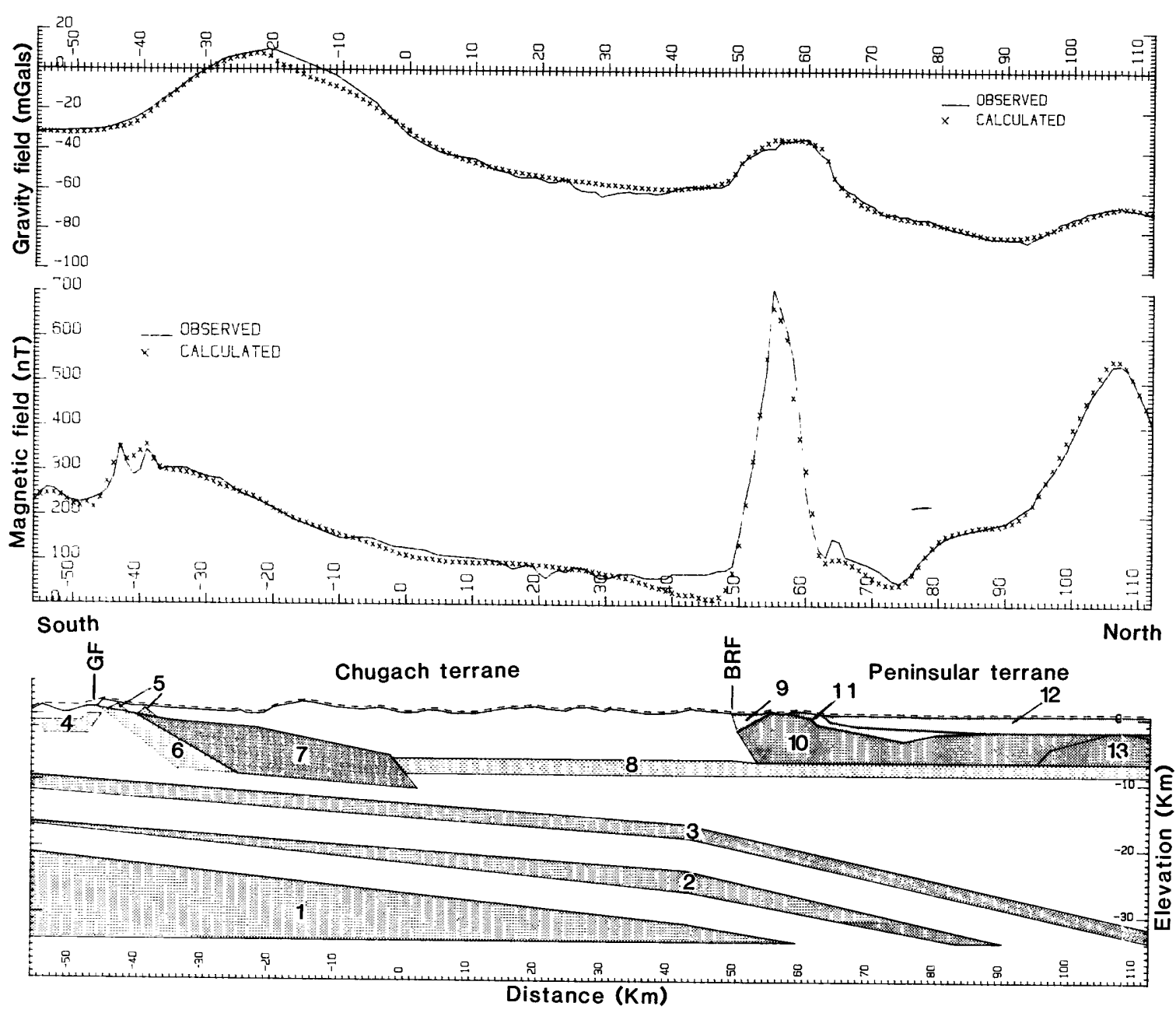

Figure 37.--Gravity and magnetic models of possible bodies in the Chugach Mountains and southern Copper River basin along the southern part of the 1984 TACT line. Light dot pattern indicates body with anomalous density, coarse dot pattern indicates body with anomalous magnetic susceptibility, and heavy dot pattern indicates body with both anomalous density and magnetic susceptibility. Most horizontal interface depths were determined by the seismic refraction modeling of Fuis and others (this volume). GF = Gravina fault; BRF = Border Ranges fault.

near the coast and decrease inland (northward), becoming relatively flat north of the Border Ranges fault. This general trend was modeled by projecting the deep interfaces observed by the seismic refraction survey southwards to the vicinity of the continental slope and assuming that the projected higher velocity $(7.6 \mathrm{~km} / \mathrm{s}$ and greater) zones also have high density and magnetic susceptibility. Bottoms of the high density/susceptibility layers were taken at 34 $\mathrm{km}$, a depth found by trial and error to give the best shape for the regional fields. This depth could represent the Curie isotherm in the magnetic model or the depth of regional isostatic compensation in the gravity model.

Having defined the regional field in this way, departures from it were ascribed to bodies in the upper ( $<10 \mathrm{~km}$ depth) crust, many of which erop out at the surface. Outcropping bodies proje?ted to depth in the model include: body 4, a magnetic Tertiary volcanic and sedimentary unit which occurs at the surface just to the southwest of the profile (Winkler and Plafker, 1981); body 5, a Cretaceous volcanic unit (Winkler and Plafker, 1981); body 10, the Border Ranges mafic-ultramafic unit of Burns (1983); and body 11, the Talkeetna Formation (Winkler and others, 1980). If possible, th? same body was used to model both gravity and magnetic fields. This was not possible for bodies 6 and 7, where a gravity high falls substantially nortl of the corresponding magnetic anomaly. Therefore, the unit represented by bodies 6 and 7 was assumed to be composite, with a high-density part to the north, 
but moderately magnetic in both parts.

In general, a strong effort was made to achieve agreement between seismic and potential field models. This effort failed over the Copper River Basin, where the depth to seismically-modeled basement is about twice the value we prefer. This discrepancy may be due to layers of well-indurated sedimentary rocks in the basin fill that are too thin to be resolved by any of our present data. Body 11, the Talkeetna Formation, schematically represents such a well-indurated zone, but true definition of its properties or position at depth is not possible from the potential field data.

\section{REFERENCES CITED}

Andreasen, G.E., Dempsey, W.J., Henderson, J.R., and Gilbert, F.P., 1958, Aeromagnetic map of the Copper River basin, Alaska: U.S. Geological Survey Geophysical Investigations Map GP-156, scale 1:125,000.

Burns, L.E., 1983, The Border Ranges ultramafic and mafic complex: plutonic core of an intraoceanic island are (Alaska): PhD. dissertation, Stanford, California, Stanford University, 203 p.

Campbell, D.L., 1983, BASIC programs to calculate gravity and magnetic anomalies due to 2-1/2dimensional prismatic bodies: U.S. Geological Survey Open-File Report 83-154, 38 p.

Fuis, G.S., Ambos, E.L., Mooney, W.D., and Page, R.A., 1985, Preliminary results of TACT seis- mic-refraction survey of southern Alaska, in Bartsch-Winkler, Susan, ed., The U.S. Geological Survey in Alaska-Accomplishments during 1984: U.S. Geological Survey Circular 967, this volume.

Plafker, George, and Nokleberg, W.J., 1985, Summary of the 1984 TACT geologic studies in the northern Chugach Mountains and southern Copper River basin, in Bartsch-Winkler, Susan, ed., The U.S. Geological Survey in AlaskaAccomplishments during 1984: U.S. Geological Survey Circular 967, this volume.

Shuey, R.T., and Pasquale, A.S., 1973, End corrections in potential field modelling: Geophysical Prospecting, v. 27, p. 749-760.

U.S. Geological Survey, 1979a, Aeromagnetic map of parts of the Cordova and Middleton Island $1^{\circ} \times 3^{\circ}$ quadrangles, Alaska: U.S. Geological Survey Open-File Report 79-223, scale $1: 250,000$.

U.S. Geological Survey, 1979b, Aeromagnetic map of part of the Valdez $1^{\circ} \times 3^{\circ}$ quadrangle, Alaska: U.S. Geological Survey O-en-File Report 79-381, scale 1:250,000.

Winkler, G.R., Silberman, M.L., Grantz, Arthur, Miller, R.J., and MacKevett, E.M., Jr., 1980, Geologic map and summary geochronology of the Valdez quadrangle, southern Alaska: U.S. Geological Survey Open-File Report 80-892-A, scale $1: 250,000$.

Winkler, G.R., and Plafker, George, $19^{\wedge} 1$, Geologic map and cross-sections of the Cordova and

Table 14.--Parameters for interpreted bodies shown in figure 37. $\mathrm{Y} 1$ and $\mathrm{Y} 2$ are distarses the bodies are assumed to extend in front of and behind the plane of the figure, respectively. Listed density values represent differences from densities of a reference section supposed here to have $2.67 \mathrm{~g} / \mathrm{cm}^{3}$ density to $8.8 \mathrm{~km}$ depth and $2.90 \mathrm{~g} / \mathrm{cm}^{3}$ density from $8.8 \mathrm{~km}$ to $34 \mathrm{~km}$ deptr. Many other reference sections may be devised, however, which would lead to as good or better agreement with lithologies and measured seismic velocities. Listed velocity values are taken from Fuis and others (1985). In order to match the observed gravity field, a constant value of $82 \mathrm{mGal}$ was added to the gravity fields calculated for the bodies listed. HVL = high-velocity layer; $L V L=$ low-velocity layer; serp = serpentinized; $u m=$ ulramafic; $\mathrm{Ct}=$ Chugach ter -ane; $\mathrm{Pt}$ $=$ Peninsular terrane: $\mathrm{CRB}=$ Copper River basin

\begin{tabular}{ccccccl}
\hline Body & $\begin{array}{c}\mathrm{Y} 1 \\
(\mathrm{~km})\end{array}$ & $\begin{array}{c}\mathrm{Y} 2 \\
(\mathrm{~km})\end{array}$ & $\begin{array}{c}\text { Density } \\
\left(\mathrm{g} / \mathrm{cm}^{3}\right)\end{array}$ & $\begin{array}{c}\text { Susceptibility } \\
(\mathrm{cgs})\end{array}$ & $\begin{array}{c}\text { Velocity } \\
(\mathrm{km} / \mathrm{s})\end{array}$ & \multicolumn{1}{c}{ Represents } \\
\hline 1 & 100 & 100 & 0.10 & 0.005 & 8.0 & um HVL in subducted plate \\
2 & 100 & 100 & 0.05 & 0.001 & 8.0 & mafic HVL in subducted plate \\
3 & 100 & 100 & 0.05 & 0.001 & 7.6 & mafic HVL in subducted plate \\
4 & 7 & 7 & 0.0 & 0.0016 & - & Tertiary volcanic and sedimentary rocks \\
5 & 3 & 14 & 0.0 & 0.004 & - & Cretaceous volcanic rocks \\
6 & 60 & 60 & 0.0 & 0.0019 & - & serpentinized(?) mafic rocks \\
7 & 60 & 60 & 0.25 & 0.0014 & $6.8-7.1$ & mafic rocks \\
8 & 40 & 60 & 0.0 & 0.0012 & 5.7 & serp(?) mafic LVL; base of Ct and Pt \\
9 & 25 & 60 & 0.13 & 0.0 & 5.8 & subunit of Border Ranges mafic-ultram afic unit \\
$* 10$ & 40 & 60 & 0.14 & 0.0025 & $6.1-6.4$ & Border Ranges mafic-ultramafic unit, Pt basement \\
11 & 25 & 60 & 0.11 & 0.0 & $4.6 ?$ & Talkeetna Formation \\
12 & 25 & 60 & -0.37 & 0.0 & $2.0-4.6$ & CRB sedimentary rocks \\
$* 13$ & 15 & 3 & 0.23 & 0.0031 & - & um intrusion in Pt basement \\
\hline
\end{tabular}

*Body 13 is set within body 10 . Bodies 10 and 13 extend northward to $130 \mathrm{~km}$ on the distance scale. 
Middleton Island quadrangles, southern Alaska: U.S. Geological Survey Open-File Report 81-1164, scale 1:250,000.

Reviewers: J.E. Case and W.J. Nokleberg

\section{BEDROCK MAPPING OF REMOTE AREAS USING MEDIAL MORAINE DEBRIS FROM ACTIVE GLACIERS, MT. HAYES AND HEALY QUADRANGLES}

\section{Edward B. Evenson, George C. Stephens, and David E. Detra}

A four-year investigation of the use of supraglacial (medial moraine) debris as a tool for mineral exploration and bedrock mapping was completed in 1984. The primary objective of this study was to test the hypothesis of Evenson and others (1979), which stated that debris-in-transit in medial moraines could be used to conduct mineral exploration and reconnaissance bedrock mapping in remote, inaccessible, actively glaciated, mountainous areas. A second objective was to develop and refine the most economical, accurate, and expedient sampling method and to test its reliability and reproducibility. Preliminary results from this study have been reported by Evenson and others $(1981,1983,1984 \mathrm{a}$, 1984b), Stephens and others (1981, 1983), and Evenson and Stephens (1978).

In the winter of 1982-83, lithologic data collected during the summers of 1980-82 were used to prepare a moraine-based geologic map of the Trident-Susitna-Hayes-McGinnis eatchment area. This map was prepared using data on boulder, cobble, and pebble lithology in conjunction with air photo analysis. From this data base, we identified and mapped the distribution of five distinct lithologic units: (1) younger non-foliated granite; (2) phyllite and schist; (3) gabbro and leucogabbro; (4) gneiss; and (5) marble with interbedded phyllite. In addition, such criteria as fold style, cross-cutting relationship, type of igneous contact and planar features (joints, small faults, veins, etc.) were utilized to delineate the style and orientation of major structures (Evenson and others, 1984b). The orientations of major lithologic contacts and foliation patterns were added from air photo interpretation and logical extrapolation of rock type from valley to valley. The resultant moraine-based geologic map indicated that the catchment area of Trident Glacier is composed of well-foliated, isoclinally folded, east-west trending schist and phyllite with minor interlayered quartzite and marble, discordantly intruded by one granitic and one gabbroic igneous body (Evenson and others, 1984b). The Susitna catchment area, although composed of similar lithologies, has significantly more marble, including an area dominated by white, coarsely crystalline marble of approximately $16 \mathrm{sq}$ $\mathrm{km}$ located approximately $4 \mathrm{~km}$ south of $\mathrm{Mt}$.
Hayes. The high catchment areas of Hayes and McGinnis Glaciers are composed of a mixture of the above lithologies, while the lower areas of these two glacial systems are composed almost entirely of metasedimentary rocks (i.e., schist, phyllite, and quartzite). After extensive reconnaissance field checking in 1984, we determined that this method of producing a moraine-based geologic $\mathrm{m}$ ap is accurate.

During the 1980-83 field seasons, we collected fine-grained samples from each moraine in the glacial catchment system for geochemical analysis. The nonmagnetic heavy-mineral fraction of each sample was analyzed by a 31-element semiquantitative emission spectrographic technique, with 151 samples analyzed from Trident, Susitna, Hayes, and McGinnis Glaciers. Anomalous elemental values are chosen on the following basis: a first-order anomaly contains the highest two percent of the total population; a second-order anomaly contains the highest five percent of the total population. The location of anomalous values and the fine-grained sample geochemistry corresponds to the geology of the catchment area.

In order to test the reliability of our sampling technique, a study was undertaken along a litrologically diverse moraine in the Trident Glacier system. At five sites $100 \mathrm{~m}$ apart, five geochemical samples, and 50 pebbles were collected, and five cobble- and boulder-counts were performed. Thus, a total of 25 geochemical samples and corresponding pebble, cobble, and boulder counts were included. Due to the small geochemical sample size and the small number of pebbles, cobbles, and bculders counted at each site, considerable site-to-site variability exists, but is less than the average mcraineto-moraine variability. Our preliminary results indicate that the reproducibility of data on any given moraine is good, and site-to-site variability can be reduced by increasing the number and size of geochemical samples and the number of pebbles, cobbles, and boulders counted.

Preliminary results of this four-year project show that a rapid, efficient, and accurate technique for reconnaissance bedrock mapping in high, mountainous, alpine-glaciated regions has been doveloped.

\section{REFERENCES CITED}

Evenson, E. B., Clinch, J. M., Wagner, A. J., and Stephens, G. C., 1984a, The relative importance of debris transport mechanisms at active glacier margins in Alaska and applic tions to New England (abs.): Geological Society of America Abstract with Programs, v. 16, no. 1 , p. 15.

Evenson, E. B., Pasquini, T. A., Stewart, R. A., and Stephens, G. C., 1979, Systematic provenance investigations in areas of alpine glaciation: Applications to Glacial Geology and Mineral Exploration, in Schluchter, Ch. (ed.), Varves 
and Moraines, Rotterdam, A. Balkema Publishers, Nether lands, p. 25-42.

Evenson, E. B., Stephens, G. C., Curtin, G. C., and Tripp, R. B., 1981, Geochemical exploration using englacial debris: U.S. Geological Survey Circular 844, p. 297-300.

Evenson, E. B., Stephens, G. C., Neher, F. R., King, H. D., and Detra, D. E., 1984b, Mineral exploration and reconnaissance bedrock mapping using active alpine glaciers, Mount Hayes and Healy quadrangles, southern Alaska, in Coonrad, W. L., and Elliott, R. L., eds., The United States Geological Survey in Alaska: Accomplishments during 1981: U.S. Geological Survey Circular 868, p. 94-97.

Evenson, E. B., and Stephens, G. C., 1978, Till provenance studies in the Pioneer Mountains, Idaho, with application to mineral exploration in areas of alpine glaciation (abs.): Abstracts with Programs, Geological Society of America and Geologic Society of Canada Joint Annual Meeting-Toronto, v. 10, no. 7, p. 398.

Evenson, E. B., Stephens, G. C., Tripp, R. B., and Detra, D. E., 1983, Active alpine glaciers as a tool for bedrock mapping and mineral exploration- A case study in Alaska (No. 25785) (abs.): Geological Society of America Abstracts with Programs, v. 15, no. 5, p. 400.

Stephens, G. C., Evenson, E. B., Tripp, R. B., and Detra, D. E., 1981, Active alpine glaciers as a tool for bedrock mapping and mineral exploration- A case study from Trident Glacier, Alaska: INQUA Commission on the Genesis and Lithology of Quaternary Deposits Guidebook and Abstracts, 1981, p. 12.

Stephens, G. C., Evenson, E. B., Tripp, R. B., and Detra, D. E., 1983, Active alpine glaciers as a tool for bedrock mapping and mineral exploration- A case study from Trident Glacier, Alaska: in Evenson, E. B., Schluchter, Ch., and Rabassa, Jorge (eds.), Tills and Related Deposits: Genesis/Petrology; Application/Stratigraphy, Rotterdam, A. Balkema Publishers, p. 195-204.

Reviewers: J. B. Cathrall and H. D. King

\section{PRELIMINARY RESULTS OF TACT 1984 SEISMIC-REFRACTION SURVEY OF SOUTHERN ALASKA}

\section{Gary S. Fuis, Elizabeth L. Ambos, Walter D. Mooney, Robert A. Page, and David L. Campbell}

In the first field season (1984) of the TransAlaska Crustal Transect (TACT) program (see also Plafker and Nokleberg, 1985), we collected about $500 \mathrm{~km}$ of seismic-refraction data in southern Alaska. We designed the survey to outline, in 3 dimensions, the crustal structure within, and bounda-

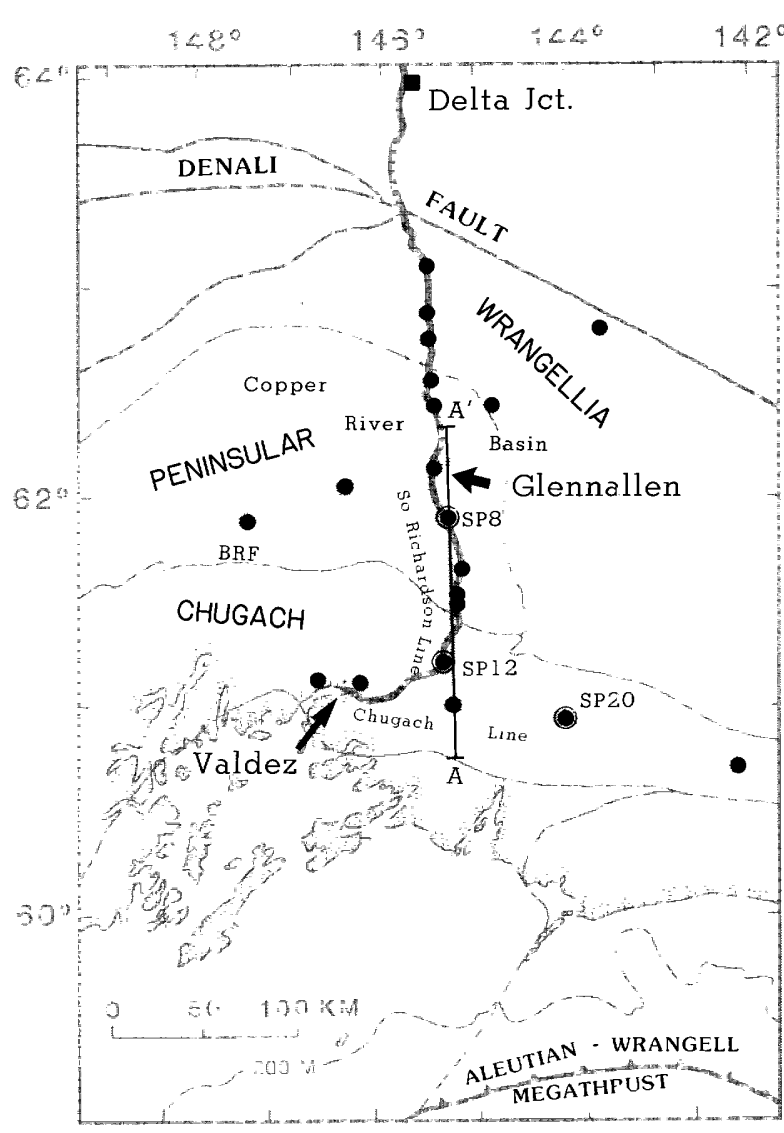

Figure 38.--Index map of southern Alaska showing location of terranes (Chugach, Peninsular, and Wrangellia) and seismic-refraction survey line. Shaded strips indicate instrument deployments; solid circles are shot points. Data for shot points 8 and 20 (SP8 and SP20) are shown in figures 41 and 39. $\mathrm{BRF}$, Border Ranges fault. $\mathrm{AA}^{\prime}=$ profile modeled for gravity and magnetic features (Campbell and Barnes, 1985).

ries between, the Chugach, Peninsuler, and Wrangellia terranes. The survey consisted of 3 lines (fig. 38) comprising 4 deployments of 120 instruments each. Each line was approximately $140 \mathrm{~km}$ long, with offset shots extending the lines to as much as $240 \mathrm{~km}$. Instruments were spaced approximately $1 \mathrm{~km}$ apart, and shots were spaced $\varepsilon \mathrm{n}$ average of $25 \mathrm{~km}$ apart on N-S lines across the structural grain and an average of $50 \mathrm{~km}$ apart on $\mathrm{E}-\mathrm{W}$ lines parallel to the structural grain. In practice, lines as long as $240 \mathrm{~km}$ can resolve velocity structure to depths of $30-50 \mathrm{~km}$. We used USGS cassette seismic recorders (Healy and others, 1982), each containing a 2$\mathrm{Hz}$ seismometer, 3 pre-set amplifiers, and a programmable memory controlling turn-on and turn-off times. Shots generally consisted of $590 \mathrm{~kg}$ of ammonium nitrate placed in drilled holes $(50 \times 0.15 \mathrm{~m})$ 

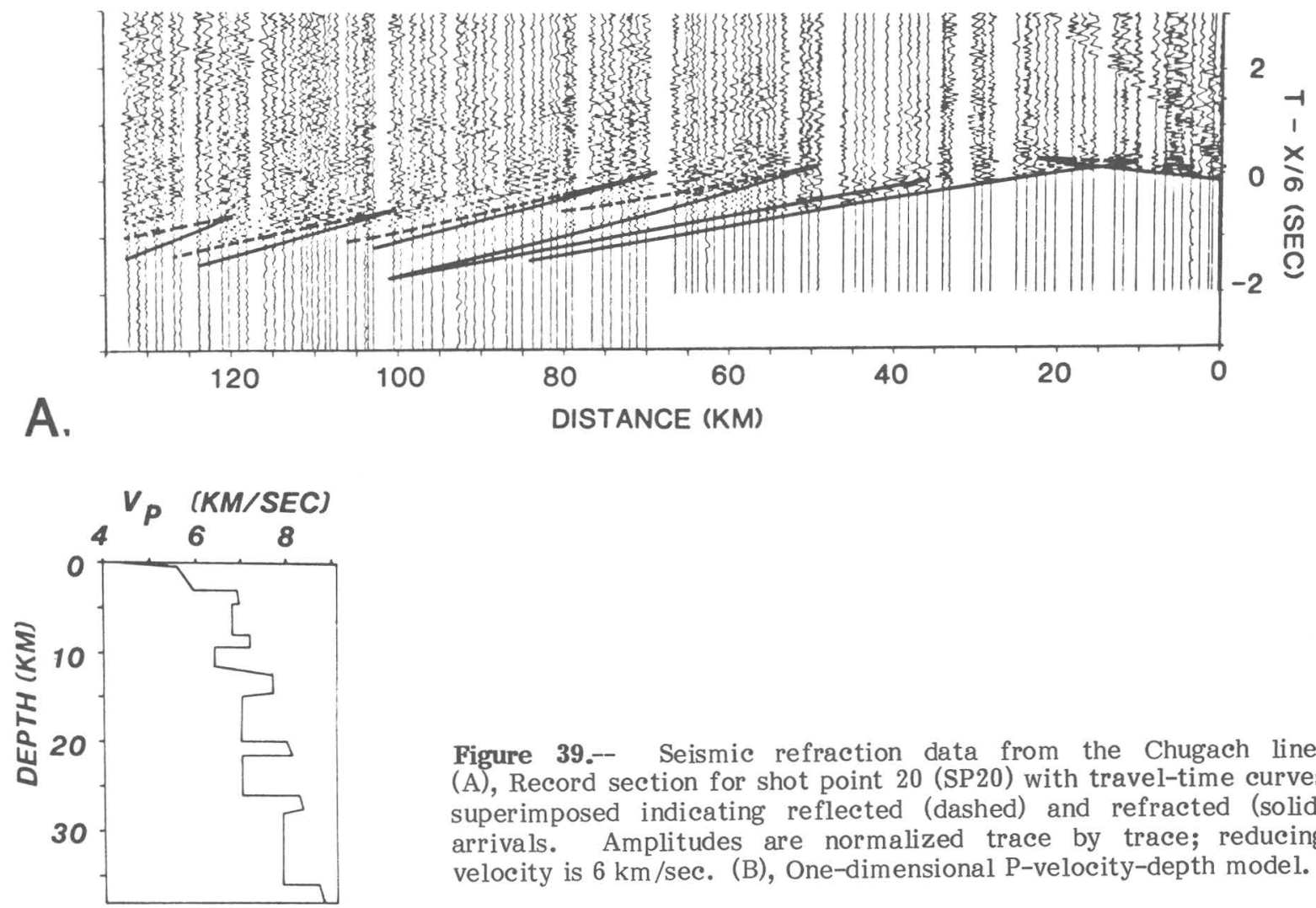

Figure 39.-- Seismic refraction data from the Chugach line. (A), Record section for shot point 20 (SP20) with travel-time curves superimposed indicating reflected (dashed) and refracted (solid) arrivals. Amplitudes are normalized trace by trace; reducing velocity is $6 \mathrm{~km} / \mathrm{sec}$. (B), One-dimensional P-velocity-depth model.

along roads or in lakes (15-20 m deep) along offroad segments of deployments. Offset shots were 2-3 times larger.

We present here preliminary velocity modeling and geologic interpretation of data from two abutting profiles, the Chugach line and the South Richardson line (fig. 38). The Chugach line was oriented $\mathrm{E}-\mathrm{W}$ at the latitude of Valdez, within the Chugach terrane. Recorders were deployed by helicopter along river valleys in the Chugach Mountains, and shots were detonated in lakes. The South Richardson line extended south from the vicinity of Glennallen to the Chugach line. It crossed the Copper River Basin, beneath which are buried the Peninsular and Wrangellia terranes, and the northern Chugach Mountains, underlain by the Chugach terrane. This line was deployed along the Richardson Highway, paralleling the trans-Alaska oil pipeline, except for the southern $25 \mathrm{~km}$, which was deployed by helicopter.

Data from the Chugach line are grossly similar from shotpoint to shotpoint implying little lateral velocity change. Data from shotpoint 20 , for example, are characterized by a short $(15-\mathrm{km}) 5.5-$ $\mathrm{km} / \mathrm{s}$ branch of arrivals, long (65-km) 6.9-and 7.1$\mathrm{km} / \mathrm{s}$ branches, and a prominent series of reflected and refracted arrivals with cusps, or critical reflections, at 50,70, 100, and $120 \mathrm{~km}$ (fig. 39A). (Note that velocities quoted are modeled refractor velocities and not necessarily apparent velocities.) Refracted branches in the latter series have velocities of $7.6 \mathrm{~km} / \mathrm{s}$ and greater. Shadow zones are seen (where refracted branches die out and are offset in time from succeeding reflected branches), indicating the presence of low-velocity zones (fig. 40). The one-dimensional structure determined from data for shotpoint 20 indicates a thin $(3-\mathrm{km})$ layer with a velocity of $5.5 \mathrm{~km} / \mathrm{s}$, and thick $(6-\mathrm{km})$ layer with a velocity of $6.8-7.1 \mathrm{~km} / \mathrm{s}$ (with one minor internal low-velocity zone), and a series of major low-velocity zones alternating with layers having velocities of $7.6 \mathrm{~km} / \mathrm{s}$ and greater (fig. $39 \mathrm{~B}$ ).

Data for the South Richardson line differ from shotpoint to shotpoint implying strong lateral velocity changes. The data from shotpoint 8 (fig. 41A) in the Copper River Basin show low velocities (2.0$4.9 \mathrm{~km} / \mathrm{s}$ ) corresponding to sedimentary and voleanic units in the basin, and a long $(35-\mathrm{km}) 5.9-\mathrm{km} / \mathrm{s}$ 

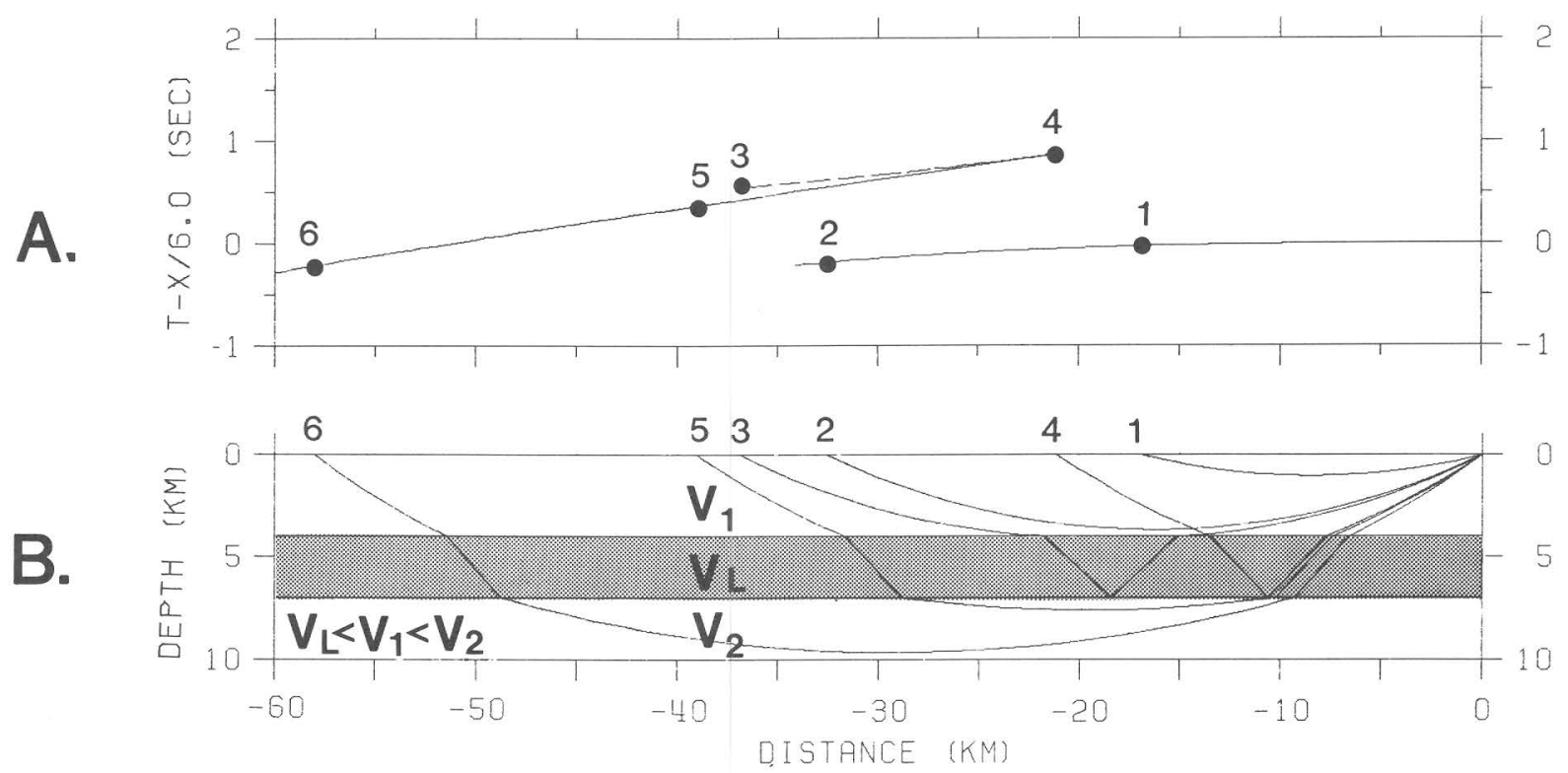

Figure 40.--Tutorial model of arrivals associated with a low-velocity zone. (A), Hypothetical travel-time curve. (B), Hypothetical model with low-velocity zone (LVZ). Ray paths are shown in model for certain arrivals and are numbered in order of decreasing takeoff angle (angle measured from downward vertical): rays 1 and 6-refractions in layers above and below LVZ, respectively; ray 2-last ray in upper layer unaffected by LVZ; ray 3 -first ray diverted into LVZ; ray 4-critical reflection from base of LVZ; ray 5- refraction in layer below LVZ. Shadow zone and travel-time delay are seen beyond arrival of ray 2 . This pattern is repeated five times in figure $39 \mathrm{a}$, but in the first instance, reflection and refraction from base of LVZ are indistinguishable and are shown with solid line in distance range $40-100 \mathrm{~km}$.

branch with early arrivals over the Tonsina maficultramafic body (Jmp, fig. 41B) at the south edge of the Peninsular terrane. Like the Chugach line, this line shows at least two prominent pairs of reflection and refraction branches that are offset from the $5.9-\mathrm{km} / \mathrm{s}$ branch and from each other. The layers generating these branches have velocities of 6.45 and $7.6 \mathrm{~km} / \mathrm{s}$. It is important to note that reflections from the $6.45-\mathrm{km} / \mathrm{s}$ layer have bottoming points beneath the Tonsina mafic-ultramafic body and the north part of the Chugach terrane, indicating that this layer cuts across the deep projection of the Border Ranges fault, the boundary between the Chugach and Peninsular-Wrangellia (composite) terranes (fig. 38). The two-dimensional model for the South Richardson line (fig. 41B) has been constrained by data from 7 shotpoints and by modeling of aeromagnetic and gravity data that were of importance in determining the shape of both the Tonsina mafic-ultramafic body (Jmp) and the wedge of $6.8-7.1-\mathrm{km} / \mathrm{s}$ material $(\mathrm{Kmp})$ at the southern end of the line. The Peninsular-Wrangellia (composite) terrane, located beneath the lowvelocity rocks of the Copper River Basin, is characterized by a $5.9-\mathrm{km} / \mathrm{s}$ basement overlying a $6.1-6.4-\mathrm{km} / \mathrm{s}$ body which corresponds to the Tonsina mafic-ultramafic body. The Peninsular-Wrangellia (composite) terrane is underlain by a low-velocity zone with a base at about $9 \mathrm{~km}$ depth, below which velocity increases to $6.45 \mathrm{~km} / \mathrm{s}$. The Chugach terrane is similar in that a $5.5-5.9 \mathrm{~km} / \mathrm{s}$ basement overlies a $6.8-7.1-\mathrm{km} / \mathrm{s}$ mafic/ultramafic complex in the southern part of the terrane. Furthermore, a low-velocity zone with a base at about $9 \mathrm{~km}$ depth underlies most of the terrane, and velocities of $6.45-7.1 \mathrm{~km} / \mathrm{s}$ are found below it. A major lowvelocity zone overlies a $7.6-\mathrm{km} / \mathrm{s}$ layer, that dips northward about 4 degrees. The dip changes to about 13 degrees near the northern edge of the Chugach terrane. The $6.45-\mathrm{km} / \mathrm{s}$ and $7.6-\mathrm{km} / \mathrm{s}$ layers, together with their overlying low-velocity zones, cut across the deep projection of the Border Ranges fault dividing the Peninsular-Wrangellia (composite) and Chugach terranes. The preliminary geologic and tectonic interpretation superimposed on the velocity model (fig. 41B) shows the Chugach and Peninsular-Wrangellia (composite) terranes uplifted on southward-verging thrust faults that flatten to the north into the uppermost low-velocity zone. The mafic-ultramafic bodies in the lower parts of each terrane are exposed (Jmp, fig. 41B) or nearly exposed (Kmp, fig. 41B) on the southern sides of the terranes. These terranes have apparently moved relatively southward over a lower crust of 


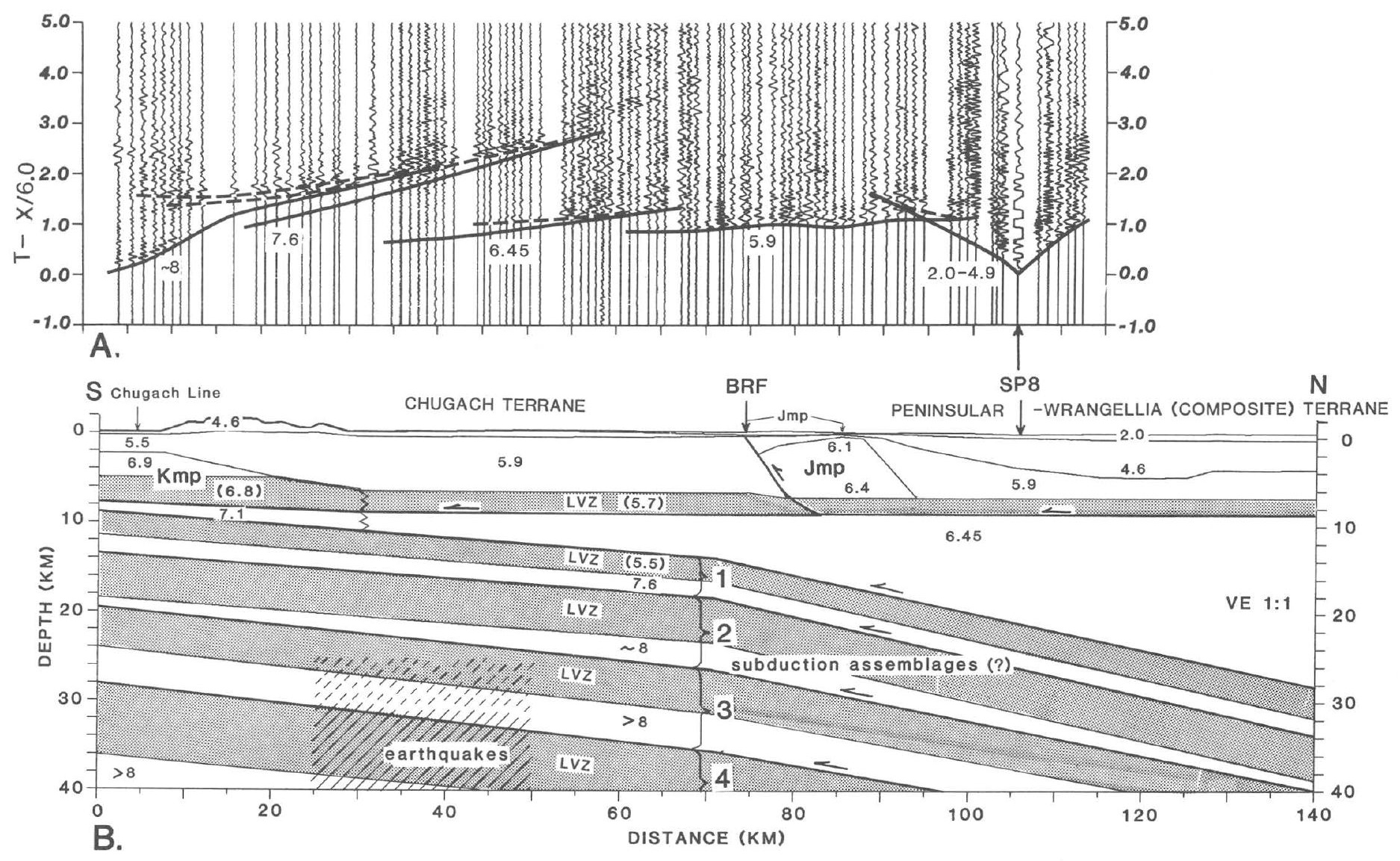

Figure 41.--Seismic refraction data from the South Richardson line. (A), Record section for shot point 8 and travel-time curve (see fig. 39). Numbers, in $\mathrm{km} / \mathrm{s}$, are model layer velocities. (B), Two-dimensional velocity model. Numbers, in $\mathrm{km} / \mathrm{s}$, are velocities. Low-velocity zones (LVZ's) are shaded. Region of earthquake occurrence is diagonally lined; dashed where controlled by only one earthquake. Geologic and tectonic interpretation is superimposed (see text). Heavy lines are faults, with arrows showing sense of displacement. Jmp, Kmp; Jurassic and Cretaceous mafic-ultramafic plutonic bodies, respectively. Unit Jmp crops out, and is called the Tonsina mafic-ultramafic body. BRF, Border Ranges fault separating the Chugach and Peninsular-Wrangellia (composite) terranes.

unknown, but possibly oceanic, origin. Subduction assemblages may be represented by layers with velocities of $7.6 \mathrm{~km} / \mathrm{s}$ and greater (oceanic mantle rocks), and overlying low-velocity zones (oceanic crust). At least four such assemblages may be present. The Wrangell Benioff zone is about $25-40 \mathrm{~km}$ deep in the vicinity of shot point 12 (SP12, fig. 41B), based on earthquake depths (Stephens and others, 1984), and may be associated with the lower two inferred assemblages. The upper two assemblages may lie above the currently active subduction megathrust and be subjoined to the upper, or continental, plate.

\section{REFERENCES CITED}

Campbell, D. L., and Barnes, D. F., 1985, Gravity and magnetic model of a part of the 1984 TACT line in the Chugach Mountains and southern Copper River Basin, in BartschWinkler, Susan (ed.), The United States Geological Survey in AlaskaAccomplishments During 1984: U.S. Geological Survey Circular 967, this volume.

Healy, J. H., Mooney, W. D., Blank, H. R., Gettings, M. E., Kohler, W. M., Lamson, Ralph, and Leone, L. E., 1982, Saudi Arabian seismic 
deep-refraction profile: Final project report: U.S. Geological Survey Saudi Arabian Mission Open-File Report 02-37, 429 p.

Plafker, George, and Nokleberg, W. J., 1985, Preliminary geologic results of the 1984 TACT program, in Bartsch-Winkler, Susan, (ed.), The United States Geological Survey in AlaskaAccomplishments During 1984: U.S. Geological Survey Circular 967, this volume.

Stephens, C. D., Fogleman, K. A., Lahr, J. C., and Page, R. A., 1984, Wrangell Benioff zone, southern Alaska: Geology, v. 12, p. 373-376.

Reviewers: H. M. Iyer, J. H. Luetgert

\section{PALEOMAGNETISM OF SEDIMENTARY ROCKS PRINCE WILLIAM AND YAKUTAT TERRANES}

\section{John W. Hillhouse and C. Sherman Gromme}

Early Tertiary sedimentary rocks were the subject of a paleomagnetic survey along the Gulf of Alaska from Hinchinbrook Island eastward to Cape Yakataga. Oriented samples were collected from the Orca Group of Paleocene and Eocene(?) age in an attempt to determine the original paleolatitude of the Prince William terrane (Jones and others, 1984). There is reason to suspect that the Orca Group has moved northward relative to cratonic North America, because paleomagnetic data from the early Tertiary Ghost Rocks Formation, which is considered part of the Prince William terrane on Kodiak Island, indicate $2,000 \mathrm{~km}$ of northward displacement since Paleocene time (Plumley and others, 1983). We also sampled Eocene and Oligocene sedimentary rocks within the Yakutat terrane (previously referred to as the Yakutat block), which is currently part of the Pacific plate (Plafker and others, 1978). Estimates of the total northward displacement of the Yakutat terrane vary from 2,000 km based on paleontology (Bruns, 1983), to about $550 \mathrm{~km}$ based on geologic data (Plafker; 1983, 1984).

We collected samples for paleomagnetic study from well-indurated siltstone layers within turbidite sequences of the Orca Group. These lithofeldspathic sedimentary deposits were derived from predominantly volcanic sources and were deposited as part of a deep-sea fan (Winkler, 1976; Winkler and others, 1976). The Orca Group has undergone complex deformation and metamorphism to laumontite and prehnite-pumpellyite facies. Our samples are from two sites on Hinchinbrook Island, Point Martin near Katalla, and Orea Inlet near Cordova (localities 1-4; fig. 42). The four sites are represented by a total of 114 independently oriented specimens. The natural remanent magnetizations (NRM) of the specimens are very weak $\left(10^{-7}\right.$ to $10-^{6}$ $\mathrm{emu} / \mathrm{cm}^{3}$ ) and the NRM field directions are poorly grouped. Approximately 15 percent of the specimens were treated to remove unstable components of magnetization by using the alternating field (AF) method to 1,000 Oersteds and then heating companion specimens in field-free space to $600^{\circ} \mathrm{C}$. Both $\mathrm{AF}$ and thermal demagnetization treatments failed to isolate stable magnetic directions, as the remanence exhibited erratic directional changes above 200 Oersteds and $250^{\circ} \mathrm{C}$. Treatments below these values revealed poorly defined downward directions, indicating that the rocks were magnetized by the modern geomagnetic field long after the rocks were deformed. The Orca sedimentary rocks apparently do not preserve magnetizations of detrital origin, so a tectonic interpretation cannot be made from the paleomagnetic data.

Lower Tertiary sedimentary rocks of the Yakutat terrane were collected from the Paleocene to Oligocene Kulthieth and upper Eocene to lower Miocene Poul Creek Formations (localities 5-10; fig. 42). Arkosic sandstone and siltstone (middle Eocene) were sampled from the lower part of the type section of the Kulthieth near Kulthieth Lake (17 specimens). The upper part (Eocene and Oligocene) of the Kulthieth Formation was sampled near Watson Glacier (36 specimens). In the study area near Yakataga, the Kulthieth Formation consists of shallow marine and continental sedimentary rocks with abundant coal (Plafker, 1971: Winkler and others, 1976). We also collected 156 specimens from the overlying Poul Creek Formation on Wingham Island, at Yakataga Glacier, and at two sites at Watson Glacier. The Poul Creek

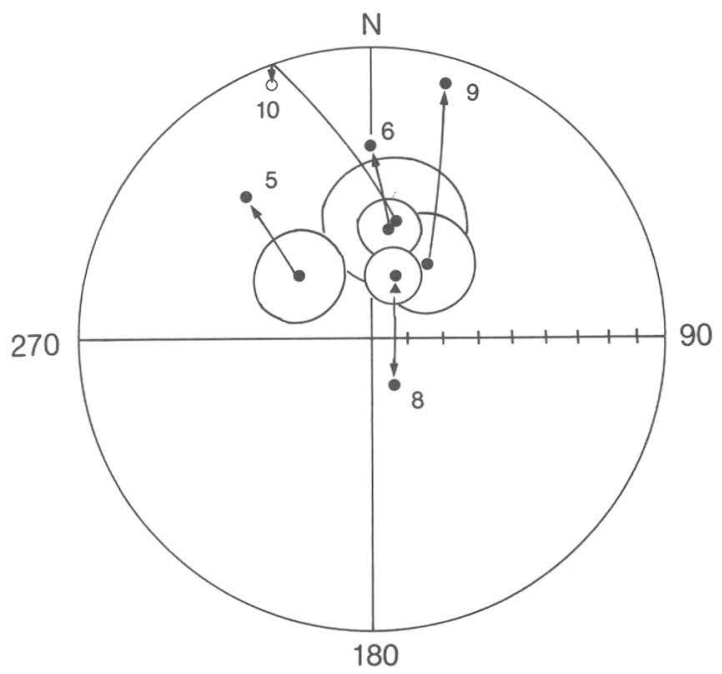

Figure 43.--Equal-area plot of mean magnetic field directions (with 95 percent confidence circles) after AF treatment of pilot specimens from the Yakutat terrane. Arrows indicate changes in directions caused by correcting for tilt of the bedding. Sites numbered as in figure 42 , with site 7 omitted due to its unacceptably large confidence limit. Triangle denotes present geomagnetic field direction in study area. 


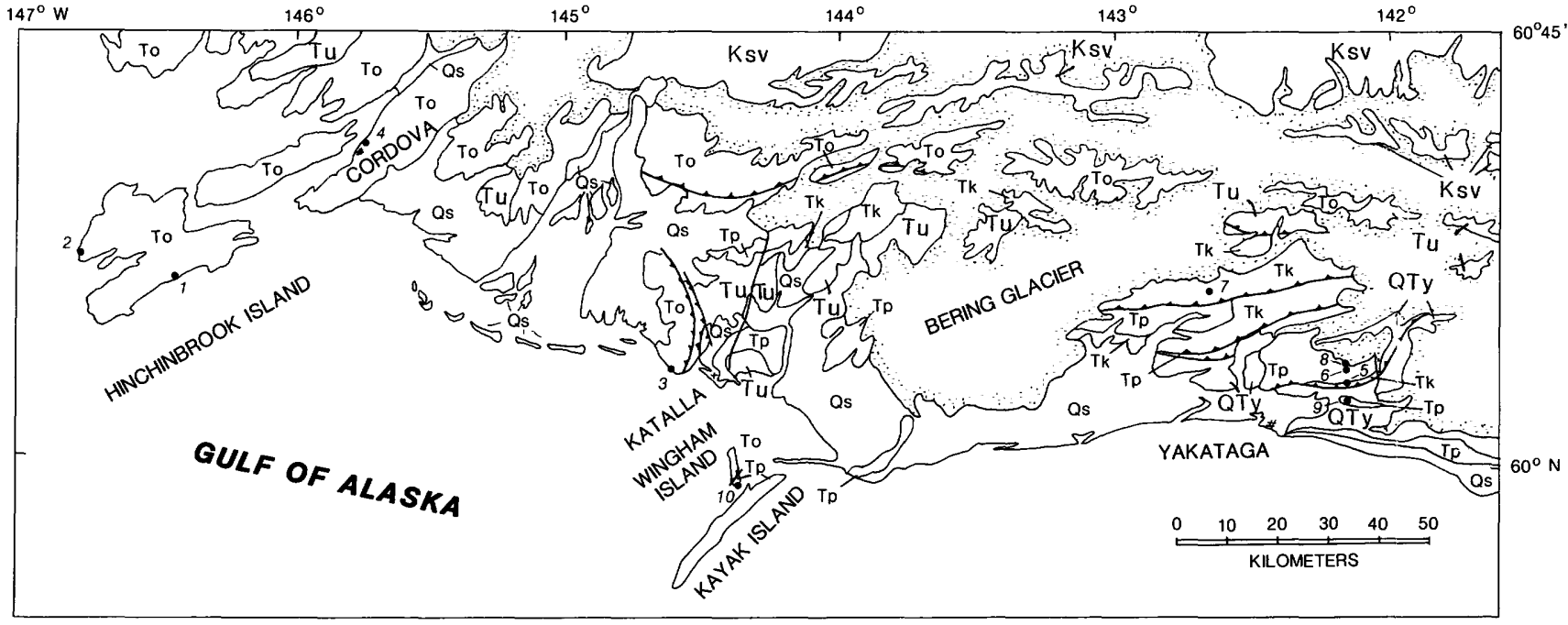

Figure 42.--Geologic map of the study area (modified from Plafker, 1967). Paleomagnetic sample localities: 1-4, Orca Group; 5, Kulthieth Formation at Watson Glacier; 6,8, Poul Creok Formation at Watson Glacier; 7, Kulthieth Formation at Kulthieth Lake type section; 9, Poul Creek Formation at Yakataga Glacier; 10, Poul Creek Formation at Wingham Island. Key to geologic symbols: Qs, surficial deposits (Quaternary); QTy, Yakataga Formation (Quaternary and Tertiary); Tp, Poul Creek Formation (Tertiary); Tk, Kulthieth Formation (Tertiary); ru, sedimentary rocks, undivided (Tertiary); To, Orca Group (Tertiary); Ksv, sedimentary and volcanic rocks (Cretaceous).

is marine siltstone and subordinate sandstone and, in general, is less deformed and indurated than the older Tertiary rocks of the region.

Like the Orca collection, pilot specimens from Kulthieth and Poul Creek collections were given AF and thermal demagnetization treatments in an attempt to remove unstable magnetic components. Typically, the weak NRM $\left(10^{-6} \mathrm{emu} / \mathrm{cm}^{3}\right)$ was reduced in intensity by 90 percent after being partially demagnetized in alternating fields of $200-300$ Oersteds, or after heating to $300^{\circ} \mathrm{C}$. Further demagnetization of the specimens in greater alternating fields or higher temperatures resulted in erratic changes in the magnetic directions. Both treatments isolated magnetic directions that were inclined steeply downward and toward the north before corrections for tilt of the bedding were applied. Results from the AF treatments are shown in figure 43. The angular dispersion of magnetic directions increased significantly when the bedding corrections were applied, indicating that the magnetization postdates folding of the strata. As we found in the Orca Group, the original detrital magnetizations of the Kulthieth and Poul Creek Formations are not preserved at our sampling localities. Therefore, we were unable to determine original paleolatitudes from Tertiary sedimentary rocks of either the Prince William or Yakutat terranes.

\section{REFERENCES CITED}

Bruns, T. R., 1983, Model for the origin of the Yakutat block, an accreting terrane in the northern Gulf of Alaska: Geology, v. 11, p. 718-721.

Jones, D. L., Silberling, N. J., Coney, P. J., and Plafker, George, 1984, Lithotectonic terrane map of Alaska, in Silberling, N. J. and Jones, D. L., eds., Lithotectonic terrane map of the North American Cordillera: U.S. Geslogical Survey Open-File Report 84-523, 12 p.

Plafker, George, 1967, Geologic map of the Gulf of Alaska Tertiary Province, Alaska, scale 1:500,000: U.S. Geological Survey Miscellaneous Geologic Investigations Map I-481.

Plafker, George, 1971, Possible future petroleum resources of Pacific margin Tertiary basin, Alaska, in Future Petroleum Provinces of North America: American Association of Petroleum Geologists Memoir 15, p.120-135.

Plafker, George, 1983, The Yakutat block: An actively accreting tectonostratigraplic terrane in southern Alaska (abs.): Geological Society of America Abstracts with Prngrams, v. 15, p. 406.

Plafker, George, 1984, Comments and replies on "Model for the origin of the Yakutat block, an accreting terrane in the northern Gulf of Alaska": Geology, v. 12, p. 563.

Plafker, George, Hudson, Travis, Bruns, T. R., and Rubin, Meyer, 1978, Late Quaternar? of fset along the Fairweather fault and crustal plate interactions in southern Alaska: Canadian Journal of Earth Sciences, v. 15, p. 805-816.

Plumley, P. W., Coe, R. S., and Byrne, Tim, 1983, Paleomagnetism of the Paleocene Ghost 
Rocks Formation, Prince William terrane, Alaska: Tectonics, v. 2, p. 295-314.

Winkler, G. R., 1976, Deep-sea fan deposition of the lower Tertiary Orca Group, eastern Prince William Sound, Alaska: U.S. Geological Survey Open-File Report 76-83, 20 p.

Winkler, G. R., McLean, Hugh, and Plafker, George, 1976, Textural and mineralogical study of sandstones from the onshore Gulf of Alaska Tertiary Province, southern Alaska: U.S. Geological Survey Open-File Report 76-198, 48 p.

Reviewers: E. A. Mankinen and George Plafker

\section{NEW EVIDENCE FOR ACTIVITY ON THE TALKEETNA SEGMENT, CASTLE MOUNTAIN-CARIBOU FAULT SYSTEM: THE 1984 SUTTON EARTHQUAKE}

\section{John C. Lahr, Robert A. Page, Kent A. Fogleman, and Christopher D. Stephens}

The Castle Mountain-Caribou fault system in southern Alaska extends about $200 \mathrm{~km}$ from the Susitna River ENE across the Susitna Lowland and the southern margin of the Talkeetna Mountains to the edge of the Copper River Basin (fig. 44). The fault system passes $40 \mathrm{~km}$ from Anchorage, $15 \mathrm{~km}$ from Palmer, and $10 \mathrm{~km}$ from Wasilla. Because of its proximity to the principal population center of Alaska, the seismic potential of the fault system is an important issue. Although future earthquakes as large as magnitude 7.25-8.5 $\left(\mathrm{M}_{\mathrm{S}}\right)$ have been postulated for the this fault system in various seismic hazard studies (Patwardhan and others, 1980; Thenhaus and others, 1985), there is considerable uncertainty regarding the length of the fault that is active, and the maximum size and rate of occurrence of future earthquakes.

The Castle Mountain-Caribou fault system is divided into two segments (Detterman and others, 1974); the western, or Susitna segment, and the eastern, or Talkeetna segment. Although the Susitna segment of the fault system has long been recognized as active on the basis of Holocene scarps (Detterman and others, 1974), definitive geologic or seismic evidence concerning the activity of the Talkeetna segment has been lacking (Detterman and others, 1976). The closest large historic earthquake to the fault system was a magnitude $7.0 \mathrm{M}_{\mathrm{s}}$ that occurred in 1933 with an epicenter located $16 \mathrm{~km}$ south of the Susitna trace. Within the uncertainty of the epicenter location, this event may have occurred on the fault.

On August 14, 1984, a magnitude $5.7 \mathrm{~m}_{\mathrm{b}}(5.2$ $M_{S}$ ) earthquake occurred $7 \mathrm{~km}$ north of Sutton in the vicinity of the mapped trace of the Talkeetna segment. No surface breakage was discovered in an aerial reconnaissance and ground inspection of the fault conducted two weeks after the earthquake (T. P. Miller, USGS, oral commun., August
29, 1984). Well-located hypocenters for 35 aftershocks (fig. 44, inset) occurring between August 14 and September 25 define a buried planar zone striking parallel to the mapped traco and dipping nearly vertically northward, with dimensions of $12 \mathrm{~km}$ along strike and $8 \mathrm{~km}$ down-dip. The most shallow of these events is located at $12 \mathrm{~km}$ depth; the absence of shallower events is consistent with the lack of observed surface breakage. The main shock is located at $20 \mathrm{~km}$ depth, near the depth of the deepest aftershocks. Within the uncertainty of the data, the main shock and aftershocks can be associated with a single, steeply north-dipping fault, consistent with the mapped trace of the Talkeetna segment.

The focal mechanism of the mrin shock was determined from $65 \mathrm{P}$-wave first motions, primarily at regional distances (fig. 44). The slip plane is inferred from the close correspondence between the ENE-striking nodal plane and the attitude of the aftershock zone. Thus, the earthquake involved dextral slip on the ENE nodal plane consistent with the sense of lateral Holocene offsets on the Susitna segment (Detterman and others, 1976).

The Sutton earthquake sequence supports the conjecture of previous authors (for example, Woodward-Clyde Consultants, 1980; Thenhaus and others, 1985) that the Talkeetna segment of the fault system is active. In addition, a re-examination of the locations of small earthquakes recorded since 1971 by the southern Alaska regional seismograph network suggests association of a few scattered earthquakes with that part of the Talkeetna segment west of the bifurcation of the Castle Mountain and Caribou faults. For tre purpose of hazard evaluation, therefore, at least $130 \mathrm{~km}$ of the Castle Mountain-Caribou fault system should be considered active, from the westernmo $t$ location of Holocene offset near the Susitna River to the bifurcation of the Caribou fault at about $148.5^{\circ} \mathrm{W}$. Considering the distribution of magnitude versus rupture length for previously studied earthquakes (Slemmons, 1977; Bonilla and others, 1984), we conclude that if this length of the fault were to rupture in one strike-slip event, the magnitude would be within the range 7.2 to $7.8 \mathrm{M}_{\mathrm{S}}$.

\section{REFERENCES CITED}

Bonilla, M. G., Mark, R. K., and Lienkaemper, J. J., 1984, Statistical relations among earthquake magnitude, surface rupture length, and surface fault displacement: Bulletir of the Seismological Society of America, v. 74, p. 23792411.

Detterman, R. L., Plafker, George, Hudson, Travis, Tysdal, R. G., and Pavoni, Nazar:o, 1974, Surface geology and Holocene breaks along the Susitna segment of the Castle Mountain fault, Alaska: U.S. Geological Survey Miscellaneous Field Studies Map MF-618, scale 1:24,000, 1 sheet. 


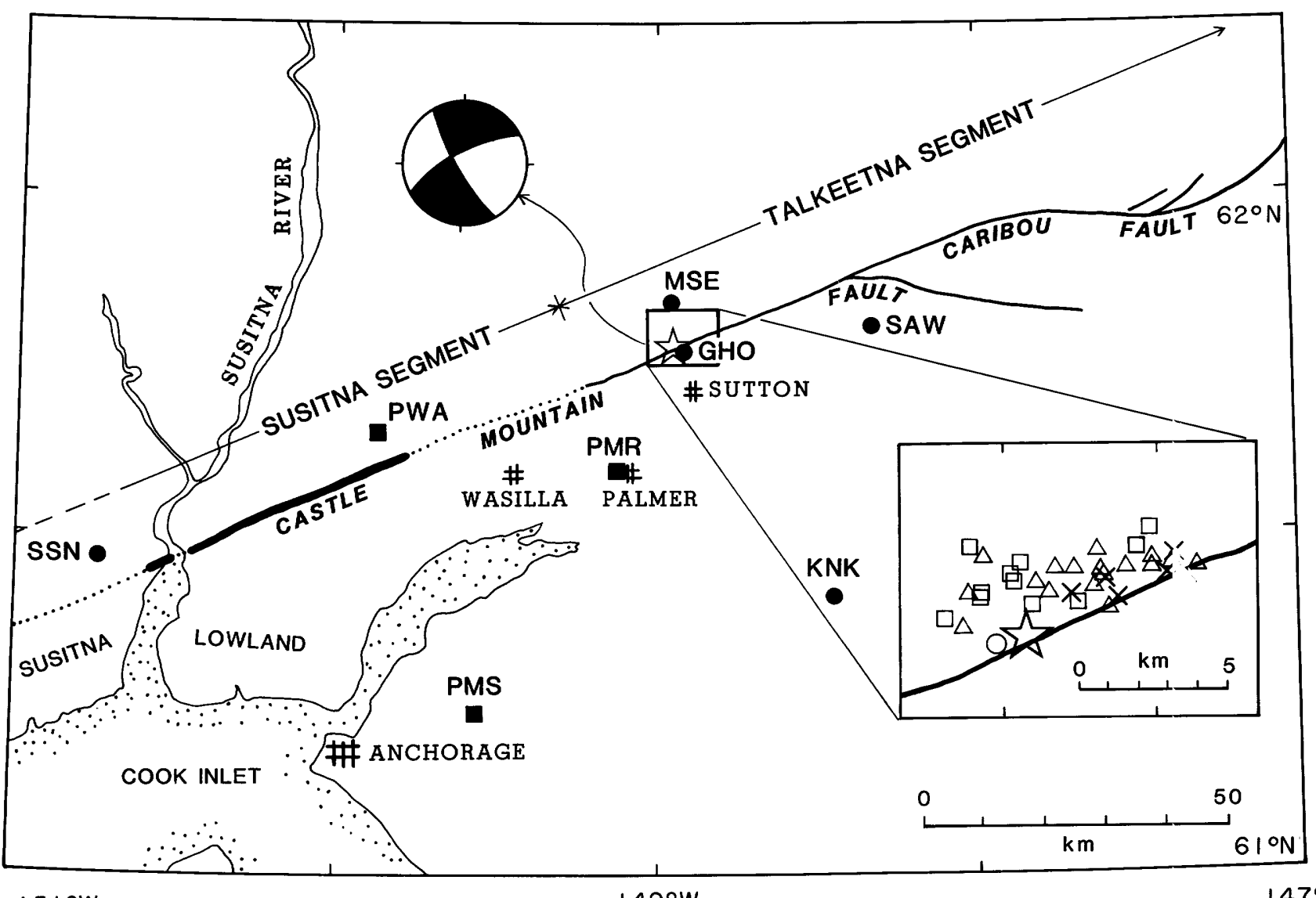

$151^{\circ} \mathrm{W}$

$149^{\circ} \mathrm{W}$

Figure 44.--Castle Mountain-Caribou fault system after Detterman and others (1976) and epicenter (star) of the 1984 Sutton earthquake. Heavy lines denote sections with Holocene breaks. Solid circles and squares indicate locations of USGS and Alaska Tsunami Warning Center seismograph stations. Focal mechanism solution (lower hemisphere) for main shock is shown; compressional first-motion quadrants are shaded. Inset shows epicenters of main shock (star) and 35 aftershocks with magnitudes as small as 1.0 in relation to fault trace. Symbols vary with depth: $X, 5.0-9.9$; triangle, 10.0-14.9; square, 15.0-19.9; and circle, 20.0-24.9. Stations GHO and MSE, which were not installed until 11 September 1984, were used to calibrate the velocity model for the Sutton region but were not used directly in the hypocenter determinations of the events shown.

Detterman, R. L., Plafker, George, Tysdal, R. G., and Hudson, Travis, 1976, Geology of surface features along part of the Talkeetna segment of the Castle Mountain-Caribou fault system, Alaska: U.S. Geological Survey Miscellaneous Field Studies Map MF-738, scale 1:63,360, 1 sheet.

Patwardhan, A. S., Idriss, I. M., Hobgood, J. M., Kulkarni, R. B., and Sadigh, K., 1980, Characterization of earthquake sources in the Gulf of Alaska: Marine Geotechnology, V. 4, p 243267.

Slemmons, D. B., 1977, State-of-the-art for assessing earthquake hazards in the United States, Report 6, Faults and earthquake magnitude: Mackay School of Mines, University of Nev-
ada-Reno, prepared for Office, Chief of Engineers, U.S. Army, Washington, D.C., 129 p.

Thenhaus, P. C., Ziony, J. I., Diment, W. H., Hopper, M. G., Perkins, D. M., Hans on, S. L., and Algermissen, S. T., 1985, Probabilistic estimates of maximum seismic acceleration in rock in Alaska and the adjacent outer continental shelf: Earthquake Spectra, v. 1, p. 285306.

Woodward-Clyde Consultants, 1980 , Interim report on seismic studies for Susitna hydrolectric project: unpublished report, Acres American Incorporated, Buffalo, New York, 194 p., 8 appendices.

Reviewers: R. L. Detterman and P. A. Reesenberg 


\section{PRELIMINARY INTERPRETATION OF FACTOR ANALYSIS OF \\ GEOCHEMICAL DATA FROM THE HEALY QUADRANGLE}

\section{by Thomas $\mathrm{D}$. Light}

A reconnaissance geochemical survey of the Healy quadrangle was conducted between 1980 and 1982 as part of the Alaska Mineral Resource Assessment Program (AMRAP). Stream-sediment samples were collected at 1,064 sites, and heavymineral concentrate samples were collected at 1,045 of these sites.

Stream-sediment samples and nonmagnetic fractions of the heavy-mineral concentrate samples were analyzed for 31 elements by semiquantitative emission spectrography. In addition, some of the stream-sediment samples were analyzed by atomic absorption for $\mathrm{As}, \mathrm{Au}, \mathrm{Cd}, \mathrm{Sb}$, and $\mathrm{Zn}$. Analytical data for the stream-sediment and heavy-mineral concentrate samples are reported in O'Leary and others (1984). Only elements containing at least 80 percent of their measured values within the analytical limits of determination were considered in this study.

A specific lithologic unit or mineral deposit type will exhibit a geochemical signature characterized by a distinct suite of trace elements. R-mode factor analysis with varimax rotation was used to define such geochemical associations in both the sediment and concentrate data sets. R-mode factor analysis (VanTrump and Miesch, 1976) was used to place similarly behaving variables (elements) into factors. Table 15 shows the factor loadings for those factors determined to be significant (eigenvalues greater than one) in both data bases. Plotting the distribution of samples with high factor scores (upper 5th percentile) for each of the factors allowed spatial interpretation of the geochemical associations.

Table 15 lists five significant factors derived from R-mode factor analysis of stream-sediment samples. Elements loading strongly intc factor 1S ( $\mathrm{Co}, \mathrm{Cu}, \mathrm{Ni}, \mathrm{Mg}, \mathrm{Fe}, \mathrm{V}, \mathrm{Cr}, \mathrm{Sc}$, and $\mathrm{Zn}$ ) define a mafic association derived from basaltic, diabasic and gabbroic rocks in the Chulitna district south of Lookout Mountain, in Paleozoic and Triassic sedimentary rocks of the Yukon-Tanana terrane, and in the Wrangellia terrane (fig. 45). Samples with the highest factor 1S scores define the Triassic Nikolai Greenstone in the Wrangellia terrane. Samples from the Upper Chulitna mining district (Chulitna and West Fork terranes of Jones and others, 1981) also load high in factor $1 \mathrm{~S}$, due to ultramafic rocks containing small nickel and chromium deposits, and precious and base metals occurring in vein, porphyry, and massive sulfide type deposits (Hawley and Clark, 1974; MacKevett and Holloway, 1977).

Factor 2S, with high loadings for Y, La, Be, $\mathrm{Pb}$, and $\mathrm{Zr}$, reflects a rare-earth lithophile enrich-

Table 15.--Varimax rotation factor loadings for stream-sediment (S) and heavy-mineral concentrate $(\mathrm{C})$ data. Loadings less than 0.40 have been omitted. aa, atomic absorption analysis; all other analyses by semiquantitative emission spectrography; NA, not applicable (less than 80 percent of values between limits of determination)

\begin{tabular}{|c|c|c|c|c|c|c|c|c|}
\hline Factor & $1 \mathrm{~S}$ & $2 \mathrm{~S}$ & $3 \mathrm{~S}$ & $4 \mathrm{~S}$ & $5 \mathrm{~S}$ & $1 \mathrm{C}$ & $2 \mathrm{C}$ & $3 \mathrm{C}$ \\
\hline $\mathrm{Fe}$ & 0.61 & - & 0.57 & - & - & 0.88 & - & - \\
\hline $\mathrm{Mg}$ & 0.61 & - & - & 0.43 & - & - & 0.88 & - \\
\hline $\mathrm{Ca}$ & - & - & 0.43 & 0.63 & - & - & 0.67 & - \\
\hline $\mathrm{Ti}$ & - & - & 0.72 & - & - & NA & NA & NA \\
\hline $\mathrm{Mn}$ & - & - & 0.68 & - & - & - & 0.77 & - \\
\hline B & - & - & - & - & - & - & 0.51 & - \\
\hline $\mathrm{Ba}$ & - & - & - & - & 0.92 & NA & NA & NA \\
\hline $\mathrm{Be}$ & - & 0.64 & - & - & - & NA & NA & NA \\
\hline Co & 0.85 & - & - & - & - & 0.86 & - & - \\
\hline $\mathrm{Cr}$ & 0.59 & - & - & - & - & - & 0.78 & - \\
\hline $\mathrm{Cu}$ & 0.85 & - & - & - & - & 0.83 & - & - \\
\hline $\mathrm{La}$ & - & 0.74 & - & - & - & - & - & 0.86 \\
\hline $\mathrm{Ni}$ & 0.82 & - & - & - & - & 0.87 & - & - \\
\hline $\mathrm{Pb}$ & - & 0.59 & - & - & - & 0.72 & - & - \\
\hline $\mathrm{Sc}$ & 0.54 & - & - & 0.61 & - & - & - & 0.68 \\
\hline $\mathrm{Sr}$ & - & - & - & 0.72 & - & - & - & - \\
\hline V & 0.60 & - & - & - & - & - & 0.82 & - \\
\hline $\mathbf{Y}$ & - & 0.77 & - & - & - & - & - & 0.86 \\
\hline $\mathrm{Zr}$ & - & 0.53 & 0.57 & - & - & NA & NA & NA \\
\hline Zn-aa & 0.48 & - & - & - & - & NA & NA & NA \\
\hline \multicolumn{9}{|c|}{ Eigenvalues before rotation: } \\
\hline & 5.84 & 2.81 & 2.41 & 1.31 & 1.01 & 5.24 & 2.48 & 2.12 \\
\hline
\end{tabular}




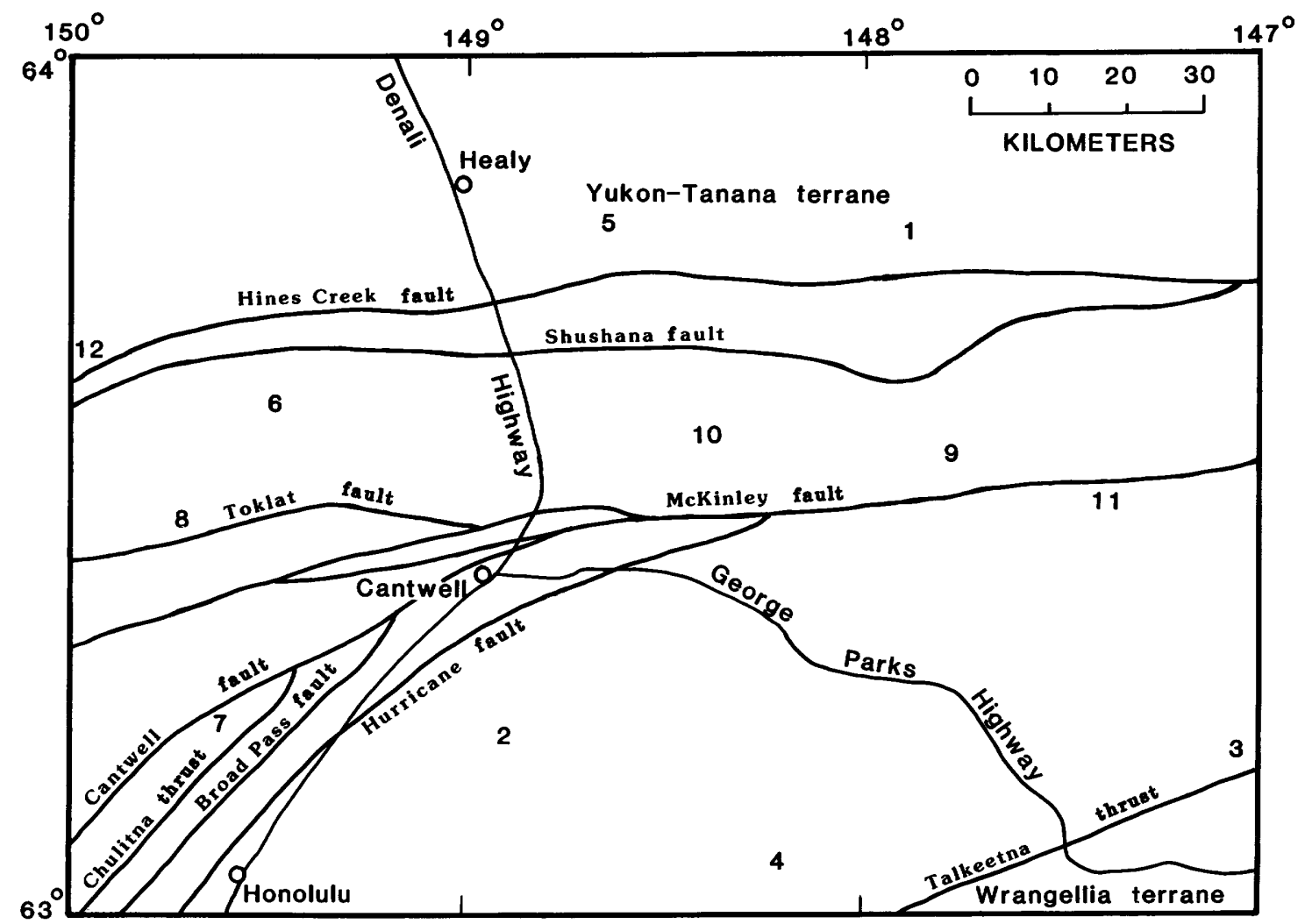

Figure 45.--Generalized tectonostratigraphic terrane map of the Healy quadrangle, after Jores and others (1981, 1983). 1, Anderson Mountain; 2, Caribou Pass; 3, Clearwater Mountains; 4, Deadman Mountain; 5, Dora Peak; 6, Double Mountain; 7, Lookout Mountain; 8, Mol'nt Pendleton; 9, Nenana Mountain; 10, Pyramid Peak; 11, West Fork Glacier; 12, Wyoming Hills.

ment associated with Tertiary felsic volcanic and granitic rocks. Samples with the highest varimax scores for this factor plot in the vicinity of Tertiary granitic and volcanic rocks that intrude upper Mesozoic flysch between Honolulu and Deadman Mountain and south of Caribou Pass. A few isolated samples with high scores for factor $2 \mathrm{~S}$ occur in areas of Tertiary granitic rocks in the west-central part of the quadrangle, and in sediments derived from a pelitic schist unit and in the Totatlanika Schist in the eastern half of the Yukon-Tanana terrane.

Plots of samples with high varimax scores for factor $3 \mathrm{~S}(\mathrm{Ti}, \mathrm{Mn}, \mathrm{Zr}, \mathrm{Fe}$, and $\mathrm{Ca}$ ) are concentrated to the east of Deadman Mountain in the southeast portion of the Healy quadrangle, where Cretaceous and Tertiary granites intrude Mesozoic flysch. The dense cluster of high factor scores may indicate a unique lithology in this area. Scattered sediments with high factor scores also occur in the Tertiary Nenana Gravel in the western Yukon-Tanana terrane.

Samples with high scores for elements loading strongly into factor $4 \mathrm{~S}(\mathrm{Sr}, \mathrm{Ca}, \mathrm{Sc}$, and $\mathrm{Mg}$ ) are con- centrated along the eastern edge of the quadrangle south of the McKinley fault, and reflect the distribution of sediments derived from calcareou: Triassic metasedimentary and Cretaceous granitic rocks in the vicinity of the West Fork Glacier and from Cretaceous granitic rocks in the rorthern Clearwater Mountains (fig. 45).

The distribution of samples showing high scores for factor $5 \mathrm{~S}$ is controlled mostly by anomalous barium. High scores in the Chulitna district are probably associated with hydrothermal mineralization described by Hawley and Clark (1974). Other areas of samples with high scores into fa?tor $5 \mathrm{~S}$ are: Tertiary granite in Wyoming Hills; Prleozoic siltstones and limestones west of Mount Pendleton, north of Nenana Mountain, and east of Anderson Mountain in the Yukon-Tanana terrane; and Tertiary coal-bearing units along the northern bourdary of the quadrangle.

Table 15 lists three significant factors derived from R-mode factor analysis of heavy-mineral concentrate data. Factor 1C shows strong loadings for elements related to both mafic rocks and hydrother- 
mal mineralization. The association of $\mathrm{Fe}, \mathrm{Ni}$, and Co reflects mafic and ultramafic lithologies near Lookout Mountain in the Chulitna district. These rocks are hosts for $\mathrm{Fe}-, \mathrm{Cu}-$, and $\mathrm{Pb}$-rich magmatic mineral deposits. Several samples with unexplained high scores plot along the western McKinley fault, and in a pelitic schist unit of the Yukon-Tanana terrane along the north flank of Dora Peak. Two isolated areas with anomalous factor 1C sample scores along the eastern McKinley fault may host mineralization related to a porphyry(?) system in the West Fork Glacier area (MacKevett and Holloway, 1977).

Factor 2C (high loadings for $\mathrm{Mg}, \mathrm{V}, \mathrm{Cr}, \mathrm{Mn}$, $\mathrm{Ca}$, and $\mathrm{B}$ ) represents a lithologic assemblage characterizing silicate minerals in the Mesozoic flysch and in the Cretaceous and Tertiary granitic and volcanic rocks. Samples with the highest scores for this factor are located east of Double Mountain where Mesozoic flysch and Tertiary volcanic rocks of mafic to intermediate composition occur in close proximity (Bela Csejtey, USGS, written commun., 1985). Areas containing samples with high factor scores also occur in the Tertiary Cantwell Formation southwest of Anderson Mountain, and in the Mesozoic flysch north of Lookout Mountain.

Factor $3 \mathrm{C}$ is dominated by a rare-earth association, similar to factor $2 \mathrm{~S}$, and relates to the Tertiary granitic and felsic volcanic rocks. Samples with the highest scores for this factor are derived from Tertiary granite at Pyramid Peak. Most other samples with high scores for this factor fall within the area of Tertiary granitic and volcanic rocks in the south-central part of the quadrangle, between Honolulu and Deadman Mountain.

Preliminary evaluation of geochemical data from the Healy quadrangle suggests that factor analysis can be used to help delineate both the distribution of stratigraphic units and the occurrence of mineral deposits. In addition, because tectonostratigraphic terranes are defined, in part, by a "distinctive stratigraphic sequence or rock assemblage " (Jones and others, 1981), factor analysis of reconnaissance geochemical data might be helpful in defining unique geochemical signatures for terranes that are chemically distinct.

\section{REFERENCES CITED}

Hawley, C. C., and Clark, A. L., 1974, Geology and mineral deposits of the Upper Chulitna district, Alaska: U.S. Geological Survey Professional Paper 758-B, $47 \mathrm{p}$.

Jones, D. L., Silberling, N. J., Berg, H. C., and Plafker, George, 1981, Map showing tectonostratigraphic terranes of Alaska, columnar sections, and summary description of terranes: U.S. Geological Survey Open-File Report 81-792, 20 p., scale 1:250,000.

Jones, D. L., Silberling, N. J., and Coney, P. J., 1983, Tectonostratigraphic map and interpretive bedrock geologic map of the Mount Me Kinley region, Alaska: U.S. Geological Sur- vey Open-File Report 83-11, scale 1:250,000.

MacKevett, E. M., and Holloway, C. D., 1977, Map showing metalliferous and selected nonmetalliferous mineral deposits in the eastern part of southern Alaska: U.S. Geolog:cal Survey Open-File Report 77-169A, 99 p., scale $1: 1,000,000$.

O'Leary, R. M., Hoffman, J. D., Sutley, S. J., and King, H. D., 1984, Analy tical results and sample locality map of stream-sediment and heavy-mineral concentrate samples from the Healy quadrangle, Alaska: U.S. Geological Survey Open-File Report 84-104, 151 p., scale $1: 250,000$.

VanTrump, George, Jr., and Miesch, A. T., 1976, The U.S. Geological Survey RASi-STATPAC for management and statistical reduction of geochemical data: Computers and Geosciences, v. 3, p. 475-488.

Reviewed by: R. J. Goldfarb and J. D. Hoffman

\section{SUMMARY OF STRATIGRAPHY, STRUCTURE, AND METAMORPHISM OF DEVONIAN IGNEOUS-ARC TERH ANES, NORTHEASTERN MOUNT HA!'ES QUADRANGLE, EASTERN ALASK $\uparrow$ RANGE}

\section{Warren J. Nokleberg and John N. AJ?inikoff}

The northeastern Mount Hayes quadrangle, north of the Mount Gakona fault, is composed, from north to south, of the Lake George, Macomb, and Jarvis Creek Glacier tectonostratigraphic terranes (fig. 46) (Nokleberg and others, 1983), which occur in the southern part of the Yukon-Tarana terrane (Jones and others, 1981). South of the Mount Gakona fault are the Hayes Glacier and Windy terranes (fig. 46). In the Mount Hayes quadrangle, the Hayes Glacier terrane includes the Pingston terrane (Jones and others, 1981; Nokleberg and others, 1983; 1984; Aleinikoff and Nokleberg, 1984b).

The Lake George terrane consists of a sequence of coarse-grained, multiply-deformed, pelitic, mylonitic schists intruded by Devonian schistose granodiorite (Aleinikoff and Nokleberg, 1985a). Mississippian augen gneiss derived from granitic plutonic rocks crops out to the north and east (Aleinikoff and others, 1981; Dusel-Bacon and Aleinikoff, 1985; J. N. Aleinikoff, Cynthia DuselBacon, and H. L. Foster, written commun., 1985). In a few areas, the schistose granodiorite intrudes and has inclusions of the pelitic schist. The metamorphosed plutonic rocks probably intruded these rocks at moderate to deep levels as indicated by the coarse grain size of relict igneous plagioclase, hornblende, biotite, and quartz, and by the homogeneity of individual plutons. The pelitic schists and metaplutonic rocks are mult:ply deformed and metamorphosed at conditions of the middle or upper amphibolite facies, with old?r, refolded schistosity and foliation transposed into younger 


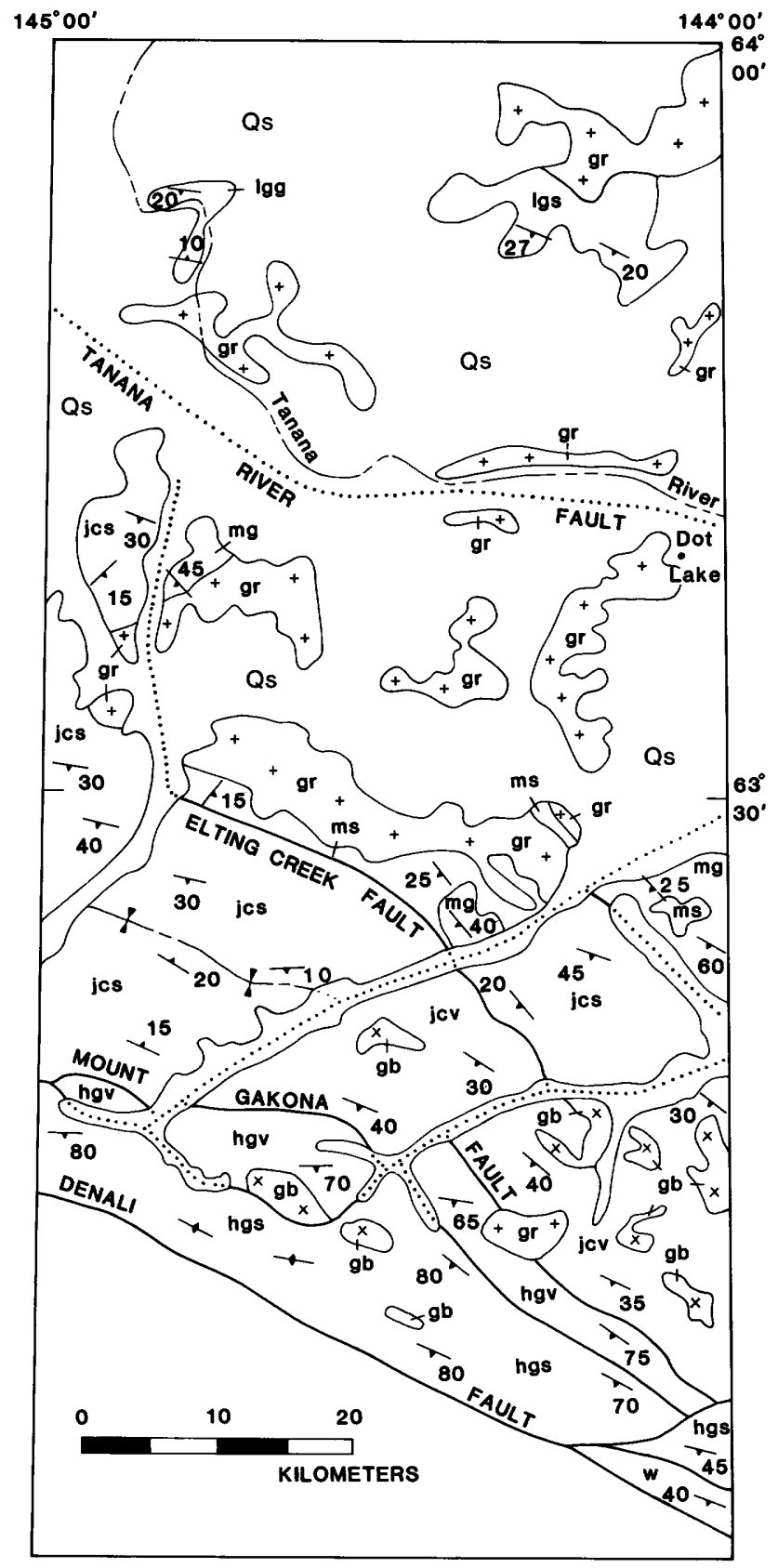

EXPLANATION

Qs

Surficial deposits

- QUATERNARY

${ }^{t}$ gr

Granitic rocks

$x^{g b^{x}}$

Gabbro

CRETACEOUS

LAKE GEORGE TERRANE

Igg

Metamorphosed

granitic rocks

Igs

Pelitic schist

MACOMB TERRANE

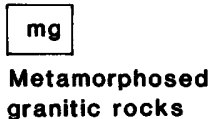

\begin{tabular}{l|l}
\hline ms & \\
$\begin{array}{l}\text { Metasedimentary } \\
\text { rocks }\end{array}$ & -DEVONIAN \\
OR OLDER
\end{tabular}

JARVIS CREEK

GLACIER TERRANE

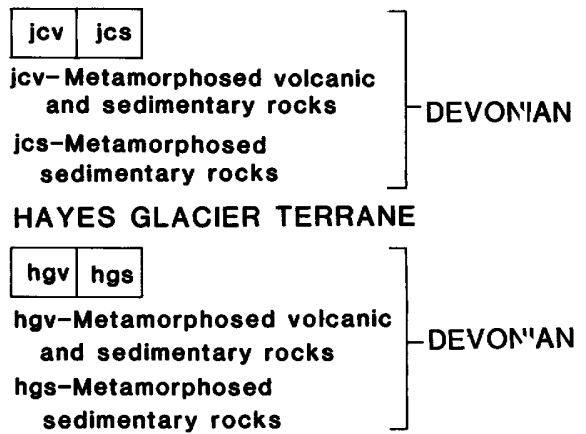

WINDY TERRANE

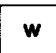

JDEVON'AN

SYMBOLS

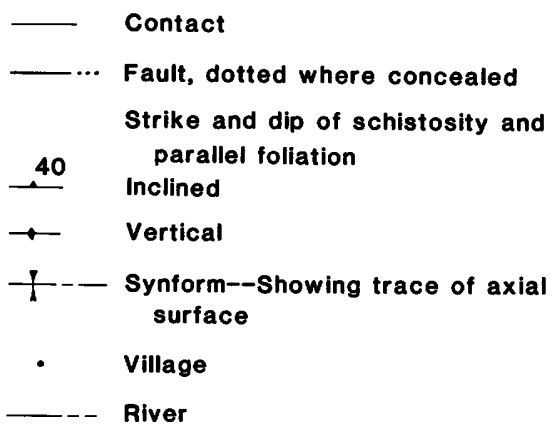
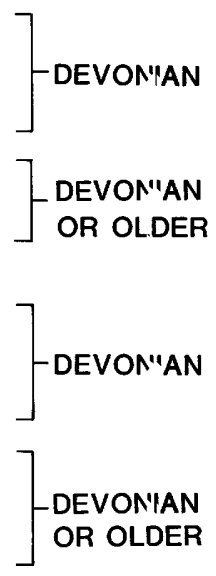

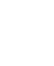

Figure 46.--Simplified bedrock geologic map of the northeastern Mount Hayes quadrangle, eastern Alaska Range. 
Table 16.--Stratigraphy and petrology of Devonian igneous-arc terranes, northeastern Mount Hayes quadrangle, eastern Alaska Range

UNIT NAME

AGE DATA

DESCRIPTION, ORIGIN

METAMORPHIC GRADE, STRUCTURE

\section{Lake George terrane}

Augen schist and gne iss, sch is tose

Pelitic schist tic schist

about $360 \mathrm{~m} . \mathrm{y}$. (Devoni an and Miss is sippian)

Devonian or older granodiorite

Coarse-grained, quartz-feldsparbiotite-hornblende schist and gneiss. Dikes and intrudes peli-

$\mathrm{U}-\mathrm{Pb}$ zircon ages of $370 \mathrm{~m} . \mathrm{y}$. (Devonian)

monzonite, granodiorite and quartz diori te

Pelitic-, calc-, and Devonian or older quartz-schist
Coarse-grained, white micaquartz-biot ite-garnet schist. Derived from quartz-rich to clay-rich shale
Macamb terrane

Fine - to medium-gra ined, schistose bi otite-hornblende granitic rocks. Form irregular, hypabyssal, small plutons and dikes intruding metasedimentary sch ist

Fine-to medium-grained schist with mica-, quartz-, and calcsilicate-rich layers. Derived from shale, marl, and quartz sands tone
Middle to upper amphibolite facies. Mylonitic schist with intense subhorizontal schistosity. Higher grade minerals of hornblende, biotite, plagioclase. Local retrogression to lower greenschist facies

Middle to upper amphibolite facies. Mylonitic schist with intense subhorizontal schistosity. Higher grade minerals of hornblende, biotite, garnet, staurolite, sillimanite. Refolded, subhorizontal schistosity and foliation

Lower amphibolite facies. Mylonitic schist with intense south-dipping schistosity. Local retrogressive metanorphism to lower greenschist facies

Lower amphibolite facies. Mylonitic schist with intense south-dipping schistosity. Higher grade minerals of bi ot ite, andalus ite, garnet, staurolite, sillimanite. Refolded schistosity anc foliation. Local retrogression to lower greenschist facies

\section{Jarvis Creek Glacier terrane}

Chlor ite-feldspar-quartz schist derived from meta-andesite, metaquartz keratophyre, and lesser metadac i te. Inter layered wi th metasedimentary schist

Metasedimentary schist Devonian (interlayered wi th metavolcanic schist, above)

Chlorite-, quartz-, and lesser calc schist, dark schist, and chlorite-feldspar-quartz sch ist. Derived from fine-grained sedimentary and volcanogenic rocks

\section{Hayes Glacier terrane}

Metavolcanic phyllite garnet, and biotite. Intense
$\mathrm{U}-\mathrm{Pb} \mathrm{zircon}$ ages of $370 \mathrm{~m} . \mathrm{y}$. (Devonian)

Chlorite-feldspar-quartz phyllite derived from meta-andesite, metaquartz keratophyre, and lesser metadacite. Inter layered with metasedimentary phyllite

Devonian (interlayered Chlorite-, quartz-phyllite. with metavolcanic phyllite, above) Lesser calc-phyllite, graphite phyllite, and marble. Derived from fine-grained sedimentary rocks
Middle to upper greensch ist facies. Mylonitic schist, intense south-dipping schistosity. Higher grade mirerals of white mica, chlorite, garnet, biotite. Intense retrogression to lower greenschist facies. Refclded schistosity and foliztion

Middle to upper greensct ist facies. Mylonitic schist, intense south-dipping schistosity. Higher grade mirerals of white mica, chlorite, retrogression to lower greenschist facies. Refolded schistosity and foliation

Lower greenschist facies. Mylonitic phyllonite with intense, steep-south-dipping schistosity. Highergrade minerals of white mica, chlorite, actinolite. Sparse relict biotite and garnet. Refolded schistosity and foliation

Lower greenschist facies. Mylonitic phyllonite with intense, steep-south-dipping schistosity. Highergrade minerals of white mica, chlorite. Refolded schistosity and foliation 
schistosity, both containing amphibolite-facies metamorphic minerals (table 16). Schistosity and foliation dip gently south (fig. 46). Sparse retrogressive greenschist-facies metamorphism occurs along major or minor cataclastic shear zones. Extensive granitic plutons of Late Cretaceous and early Tertiary age (Wilson, 1976; Dadisman, 1980; Wilson and others, 1985) intrude parts of the Lake George and Macomb terranes and, to a lesser extent, the Jarvis Creek Glacier and Hayes Glacier terranes. In all four terranes, these granitic rocks exhibit thin contact-metamorphic aureoles, which in a few areas are cataclastically deformed and metamorphosed under conditions of the lower greenschist facies.

The Macomb terrane consists of a sequence of fine- to medium-grained mylonitic schist derived from fine-grained clastic and calcareous sedimentary rocks intruded by schistose Devonian quartz monzonite to quartz diorite, which in a few areas is almost completely recrystallized to medium-grained mylonitic schist (Nokleberg and others, 1983; Aleinikoff, 1984; Aleinikoff and Nokleberg, this volume). Schistose granitic rock occurs as small, irregular hypabyssal plutons and dikes intruding metasedimentary schist. Both suites are multiply deformed and metamorphosed under conditions of the lower amphibolite facies, with local areas of retrograde greenschist-facies metamorphism (table 16); schistosity and foliation dip gently to moderately south (fig. 46). Greenschist-facies metamorphism occurs parallel to axial planes of younger structures.

The Jarvis Creek Glacier terrane consists of Devonian metavolcanic and metasedimentary mylonitic schist and minor phyllonite (Nokleberg and others, 1983). Part of this terrane was interpreted to be Early Proterozoic in age; however, new isotopic data indicate that Devonian zircons contain radiogenic lead derived from an Early Proterozoic source (Aleinikoff, 1984; Aleinikoff and Nokleberg, 1984a; Aleinikoff and Nokleberg, this volume). Metavolcanic schists are derived mainly from andesite and quartz keratophyre, and from lesser amounts of dacite and basalt. Metasedimentary schists are derived from fine-grained clastic, calcareous, and volcanogenic sediments. In some areas, volcanogenic massive sulfide deposits occur extensively in the terrane (Nauman and others, 1980; Lange and Nokleberg, 1984; Nokleberg and Lange, 1985). A submarine origin is indicated for these deposits by interlayering of metavolcanic rocks and sulfide lenses and pods with fine-grained, thinly layered metasedimentary rocks. Both suites of metavolcanic and metasedimentary rocks are multiply deformed and metamorphosed with pervasive, younger, middle to upper greenschist-facies minerals, and sparse areas of older, relict lower amphibolite-facies minerals (table 16). Schistosity and foliation dip gently to moderately south, but in a few areas they are warped into broad east-west-trending synforms and antiforms. Greenschist facies meta- morphism occurs parallel to axial planes of younger structures.

The Hayes Glacier terrane, consisting of Devonian metasedimentary and metavolcanic phyllonites (Aleinikoff, 1984; Aleinikoff and Nokleberg, $1984 \mathrm{~b}$; Aleinikoff and Nokleberg, this volume), is derived from many of the same protoliths as the Jarvis Creek Glacier terrane. The Hayes Glacier terrane differs from the Jarvis Creek Glacier terrane in having: (1) a greater abundance of black to dark-gray carbonaceous pelitic rocks; (2) snarsely occurring, small volcanogenic massive-sulfide deposits; (3) few metavolcanic and volcanically derived rocks; (4) more intense cataclasis; (5) abundant phyllonites; (6) no areas with relict amphibolite-facies metamorphism; and (7) overall a lower grade of metamorphism. The Hayes Glacier terrane is also multiply deformed and may be multiply metamorphosed at conditions of lower greenschist facies (table 16), but the later deformation and metamorphism was so intense as to obliterate all areas of relict higher grade metamorphism. Schistosity and foliation generally dip steeply south to vertically (fig. 46). Local intense cataclasis has formed extremely fine-grained blastomylonites, parallel to the axial planes of the younger generation of structures.

Structurally, the Lake George, Macomb, Jarvis Creek Glacier, and Hayes Glacier terranes occur on the south limb of a major east-west-striking antiform whose axial plane is north of the Tanana River and figure 46. The Lake George terrane, gently dipping to the south, occurs near the core of the antiform. The Macomb, Jarvis Creek Glacier, and Hayes Glacier terranes occur at successively higher structural levels on the south limb of the antiform; dips steepen progressively to the south, and are near-vertical along the Dencli fault (fig. 46). The structural stacking of these terranes is significant; stratigraphically higher level metaigneous rocks occur in structurally higher level terranes (fig. 46, table 16). For example, metamorphosed deep-levelplutonic rocks occur in the Lake George terrane, metamorphosed hypabyssal plutonic rocks occur in the Macomb terrane, and sul marine metavolcanic rocks occur in the Jarvis Cre?k Glacier and Hayes Glacier terranes (fig. 46, tablo 16).

Thus, the stratigraphy and structural rolations discussed herein indicate that these terrane: represent, from north to south, successively higher levels of a single, now highly metamorphosed and deformed Devonian submarine igneous-arc. Tre augen gneiss cropping out to the north and east, derived from Mississippian granitic plutonic rocks (DuselBacon and Aleinikoff, 1985; J. N. Aleinikoff, Cynthia Dusel-Bacon, and H. L. Foster, written commun., 1985), may be a deeper level part of the arc. An island-are origin may also be indicated by the occurrence of former submarine volcanic and sedimentary rock, and associated volcanogeric massive-sulfide deposits in the Jarvis Creek Glacier and Hayes Glacier terranes (Lange and Nokleber $r$, 1984; 
Nokleberg and Lange, 1985). However, a continental-margin are origin may be indicated by preliminary common lead isotopic studies on sulfide samples from these deposits (LeHuray and others, 1985), and similar studies on feldspars from the metaplutonic and metavolcanic rocks in these terranes (Aleinikoff, 1984), which indicate a continental component derived from an Early Proterozoic source. A continental margin setting is also indicated by the abundant quartz-rich schist in the Lake George, Jarvis Creek Glacier and Hayes Glacier terranes; many contain zircons with continental-derived Early Proterozoic lead (Aleinikoff and others, 1984; Dusel-Bacon and Aleinikoff, 1985). The data support two hypotheses for the origin of these terranes: (1) an island-arc origin, with the arc containing a slice of continental crust which contaminated later magmas; or (2) a submerged continental margin arc, with continental detritus being shed into a companion trench and subduction zone system. A modern-day analogue for the island arc origin is the New Zealand setting; the analogue for the submerged continental margin are setting is the Aleutian are (Kay and others, 1978).

\section{REFERENCES CITED}

Aleinikoff, J. N., 1984, Age and origin of metaigneous rocks from terranes north and south of the Denali fault, Mount Hayes quadrangle, east-central Alaska (abs.): Geological Society of America Abstracts with Programs, v. 16, p. 266.

Aleinikoff, J. N., Dusel-Bacon, Cynthia, Foster, H. L., and Futa, Kiyoto, 1981, Proterozoic zircon from augen gneiss, Yukon-Tanana Upland, east-central Alaska: Geology, v. 9, p. 469-473.

Aleinikoff, J. N., Foster, H. L., Nokleberg, W. J., and Dusel-Bacon, Cynthia, 1984, Isotopic evidence for detrital zircons from Early Proterozoic crustal material, east-central Alaska, in Coonrad, W. L., and Elliott, R. L., eds., The United States Geological Survey in AlaskaAccomplishments during 1981: U.S. Geological Survey 868, p. 43-45.

Aleinikoff, J. N., and Nokleberg, W. J., 1984a, Early Proterozoic metavolcanic rocks in the Jarvis Creek Glacier tectonostratigraphic terrane, Mount Hayes C-6 quadrangle, eastern Alaska Range, Alaska, in Reed, K. M., and BartschWinkler, Susan, eds., The United States Geological Survey in Alaska-Accomplishments during 1982: U.S. Geological Survey Circular 939 , p. 40-44.

Aleinikoff, J. N., and Nokleberg, W. J., 1984b, Uranium-lead geochronology of a metarhyolite from the Pingston terrane, Mount Hayes C-6 quadrangle, eastern Alaska Range, Alaska, in Coonrad, W. L., and Elliott, R. L., eds., The United States Geological Survey in AlaskaAccomplishments during 1981: U.S. Geological Survey Circular 868, p. 73-75.
Aleinikoff, J. N., and Nokleberg, W. J., 1985a, Age of intrusion and metamorphism of a granodiorite in the Lake George terrane, northeastern Mount Hayes quadrangle, Alaska, in BartschWinkler, Susan, and Reed, K. M., eds., The United States Geological Survey in AlaskaAccomplishments during 1983: U.S. Geological Survey Circular 945, p. 62-65.

Aleinikoff, J. N., and Nokleberg, W. J., 1985b, Age of Devonian igneous-arc terranes in the northern Mount Hayes quadrangle, eastern Alaska Range, Alaska, in Bartsch-Winkler, Susan, ed., The United States Geological Survey in Alaska-Accomplishments during 1984: U.S. Geological Survey Circular 967, th is volume.

Dadisman, S. V., 1980, Radiometric ages of rocks in the south-central Alaska and western Yukon Territory: U.S. Geological Surv?y Open-File Report $80-183,82$ p., 1 sheet, scale $1: 1,000,000$.

Dusel-Bacon, Cynthia, and Aleinikoff, J. N., 1985, Petrology and significance of augen gneiss from a belt of Mississippian granitoids in the Yukon-Tanana terrane: Geological Society of America Bulletin, v. 96, p. 411-4乞 5 .

Jones, D. L., Silberling, N. J., Berg, H. C., and Plafker, George, 1981, Map shoving tectonostratigraphic terranes of Alasl'a, columnar sections, and summary descriptions of terranes: U.S. Geological Survey Open-File Report 81-792, 20 p., 1 sheet, scale $1: 2,500,000$.

Kay, R. W., Sun, S. S., and Lee-Hu, C. N., 1978, Pb and $\mathrm{Sr}$ isotopes in volcanic rocks from the Aleutian Islands and Pribilof Islands, Alaska: Geochimica et Cosmochimica Acta, v. 42, p. 263-274.

Lange, I. M., and Nokleberg, W. J., 1984, Massive sulfide deposits of the Jarvis Creek Glacier terrane, Mount Hayes quadrangle, eastern Alaska Range, Alaska (abs.): Geological Society of America Abstracts w:th Programs, v. 16, p. 294.

LeHuray, A. P., Church, S. E., and Nokleberg, W. J., 1985, Lead isotopes in massive sulfide deposits from the Jarvis Creek Glacier and Wrangellia terranes, Mount Hayes quadrangle, eastern Alaska Range, Alaska, in Bartsch-Winkler, Susan, and Reed, K. M., eds.. The United States Geological Survey in Alaska-Accomplishments in 1983: U.S. Geological Survey Circular 945, p. 72-73.

Nauman, C. R., Blakestad, R. A., Chipp, E. R., and Hoffman, B. L., 1980, The nortl flank of the Alaska Range, a newly discovere t volcanogenic massive sulfide belt (abs.): Geological Association of Canada Program with Abstracts, p. 73.

Nokleberg, W. J., Aleinikoff, J. N., and Lange, I. M., 1983 , Origin and accretion of Anjean-type and island arc terranes of Paleozo:c age juxtaposed along the Hines Creek fault, Mount 
Hayes quadrangle, eastern Alaska Range, Alaska (abs.): Geological Society of America Abstracts with Programs, v. 15, p. 427.

Nokleberg, W. J., Schwab, C. E., Miyaoka, R. T., and Buhrmaster, C. L., 1984, Stratigraphy, petrology, and structure of the Pingston terrane, Mount Hayes C-5 and C-6 quadrangles, eastern Alaska Range, Alaska, in Coonrad, W. L., and Elliott, R. L., eds., The United States Geological Survey in AlaskaAccomplishments during 1981: U.S. Geological Survey Circular 868, p. 70-73.

Nokleberg, W. J., and Lange, I. M., 1985, Volcanogenic massive sulfide occurrences, Jarvis Creek Glacier terrane, western Mount Hayes quadrangle, eastern Alaska Range, Alaska, in Bartsch-Winkler, Susan, and Reed, K. M., eds., The United States Geological Survey in Alaska--Accomplishments during 1983: U.S. Geological Survey Circular 945, p. 77-80.

Wilson, F. H., 1976, Map showing potassium-argon ages from the Big Delta quadrangle, east-central Alaska Range: Alaska Division of Geological and Geophysical Surveys Geologic Report 46, 32 p.
Wilson, F. H., Smith, J. B., and Shew, Nora, 1985, Review of radiometric data from the Yukon Crystalline terrane, Alaska and Yukon Territory: The evidence for geochronology: Canadian Journal of Earth Sciences, v. 22, no. 4, p. 525-537

Reviewers: Cynthia Dusel-Bacon and M. A. Lanphere

\section{EARLY PENNSYLVANIAN CONODONTS FROM THE STRELNA FORMATION, CHITINA VALLEY}

\section{George Plafker, Anita G. Harris, and Katherine M. Reed}

The name Strelna Formation was originally applied to a complex of variably metamorphosed rocks in the Chitina Valley and Wrangell Mountains containing a megafaunal assemblage of supposed Mississippian age (Moffitt and Mertie, 1923; Moffitt, 1938, p. 22-29; pl. 1); from the descriptions, it is probable that younger nonmetamorphosed bedded rocks were locally included in the unit.

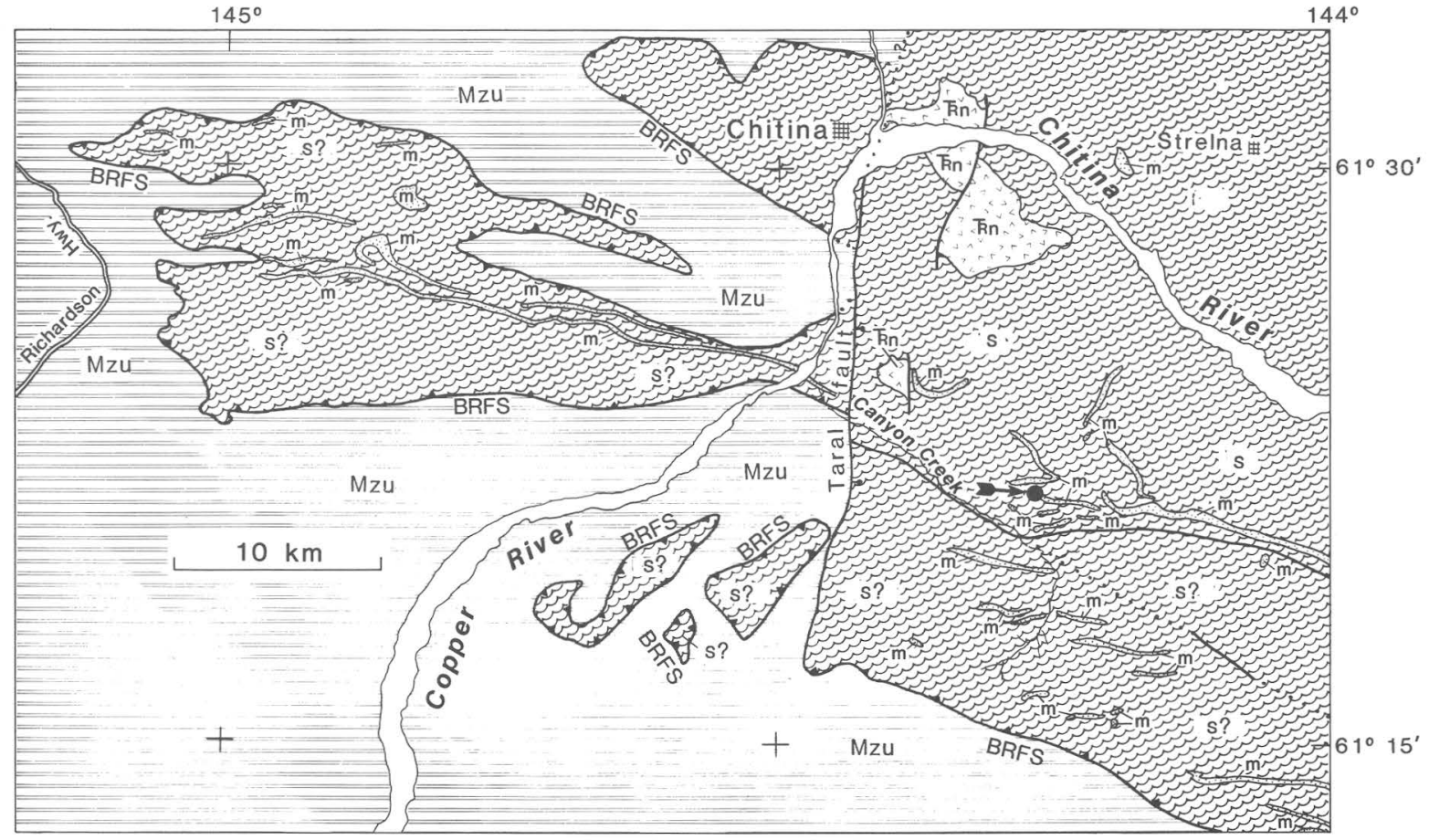

Figure 47.--Location of conodont sample 84APr67 (arrow, black dot) in the southeastern part of the Valdez quadrangle, distribution of the Strelna Formation (s) and possibly equivalent rocks of the Haley Creek terrane (s?), thicker marble beds in the $\mathrm{s}$ and $\mathrm{s}$ ? units (m), undifferentiated Triassic Nikolai Greenstone and Chitistone Limestone (Trn), undifferentiated Mesozoic flysch and melange of the Chugach terrane (Mzu), and the Border Ranges fault system (BRFS). Plutonic rocks and unconsolidated deposits not shown. Geology modified from Winkler and others (1981). 
In Chitina Valley (fig. 47), the formation consists of mafic to intermediate metavolcanic rock and minor pelitic schist, metachert, and marble. The country rock is intruded and metamorphosed by compositionally variable plutons of Late Pennsylvanian, Early Jurassic to Early Cretaceous, and late Cenozoic ages (MacKevett, 1978; MacKevett, 1978; Winkler and others, 1981). Also, a few, small, tectonically emplaced serpentinized ultramafic masses occur in the outcrop area, particularly along the Border Ranges fault system, which defines the southern boundary of the Strelna Formation (MacKevett and Plafker, 1974). Mineral assemblages are upper greenschist to lower amphibolite facies, commonly with rapid changes in metamorphic grade. The metamorphic sequence and Late Pennsylvanian plutonic rocks are strongly foliated, multiply deformed, and, in places, pervasively sheared and mylonitized.

The Strelna Formation was originally assigned a Carboniferous, probably Mississippian, age on the basis of poorly preserved brachiopods and other megafossils collected mainly from carbonate rocks (Moffitt and Mertie, 1923, p. 27-28, Moffitt, 1938, p. 26-29). Subsequent study of these and additional collections from marble in the metamorphosed Skolai Group suggested an Early Permian age for part of the Strelna Formation (MacKevett, 1978). On the basis of revised paleontologic data, MacKevett (1978) and Winkler and others (1981) considered the original Strelna Formation to be coeval with the lithologically similar, but less metamorphosed, Skolai Group, consisting of about $300 \mathrm{~m}$ of interbedded chert, shale, sandstone, and limestone with an abundant Early Permian megafauna (Smith and MacKevett, 1970). The Skolai Group is underlain by andesitic volcanic flows and volcaniclastic rocks; combined exposed thickness is about $2,000 \mathrm{~m}$. This sequence is considered to be Pennsylvanian in age (MacKevett, 1978) by correlation with the lower part of the fossiliferous Slana Spur Formation of the Mankomen Group, eastern Alaska Range (Richter and Dutro, 1975).

In the McCarthy quadrangle, the metamorphosed part of the sequence previously designated as Strelna Formation was mapped by MacKevett

Figure 48.--Scanning-electron photographs of biostratigraphically diagnostic Early Pennsylvanian (early Morrowan) conodonts from USGS collection 29342-PC, Strelna Formation (scale bar $=0.1 \mathrm{~mm}$ ). Most of the conodonts in the collection are juvenile elements. A, B; upper views of left and right $\mathrm{Pa}$ elements of Declinognathodus noduliferus (Ellison and Graves), 70x magnification. A, USNM 295835; B, USNM 295836, abraded. C, D; upper views of two juvenile left $\mathrm{Pa}$ elements of the Rhachistognathus muricatus Dunn)-R. primus (Dunn) plexus (D is broken anteriorly and posteriorly); C, USNM 295837, 90X magnification; D, USNM 295235, 135X magnification.
(1978) as "metamorphosed Skolai Group" (unit PPsm); in the adjacent Valdez quadrangle, it includes metamorphic rocks reassigned by Winkler and others (1981) to the undifferentiated Skolai Group (unit Ps), the unnamed "metamorphic complex" in the Dadina River area (unit Psm), and probably the country rock of the Haley Creek terrane (unit Khc).

During geologic mapping related to the TransAlaska Crustal Transect (TACT) project, 16 samples

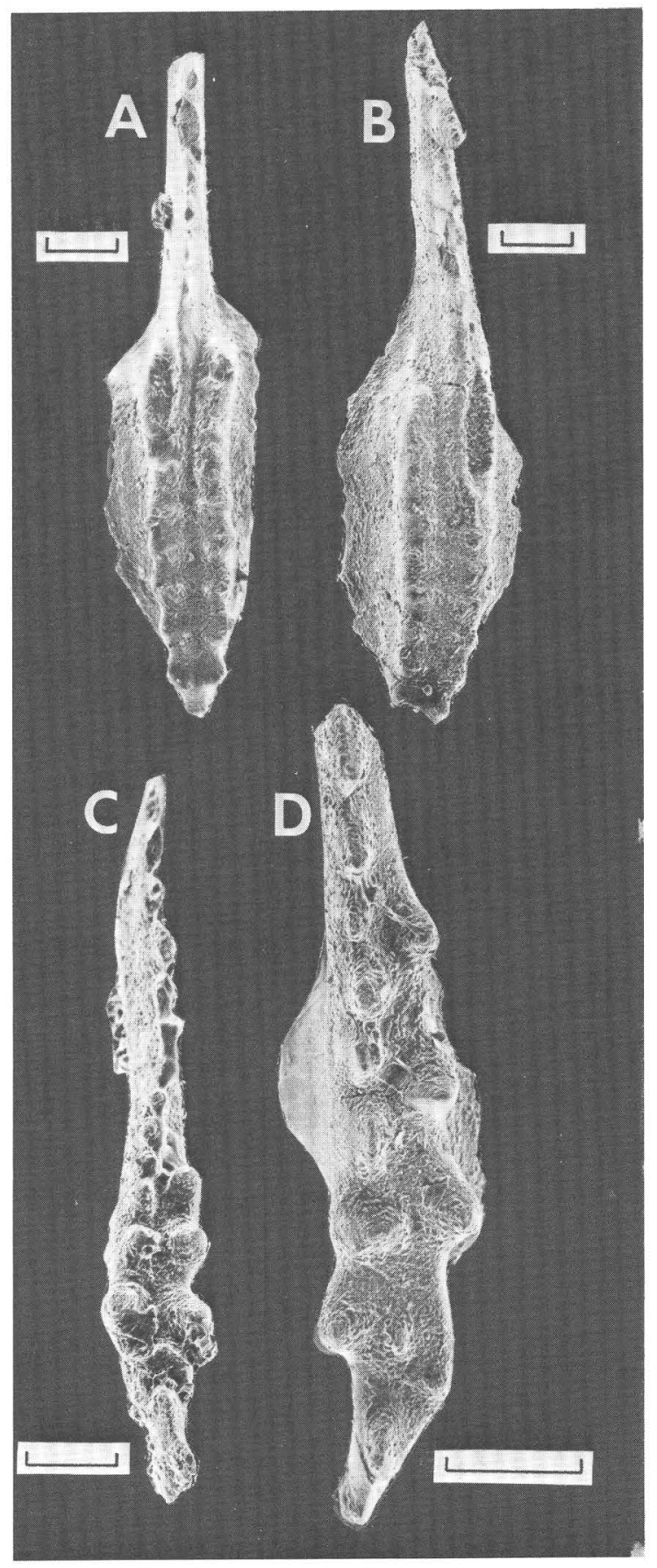


were collected from marble beds in the northern Chugach Mountains for conodont processing. Of these, one sample (84APr67) yielded a biostratigraphically diagnostic conodont assemblage (USGS collection 29342-PC). The locality is on a tributary of Canyon Creek at elevation $5,100 \mathrm{ft}$, SW1/4 sec. 12, T. 6 S., R. 6 E. (fig. 47), a locality cited by Moffitt (1914, p. 20; 1938, p. 27-28). However, megafossils collected were poorly preserved silicified crinoid columnals, brachiopods?, and corals, dated as "probable Carboniferous". Until now, this collection was the only age control in the extensive outcrop area of the pervasively metamorphosed Strelna Formation south of the Chitina River.

The conodont sample was collected close to the base of a bedded marble unit at least $100 \mathrm{~m}$ thick that is interbedded with schistose andesitic pyroclastic and flow rocks and minor metachert. Processing of $5.7 \mathrm{~kg}$ of marble yielded the following microfossils:

$17 \mathrm{~Pa}$ elements of the Rhachistognathus muricatus (Dunn)-R. primus (Dunn) plexus (figs. 48C, 2D)

Declinognathodus noduliferous (Ellison and Graves) (figs. $48 \mathrm{~A}, \overline{2 \mathrm{~B})}$

$77 \mathrm{~Pa}, 6 \mathrm{~Pb}, 1 \mathrm{Sb}$, and 2 Sc elements

150 indet. bar, blade, and platform fragments 40 ichthyoliths

1 phosphatized ostracode steinkern

The conodonts are a cosmopolitan, shallowand warm-water (in North America) species assemblage characteristic of the Declinognathodus noduliferous-Neognathodus bassleri symmetricus conodont zones of early Early Pennsylvanian age (early Morrowan). The color alteration index (CAI) of 5.5 indicates the host rock reached at least $350^{\circ} \mathrm{C}$, possibly during emplacement of the nearby Jurassic plutons.

These biostratigraphically diagnostic Early Pennsylvanian conodonts in the Strelna Formation suggest the following revisions of present geologic interpretations in this part of southern Alaska:

(1) The new fossil data show that the Strelna Formation includes strata of Early Pennsylvanian age that is older than the Permian, carbonate-bearing upper part of the Skolai Group. Although there may be temporal overlap with the undated lower part of the Skolai Group, correlation with it cannot be assumed. The higher grade of metamorphism and more extreme deformation of the Strelna Formation, and the occurrence of metaplutonic rock yielding $\mathrm{K}$-Ar apparent ages as old as Middle Pennsylvanian (MacKevett, 1978), contrast with the typical Skolai Group of the eastern Wrangell Mountains.

(2) The outcrop area of the Strelna Formation is in fault contact to the south and west with an undated metamorphic sequence delineated by Winkler and others (1981) and Wallace (1981) as the Haley Creek terrane (s?, fig. 47). Gross similarities in lithology, structural style, and plutonism suggest that the Haley Creek terrane may represent a deeper structural level of the Strelna Formation. In both units, metachert lenses and distinctive thin marble beds, many of which are continuous along strike for many kilometers, are particularly suggestive of correlation. In the absence of age-diagnostic fossils from the Haley Creek terrane, however, this correlation remains speculative.

(3) The Strelna Formation is tentatively considered part of the allochthonous Wrangellia terrane of Jones and others (1977). It is similar in lithology and age to upper Paleozoic andesitic units that comprise the basement to the Wrangellia terrane except that the Strelna Formation contains $\varepsilon$. higher percentage of marine metasedimentary rocks. Map relationships in the southeastern part of the Valdez quadrangle (Winkler and others, 1981) also surgest it is depositionally overlain by the characteristic Wrangellian Triassic sequence.

(4) G.H. Girty (in Moffitt, 1938, p. 28-29) noted that the megafauna from the Strelna Formation is the same as faunas from the Lisburne Group which crops out in northern Alaska in the Brooks Range. Conodont faunas reported herein confirm this correlation. Representatives $\mathrm{cf}$ the Rhachistognathus muricatus-R. primus plexus are common in the latest Mississippian and earliest Pennsylvanian part of the Lisburne Group across the Brooks Range and in collections from the Nuka Formation in the western Brooks Range. Declinognathodus noduliferus is present in the earliest Pennsylvanian part of this interval, but is less common. Specimens of $R$. muricatus heve also been recovered from thin carbonate beds and lenses in the Helpmejack Hills, south-central Brooks Range. Since these faunas are cosmopoliten, they cannot be used to deduce the Pennsylvanian paleolatitude for the terrane in which they o?cur.

(5) Systematic collection and processing of carbonate samples for conodonts from the Strelna Formation and possibly correlative units is required to better define the stratigraphic age range and geographic distribution of this unit.

\section{REFERENCES CITED}

Jones, D. L., Silberling, N. J., and Hillhouse, John, 1977, Wrangellia-a displaced terrone in northwestern North America: Canadian Journal of Earth Sciences, v. 14, p. 2565-2577.

MacKevett, E. M., Jr., 1978, Geologic map of the McCarthy quadrangle, Alaska: U.S. Geslogical Survey Miscellaneous Investigations Series Map I-1032, scale 1:250,000.

Mackevett, E. M., Jr., and Plafker, George, 1974, The Border Ranges fault in south-central Alaska: U.S. Geological Survey Journal of Research, v. 2, no. 3, p. 323-329.

Moffitt, F. H., 1914, Geology of the HanagitaBremner region, Alaska: U.S. Geslogical Survey Bulletin 576, 56 p. 
-Moffitt, F. H., 1938, Geology of the Chitina Valley and adjacent area, Alaska: U.S. Geological Survey Bulletin 894, 137 p.

Moffitt, F. H., and Mertie, J. B., Jr., 1923, The Kotsina-Kuskulana district, Alaska: U.S. Geological Survey Bulletin 745, 149 p.

Richter, D. H., 1976, Geologic map of the Nabesna quadrangle, Alaska: U.S. Geological Survey Miscellaneous Investigations Series Map I-932, scale $1: 250,000$.

Smith, J. G., and MacKevett, E. M., Jr., 1970, The Skolai Group in the McCarthy B-4, C-4, and C-5 quadrangles, Wrangell Mountains, Alaska: U.S. Geological Survey Bulletin 1274, p. Q1Q26.

Wallace, W. K., 1981, Structure and petrology of a portion of a regional thrust zone in the central Chugach Mountains, Alaska: Seattle, University of Washington, Ph.D. dissertation, 253 p.

Winkler, G. R., Silberman, M. L., Grantz, Arthur, Miller, R. J., and MacKevett, E. M., Jr., 1981, Geologic map and summary geochronology of the Valdez quadrangle, southern Alaska: U.S. Geological Survev Open-File Report 80-892-A, scale $1: 250,000$.

Reviewers: E. M. MacKevett, Jr., W. J. Nokleberg, and G. R. Winkler.

\section{SUMMARY OF DATA ON THE AGE OF THE ORCA GROUP, ALASKA}

\section{George Plafker, Gerta Keller, Steven W. Nelson, Julie A. Dumoulin, and Marti L. Miller}

The Orca Group is a widespread, thick, complexly deformed accretionary sequence of flysch and tholeiitic basalt in the Prince William Sound area (Winkler, 1976; Winkler and Plafker, 1981) (fig. 49). Despite a number of extensive field studies of the Orca Group, reliable data on the age of the unit have been elusive. On the basis of sparse paleontologic and radiometric data, the sequence was regarded as Paleocene and early Eocene(?) age (Winkler and Plafker, 1981). New paleontologic data from fossil localities shown in figure 49 suggest that some strata assigned to the Orca Group are of middle Eocene age and possibly as young as late Eocene or Oligocene. However, data suggesting an age younger than about $50 \mathrm{Ma}$ appear to be incompatible with radiometrically determined ages for plutons that intrude the Orca Group.

Age-diagnostic fossils in the Orca Group and the paleontologists who reported on them are: 24 foraminiferal assemblages examined in thin section (Gerta Keller), nine assemblages of radiolarians (Joyce R. Blueford and Charles D. Blome), one assemblage of diatoms and silicoflagellates (John A. Barron), one meager assemblage each of coccoliths (David J. Bukry), dinoflagellates (Lucy E. Edwards), palynomorphs (William R. Evitt), and megafossils (Stearns F. MacNeil, Warren O. Addicott, Ellen J. Moore). Checklists of all the paleontologic data with discussions of their age implications are presented elsewhere (Plafker and others, 1985). Age ranges for these fossils are indicated on figure 50. They are predominantly Paleocene through middle Eocene, but include some assemblages that range into the late Eocene or Oligocene.

'The bedded rocks of the Urca Group are tightly folded and extensively faulted. Th? deformed strata are intruded and variably metamorphosed by granodiorite, granite, and tonalite plutcns, with $\mathrm{K}-$ Ar ages from 50.5 to $53.5 \mathrm{Ma}( \pm 1.6 \mathrm{Ma})$ in eastern Prince William Sound and the area to the east (Winkler and Plafker, 1981, and unpublished data; fig. 49). Field relations suggest to us that all of the Orca Group from which fossils have been collected predates emplacement of the structurally discordant plutons.

Thus the combined paleontologic and radiometric data constrain the age of the Or a Group to late Paleocene through early middle Excene. The upper age limit is taken as the emplacement age of the late early to earliest middle Eocene plutons that intrude and metamorphose the sequence (fig. 50). The lower age range of the unit is not known but is probably Paleocene as it postdates the Maestrichtian Valdez Group. The age relationship of the strata at Jeanie Point and Neck Point cn Montague Island to the remainder of the Orca Gro'to is uncertain, but these strata most probably have shared the same deformational and metamorphic history as the remainder of the Orca Group (Dumoulin and Miller, 1984).

As shown by figure 50, all but ore fossil assemblage are older or within the age range of the Eocene plutons that intrude the $\mathrm{O}$ ca Group, although there is very little overlap with some of the middle Eocene fossils ranges. The only fossil assemblage definitely incompatible with a pre-early middle Eocene age for the Orca is the questionably assigned late Eocene or younger coccoliths from Neck Point.

Because the coccoliths at Neck Pcint occur in a section that also yields probable early Eocene radiolarians, a problem is indicited with identification and (or) the age range of the poorly preserved coccoliths. Detailed biostratigraphic studies of key sections are planned for the 1985 field season with the objective of better defining the age of the Orca Group.

\section{REFERENCES CITED}

Berggren, W. A., Kent, D. V., and Flynn, J. J., 1984, Paleogene geochronology and ehronostratigraphy, in Snelling, w. J., ed., Geochronology of the geologic time scale: Geologic 1 Society of London Special Paper, 137 p. 


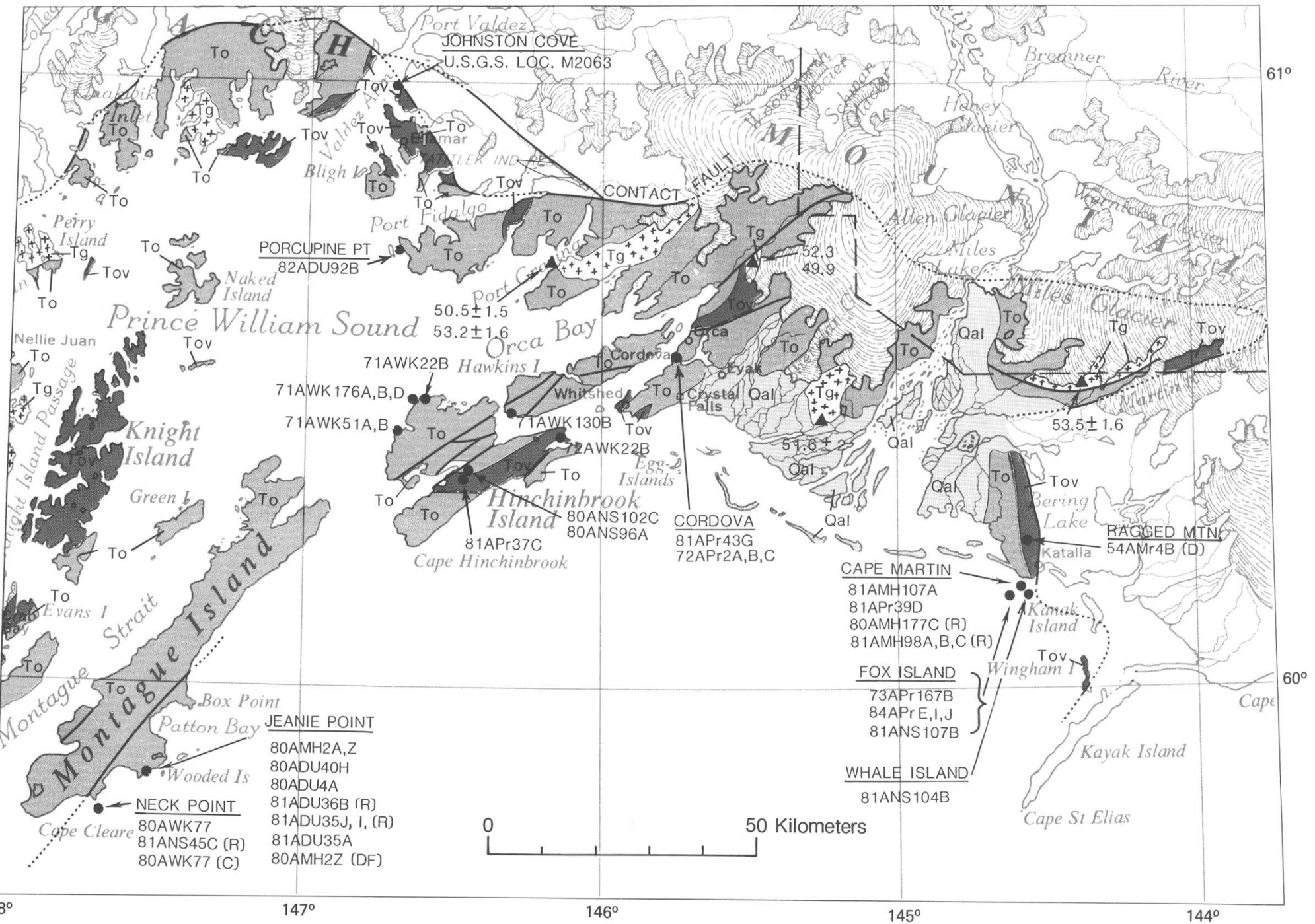

Figure 49.--Distribution of the Tertiary Orca Group (To, Tov) and Tertiary intrusive granitic rocks $(\mathrm{Tg})$ in the Prince William Sound and Katalla areas. Solid dots and numerals indicate fossil localities and sample numbers. $(\mathrm{M})=$ megafossils, $(\mathrm{C})=$ coccoliths, $(\mathrm{D})=$ diatoms and silicoflagellates, $(\mathrm{DF})=$ dinoflagellates, $(\mathrm{P})=$ pollen, $(\mathrm{R})=$ radiolarians; all other are foraminifers. Solid triangles are $\mathrm{K} / \mathrm{Ar}$-dated samples from plutons and the numerals are apparent ages in $\mathrm{Ma}$ (From Winkler and Plafker, 1981; and, unpub. data). 


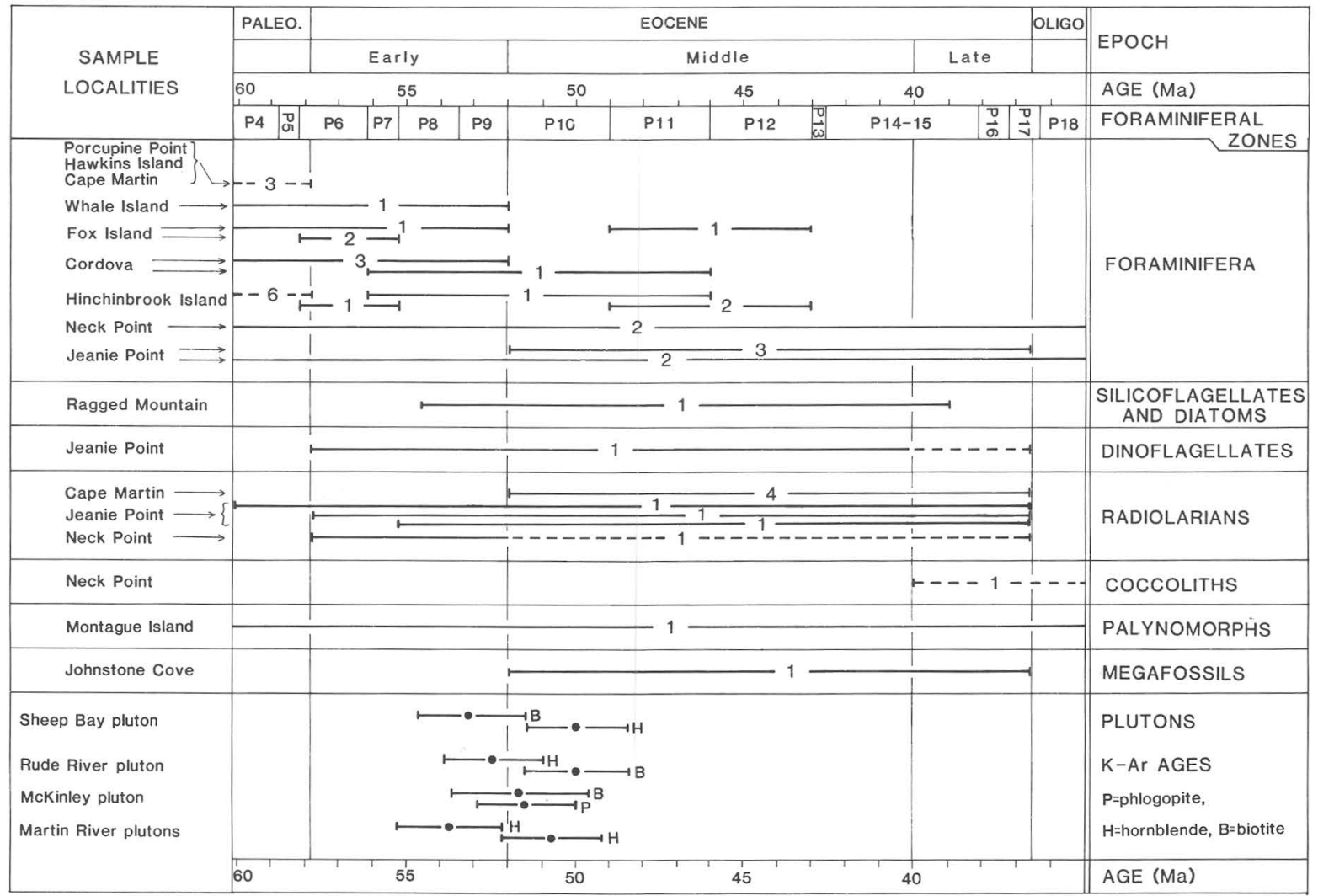

Figure 50.--Age ranges of fossil collections from the Tertiary Orca Group (numerals in parentheses indicate number of assemblages) and $\mathrm{K}$-Ar ages of mineral separates from plutons intrusive into the Orca Group. Dashed bars indicate questionable age assignments. Locations of samples and plutons shown on figure 49. Time scale after Berggren and others (1984).

Dumoulin, J. A., and Miller, M. L., 1984, The Julie Point complex revisited, in Coonrad, W. L. and Elliot, R. L., eds., The U.S. Geological Survey in Alaska-Accomplishments during 1981: U.S. Geological Survey Circular 868, p. 75-77.

Plafker, George, Keller, Gerta, Barron, J. A., Blueford, J. R., Nelson, S. W., Dumoulin, J. A., and Miller, M. L., 1985, Paleontologic data on the age of the Orca Group, Alaska: U.S. Geological Survey Open-File Report $85-429,22$ p.

Winkler, G. R., and Plafker, George, 1981, Preliminary geologic map of the Cordova and Middleton Island quadrangles, Alaska: U.S. Geological Survey Open-File Report 81-1164.

Reviewers: J. A. Barron and E. J. Moore

\section{SUMMARY OF \\ 1984 TACT GEOLOGIC STUDIES IN THE NORTHERN CHUGACH MOUNTAINS AND SOUTHERN COPPER RIVER BASIN}

\section{George Plafker, Warren J. Nokleberg, and John S. Lull}

(with contributions from

R. B. Coleman, T. L. Pavlis, G. H. Pessel,

R. C. Roback, V. B. Sisson, W. K. Wallace, and G. R. Winkler)

During the 1984 field season of the TransAlaska Crustal Transect (TACT) program, geologic mapping at a scale of 1:63,360 or larger and specialized studies were completed for a strip about $20 \mathrm{~km}$ wide and $100 \mathrm{~km}$ long. The study centered on the TACT route along the Richardson Highway, from east of Valdez in the northern Chugach Mountains to the southern Copper River basin and west margin of the Wrangell Mountains. Also, detailed petrologic studies were undertaken in the eastern Chugach Mountains near the east end of the Chugach seismic-refraction strike line (Fuis and others, 1985). 
Bedrock geologic mapping was completed in the Valdez B-3, B-4, C-3, and C-4 15-minute quadrangles, which span the complex suture of the Border Ranges fault system separating the Chugach terrane to the south and Wrangellia-Peninsular (composite) terrane to the north. This study presents a brief summary of the Chugach terrane and the Wrangellia-Peninsular (composite) terrane, a revised geologic map along the Border Ranges fault system, an interpretive section showing major features across the suture (fig. 52), and preliminary interpretations. Much of our work is based on previous studies by Metz (1975), Wallace (1981), Winkler and others (1981), and Burns (1984).

The Chugach terrane (fig. 51) is composed of three, fault-bounded, highly deformed accretionary sequences consisting of (south to north): (1) Late Cretaceous Valdez Group (Kv) greenschist facies flysch sequence; (2) Jurassic and Cretaceous McHugh Complex (KJm) sheared and weakly metamorphosed oceanic basaltic rocks, argillite, and chert (Winkler and others, 1981); and (3) the Early Jurassic or older greenschist and blueschist of Liberty Creek (Jlc). The Border Ranges fault system is herein defined as the system of faults that juxtapose the accreted and locally subducted deepsea sequences of the Chugach terrane against the Wrangellia-Peninsular (composite) terrane to the north; at the north margin, the Chugach terrane is underthrust northward beneath the Wrangellia-Peninsular (composite) terrane along the Border Ranges fault system. West of the Copper River, the Border Ranges fault system includes faults previously mapped as the Border Ranges fault and the Spirit Mountain thrust by MacKevett and Plafker (1974). The Border Ranges fault system is characterized by broad shear zones that locally contain serpentinite or serpentinized ultramafic rocks. Geologic, gravity, and magnetic data suggest that rocks in the upper plate have been thrust at least $40 \mathrm{~km}$ over the Chugach terrane along the Border Ranges fault system, and that the thrust plates are thin sheets generally less than $1 \mathrm{~km}$ thick (fig. 51).

Two major crystalline rock sequences comprising the Wrangellia-Peninsular (composite) terrane (fig. 51) are mafic and ultramafic rocks herein informally referred to as the Tonsina complex (tcu, tcm) and metamorphosed sedimentary, volcanic, and plutonic rocks that are herein informally referred to as the Haley Creek metamorphic complex (hc). Volcaniclastic rocks of the Early Jurassic Talkeetna Formation ( $\mathrm{Jt}$ ) are believed to be in normal fault contact with the Tonsina complex beneath Quaternary cover in the northern part of the map area (fig. 51); this normal fault may occur along a major unconformity.

The Haley Creek metamorphic complex consists of multiply deformed and metamorphosed, interlayered, mafic to intermediate volcanic rocks, pelite, sandstone, and marble. The layered rocks are extensively intruded by compositionally diverse metaplutonic rocks ranging in composition from gabbro to trondhjemite, but dominantly diorite and quartz diorite. Layered rocks included in the Haley Creek unit predate emplacement of the oldest metaplutonic rocks, which are dated as Late Jurassic $(153+4 \mathrm{Ma})$ by $\mathrm{U}-\mathrm{Pb}$ zircon methods (J. N. Aleiniko $\overline{f f}$, USGS, written commun., 1984). These layered rocks are tentatively correlated with less metamorphosed rocks of the Strelna Formation east of the Copper River containing fossils of Early Pennsylvanian age (Plafker and others, 1985).

The Tonsina (mafic-ultramafic) comp? ex is a distinctive, high-pressure assemblage of northwarddipping layered dunite, harzburgite, websterite, and garnet amphibolite, and hornblende-bearirg twopyroxene gabbros (Coleman and Burns, 1985). The complex consists of a lower ultramafic sequence less than $1 \mathrm{~km}$ thick and an upper mafic sequence that may be as much as $6 \mathrm{~km}$ thick, if it is not structurally imbricated. The age of the Tonsina complex is uncertain. $\mathrm{K}$-Ar analyses of hornblende from four mafic samples near Tonsina have yielded apparent ages ranging from Silurian to Jurassic $(419,369,188$, and $171 \mathrm{Ma})$; west of the highway seven gabbro samples have yielded Middle and Late Jurassic (180-154 Ma) hornblende $\mathrm{K}-\mathrm{Ar}$ apparent ages (Winkler and others, 1981; and unpub. data). Some of these ages may have been reset during intrusion of voluminous, more silicic Jurassic plutons. The Tonsina (mafic-ultramafic) complex is part of a belt extending westward along the south margin of the Peninsular terrane and interpreted as the root of the Jurassic Talkeetna magmetic arc (Burns, 1985). However, the structural relationship of the Tonsina (mafic-ultramafic) complex to the adjacent schist of the Liberty Creek unit and Talkeetna Formation, the occurrence of at least two pre-Jurassic K-Ar ages, and the likelihood of resetting of mineral ages by widespread Jurassic plutonism suggest that at least the ultramafic part of the Tonsina complex may be part of an older, late Paleozoic arc upon which the Talkeetna arc was superimposed.

The above data suggest the following tentative sequence of events that juxtaposed terranes along the Border Ranges fault system: (1) Evolution of a Pennsylvanian and older(?) andesitic arc, now represented by the Haley Creek metamorphic complex; the Tonsina (mafic-ultramafic) complex may be part of a deep-level root to this arc. (2) PreMiddle Jurassic subduction of the schist of the Liberty Creek unit along the Border Rangiss fault system, forming south-verging structures ant metamorphosing the rocks to transitional blueschistgreenschist facies. (3) Widespread Middle and Late Jurassic plutonism associated with the Telkeetna magmatic arc forms the intermediate calc-alkaline suite of plutons which intrudes the mafic complex and the stratified rocks of the Haley Creek unit. (4) Late Jurassic and Early Cretaceous pl'itonism occurs in approximate synchroneity with formation of south-verging structures, upper greenschist- to amphibolite-facies metamorphism, and ductile def- 


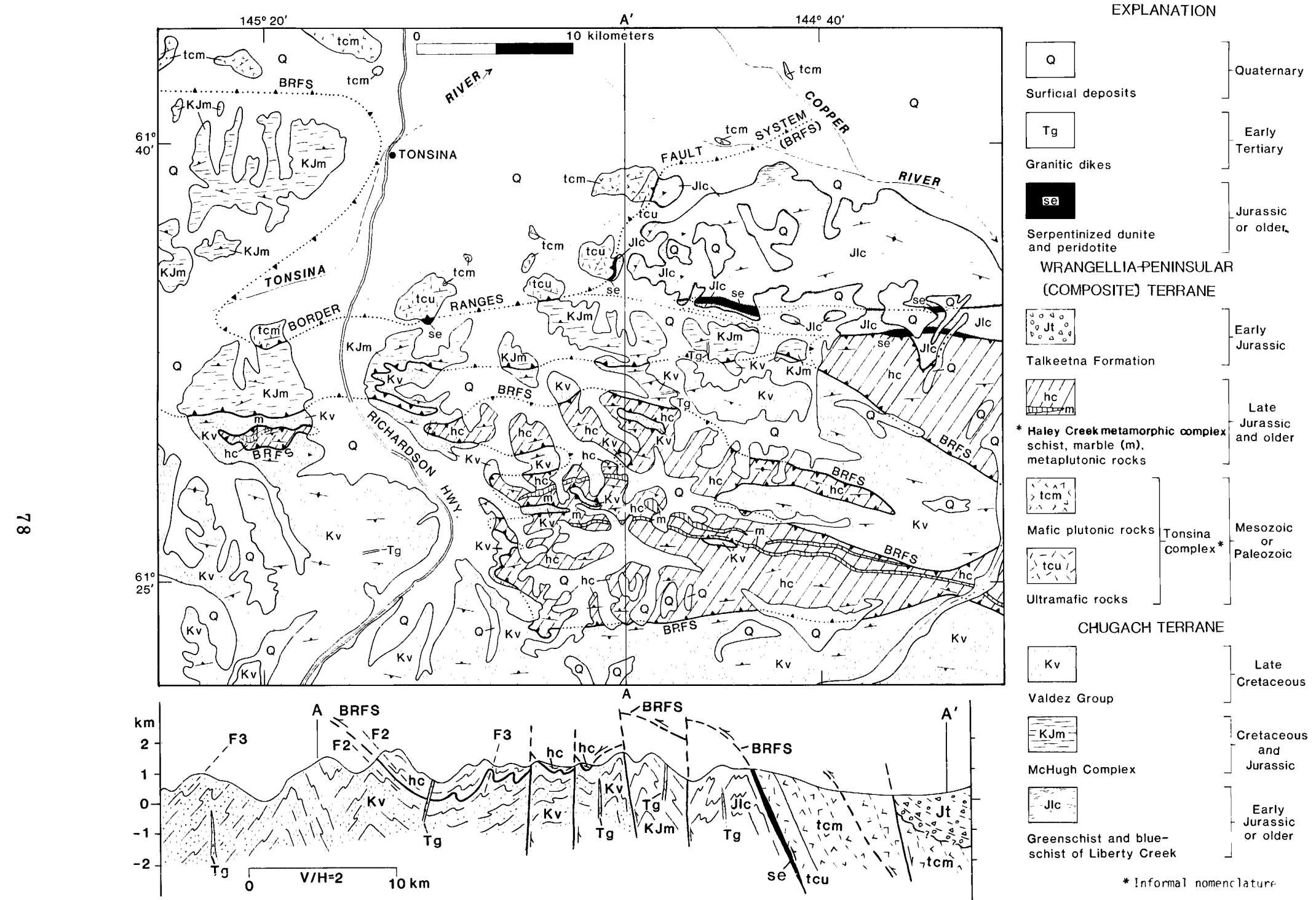

Figure 51.--Location and geologic setting of the Border Ranges fault system, the suture zone between the Chugach terrane and the Wrangellia-Peninsular (composite) terrane along the TACT route. Revised after Metz (1975), Winkler and others (1981), and Wallace (1981). Generalized section ( $\mathrm{AA}^{\prime}$ ) showing structural style and relationship between major geologic units in the Border Ranges fault system. 
ormation of the Haley Creek unit. Widespread, intense, locally mylonitic cataclasis postdates Jurassic plutonism and probably continues through much or all of the Cretaceous. (5) Deformation and accretion of the McHugh Complex occurs during subduction in middle(?) Cretaceous time, with formation of poorly developed, south-verging structures, pervasive shear zones, and local melange. (6) Accretion of the Valdez Group occurs in Late Cretaceous time, forming south-verging structures and resulting in at least $40 \mathrm{~km}$ of relative underthrusting beneath the Haley Creek unit. (7) Overprinting takes place during Late Cretaceous and (or) early Tertiary time due to pervasive northward-verging major and minor folding in the accretionary sequences of the northern Chugach terrane and in the overlying Haley Creek unit. (8) Early Tertiary regional greenschist- to zeolitefacies metamorphism takes place in the Valdez Group and McHugh Complex and retrograde metamorphism occurs in the Haley Creek unit. (9) Crosscutting early middle Eocene felsic dikes and stocks are emplaced in the Chugach terrane and Haley Creek unit. Events 7-9 were probably essentially synchronous. Uplift and erosion of $30-40 \mathrm{~km}$ along the Border Ranges fault system since Jurassic time has exposed the blueschist-facies rocks and the Tonsina (mafic-ultramafic) complex. If the Tonsina complex is unconformably overlain by the unmetamorphosed Talkeetna Formation, then the Tonsina complex was uplifted and eroded $15-30 \mathrm{~km}$ before deposition of the Early Jurassic Talkeetna Formation took place.

\section{REFERENCES CITED}

Burns, L. E., 1985, The Border Ranges ultramafic and mafic complex, south-central Alaska: cumulate fractionates of island arc volcanics: Canadian Journal of Earth Sciences, v. 22 , no. 7 , p. 1020-1038.

Coleman, R. G. and Burns, L. E., 1985, The Tonsina complex, Chugach Mountains, a high-pressure mafic-ultramafic cumulate sequence (abs.): Bulletin of the Geological Society of America, v. 17 , no. 6 , p. 248 .

Fuis, G. S., Ambos, E. L., Mooney, W.D., Page, R.A., and Campbell, D. L., 1985, Preliminary results of TACT 1984 seismic-refraction survey of southern Alaska, in Bartsch-Winkler, Susan, ed., The United States Geological Survey in Alaska-Accomplishments during 1984: U.S. Geological Survey Circular 967, this volume.

Metz, P. A., 1975, Occurrences of sodic amphibolebearing rocks in the Valdez $\mathrm{C}-2$ quadrangle, in Short notes on Alaskan geology 1976: Alaska Division of Geological and Geophysical Surveys Geologic Report 51, p. 27-28.

MacKevett, E. M., Jr., and Plafker, George, 1974, The Border Ranges fault in south-central Alaska: U.S. Geological Survey Journal of Research, v. 2, no. 3, p. 323-329.
Plafker, George, Harris, A. G., and Reed, K. M., 1985, Early Pennsylvanian conodonts from the Strelna Formation, Chitina Valley area, Alaska, in Bartsch-Winkler, Susan, ed., The United States Geological Survey in AlaskaAccomplishments during 1984: U.S. Geological Survey Circular 967, this volume.

Wallace, W. K., 1981, Structure and petrology of a portion of a regional thrust zone in the central Chugach Mountains, Alaska: Seattle, University of Washington, Ph.D. dissertation, 253 p.

Winkler, G. R., Silberman, M. L., Grantz, Arthur, Miller, R. J., and MacKevett, E. M., Jr., 1981, Geologic map and summary geochronology of the Valdez quadrangle, southern Alaska: U.S. Geological Survey Open-File Report 80-892-A, scalè 1:250,000.

Reviewers: Cynthia Dusel-Bacon and G. S. Fuis

\section{SEISMICITY IN SOUTHERN ALASKA, OCTOBER 1983 - SEPTEMBER 1984}

\section{Christopher D. Stephens, Kent A. Fogleman, John C. Lahr, and Robert A. Page}

Hypocenters have been determined for 3,728 earthquakes recorded by the USGS seismograph network in southern Alaska between October 1983 and September 1984. The distribution of events larger than magnitude 3 is shown in figure 52 . During this period, the largest event was a magnitude $5.7 \mathrm{~m}_{\mathrm{b}}$ (5.2 $\mathrm{M}_{\mathrm{s}}$; body-wave, $\mathrm{m}_{\mathrm{b}}$, and surface-wave, $\mathrm{M}_{\mathrm{s}}$, magnitudes and Modified Mercalli intensity reports are taken from the Preliminary Determination of Epicenters of the USGS National Earthquake Information Service, NEIS) shock on August 14, 1984, located $24 \mathrm{~km}$ deep near Sutton, about $80 \mathrm{~km}$ northeast of Anchorage. This event was felt throughout much of southern Alaska from Fairbanks to Homer and had a maximum intensity of VI at Palmer and Willow where slight damage was reported (NEIS). The distribution of aftershocks and the focal mechanism for this event indicate that it occurred on the ENE-WSW-trending Talkeetna segment of the Castle Mountain fault, thus demonstrating that this segment of the fault is active (see Lahr and others, 1985). Two shocks of magnitude $5.4 \mathrm{~m}_{\mathrm{b}}\left(5.0 \mathrm{M}_{\mathrm{s}}\right)$ and $5.1 \mathrm{~m}_{\mathrm{b}}\left(4.6 \mathrm{M}_{\mathrm{S}}\right)$ with nearly identical epicenters occurred about 11 min apart on September 20 at shallow depth southeast of Hinchinbrook Island. These events were felt as far as Palmer and Chitina, and for the larger shock, a maximum intensity of IV was reported at Cordova, Anchorage, and Sutton (NEIS). The pair of events did not have a detectable aftershock sequence, but in the surrounding offshore region it is not unusual for double or single event shocks of comparable magnitude to occur without significant aftershock activity. Three other events of magnitude $5 \mathrm{~m}_{\mathrm{b}}$ and larger occurred dur- 


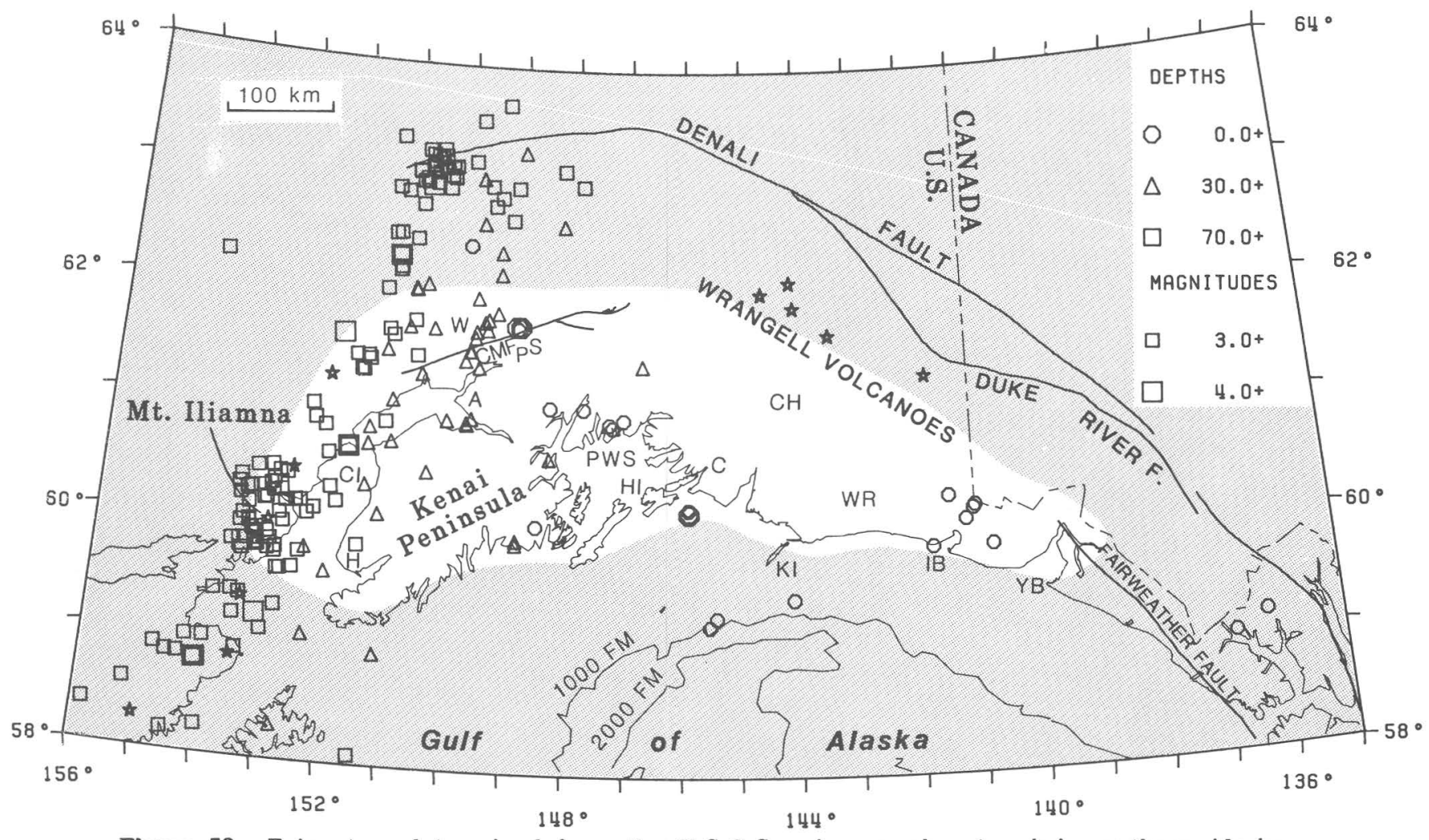

Figure 52.--Epicenters determined from the U S G S seismograph network in southern Alaska for 201 earthquakes with coda-duration magnitude 3 and larger that occurred in the period October 1983-September 1984. Symbol type and size correspond to depth and magnitude as indicated; six heavy symbols indicate events of magnitude $5 \mathrm{~m}_{\mathrm{b}}$ and larger as determined by NEIS. Non-shaded area indicates approximate extent of network of seismograph stations most frequently used to locate earthquakes; hypocenters located outside of the network tend to be less reliable. A, Anchorage; C, Cordova; CH, Chitina; CI, Cook Inlet; CMF, Castle Mountain fault; H, Homer; HI, Hinchinbrook Island; IB, Icy Bay; KI, Kayak Island; P, Palmer; PWS, Prince William Sound; S, Sutton; WR, Waxell Ridge; YB, Yakutat Bay. Stars indicate Quaternary voleanoes.

ing this period, all within the Aleutian Benioff zone west and north of Cook Inlet.

Below $30 \mathrm{~km}$ depth, the seismicity is dominated by the northwestward-dipping Aleutian Benioff zone (fig. 52). Concentrations of activity in the Benioff zone north of Anchorage, beneath Mt. Iliamna, and beneath the mapped western termination of the Denali fault are persistent features that characterize this segment of the subducted Pacific plate. Only one event was located within the weakly active, NNE-dipping Benioff zone recently identified by Stephens and others (1984) south of the Wrangell volcanoes, but this event was too small to be included in figure 52 .

Epicenters of shocks shallower than $30 \mathrm{~km}$ depth and larger than magnitude 1 are shown in figure 53. West of about longitude $148^{\circ} \mathrm{W}$., nearly all events occur within the overriding North American plate. The rate of activity within the overriding plate is low compared to that of the Benioff zone in the upper part of the subducting Pacific plate. The most prominent feature in the distribution of the shallow seismicity is aftershock activity from the August 14, 1984, earthquake near Sutton. The plotted data are not homogeneous below magnitude 2; areas of special study marked by numerous magnitude 1 events are apparent, and include the volcanic arc west of Cook Inlet, the southern Kenai Peninsula, and the Anchorage region. In general, the crustal activity is not concentrated along the mapped traces of major faults. In fact, the Sutton earthquake is the first shallow event that can be unequivocally associated with a major mapped fault since the regional network began recording in 1971 .

North of Prince William Sound two concentrations of events occur in the shallow seismicity (fig. 53). The tight cluster of events along the northern margin of Prince William Sound is due to continuing aftershock activity from the 1983 Columbia Bay shocks (Page and others, 1985), which are attributed to normal slip on a NNE-striking fault within the subducted Pacific plate. A more diffuse concentra- 


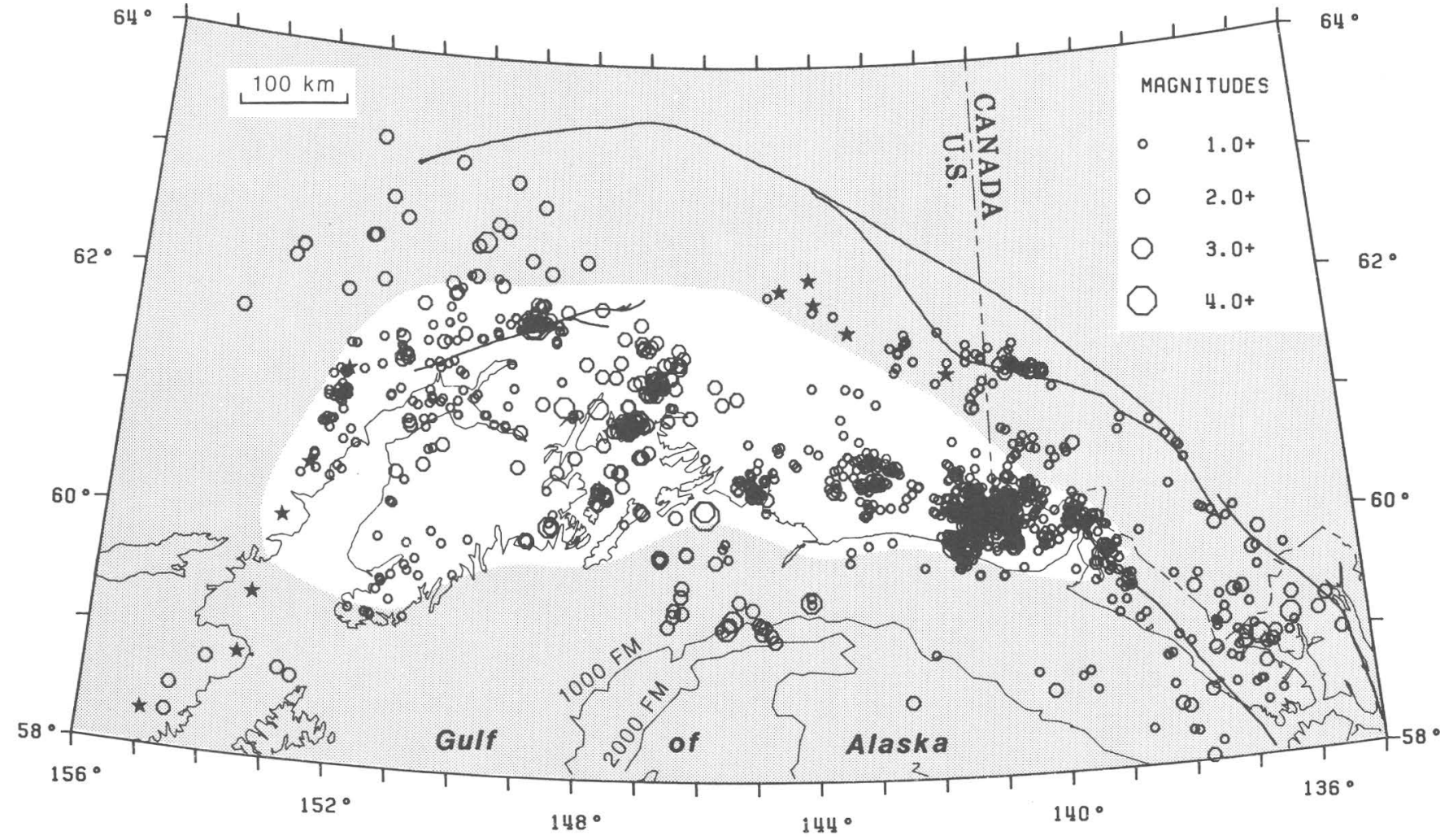

Figure 53.--Epicenters determined from the USGS seismograph network in southern Alaska for 1,598 earthquakes with coda-duration magnitude 1 and larger and depths less than $30 \mathrm{~km}$ that occurred in the period October 1983-September 1984. Symbol size varies with magnitude as indicated (note that magnitude scale is different from that used in figure 52). See figure 52 for description of map features.

tion of events located about $40 \mathrm{~km}$ to the northeast has a similar trend, but is of fset from the strike of the Columbia Bay aftershock zone. In October 1983, a magnitude $4.2 \mathrm{~m}_{\mathrm{b}}$ shock occurred at a depth of $43 \mathrm{~km}$ within the more northerly zone (fig. 52). A preliminary focal mechanism for this event determined from first motions of P-waves recorded at regional stations is compatible with normal faulting on a NE-striking plane, similar to the type of faulting inferred for other nearby events at comparable depths (for example, Stephens and others, 1985) and to the Columbia Bay events.

East of longitude $146^{\circ} \mathrm{W}$., the apparent high rate of shallow activity is due at least in part to a lower magnitude threshold used in selecting events for processing. In contrast to the region west of Prince William Sound, many of the earthquakes in the east, such as the prominent concentration of activity within the 1979 St. Elias aftershock zone north of Icy Bay, occur on a low-angle thrust that may be the interface between the North American plate and either the underthrusting Pacific plate or the colliding Yakutat block. Well-located events from the St. Elias area indicate that the crust above the thrust interface is also seismically active, but the rate of activity is low compared to that along the interface. In other areas, such as the Waxell Ridge area about $75 \mathrm{~km}$ west of the St. Elias aftershock zone, the nature of the activity is less certain because of a lack of depth control. Nonetheless, the broad distribution of this activity is similar to that observed within the St. Elias region, and it is possible that the Waxell Ridge activity occurs along that same thrust interface. The Waxell Ridge seismicity occurs near the center of the Yakataga seismic gap, which extends westward from the western limit of the St. Elias aftershock zone to the eastern extent of the 1964 rupture near the longitude of Kayak Island, and which is a site where a large $\left(M_{S} \geq 7\right)$ thrust earthquake is expected within the next two or three decades (McCann and others, 1980). Over the past ten years, the spatial distribution of microearthquake activity in and around the gap has been remarkably stable, and, other than a decay in the rate of aftershocks from the St. Elias earthquake, the rates of activity during this recent time period do not differ markedly from those observed over the past decade. Concentrations of earthquakes are observed along the Fairweather fault north and east of Yakutat Bay and along the western section of the Duke River fault, but the earthquake hypocenters are not 
sufficiently well constrained to associate the seismicity with particular mapped fault traces. The diffuse character east of longitude $138^{\circ} \mathrm{W}$. and south of latitude $59.5^{\circ} \mathrm{N}$. is at least partially attributable to this area being outside the seismograph network.

\section{REFERENCES CITED}

Lahr, J. C., Page, R. A., Fogleman, K. A., and Stephens, C. D., 1985, New evidence for activity of the Talkeetna segment of the Castle Mountain-Caribou fault system: the 1984 Sutton earthquake, in Bartsch-Winkler, Susan, ed., The United States Geological Survey in Alaska-Accomplishments during 1984: U.S. Geological Circular 967, this volume.

McCann, W. R., Perez, O. J., and Sykes, L. R., 1980, Yakataga seismic gap, southern Alaska: Seismic history and earthquake potential: Science, v. 207, p. 1309-1314.

Page, R. A., Stephens, C. D., Fogleman, K. A., and Maley, R. P., 1985, The Columbia Bay, Alaska, earthquakes of 1983, in Bartsch-Winkler, Susan, and Reed, K. M., eds., The United States Geological Survey in Alaska-Accomplishments during 1983: U.S. Geological Survey Circular 945, p. 80-83.

Stephens, C. D., Fogleman, K. A., Lahr, J. C., and Page, R. A., 1984, Wrangell Benioff zone, southern Alaska: Geology, v. 12, p. 373-376.

Stephens, C. D., Fogleman, K. A., Page, R. A., and Lahr, J. C., 1985, Seismicity in southern Alaska, October 1982-September, 1983, in Bartsch-Winkler, Susan, and Reed, K. M., eds., The United States Geological Survey in Alaska-Accomplishments during 1983: U.S. Geological Survey Circular 945, p. 83-86.

Reviewers: F. W. Lester and R. A. White

\section{SOUTHEASTERN ALASKA}

(Figure 54 shows study areas described.)

\section{SOUTHEASTERN ALASKA COINCIDENT ZONE}

\section{David A. Brew and Arthur B. Ford}

This report calls attention to an unusual geographic coincidence of major linear geologic features in a narrow zone that extends the length of southeast Alaska and southward into British Columbia (fig. 54). Eight major geologic features define the zone: (1) the Gravina sequence of flysch and intermediate and mafic volcanic rocks of Late Jurassic and Early Cretaceous age; (2) the KlukwanDuke plutonic belt of ultramafic bodies of $100-110$ Ma age; (3) the Admiralty-Revillagedo belt of epidote-bearing granitic plutons of 90 Ma age; (4) the Wrangell-Revillagigedo belt of Barrovian metamorphic rocks of Cretaceous and earliest Ter-

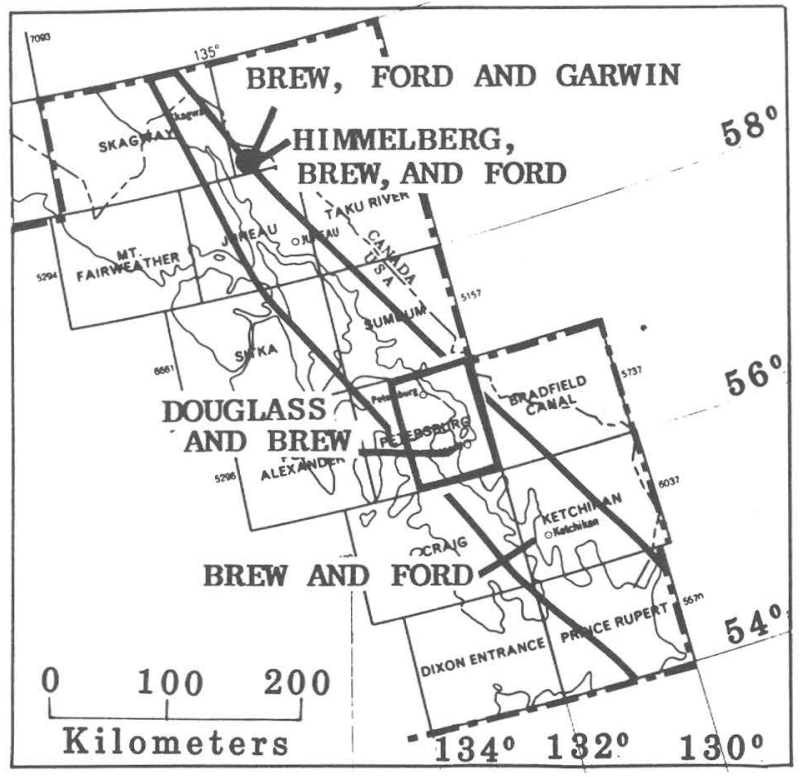

Figure 54.--Map showing areas in southeastern Alaska discussed in this circular.

tiary age; (5) the tonalite sill belt of foliated granitic intrusions of 60-70 Ma age; (6) a major linear aeromagnetic high; (7) a major linear gravity gradient; and (8) the Coast Range megalineament. Features 5 through 8 have been discussed by Brew and Ford (1978). All of these features are shown on figure 55. In addition, there is a high frequency of mineral deposits within the coincident zone defined by the eight major features (Berg and others, 1981). Brew and Ford (1984) imply that this is related primarily to metamorphic effects, but it may also reflect in part the same fundamental causes as do the other features in the zone.

The Gravina sequence (fig. 55a) is an appropriate term for the Gravina part of the GravinaNutzotin belt of Berg and others (1972). It consists of rock units with the following lithologies: (1) graywacke; (2) intermediate to mafic volcanic breccia, tuff, and flows; (3) some interlayered mudstone; and (4) some conglomerate. The sequence is Late Jurassic and early Cretaceous in age. Although later deformation and metamorphism have severely modified the original configuration of the belt, it seems likely that it was originally a relatively long and narrow trough filled from both sides. Monger and others (1982) contend that it is an interplate basin that has been squeezed between the Alexander and the Stikine terranes during a major collision event; Ford and Brew (1978) and Brew and Ford (1983) suggest that it is an intraplate rift basin that was deformed during the Cretaceous subduction of the Chugach terrane $100 \mathrm{~km}$ to the west.

The Klukwan-Duke belt (fig. 55a), of mafic and ultramafic rocks of 100-110 Ma (Lanphere and Eberlein, 1966), was defined by Brew and Morrell (1983), but its unusual character had been recogniz- 

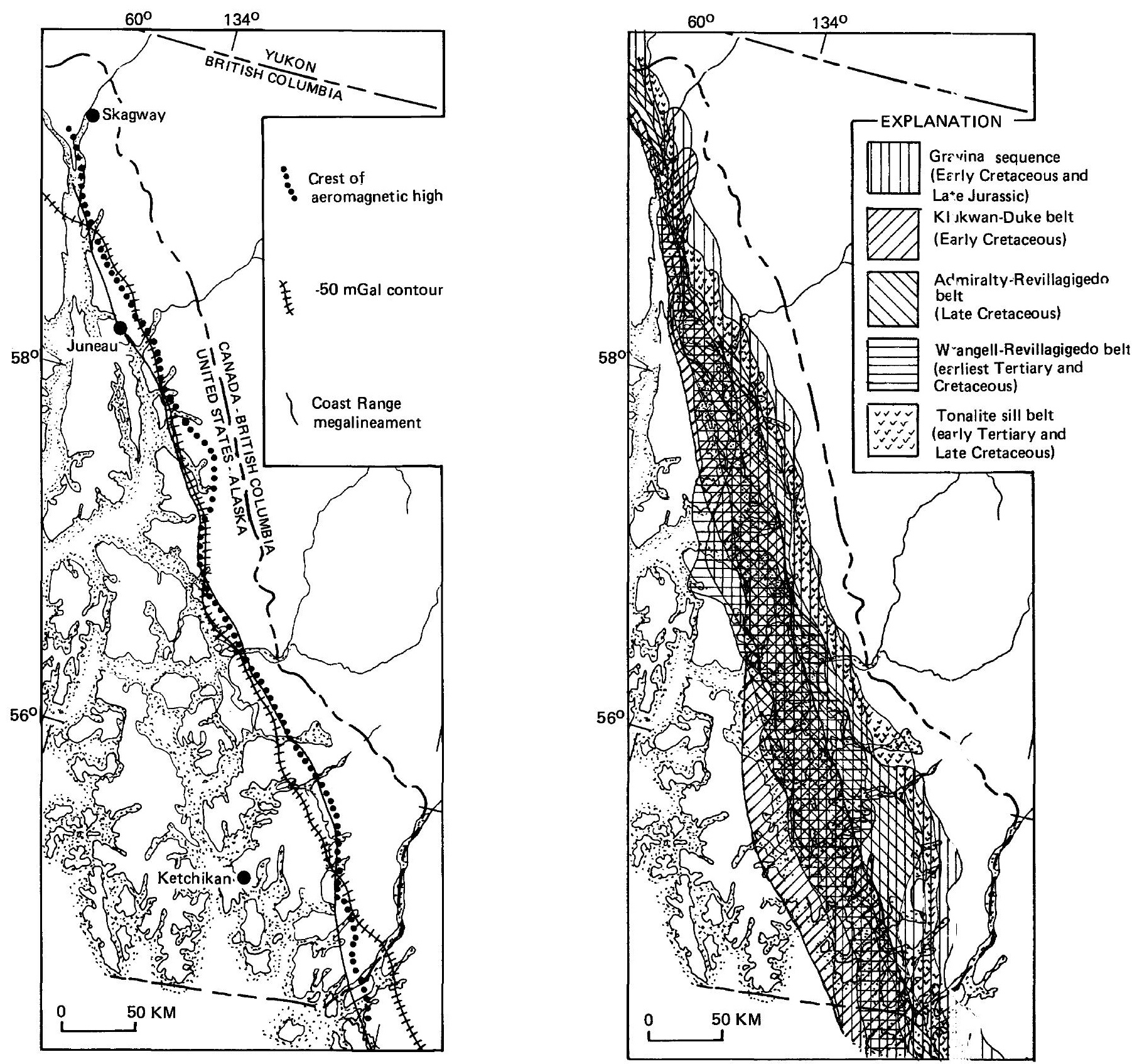

Figure 55.--The coincident zone of southeastern Alaska and part of British Columbia, Canada. (A) Juxtaposition of five of the eight major geologic features in the coincident zone. (B) The -50 mGal gravity contour, crest of the persistent aeromagnetic high, and Coast Range megalineament, in the southeastern Alaska coincident zone. 
ed by Taylor and Noble (1960) and Taylor (1967). They, along with Irvine (1973) and Murray (1972), subscribe to a sub-crustal origin for these Alaskantype or concentrically zoned bodies. More than 30 separate bodies are scattered along strike in the 50$\mathrm{km}$ width of the belt.

The Admiralty-Revillagigedo belt (fig. 55a) of 90 Ma plutons was first described by Brew and Morrell (1983) and has since been the focus of detailed studies by Burrell (1984a, b, c) and by Zen and Hammerstrom (1984a, b). This belt extends from perhaps north of southeastern Alaska south to include the Ecstall pluton near Prince Rupert, British Columbia (Woodsworth, 1983). The abundance of plutons in the generally $70-\mathrm{km}$-wide belt varies appreciably along strike (Brew and Morrell, 1983).

The Wrangell-Revillagigedo belt (fig. 55a) of metamorphic rocks was first recognized by Buddington and Chapin (1929) and has since been described in some detail for the Juneau area (Forbes, 1959; Ford and Brew, 1977; Himmelberg and others, 1984a, b), and near Wrangell (Douglass and Brew, 1985). Although locally variable and complex, the belt is generally a consistent feature with a welldefined Barrovian sequence increasing in grade from prehnite-pumpellyite facies on the west to sillimanite-grade amphibolite facies on the east. The same belt of rocks occurs to the south in British Columbia, where it has been studied by Crawford and Hollister (1982). The belt is closely linked in time and space to the tonalite sill belt of plutons, indicating that relatively uniform metamorphic conditions prevailed in an unusually long, narrow zone at the time of intrusion (Brew and Ford, 1981).

The tonalite sill belt of foliated plutons (fig. 55a) has been described by Brew and Morrell (1983), Brew and Ford (1981), and Ford and Brew (1981) and is shown on the map of Brew and Morrell (1980). It consists of a remarkably long, narrow, locally discontinuous belt of sheet- or sill-like plutons of dominantly tonalitic composition that were emplaced at 69-62 Ma (Gehrels and others, 1984). Wider segments of the 3-25 km-wide belt consist of 1-3 individual sills separated by screens of gneiss and migmatite. The belt extends south at least to Prince Rupert (Crawford and Hollister, 1982). Brew and Ford $(1978,1981)$ suggest that the sill belt was intruded along some kind of important structural discontinuity.

The major linear aeromagnetic high (fig. 55b) (Brew and Ford, 1978; Decker, 1979) is an obvious, but usually discontinuous, high that is close to the outcrop of the sill belt. Jachens (1984) and Griscom (1977) both suggest that the sill extends to depths of $3-8 \mathrm{~km}$ or more. This aeromagnetic lineament is the northern continuation of the major feature mapped along the coast of British Columbia by Haines and others (1974).

A relatively steep gravity gradient more or less parallels the aeromagnetic lineament (fig. 55b). The gradient separates the -20 to $-50 \mathrm{mGal}$ field to the west from the -80 to $-110 \mathrm{mGal}$ field to the east over the Coast Mountains (Brrnes, 1976). Barnes interprets the gradient to be caused by crustal thickening to the east, influence of uncorrected terrain effects, and(or) a possible eastward decrease in rock densities.

The Coast Range megalineament (Brew and Ford, 1978) is a nearly continuous, prominent topographic feature that extends from north of Juneau to south of Prince Rupert, B.C (fig. 55b). It is a zone from a few hundred meters to $10 \mathrm{~km}$ wide that is caused by selective erosion along closely spaced joints, foliation, compositional layering, and small faults. In a few areas, such as Work Channel near Prince Rupert, it is a major fault (Crawford and Hollister, 1982). Brew and Ford (1978) speculated that the megalineament was the surface expression of the concealed western contact, at cepth, of the granitoid intrusive rocks and high-grade metamorphic rocks of the central zones of the Coast plutonic-metamorphic complex (Brew and Ford, 1984) with the schists of the western metamorphic zone.

A few Quaternary volcanic piles located in or near the coincident zone (Brew and others, 1984, 1985; Beikman, 1975) indicate the continuing existence of deep fractures. R. B. Forbes (oral commun., 1984) has found eclogite nodules in one of these volcanic units on Kupreanof Islant, indicating a deep origin for some of the volcanic riscks.

We do not have a ready explanation for this coincident zone, but several of the features are clearly interrelated. Discussion of these relations is beyond the scope of this short article. Most of the features could be controlled by either a persistent large fracture zone that extends through the earth's crust or by features related to that zon?.

\section{REFERENCES CITED}

Barnes, D. F., 1976, Bouguer gravity map of Alaska: U.S. Geological Survey Open-File Report 76-70, scale 1:2,500,000.

Beikman, H. M., 1975, Preliminary geologic map of southeastern Alaska: U.S. Geolorical Survey Miscellaneous Field Studies Map MF-673, 2 sheets, scale $1: 1,000,000$.

Berg, H. C., Decker, J. E., and Abramson, B. S., 1981, Metallic mineral deposits of southeastern Alaska: U.S. Geological Surve`y Open-File Report 81-122, 136 p., 1 map, scale $1: 1,000,000$.

Berg, H. C., Jones, D. L., and Richter, D. H., 1972, Gravina-Nutzotin belt-Tectonic significance of an upper Mesozoic sedimentary and volcanic sequence in southern and southeastern Alaska, in Geological Survey research 1972: U.S. Geological Survey Professional Paץor 800-D, p. D1-D24.

Brew, D. A., and Ford, A. B., 1978, Megalineament in southeastern Alaska marks southwest edge of Coast Range batholithic complex: Canadian Journal of Earth Science, v. 15, no. 11, p. 17631772. 
Brew, D. A., and Ford, A. B., 1981, The Coast plutonic complex sill, southeastern Alaska, in Albert, N. R. D., and Hudson, Travis, eds., The United States Geological Survey in Alaska-Accomplishments during 1979: U.S. Geological Survey Circular 823-B, p. B96-B99.

Brew, D. A., and Ford, A. B., 1983, Comment on Monger, J. W. H., Price, R. A., and Tempelman-Kluit, D. J., 1982, Tectonic accretion and the origin of the two major metamorphic and plutonic welts in the Canadian Cordillera: Geology, v. 11, p. 427429.

Brew, D. A., and Ford, A. B., 1984, The northern Coast plutonic complex, southeastern Alaska and northwestern British Columbia, in Coonrad, W. L., and Elliott, R. L., eds., The United States Geological Survey in Alaska-Accomplishments during 1981: U.S. Geological Survey Circular 868, p. 120-124.

Brew, D. A., Karl, S. M., and Tobey, E. F., 1985 , Reinterpretation of age of Kuiu-Etolin belt volcanic rocks, Kupreanof Island, southeastern Alaska, in Bartsch-Winkler, Susan, and Reed, K. M., eds., The United States Geological Survey in Alaska-Accomplishments during 1983: U.S. Geological Survey Circular 945, p. 86-88.

Brew, D. A., and Morrell, R. P., 1980, Preliminary map of intrusive rocks in southeastern Alaska: U.S. Geological Survey Miscellaneous Field Studies Map MF-1048, 1 sheet, scale $1: 1,000,000$.

Brew, D. A., and Morrell, R. P., 1983, Intrusive rocks and plutonic belts of southeastern Alaska, USA, in Roddick, J. A., ed., Circum-Pacific plutonic terranes: Boulder, Colo., Geological Society of America Memoir 159, p. 171-193.

Brew, D. A., Ovenshine, A. T., Karl, S. M., and Hunt, S. J., 1984, Preliminary reconnaissance geologic map of the Petersburg and parts of the Port Alexander and Sumdum 1:250,000 quadrangles, southeastern Alaska: U.S. Geological Survey Open-File Report 84-405, 2 sheets, 43 p., pamphlet.

Buddington, A. F., and Chapin, Theodore, 1929, Geology and mineral deposits of southeastern Alaska: U.S. Geological Survey Bulletin 800 , 398 p.

Burrell, P. D., 1984a, Cretaceous plutonic rocks, Mitkof and Kupreanof Islands, Petersburg quadrangle, southeastern Alaska, in Coonr d, W. L., and Elliott, R. L., eds., The United States Geological Survey in Alaska-Accomplishments during 1981: U.S. Geological Survey Circular 868, p. 124-126.

Burrell, P. D., 1984b, Late Cretaceous plutonic rocks, Petersburg quadrangle, southeast Alaska, in Reed, K. M., and Bartsch-Winkler, Susan, eds., The United States Geological Survey in Alaska-Accomplishments during 1982: U.S. Geological Survey Circular 939, p. 93-96.
Burrell, P. D., 1984c, Map and table descri ing the Admiralty-Revillagigedo intrusive belt plutons in the Petersburg 1:250,000 quadrangle, southeastern Alaska: U.S. Geological Survey OpenFile Report 84-171, 1 sheet, 6 p., pampl let.

Crawford, M. L., and Hollister, L. S., 1982, Contrast of metamorphic and structural histories across the Work Channel lineament, Coast Plutonic Complex, British Columbia: Journal of Geophysical Research, v. 87, p. 3849-3860.

Crawford, M. L., and Hollister, L. S., 1983, Correction to "contrast of metamorphic and structural histories across the Work Channel lineament, Coast plutonic complex, British Columbia: Journal of Geophysical Research, v. 88, p. 10,645-10,640.

Decker, J. E., 1979, Preliminary aeromagnetic map of southeastern Alaska: U.S. Geological Survey Open-File Report 79-1694.

Douglass, S. L., and Brew, D. A., 1985, Pclymetamorphism in the eastern part of the Petersburg map-area, southeastern Alaska, in BartschWinkler, Susan, ed., The United States Geological Survey in Alaska-Accomplishment:- during 1984: U.S. Geological Survey Circular 967, this volume.

Forbes, R. B., 1959, The bedrock geology and petrology of the Juneau Icefield area, southeastern Alaska: Seattle, University of Washington, Ph.D. dissertation, $265 \mathrm{p}$.

Ford, A. B., and Brew, D. A., 1977, Trunc?tion of regional metamorphic zonation pattern of the Juneau, Alaska, area of the Coast Rang? batholith, in Blean, K. M., ed., The United States Geological Survey in Alaska-Accomplishments during 1976: U.S. Geological Survey Circular 752-B, p. B85-B87.

Ford, A. B., and Brew, D. A., 1978, Minor-metal content of Cretaceous greenstone near Juneau, Alaska, in Johnson, K. M., ed., The United States Geological Survey in Alaska-Accomplishments during 1977: U.S. Geological Survey Circular 772-B, p. B85-B88.

Ford, A. B., and Brew, D. A., 1981, Orthogneiss of Mount Juneau-an early phase of Coast Mountain plutonism involved in Barrovian regional metamorphism near Juneau, in Albert, N. R. D., and Hudson, Travis, eds., The United States Geological Survey in Alaska-Accomplishments during 1979: U.S. Geological Survey Circular 823-B, p. B99-B102.

Gehrels, G. E., Brew, D. A., and Saleeby, J. B., 1984, Progress report on $\mathrm{U} / \mathrm{Pb}$ (zircon) geochronologic studies in the Coast F'utonicmetamorphic complex east of Juneau, southeastern Alaska, in Bartsch-Winkler, Susan, and Reed, K. M., eds., The United States Geological Survey in Alaska-Accompli-hments during 1982: U.S. Geological Survey Circular 939, p. 100-102. 
Griscom, Andrew, 1977, Interpretation of aeromagnetic data, in Berg, H. C., and others, eds., Mineral resources of the Granite Fiords wilderness study area: U.S. Geological Survey Bulletin $1403,151 \mathrm{p}$.

Haines, G. V., Hanneford, W., and Riddihough, R. P., 1974, Magnetic anomalies over British Columbia and the adjacent Pacific Ocean: Canadian Journal of Earth Sciences, v. 8, p. 387-391.

Himmelberg, G. R., Ford, A. B., and Brew, D. A., $1984 \mathrm{a}$, Progressive metamorphism of pelitic rocks in the Juneau area, southeastern Alaska, in Coonrad, W. L., and Elliott, R. L., eds., The United States Geological Survey in Alaska-Accomplishments during 1981: U.S. Geological Survey Circular 868, p. 131-134.

Himmelberg, G. R., Ford, A. B., and Brew, D. A., $1984 \mathrm{~b}$, Reaction isograds in pelitic rocks of the Coast plutonic-metamorphic complex near Juneau, Alaska, in Bartsch-Winkler, Susan, and Reed, K. M., eds., The United States Geological Survey in Alaska-Accomplishments during 1982: U.S. Geological Survey Circular 939, p. 105-108.

Irvine, T. N., 1973, Bridget Cove Volcanics, Juneau area, Alaska; possible parental magma of Alaskan-type ultramafic complexes: Carnegie Institute, Washington, Yearbook 1972. p.478490.

Jachens, R. C., 1984, Interpretation of the aeromagnetic data, in U.S. Geological Survey and U.S. Bureau of Mines, Mineral resources of Tracy Arm-Fords Terror wilderness study area and vicinity, Alaska: U.S. Geological Survey Bulletin 1525, p. 7-18.

Lanphere, M. A., and Eberlein, G. D., 1966, Potassium-argon ages of magnetite-bearing ultramafic complexes in southeastern Alaska (abs.): Geological Society of America Special Paper 87, p. 94.

Monger, J. W. H., Price, R. A., and TempelmanKluit, D. J., 1982, Tectonic accretion and the origin of the two major metamorphic and plutonic welts in the Canadian Cordillera: Geology, v. 10, p. 70-75.

Murray, C. G., 1972, Zoned ultramafic complexes of the Alaskan type: feeder pipes of andesitic volcanoes: Geological Society of America Memoir 132, p. 313-335.

Taylor, H. P., 1967, The zoned ultramafic complexes of southeastern Alaska, in Wyllie, P. J., ed., Ultramafic and related rocks: New York, John Wiley and Sons, Inc., p. 97-121.

Taylor, H. P., Jr., and Noble, J. A., 1960, Origin of the ultramafic complexes in southeastern Alaska: International Geological Congress, 21st, Copenhagen, Reports, 13, p. 175-187.

Woodsw orth, G. J., Loveridge, W. D., Parrish, R. R., and Sullivan, R. W., 1983, Uranium-lead dates from the Central Gneiss Complex and Ecstall
Pluton, Prince Rupert map-area, British Columbia: Canadian Journal of Earth Sciences, v.20, p. $1475-1483$.

Zen, E-an, and Hammerstrom, J. M., 1984a, Magmatic epidote and its petrologic significance: Geology, v. 12, p. 515-518.

Zen, E-an, and Hammerstrom, J. M., 1984b, Mineralogy and a petrogenetic model for the tonalite pluton at Bushy Point, F.evillagigedo Island, Ketchikan $1^{\circ} \times 2^{\circ}$ quadrangle, southeastern Alaska, in Reed, K. M., and Bartsch-Winkler, Susan, eds., The United States Geological Survey in Alaska-Accomplishments during 1982: U.S. Geological Survey Circular 939, p. 118-123.

Reviewers: S. E. Box and W. H. Nelson

\section{FOSSILIFEROUS MIDDLE AND (OR) UPPER TRIASSIC ROCKS WITHIN T:TE COAST PLUTONIC-METAMORPHIC COMPLEX SOUTHEAST OF SKAGWA?}

\section{David A. Brew, Arthur B. Fo-d and Steven L. Garwin}

The age of the protoliths of the metamorphic rocks within the Coast plutonic-metamorphic complex as defined by Brew and Ford (1984a) is uncertain for much of the complex. We report here the first collection of fossils from the central metamorphic zone of the Coast plutonic-metamorphic complex, establishing a Triassic age for at least part of the protolith of that zone and provides information of critical value in tectonic interpretation of the region. The western metamorphic zone of the Coast plutonic-metamorphic complex contains fossils of Permien, Triassic, Jurassic, and Cretaceous age (Ford and Brew, 1973, 1977; Brew and Ford, 1977; Loney, 1964). The eastern metamorphic zone contains fossils of Permian age in the Bradfield Canal area (R. L. Elliott, USGS, oral commun., 1980). Permian and Triassic fossils occur not far to the east of the eastern metamorphic zone in British Columbia (Souther, 1971; Aitken, 1959). Fossils have not been reported previously from the central metamorphic and central granitic zones, though suppositions about the ages of the zones are an important part of some tectonostratigraphic interpretaticns (Berg and others, 1978). Abundant $\mathrm{K}-\mathrm{Ar}$ data (Wilson and others, 1979; J. G. Smith, USGS, written commun., 1976) and one $140 \mathrm{Ma}$ zircon date (Smith and others, 1979) document the intrusive history of the complex.

Geologic mapping in the Atlin A-8 1:63,360 quadrangle during 1984 revealed an area of only slightly metamorphosed rocks adjacent to the upper Meade Glacier (fig. 56). This is referred to, for convenience, as the Meade Glacier section. The occurrence of these low-grade rocks within the generally high-grade central zone of the Coast plutonic-metamorphic complex may be best 


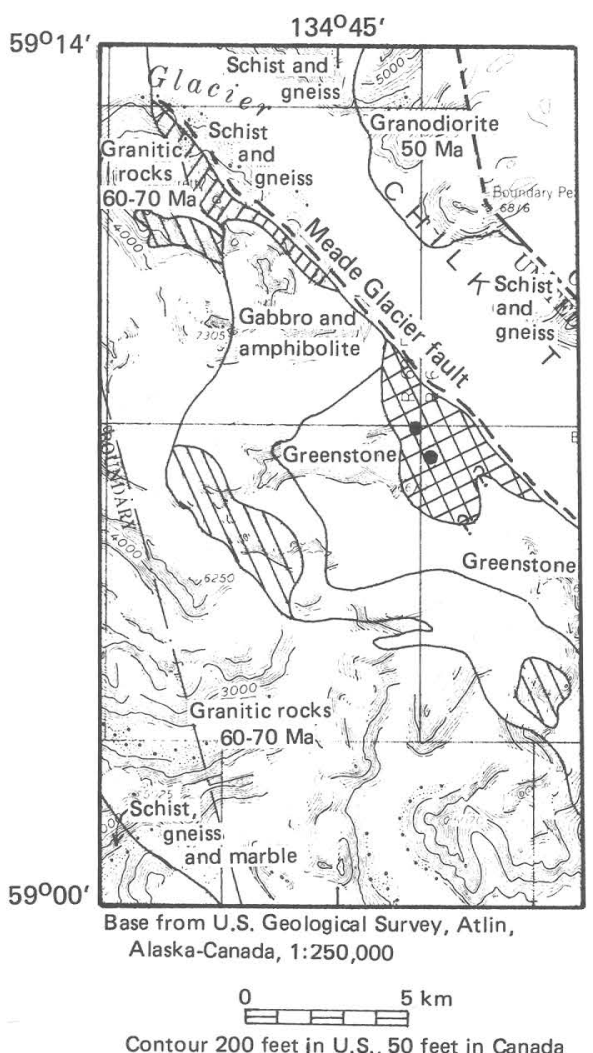

\section{EXPLANATION}

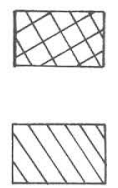

Area underlain by volcanic and fossiliferous carbonate rocks, turbidites and mudstone (Triassic)

Peridotite (Himmelberg and others, 1985) (Cretaceous?)

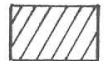

Tectonized ultramafic rocks and some schist (Himmelberg and others, 1985) (Cretaceous?)

Rock types dominant in other areas shown by labels

- Fossiliferous sections

Figure 56.--Location of the fossiliferous section near the Meade Glacier, the ultramafic mass to the west, and the major geologic features. Base map from U S G S 1:250,000 series Atlin quadrangle.

explained by these rocks not having been uplifted and, thus, eroded away as were comparable parts of the complex elsewhere. This fossiliferous section indicates that Triassic rocks were protoliths for the Coast plutonic-metamorphic complex when it formed during latest Cretaceous and Tertiary time (Monger and others, 1982; Brew and Ford, 1983, $1984 \mathrm{~b}, \mathrm{c})$.

The Meade Glacier section is located on two east-trending spurs of the mountain mass that is

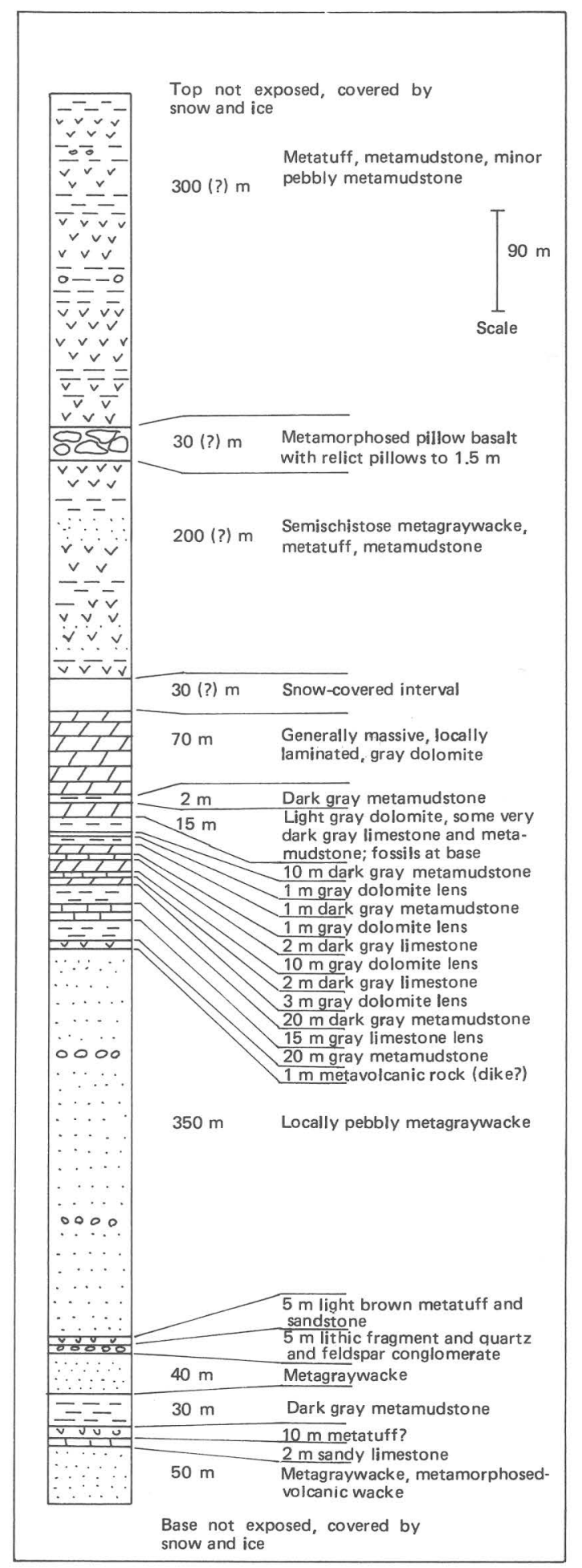

Figure 57.--Diagrammatic stratigraphic column for fossiliferous section, upper Meade Glacier area, Atlin A-8 quadrangle. Thicknesses estimated; thicknesses of thinner units are exaggerated. 
underlain mostly by the ultramafic body described by Himmelberg and others (1985). The relation of the fossiliferous section to the adjacent rock units is uncertain. As shown on figure 56, the section is bounded on the west by a massive greenstone unit and on the east by an inferred fault under the Meade Glacier. The relation on the west is not well understood because of extensive snow and ice cover, under which the contact may be a fault. This is suggested by the occurrence of abundant biotite schist float close to the fossiliferous rocks on the northern of the two spurs. The fault on the east is in part beneath Meade Glacier; it is indicated both by the presence of a polydeformed and polymetamorphosed unit on the opposite side of Meade Glacier and by a fault zone to the north. It is possible, however, that the fossiliferous section rests unconformably on the multiply deformed unit, which is tentatively correlated with the pre-Upper Triassic unit near the Tulsequah area in British Columbia (Souther, 1971).

The section (fig. 57) consists mostly of volcanic and carbonate rocks, turbidites, and mudstones, with carbonate rocks most common in the middle of the section and volcanics more common near the top. The section strikes northwest and is overturned, with steep to moderate dips to the southwest. Approximately $1,225 \mathrm{~m}$ of section is exposed. The uppermost part was not studied as carefully as the lower, fossiliferous, part. The direction of younging is based on rare graded beds in the lower, sedimentary, part and on well-developed pillows in the upper, more volcanic, part of the section. Details of the section based on the exposures on the southernmost spur are shown on figure 57. Most of the thin carbonate units occur as lenses within dark-gray metamudstone. All of the rock types exposed on the northern spur are also found somewhere on the southern spur, but the exact stratigraphic and structural relations are not known: both exhibit abrupt facies changes.

Fossils were collected from carbonate rocks on both spurs. A well preserved ammonite found in coleoid-rich dark-gray limestone collected in the northern spur is late Middle Triassic to early Late Triassic in age (N. J. Silberling, USGS, oral commun., 1984). Conodonts from the same sample are of the same age (K. E. Denkler and A. G. Harris, USGS, written commun., 1985). The only other occurrence of Triassic fossils as old in southeastern Alaska is at George Inlet on Revillagigedo Island, about $450 \mathrm{~km}$ south (Silberling and others, 1982). Fossils of the same age occur in the Chutine and Telegraph Creek areas in British Columbia, about $230 \mathrm{~km}$ to the southeast (Souther, 1959, 1972). Small ammonites collected from light-gray dolomite or limestone on the southern spur are not yet identified. Conodont collections from all carbonate units have not yet been processed. Fossil localities closest to the Meade Glacier section are; (1) the Late Triassic collection on the Chilkat Peninsula, 35 $\mathrm{km}$ to the west (Plafker and others, 1979); (2) the
Cretaceous plant fossil locality at Berners Bay (R. W. Brown, USGS, written commun., 1957) about 50 $\mathrm{km}$ to the southwest; and (3) the Late Triassic ammonite localities near Juneau, $110 \mathrm{~km}$ to the south (Brew and Ford, 1977; Ford and Brew, 1977).

The stratigraphic section shown in figure 57 does not correlate exactly either paleontologically or lithologically with other sections in British Columbia and southeastern Alaska, in part because it is less deformed and metamorphosed than the other sections and because of the apparent difference in age mentioned above. The upper $550 \mathrm{~m}$ of section, as a lithologic package, resembles the Upper Triassic units near Juneau (Brew and Ford, 1977; Ford and Brew, 1977) on southeastern Admiralty Island (Loney, 1964) and in the Keku Strait area (Muffler, 1967; Brew and others, 1984).

Information derived from the Meade Glacier section refines the tectonostratigraphic terrane analysis of southeastern Alaska and northern British Columbia. Berg and others (1978) include this area in their Tracy Arm terrane, which they imply is a separate, exotic, far-traveled tectonostratigraphic terrane and a separate tectonic entity. Brew and Ford $(1983,1984 \mathrm{~b})$ interpret the area instead to be the metamorphosed and deformed Alexander terrane and, thus, simply part of the Alexander-Stikine superterrane that has been subjected to later metamorphic and intrusive events (Monger and others, 1982; Brew and Ford, 1983; 1984 b,c) If the upper $550 \mathrm{~m}$ of the section is Upper Triassic and the lower $675 \mathrm{~m}$ is Middle Triassic and (or) Upper Triassic, then the section would have both paleontologic and lithologic linkages to the Triassic sections in southeastern Alaska and northern British Columbia.

\section{REFERENCES CITED}

Aitken, J. D., 1959, Atlin map-area, British Columbia: Geological Survey of Canada Memoir $307,89 \mathrm{p}$.

Berg, H. C., Jones, D. L., and Coney, P. J., 1978, Map showing pre-Cenozoic tectonostratigraphic terranes of southeastern Alaska and adjacent areas: U.S. Geological Survey Open-File Report 78-1085, 2 sheets, scale 1:1,000,000.

Brew, D. A., and Ford, A. B., 1977, Preliminary geologic and metamorphic-isograd map of the Juneau B-1 quadrangle, Alaska: U.S. Geological Survey Miscellaneous Field Studies Map MF-846, 1 sheet, scale $1: 31,680$.

Brew, D. A., and Ford, A. B., 1983, Comment on Monger, J. W. H., Price, R. A., and Tempelman-Kluit, D. J., 1982, Tectonic accretion and the origin of the two major metamorphic and plutonic welts in the Canadian Cordillera: Geology, v. 11, p. 427-429.

Brew, D. A., and Ford, A. B., 1984a, The northern Coast plutonic complex, southeastern Alaska and northwestern British Columbia, in Coonrad, 
W. L., and Elliott, R. L., eds., The United States Geological Survey in Alaska: Accomplishments during 1981--U.S. Geological Survey Circular 868, p. 120-124.

Brew, D. A., and Ford, A. B., 1984b, Tectonostratigraphic terranes in the Coast plutonic-metamorphic complex, southeastern Alaska, in Reed, K. M., and Bartsch-Winkler, Susan, eds., The United States Geological Survey in Alaska -Accomplishments during 1982: U.S. Geological Survey Circular 939, p. 90-93.

Brew, D. A., and Ford, A. B., 1984c, Timing of metamorphism and deformation in the Coast plutonic-metamorphic complex, near Juneau, Alaska (abs.): Geological Society of America Annual Meeting, Cordilleran Section, 80th, Anchorage, Alaska, May 30-31, June 1, 1984, Abstracts with Programs, v. 16, no. 5, p. 272.

Brew, D. A., Ovenshine, A. T., Karl, S. M., and Hunt, S. J., 1984, Preliminary reconnaissance geologic map of the Petersburg and parts of the Port Alexander and Sumdum 1:250,000 quadrangles, southeastern Alaska: U.S. Geological Survey Open-File Report 84-405.

Ford, A. B., and Brew, D. A., 1973, Preliminary geologic and metamorphic-isograd map of the Juneau B-2 quadrangle, Alaska: U.S. Geological Survey Miscellaneous Field Studies Map MF-527, 1 sheet, scale $1: 31,680$.

Ford, A. B., and Brew, D. A., 1977, Preliminary geologic and metamorphic-isograd map of northern parts of the Juneau A-1 and A-2 quadrangles, Alaska: U.S. Geological Survey Miscellaneous Field Studies Map MF-847, 1 sheet, scale $1: 31,680$.

Gehrels, G. E., Brew, D. A., and Saleeby, J. B., 1984, Progress report on U/Pb (zircon) geochronologic studies in the Coast plutonic-metamorphic complex east of Juneau, southeastern Alaska; in Bartsch-Winkler, Susan, and Reed, K. M., eds., The United States Geological Survey in Alaska-Accomplishments during 1982: U. S. Geological Survey Circular 939, p. 100102.

Himmelberg, G. R., Brew, D. A., and Ford, A. B., 1985, Alaskan-type ultramafic bodies in the Coast plutonic-metamorphic complex near Skagway, southeastern Alaska, in BartschWinkler, Susan, ed., The United States Geological Survey in Alaska-Accomplishments during 1984-U.S. Geological Survey Circular 967 (this volume).

Loney, R. A., 1964, Stratigraphy and petrography of the Pybus-Gambier area, Admiralty Island, Alaska: U.S. Geological Survey Bulletin 1178, $103 \mathrm{p}$.

Monger, J. W. H., Price, R. A., and TempelmanKluit, D. J., 1982, Tectonic accretion and the origin of the two major metamorphic plutonic welts in the Canadian Cordillera: Geology, v. 10, p. 70-75.

Muffler, L. J. P., 1967, Stratigraphy of the Keku Is- lets and neighboring parts of Kuiu and Kupreanof Islands, southeastern Alaska: U.S. Geological Survey Bulletin 1241-C, p. C1-C52.

Plafker, George, Hudson, T. L., and Silberling, N. J., 1979, Late Triassic fossils from a sequence of volcanic and sedimentary rocks on the Chilkat Peninsula, southeastern Alaska, in Johnson, K. M., and Williams, J. R., eds., The United States Geological Survey in Alaska-Accomplishments during 1978-U.S. Geological Survey Circular 804-B, p. B107-B110.

Silberling, N. J., Wardlaw, B. R., and Berg, H. C., 1982, New paleontologic age determinations from the Taku terrane, Ketchikan area, southeastern Alaska, in Coonrad, W. L., ed., The United States Geological Survey in Alaska: Accomplishments during 1980-U.S. Geological Survey Circular 844, p. 117-119.

Smith, J. G., Stern, T. W., and Arth, J. G., 1979, Isotopic ages indicate multiple episodes of plutonism and metamorphism in the Coast Mountains near Ketchikan, Alaska (abs.): Geological Society of America Abstracts with Programs, v. 11 , no. 7 , p. 519 .

Souther, J. G., 1959, Chutine, Cassiar District, British Columbia: Geological Survey of Canada Map 7-1959.

Souther, J. G., 1971, Geology and ore deposits of Tulsequah map area, British Columbia: Geological Survey of Canada Memoir 362, 84 p., 1 pl., scale $1: 250,000$.

Souther, J. G., 1972, Telegraph Creek Map-area, British Columbia: Geological Survey of Canada Paper 71-44.

Wilson, F. H., Dadisman, S. V., and Herzon, P. L., 1979, Map showing radiometric ages of rocks in southeastern Alaska: U.S. Geological Survey Open-File Report 79-594, 33 p., 1 sheet, scale 1:1,000,000.

Reviewers: Belå Csejtey, Jr., and J. R. Williams

\section{POLYMETAMORPHISM IN THE EASTERN PETERSBURG QUADRANGLE, SOUTHEASTERN ALASKA}

\section{Susan L. Douglass and David A. Brew}

Evidence for five episodes of regional and contact metamorphism has been found in the eastern part of the Petersburg quadrangle. This report summarizes the spatial distribution and mineralogic and textural characteristics of each episode. Our petrographic data and geologic evidence (Brew and others, 1984) can be interpreted in terms of the following metamorphic history: (1) prehnite-pumpellyite to greenschist facies regional metamorphism of graywacke and associated rocks of early Late Cretaceous age; (2) thermal metamorphism in aureoles of Alaskan-type mafic and ultramafic intru- 


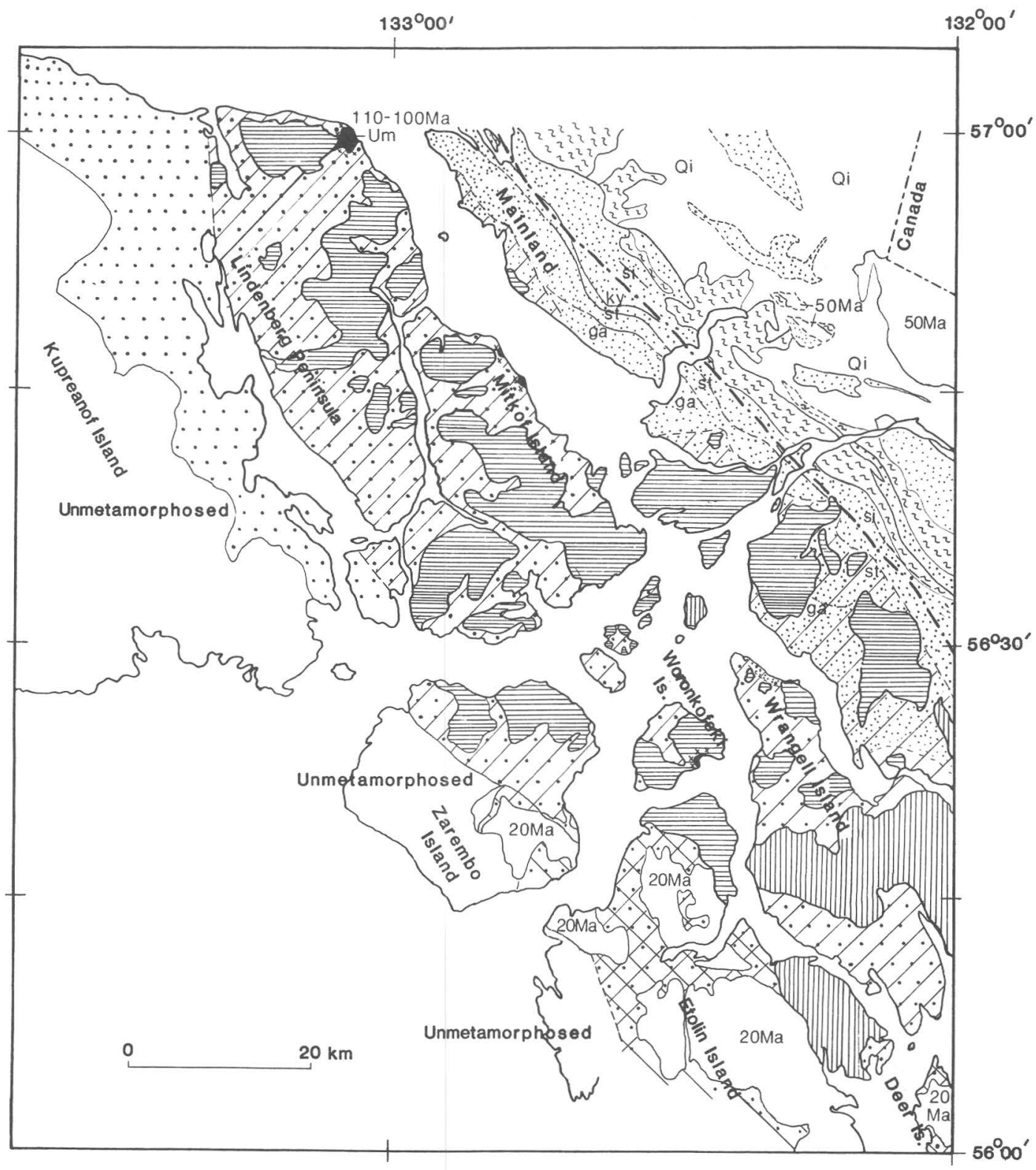

EXPLANATION

$\because$ Pre-110 Ma low-grade metamorphism

$90 \mathrm{Ma}$ low-grade regional thermal

metamorphism

$90 \mathrm{Ma}$ pluton with or without $A D$ and SI in aureole

90 Ma pluton with KY in aureole

100-110 Ma "A1aska-type" intrusions ( $x$ 's indicate aureole)
Mainland Barrovian metamorphism

? Tonalite sill belt of intrusive rocks 22 and migmatite

A $20 \mathrm{Ma}$ regional thermal aureoles

$\lceil$ Coast Range megalineament

Barrovian "ga" garnet, "st" staurolite, 93:- "ky" kyanite, "si" sillimanite isograds

Figure 58.--Distribution of metamorphic effects in the eastern Petersburg quadrangle. 
sions of Late Cretaceous age; (3) regional thermal metamorphism associated with 90-Ma plutons; (4) Barrovian-type regional metamorphism of biotite to sillimanite grade associated with sill-like intrusions of foliated tonalite of $65 \mathrm{Ma}$ age; and (5) thermal metamorphism in regional-scale aureoles associated with nonfoliated granitic intrusions of $20 \mathrm{Ma}$ age.

The oldest metamorphic episode affected early Late Cretaceous (Cenomanian) rocks (Brew and others, 1984) of the Gravina belt (Berg and others, 1972) and extended eastward to an uncertain limit (fig. 58) within the mainland belt of Brew and others (1984). Poorly to moderately well foliated metagraywackes, semischists, and crenulated phyllites retain few original sedimentary textures. Intermediate-pressure prehnite-pumpellyite to greenschist facies conditions are indicated by mineral assemblages that commonly include chloritewhite mica-zoisite-albite-quartz-opaques, and rarely actinolite.

Low-pressure albite-epidote to hornblendehornfels facies aureoles of 100-110 Ma age intrusions (Lanphere and Eberlein, 1966; M. A. Lanphere, USGS, oral commun., 1983) have overprinted the earlier regional metamorphic fabric. These Alaskatype mafic-ultramafic intrusions and smaller hornblendite and hornblende gabbro bodies are located on northern Lindenberg Peninsula (fig. 58) and within the Gravina belt to the southeast. The metagraywackes within the aureole are poorly foliated and contain granoblastic polygonal and decussate aggregates of (1) actinolite-epidote-quartz-albite-garnetbiotite and (2) hornblende-clinozoisite-quartz-plagioclase-biotite-sphene-magnetite.

The third episode of metamorphism was a regional thermal event associated with granodiorite, tonalite, and quartz diorite intrusions of $90 \mathrm{Ma}$ age (M. A. Lanphere, USGS, written communs., 1981, 1982) This event affected previously metamorphosed Gravina belt rocks on Lindenberg Peninsula, Mitkof, Woronkofski, and Wrangell Islands, along with some mainland rocks west of the Coast Range megalineament. The $90 \mathrm{Ma}$ age plutons are distinguished by Burrell (1984) according to differing texture, mineralogy, form, and other features. Our study shows that the type of aluminosilicate polymorph in aureoles can also distinguish some plutons: andalusite and (or) sillimanite occur in lowpressure hornblende-hornfels aureoles near plutons of predominantly nonfoliated quartz monzonite; kyanite, sillimanite, and andalusite, indicating low to intermediate pressure, occur in aureoles related to concordant intrusions of foliated tonalite. The foliated tonalite bodies contain primary epidote and garnet and are similar to those interpreted by Zen and Hammarstrom (1984) to have crystallized at high pressures.

Aluminosilicate polymorphs are texturally complicated within these aureoles. Mineral assemblages in the low-pressure aureoles locally include coarse sillimanite and (or) relict andalusite along with fibrolite-garnet-biotite-plagioclase-quartz- staurolite-ilmenite. Low- to intermediate-pressure aureoles contain kyanite and coarse sillimanite or kyanite, relict andalusite and coarse sillimanite along with fibrolite, staurolite, garnet, biotite, quartz, plagioclase, and muscovite. Fibrolite is ubiquitous in both low and low- to intermediate-pressure aureoles as syn- to late-kinematic mats of sillimanite needles. Prismatic andalusite-shaped mineral aggregates are present in the schists and gneisses. These aggregates contain intergrown subidioblastic kyanite and staurolite, coarse prismatic sillimanite, and rarely xenomorphic andalusite cores. The aureoles of the easternmost plutons of $90 \mathrm{Ma}$ age in the map area are difficult to separate from the overlapping intermediate-pressure metamorphic belt of the next episode.

An extensive Barrovian-type metamorchic sequence defined by progressive garnet, staurolite, kyanite, and sillimanite isograds is associated with the tonalite sill belt of foliated intrusions of 62-69 Ma age (Gehrels and others, 1983, 1984) (fig. 58). Foliation of the schists and gneisses is parallel to the trend of the metamorphic mineral isograds, which, in turn, are parallel to the foliation within the tonalite intrusions. These relationships indicate syn-metamorphic to post-metamorphic intrusion.

Metamorphic grade increases to the northeast from prehnite-pumpellyite/greenschist facies to sillimanite-zone amphibolite facies. Locally, textures such as deformed crenulation, transposed and disrupted foliation, and shattered porphyroblasts with fragment trains, suggest that one or more deformational, and perhaps metamorphic, episodes may have affected some of these rocks. Typical semipelitic amphibolite-facies schists and gneisses contain quartz-muscovite-oligoclase to andesine plagioclase-biotite-garnet-staurolite \pm kyanite, and rarely potassium feldspar - muscovite - biotite - garnetquartz-plagioclase-ilmenite + sillimanite. The nature of this metamorphic episode is similar to that described by Himmelberg and others (1984a,b; 1985 ) in the Juneau area. The eastern limit of this regional metamorphism is obscured b:r the emplacement of granodiorite plutons of $50 \mathrm{Ma}$ age described by Webster (1984). A regional str'ıctural feature, the Coast Range megalineament, trends nearly parallel to the isograd trend and locally coincides with the sillimanite isograd. Later hydrothermal alteration and mylonitization is lonalized along the megalineament.

The youngest episode is represented $r y$ lowpressure-facies regional-thermal aureoles associated with nonfoliated, miarolitic granitic intrurions of $20 \mathrm{Ma}$ age (M. A. Lanphere, USGS, written commun., 1982). On Etolin, Deer, and Zarembo Islands, in the southeastern part of the Petersburg quadrangle, this poorly documented episode overprints previously metamorphosed Gravina belt rocks with albite-epidote hornfels facies aureoles. 


\section{REFERENCES CITED}

Berg, H. C., Jones, D. L., and Richter, D. H., 1972, Gravina-Nutzotin belt-Tectonic significance of an upper Mesozoic sedimentary and volcanic sequence in southern and southeastern Alaska, in Geological Survey research 1972: U.S. Geological Survey Professional Paper 800-D, p. D1D24.

Brew, D. A., Ovenshine, A. T., Karl, S. M., and Hunt, S. J., 1984, Preliminary reconnaissance geologic map of the Petersburg and parts of the Port Alexander and Sumdum 1:250,000 quadrangles, southeastern Alaska-U.S. Geological Survey Open-File Report $84-405,43$ p., 2 sheets, scale $1: 250,000$.

Burrell, P. D., 1984, Map and table describing the Admiralty-Revillagigedo intrusive belt plutons in the Petersburg 1:250,000 quadrangle, southeastern Alaska-U.S. Geological Survey OpenFile Report 84-171, 6 p., 1 sheet, scale $1: 250,000$.

Gehrels, G. E., Brew, D. A., and Saleeby, J. R., $1983, \mathrm{U}-\mathrm{Pb}$ zircon ages of major intrusive suites in the Coast plutonic-metamorphic complex near Juneau, southeastern Alaska (abs.): Geological Association of Canada, Abstracts with Program, v. 8, p. A26.

Gehrels, G. E., Brew, D. A., and Saleeby, J. R., 1984 , Progress report on $\mathrm{U} / \mathrm{Pb}$ (zircon) geochronologic studies in the Coast plutonic-metamorphic complex east of Juneau, southeastern Alaska, in Reed, K. M., and Bartsch-Winkler, Susan, eds., The United States Geological Survey in Alaska-Accomplishments during 1982: U.S. Geological Survey Circular 939, p. 100-102.

Himmelberg, G. R., Ford, A. B., and Brew, D. A., 1984a, Progressive metamorphism of pelitic rocks in the Juneau area, southeastern Alaska, in Coonrad, W. L., and Elliott, R. L., eds., The United States Geological Survey in Alaska-Accomplishments during 1981: U.S. Geological Survey Circular 868, p. 131-134.

Himmelberg, G. R., Ford, A. B., and Brew, D. A., $1984 \mathrm{~b}$, Reaction isograds in pelitic rocks of the Coast plutonic-metamorphic complex near Juneau, Alaska, in Reed, K. M., and BartschWinkler, Susan, eds., The United States Geological Survey in Alaska-Accomplishments during 1982: U.S. Geological Survey Circular 939, p. 105-108.

Himmelberg, G. R., Ford, A. B., Brew, D. A., and Van Horn, Stephen, 1985, Chemical zonation of garnet in pelitic rocks of the Coast plutonicmetamorphic complex near Juneau, Alaska, in Bartsch-Winkler, Susan, and Reed, K. M., eds., The U.S. Geological Survey in Alaska-Accomplishments during 1983: U.S. Geological Survey Circular 945, p. 91-92.
Lanphere, M. S., and Eberlein, G. D., 1966, Potassium-argon ages of magnetite-bearing ultramafic complexes in southeastern Alaska (abs.): Geological Society of America Special Paper 87, p. 94.

Webster, J. H., 1984, Preliminary report on a large granitic body in the Coast Mountains, northeast Petersburg quadrangle, southeastern Alaska, in Reed, K. M., and Bartsch-Winkler, Susan, eds., The United States Geological Surv y in Alaska -Accomplishments during 1982: U.S. Geological Survey Circular 939, p. 116-11

Zen, E-an, and Hammarstrom, J. M., 1984, Mineralogy and a petrogenetic model for the tonalite pluton at Bushy Point, Revillag:gedo Island, Ketchikan $1^{\circ} \times 2^{\circ}$ quadrangle, southeastern Alaska, in Reed, K. M., and Bartsch-Winkler, Susan, eds., The United States Geological Survey in Alaska-Accomplishments during 1982: U.S. Geological Survey Circular 939, p. 118-123.

Reviewers: Cynthia Dusel-Bacon and A. B. Ford

\section{ULTRAMAFIC BODIES IN TI'E COAST PLUTONIC-METAMORPHIC COMPLEX NEAR SKAGWAY, SOUTHEASTERN ALASKA}

\section{Glen R. Himmelberg, David A. Brew, and Arthur B. Ford}

Previously unknown major exposures of peridotite occur discontinuously along an approximately 30-km-long and 8-km-wide, northwest-trending belt within the Coast plutonic-metamorphic complex in the Atlin A-8 quadrangle (fig. 56). Based upon structure, two groups of ultramafic roc'ss are recognized: tectonized and nontectonized.

The ultramafic rocks with a tectonite fabric occur in at least several 100-200-m-thick layers in a zone of biotite schist, quartzo-feldspathic orthogneiss, and amphibolite, along the northeast margin of the ultramafic belt. The penetrative structures of these ultramafic rocks range from pronounced to weak and are concordant with structures in the schists and gneisses. The ultramafic rocks have been recrystallized to assemblages containing forsterite, tremolite, talc, minor chlorite, and magnetite. Centimeter-scale layers of boudinaged and disrupted chlorite-rich schist are common in the tectonized ultramafic rocks and gash veins of talc are locally present. Protoliths of the tectonized ultramafic rocks are mostly harzburgite with only minor dunite.

Nontectonized ultramafic rocks are peridotite and are broadly scattered along the boundary between areally extensive units of hornblende-plagioclase gneiss (and amphibolite) and hornblendebiotite tonalite. The peridotite intrudss the hornblende-plagioclase gneiss and is intruced by horn- 
blende-biotite tonalite in which the peridotite bodies occur widely as rafts ranging in size from a few meters to several kilometers. Relations with nearby fossiliferous rocks of Middle Triassic and early Late Triassic age (Brew and others, 1985) and lithologic comparison of the tonalite to other dated plutons in the area suggest a time-constraint on peridotite emplacement between the end of the Triassic and about $60 \mathrm{Ma}$. The peridotite is mostly harzburgite with a primary mineral assemblage of olivine (70-85 percent), or thopyroxene (15-30 percent), and chromite (1-3 percent). The peridotite is generally massive and homogeneous, although primary igneous structures are locally present. These are: (1) dunite layers one to several meters thick with aligned chromite "trains" parallel to the layer boundaries; (2) poikilitic wehrlite layers about $1 \mathrm{~m}$ thick with 2-3 cm-size clinopyroxene oikocrysts; and (3) olivine-pyroxene layers one to several centimeters thick with ratio contacts. Hornblende-clinopyroxene-plagioclase and hurnblende-clinopyroxenemagnetite veins and pegmatite dikes cut the peridotite. Individual hornblende and pyroxene crystals in the pegmatite are as long as $30 \mathrm{~cm}$.

In some contact zones of peridotite with hornblende-pyroxene gneiss, the peridotite contains abundant, aligned, and boudinaged, disrupted hornblende-plagioclase gneiss xenoliths several meters in length. Pronounced reaction zones are developed between peridotite and hornblende-plagioclase gneiss xenoliths. These reaction zones consist of dual rinds, each about $4.5 \mathrm{~cm}$ thick, of olivine + tremolite + magnetite against the peridotite and chlorite + actinolite against the hornblende-plagioclase gneiss.

The primary peridotite is generally anhedral granular with gently curved grain boundaries. Degree of recrystallization of the peridotite by the hornblende-biotite tonalite is variable, being related to the size of the peridotite raft enclosed in tonalite and, for the larger peridotite bodies, proximity to the contact with tonalite. Recrystallized assemblages consist mostly of forsterite + talc + tremolite + minor chlorite + magnetite; much of the re- crystallized forsterite is granoblastic polygonal with $120^{\circ}$ grain boundary intersections.

These newly discovered ultramafic bodies are the only known occurrences of ultramafic intrusions in the central part of the Coast plutonic-metamorphic complex. There are numerous Alaskan-type ultramafic bodies that occur from Klukwan to Duke Island in an ultramafic-mafic belt to the west (Taylor, 1967; Brew and Morrell, 1983), b.lt they have rock associations that are different from those of the ultramafic bodies in the Atlin A-8 quadrangle. The Alaskan-type bodies are mostly dunite, olivine clinopyroxenite, hornblende clinopyroxenite, and clinopyroxene hornblendite, whereas the ultramafic bodies in the Atlin A-8 quadrangle ar $\epsilon$ mostly harzburgite.

The relationship of the tectonized and nontectonized ultramafic rocks is uncertain at this time. However, based on similarity of primary roc's types, similarity of recrystallized assemblages, and the variability of tectonite fabric of the ultramafic rocks in the schists, we tentatively believe all the ultramafic rocks are part of the same intrusion and that the tectonite fabric was only locally deroloped.

\section{REFERENCES CITED}

Brew, D. A., and Morrell, R. P., 1983, Intrusive rocks and plutonic belts of southeastern Alaska, USA: Geological Society of America Memoir 159, p. 171-193.

Brew, D. A., Ford, A. B., and Garwin, S. L.: Fossiliferous Middle and(or) Upper Triassic rocks within Coast plutonic-metamorphic complex southeast of Skagway, Alaska, in RartschWinkler, Susan, ed., The United States Geological Survey in Alaska-Accomplishments during 1984: U.S. Geological Survey Circular 9:7, this volume.

Taylor, H. P., Jr., 1967, The zoned ultramafic complexes of southeastern Alaska, in Wyllie, P. J., ed., Ultramafic and related rocks: Ner York, John Wiley, p. 96-118.

Reviewers: R. A. Loney and W. H. Nelson
I thank Kathleen Krafft, Reston, VA, for the final careful reading of this circular, and Katherine Reed and Virginia Shepard, Anchorage, AK, for tactical support in its completion. 


\section{LISTING OF REFERENCES BY SUBJECT MATTER}

\section{EOONOMIC GEOLOGY}

Bedrock mapping of remote areas using medial moraine debris from active glaciers, Mount Hayes and Healy quadrangles; Edward B. Evenson, George C. Stephens, and David E. Detra

Use of stream-sediment insoluble residues in geochemical exploration for carbonate-hosted mineral deposits in the Baird Mountains; Peter F. Folger, Richard J. Goldfarb, El izabeth A. Bailey, Richard M. O'Leary, and Stephen J. Sutley

Preliminary study of lode gold deposits, Seward Peninsula; Bruce M. Gamble, Roger P. Ashley, and William J. Pickthorn

Selected anomalous rock and sediment samples from central and nor thwestern Baird Mountains quadrangle; Susan M. Kar 1, Jeanine M. Schmidt, and Peter F. Folger

Preliminary interpretation of factor analysis of geochemical data from the Healy quadrangle; Thamas D. Light

\section{ENGINEERING GEOLOGY}

New evidence for activity on the Talkeetna segment of the Castle MountainCaribou fault system--The 1984 Sutton ear thquake; John C. Lahr, Robert A. Page, Kent A. Fogleman, and Chr is topher D. Stephens

\section{GENERAL GEOLOGY}

Age of Devonian igneous-arc terranes in the nor thern Mount Hayes quadrangle, eastern Alaska Range; John N.

Aleinikoff and Warren J. Nokleberg

Greenschist-facies metamorphic rocks of the north-central Iditarod quadrangle; Linda M. Angeloni and Marti L. Mi 1 ler

Terrane analysis, nor thern $\mathrm{Br}$ istol Bay region, southwestern Alaska, Stephen E. Box

Early Cretaceous evolution of the northeastern Yukon-Koyukuk Basin, westcentral Alaska; Stephen E. Box, William W. Patton, Jr., and Chr ist ine Carlson

Southeastern Alaska coincident zone; David A. Brew and Arthur B. Ford

1 iferous Middle and (or) Upper Triassic rocks within the Coast plutonicmetamorphic complex southeast of Skagway; David A. Brew, Ar thur B. Ford, and Steven L. Garwin
Polymetamorphism in the eastern Petersburg quadrangle; Susan L. Douglass and David A. Brew

Preliminary study of lode gold deposits, Seward Peninsula; Bruce M. Gamble, Roger P. Ashley, and William J. Pickthorn

Ultramafic bodies in the Coast plutonicmetamorphic complex near Skagrray; Glen R. Himmelberg, David A. Brew, and Arthur B. Ford

Summary of stratigraphy, structure, and metamorphism of Devonian igneous-arc terranes, nor theastern Mount Hayes quadrangle, Eastern Alaska Range; Warren J. Nokleberg and John N. Aleinikoff

Summary of data on the age of the Orca Group; George Plafker, Gerta Keller, Steven W. Nelson, Julie A. Dumoulin, and Marti L. Miller

Summary of the 1984 TACT geologic studies in the nor thern Chugach Mountains and southern Copper River basin; George Plafker, Warren J. Nokleberg, and John S. Lull

\section{GEOCHEMISTRY}

Preliminary results of $\mathrm{Pb}-\mathrm{i}$ sotope analyses of deposits from the Seward P n insula; Stanley E. Church, Jose?h A. Briskey, Maryse H. Delevaux, and Anne P. LeHuray

Bedrock mapping of remote areas using medial moraine debris from active glaciers, Mount Hayes and Healy quadrangles; Edward B. Evenson, Grorge C. Stephens, and David E. Detra

Use of stream-sediment insoluble rasidues in geochemical exploration for carbonate-hosted mineral deporits in Mountains; Peter F. Folger Richard J. Goldfarb, Elizabeth A. Bailey, Richard M. O'Leary, and Stephen J. Sutley

Ultramafic bodies in the Coast plutonicmetamorphic complex near Skagway; Glen R. Himmelberg, David A. Brew, and Arthur B. Ford

Selected anamalous rock and sediment samples from central and northwestern Baird Mountains quadrangle; Sisan M. Kar 1, Jean ine M. Schmidt, and Peter F. Folger

Preliminary interpretation of factor analysis of geochemical data fran the Healy quadrangle; T.D. Light 


\section{REFERENCES BY SUBJECT--continued}

Page

GEOCHRONOLOGY/PALEOMAGNETISM

Are of Devonian igneous-arc terranes in the northern Mount Hayes quadrangle, eastern Alaska Ranse; John N. Aleinikoff and Warren J. Nokleberg

Paleamagnetism of sedimentary rocks in the Prince William and Yakutat terranes; Jack W. Hi llhouse and C. Sherman Gromme

Summary of data on the age of the Orca Group; George Plafker, Gerta Keller, Steven W. Nelson, Julie A. Dumoul in, and Merti L. Miller

\section{GEOPHYS ICS}

Gravity lows may indicate thick Pleistocene deposits beneath Glacial Lake Noatak; David F. Barnes

Gravity and magnetic model of part of the 1984 TACT 1 ine, Chugach Mountains and southern Copper River basin; David L. Campbell and David F. Barnes minary results of TACT 1984 seismicrefraction survey of southern Alaska; Gary S. Fuis, Elizabeth L. Ambos, Walter D. Mooney, Robert A. Page, and David L. Campbell

Paleamagnetism of sedimentary rocks in the Prince William and Yakutat terranes; Jack W. Hillhouse and C. Sherman Gromms

New evidence for activity of the Talkeetna segment of the Castle MountainCaribou fault system--The 1984 Sutton ear thquake; John C. Lahr, Robert A. Page, Kent A. Fogleman, and Chr is topher D. Stephens

Seismicity in southern Alaska, October 1983-September 1984; Chr is topher D. Stephens, Kent A. Fogleman, John C. Lahr, and Robert A. Page

\section{MARINE GEOLOGY}

Reconnaissance hydrology and suspended sediment analys is, Turnagain Arm estuary, Upper Cook Inlet; Susan

Bartsch-Winkler, Richard P. Enanuel, and Gary R. Winkler

\section{PALEONTOLOGY/PALEOBOTANY}

Fossil iferous Middle and (or) Upper Triassic rocks within Coast plutonicmetamorphic complex southeast of Skagway; David A. Brew, Ar thur B. Ford, and Steven L. Garwin

Early Pennsylvanian conodonts from the Strelna Formation, Chit ina Valley area; George Plafker, Ani ta G. Har r is and Kather ine M. Reed
Summary of data on the age of the Orca Group; George Plafker, Gerta Keller, Steven W. Nelson, Julie A. Dumoulin, and Marti L. Miller

PETROLOGY, IGNEOUS

Ultramafic bodies in the Coast plutonicmetamorphic complex near Skagway; Glen R. Himmelberg, David A. Brew, and Arthur B. Ford

Ophiolitic ultramafic rocks of the Jade Mountains-Cosmos Hills area, southwestern Brooks Range, Robert A. Loroy and Glen R. Himmelberg

PETROLOGY, METAMORPHIC

Polymetamorphism in the eastern Petersbirg quadrangle; Susan L. Douglass and David A. Brew

Ultramafic bodies in the Coast plutonicmetamorphic complex near Skagway; Glen R. Himmelberg, David A. Brew, and Arthur B. Ford

Ophiolitic ultramafic rocks of the Jade Mountains-Cosmos Hills area, south-western Brooks Range; Rober $t$ A. Loney and Glen R. Himmelberg

Preliminary study of shear sense in myloni tes, eastern Ray Mountains, Tanans quadrangle; Ronny T. Miyaoka and James H. Dover

\section{QUATERNARY GEOLOGY}

Gravity lows may indicate thick Pleistocene deposits beneath Glacial Lake Noatak; David F. Barnes

Bedrock mapping of remote areas using medial moraine debris from active glaciers, Mount Hayes and Healy quadrangles; Edward B. Evenson, George C. Stephens, and David E. Detra

Late Quaternary glaciation of the Pavlof Bay and Port Moller areas, Alaska Peninsula; Florence $R$. Weber

\section{SEISYOLOGY}

New evidence for activity of the Talkeetna segment of the Castle MountainCaribou fault system--The 1984 Sutton ear thquake; John C. Lahr, Robert A. Page, Kent A. Fogleman, and Chr istopher D. Stephens

Seismicity in southern Alaska, October 1983-September 1984; Chr istopher D. Stephens, Kent A. Fogleman, John C. Lahr, and Robert A. Page 


\section{STRATIGRAPHY/SEDIMENTOLOGY}

Age of Devonian igneous-arc terranes in the northern Mount Hayes quadrangle, eastern Alaska Range; John N. Aleinikoff and Warren J. Nokleber:

Terrane analysis, nor thern $\mathrm{Br}$ istol Bay region, southwestern Alaska; Stephen E. Box

Geologic setting of high-pressure metamorphic rocks, Cape Newenham area, southwestern Alaska; Stephen E. Box

Early Cretaceous evolution of the northeastern Yukon-Koyukuk Bas in, west-central Alaska; Stephen E. Box, William W. Patton, Jr., and Chr istine Carlson

Foss il i ferous Middle and (or) Upper Triassic rocks within coast plutonicmetamorphic complex southeast of Skagway; David A. Brew, Ar thur B. Ford, and Steven L. Garwin

Sedimentology of meandering-stream cycles in the upper Ear Peak Member, Kanayut Conglomerate, central Brooks Range; Thomas E. Moore and Tor H. Nilsen

Summary of stratigraphy, structure, and metamorphism of Devonian igneous-arc terranes, nor theastern Mount Hayes quadrangle, Eastern Alaska Range; Warren J. Nokleberg and John $\mathrm{H}$. Aleinikof $f$

Early Pennsylvanian conodonts from the Strelna Formation, Chit ina Valley area; George Plafker, Anita G. Harr is and Katherine $M$. Reed

Summary of data on the age of the Orca Group; George Plafker, Gerta Keller, Steven W. Nelson, Julie A. Dumoulin, and Marti L. Miller

\section{STRUCTURAL GEOLOGY/TECTONICS}

Age of Devonian igneous-arc terranes in the nor thern Mount Hayes quadrangle, eastern Alaska Range; John N. Aleinikoff and Warren J. Nokelberg

Gravity lows may indicate thick Pleistocene deposits beneath Glacial Lake Noatak; David F. Barnes

Terrane analysis, nor thern Bristol Bay region, southwestern Alaska; Stephen E. Box

Geologic setting of high-pressure metamorphic rocks, Cape Newenham area, sou thwestern Alaska; Stephen E. Box
Early Cretaceous evolution of the northeastern Yukon-Koyukuk Basin, westcentral Alaska; Stephen E. Box, William W. Patton, Jr., and Chr istine Carlson

Southeastern Alaska coincident zon?; David A. Brew and Arthur B. Ford

Foss 11 i ferous Middle and (or) Upper Triassic rocks within Coast plutonicmetamorphic complex southeast of Skazway; David A. Brew, Ar thur B. Ford, and Steven L. Garwin

Gravity and masnetic model of part of the 1984 TACT line, Chugach Mountains and southern Copper River basin; David L. Campbell and David F. Barnes

Preliminary results of TACT 1984 seismicrefraction survey of southern Alaska; Gary S. Fuis, Elizabeth L. Ambos, Walter D. Mooney, Robert A. Fage, and David L. Campbe 11

Ultramafic bodies in the coast plutonicmetamorphic complex near Skagway; Glen R. Himmelberg, David A. Brew, and Ar thur B. Ford

New evidence for activity of the Talkeetna segment of the Castle MountainCaribou fault system--The 1984 Sutton ear thquake; John C. Lahr, Rokert A. Page, Kent A. Fogleman, and Chr is topher D. Stephens

Preliminary study of shear sense in myloni tes, eastern Ray Mountains, Tanana quadrangle; Ronny T. Miyaoka and James H. Dover

Summary of stratigraphy, structure, and metamorphism of Devonian ignenus-arc terranes, nor theastern Mount Hayes quadrangle, Eastern Alaska Renge; Warren J. Noklebers and John $\mathrm{H}$. Aleinikof $f$

Summary of the 1984 TACT geologic studies in the northern Chugach Mountains and southern Copper River bas in; George Plafker, Warren J. Nokleberg, and John S. Lull

Seismicity in southern Alaska, October 1983-September 1984; Chr istopher D. Stephens, Kent A. Fogleman, John C. Lahr, and Robert A. Page

VOLCANOLOGY

Early Cretaceous evolution of the nor theastern Yukon-Koyukuk Basin, west-central Alaska; Stephen E. Box, William W. Patton, Jr., and Cir istine Carlson 


\section{AUTHORS}

Aleinikoff, John N.........44, 46

Ambos, Elizabeth L...........56

Ange lon i, Linda M.............19

Ashley, Roger P.............27

Bailey, El i zabeth A............5

Barnes, David F............. 52

Bartsch-Winkler, Susan.........49

Box, Stephen E........21, 32, 37

Brew, David A.......82, 86, 89, 92

Briskey, Joseph A............24

Campbell, David L..........52, 56

Carlson, Chr istine...........21

Church, Stanley E............24

Delevaux, Maryse H............24

Detra, David E..............55

Douglass, Susan L.............89

Dover, James H.............29

Dumoulin, Julie A............74

Emanue 1, Richard P............49

Evenson, Edward B............55

Fogleman, Kent A........662, 79

Folger, Peter F............ 8,8

Ford, Arthur B........82, 86, 92

Fu is, Gary S................56

Gamble, Bruce M..............27

Garwin, Steven L..............86

Goldfarb, Richard J............5

Gromme, C. Sherman...........60

Harr is, Anita G...............71

Hillhouse, John W...........60

Himme lberg, Glen R.........13, 92
Kar 1, Susan M................

Keller, Gerta...............74

Lahr, John C...........62, 79

LeHuray, Anne P.............24

Light, Thamas D..............64

Loney, Robert A.............13

Lull, John S...............76

Miller, Marti L...........19, 74

Mi yaoka, Ronny T............29

Mooney, Walter D................56

Moore, Thamas E..............15

Nelson, Steven W.............74

Nilsen, Tor H...............15

Nokleberg, Warren J.....44, 66, 76

O'Leary, Ri chard M...........5

Page, Robert A........56, 62, 79

Patton, William W., Jr.........21

Pickthorn, William J...........27

Plafker, George.........71, 74, 76

Reed, Kather ine M...........71

Schmi dt, Jeani ne M............8

Stephens, Chr istopher D.....62, 79

Stephens, George C..............55

Sut ley, Stephen J.............5

Weber, Florence R...........44

Winkler, Gary R.............49 


